\title{
Prescription of drugs in general practice : longitudinal changes and influence of a prescription formulary
}

Citation for published version (APA):

Peeters-Udding, L. M. (2000). Prescription of drugs in general practice : longitudinal changes and influence of a prescription formulary. [Doctoral Thesis, Maastricht University]. Universiteit Maastricht. https://doi.org/10.26481/dis.20001005/p

Document status and date:

Published: 01/01/2000

DOI:

10.26481/dis.20001005Ip

Document Version:

Publisher's PDF, also known as Version of record

\section{Please check the document version of this publication:}

- A submitted manuscript is the version of the article upon submission and before peer-review. There can be important differences between the submitted version and the official published version of record.

People interested in the research are advised to contact the author for the final version of the publication, or visit the DOI to the publisher's website.

- The final author version and the galley proof are versions of the publication after peer review.

- The final published version features the final layout of the paper including the volume, issue and page numbers.

Link to publication

\footnotetext{
General rights rights.

- You may freely distribute the URL identifying the publication in the public portal. please follow below link for the End User Agreement:

www.umlib.nl/taverne-license

Take down policy

If you believe that this document breaches copyright please contact us at:

repository@maastrichtuniversity.nl

providing details and we will investigate your claim.
}

Copyright and moral rights for the publications made accessible in the public portal are retained by the authors and/or other copyright owners and it is a condition of accessing publications that users recognise and abide by the legal requirements associated with these

- Users may download and print one copy of any publication from the public portal for the purpose of private study or research.

- You may not further distribute the material or use it for any profit-making activity or commercial gain

If the publication is distributed under the terms of Article $25 \mathrm{fa}$ of the Dutch Copyright Act, indicated by the "Taverne" license above, 


\title{
PRESCRIPTION OF DRUGS IN GENERAL PRACTICE
}

\author{
LONGITUDINAL CHANGES AND INFLUENCE OF
}

A PRESCRIPTION FORMULARY

L.M. Peeters - Udding 


\section{(c) L.M.Peeters-Udding}

Niets van deze uitgave mag worden vermenigvuldigd en/of openbaar gemaakt door middel van druk, fotokopie, microfilm of op welke andere wijze dan ook, zonder voorafgaande schriftelijke toestemming van de auteur.

ontwerp van de omslag: (O mevr.dr.J.A.Brombacher, New York (USA).

ISBN $90-9014117-0$ 




\title{
PRESCRIPTION OF DRUGS IN GENERAL PRACTICE
}

\author{
LONGITUDINAL CHANGES AND INFLUENCE OF \\ A PRESCRIPTION FORMULARY
}

\section{PROEFSCHRIFT}

ter verkrijging van de graad van doctor aan de Universiteit Maastricht,

op gezag van de Rector Magnificus, Prof. dr. A.C. Nieuwenhuijzen Kruseman, volgens het besluit van het College van Decanen,

in het openbaar te verdedigen

op donderdag 5 oktober 2000 om 14.00 uur

door

Lucretia Magdalena Peeters - Udding 


\section{Promotores:}

Prof. dr. J.A. Knottnerus

Prof. dr. P.J. Brombacher

\section{Beoordelingscommissie:}

Prof. dr. P. Pop (voorzitter)

Prof. dr. M.P.M. van Dieijen - Visser

Dr. R. Janknegt (Maaslandziekenhuis, Sittard)

Prof. dr. B. Meyboom - de Jong (Rijksuniversiteit Groningen)

Dr. W.P.M. Vierhout Academy of Sciences (KNAW). 
Dankzij Jo. 



\section{CONTENTS}

I. General introduction. . . . . . . . . . . . . . . . . 1

II. Prescribing drugs in general practice. ............. 9 A review of the literature.

III. Outline of the investigation. Study objectives and setting.

IV. Longitudinal changes in 'unbound' drug prescription.

V. Long term influence of formulary-bound drug prescription. . 165 Comparative investigation on the influence of a regional limited formulary on drug prescription in general practice.

VI. Evaluation of longitudinal changes in drug prescription. 213 A qualitative study on prescribing in general practice.

VII. Influence of a prescription formulary on cost of medication. . 239

VIII. General discussion arid conclusions. . . . . . . . . . 259

Summary. ........................ 267

Samenvatting. ......................... 275

Dankwoord ........................... 285

Curriculum vitae . . . . . . . . . . . . . . . . . . . 289 
ACE

ATC

$B C G$

BNF

CE

CME

CNS

DDD

EDL

$E Z$

GI

GP

ICPC

IWG

JNC

LRTI

MDW

MI

MR

NAMCS

NCE

NHG

NSAID

$\mathrm{PC}$

PHC

PTAM

RCGP

SNRI

SSRI

UK

UM

US

vWs

WVC angiotensine converting enzyme

anatomical chemical therapeutical classification

Boston Consulting Group

British National Formulary

cost effectiveness

continuing medical education

central nervous system

defined daily dose

Essential Drug List

Ministerie van Economische Zaken

(Ministry of Economic Affairs)

gastro intestinal

general practitioner

International Classification of Primary Care

interdepartementale werkgroup (VWS en EZ)

Joint National Committee

lower respiratory tract infections

Marktwerking, Deregulering and Wetgevingskwaliteit

myocardial infarction

medical representative

National Ambulatory Medical Care Survey

new chemical entity

Nederlands Huisartsen Genootschap (Dutch College of General

Practitioners)

non-steroidal anti-inflammatory drugs

pharmaceutical company

Primary Health Care

pharmaco-therapeutical audit meetings

Royal College of General Practitioners

serotonin-norepinephrine re-uptake inhibitor

selective serotonine re-uptake inhibitor

United Kingdom of Great Britain

University of Maastricht

United States of America

Ministerie van Volksgezondheid, Welzijn en Sport

(Ministry of Public Health, Public Welfare and Sports)

Ministerie van Welzijn, Volksgezondheid en Cultuur

(Ministry of Public Welfare, Public Health and Culture) 


CHAPTER I

\section{GENERAL INTRODUCTION}



Twenty years of experience as a community pharmacist made the author of this thesis curious about the longitudinal changes she thought to recognise in prescription behaviour of general practitioners and hospital consultants. In spite of increasing efforts from the side of the government to decrease the ever growing expenditures for pharmaceutical care, there seemed to be a strong counterforce that somehow obstructed the implementation in everyday practice of 'good prescribing habits', notwithstanding the sympathetic ear with all who were concerned with prescribing and delivering medicines for all the efforts made by the other parties mentioned. Some governmental efforts (figure, ref. 137) that influenced the management of pharmacists in the last two decades were in a chronological order:

1982: - price act, withdrawn in 1993, judged contrary to European directives;

- delisting for reimbursement of cheaper drugs for common diseases. As a result increasing prescription of more expensive drugs for common diseases was observed;

1982: - limited out-of-pocket payment of two and a half dutch guilders for every prescription. This resulted in greater prescription volumes. The measure was cancelled in 1990;

- introduction of the "Farmaceutisch Kompas" (Pharmaceutical Precept), a yearly renewed textbook with a complete survey of all prescription drugs on the market, with a pharmaco-therapeutic judgement and a survey of prices; free of charge available for health care providers.

1988: - change from an annual fee per registered NHS-patient for pharmacists to a fee per prescription;

- limiting prescriptions to a length of 90 days for long term treatment and to 30 days for all other treatments;

1989: - Omni Partijen Accoord, a gentlemen's agreement between pharmaceutical companies, pharmaceutical wholesalers, pharmacists and the government about bonuses and discounts; withdrawn in 1990;

1991: - reshuffle of the delisted drugs from 1982;

- sharpening of the prescription limits to 15 days for first treatments:

- Drug Reimbursement System: dividing all prescription drugs according to ATC category in clusters of mutually interchangeable drugs with one reimbursement limit set per cluster;

- introduction of Pharmaco-Therapeutical Audit Meetings (PTAM or FTO) for general practitioners and community pharmacists;

1993: - delisting for reimbursement of homeopathic and anthroposophic treatments;

- closure of supplement 6 of the Drug Reimbursement System resulting in 
(temporary) out-of-pocket payment for some new drugs:

1994: - deleting reimbursement for many self care drugs and dietary products;

1996: - Drug Prices Act first and second stage; the upper limits of prices for orally administered drugs, suppositories and insulin preparations were fixed at the average price levels of neighbouring countries: Germany, France, Belgium and the United Kingdom;

1997: - Drug Prices Act third and fourth stage; the upper limits of prices for inhalers, ear-, eye- and nose-drops, ointments and creams, solutions and suspensions, powders, granulates and enemas were fixed at the average price levels of neighbouring countries: Germany, France, Belgium and the United Kingdom;

- limited introduction of new drugs from supplement 6;

1998: - introduction of the "claw-back" on declarations of pharmacists: withholding in advance an assessed amount of the reimbursement for pharmacists in order to pass on part of the rebates to the prices of drugs;

1999: - governmental financial support for "proeftuinen" (experimental regions): an effort for health insurance companies, physicians and pharmacists in primary and secondary care to develop and to implement bottom-up plans for the improvement of pharmaceutical care;

- deleting reimbursement for short term use of self care drugs that are supplied on prescription.

Part of these measures involved only cost and sometimes also quality of prescribing. In the mean time with the same objectives a number of reports, some by government order, have been published by an equal number of committees and working groups in order to advise on the improvement of efficiency/costs proportions in pharmaceutical care and to discover bottlenecks in the legislation that might prevent improvements (cf. Dekker (138), Dunning (117), IWG (Interdepartementale Werkgroep, 139), MDW (Marktwerking, Deregulering en Wetgevingskwaliteit, 140), Adviesgroep Kwaliteit (76), BCG (Boston Consulting Group, 141) and Raad voor de Volksgezondheid en Zorg $(151,162)$ ).

Reviewing professional literature revealed that similar problems had been pointed out by many investigators all over the western world $(19,34,42,55,125,127,142$, 157). The key objectives were promotion of rational and consistent prescription policy, use of prescription formularies, continuing professional education and feedback on prescription behaviour and reduction of costs. Rational prescribing habits were, as the author suspected, likely to play a major role in both the quality of prescribing and decreasing the costs of pharmaceutical aid. Since the author's 
own experience was that changes in prescribing patterns show up on the long run it seemed sensible to investigate general practitioners' prescribing habits over a longer period of time by

- $\quad$ studying longitudinal changes and stability of prescription patterns;

- registration of influences on prescription;

- comparing and registration of differences in prescribing habits, motives and costs between two groups of GPs, viz. a first group without any agreements on prescription and a second group with a successful history of formulary based prescription behaviour;

- retrospective evaluation of their personal prescription behaviour with all individual GPs.

The computerisation of prescriptions in the Netherlands is predominantly maintained in community pharmacies. Thus the obvious scope of the study had to be general practitioners and community pharmacies. Conferring on this matter with the University Department of General Practice in Maastricht, first a reference group of GPs was found where no agreements of any kind ever had been made about preferable prescriptions. Secondary, an audit group was chosen with more than a decade history use of a prescription formulary and working with the same computer system as the reference group. The kind cooperation we needed so much was easily granted to us by all GPs and pharmacists.

We considered that a research program that could be performed with simple means which are available to a large majority of community pharmacists in western countries, had the best chance of easily being copied by other primary health care groups. So we fundamentally chose to work with the following aids and resources: a community pharmacy computer system with a history of prescriptions over several years, a personal computer system with a text processor and a spread sheet program to retrieve and process the prescription data. We decided to use national guidelines as published in professional literature and the regional formulary agreements of the audit group to assess the quality of prescribing habits. Moreover, our interest included the personal retrospective evaluation of their prescription behaviour by the general practitioners themselves. Finally we decided to use computerised cost declarations data which can be obtained from a national health service insurance company by any Dutch pharmacotherapeutical meeting group to study the inherent economical aspects of prescribing.

This thesis, reporting the findings of our study, is structured as follows:

- A review of the literature is reported in chapter II with an extensive survey 
in diagram form in the tables $2.1-2.5$ and a short summary in text;

- In chapter III an outline of our investigation is presented with the description and motivation of the choices and selections we made concerning the groups of GPs, the categories of drugs, time span, pharmacies, computer systems, PTAMs, data collection and-processing, compliance of prescription with guidelines and formularies, costs effects and retrospective evaluation of prescription behaviour;

- The longitudinal changes and stabilities we found in the tunbound prescription' group of GPs are discussed and graphically presented (figs. 4.1-7. $\mathrm{N} / \mathrm{AC} / \mathrm{AD} / \mathrm{B} / \mathrm{Ca} / \mathrm{Ch}$ ) in chapter $\mathrm{IV}$, as well as the compliance with the national guidelines;

- In chapter V comparative data and the graphical diagrams of the formularybound' group of GPs are discussed as well as our findings on the differences between the patterns and the compliance with national viz. formulary guidelines as we found them in and between both groups;

- The retrospective evaluation in structured oral interviews with the individual GPs (chapter Vl) means to elucidate aware and unaware reasons for the changes and stability as had been observed in each GP's individual prescription pattern from the passed three and a half year;

- After collection of the data on costs from the regional health insurance companies we drew up a report about our findings in chapter VII;

- The general conclusions from our study are discussed and some recommendations for future investigation are presented in chapter VIII.

References: cf. general reference list (chapter II). 
fig.1.1 Development of the Dutch phamaceutical market from 1987 - 1996 wth indication of major government interventions.

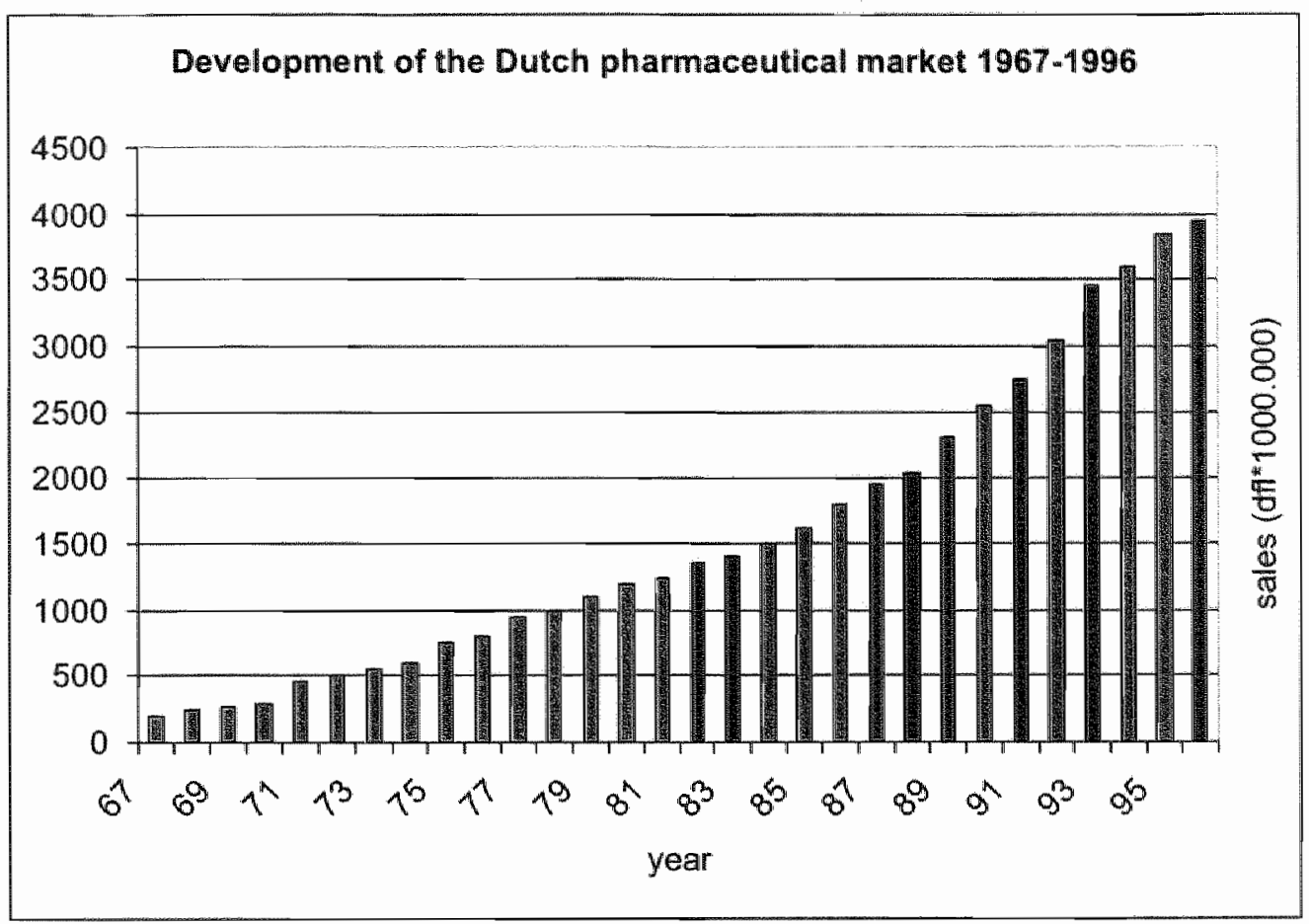

IMS dertig jaar in Nederland, Statistisch Jaaroverzicht 1996, IMS, Den Haag, NL. (ref.137)

Major government interventions 1967 - 1996 (marked red):

1982: -dellisting for reimbursement of cheaper drugs for common diseases.

1983: - Introduction of the "Farmaceutisch Kompas" (Pharmaceutical Compass), limited out-of-pocket payment of two and a haff dutch guilders for every prescription.

1987: -Dekker Report (138)

1988: -change from an annual fee per registered NHS-patient for phamacists to a foe per prescription

1989: - Omni Partjien Accoord

1991: - Drug Reimbursement System

1993: - closure of supplement 6 of the Drug Reimbursement System

1996: - Drug Prices Act 

CHAPTER II

PRESCRIBING DRUGS IN GENERAL PRACTICE

A REVIEW OF THE LITERATURE 
Introduction. In the past decades many studies have been published on the prescription behaviour of general practitioners. Various kinds of influences on prescription of drugs in general practice and in hospital settings have been studied and the results of several interventions aiming at improved prescribing behaviour have been reported. In recent decades specific potent drugs have been developed by which biochemical reactions in the human being could be influenced in a more or less specific way. This promoted the development of pharmaceutical industry and legislation about the registration and distribution of drugs, central pharmacies, and the possibility for GPs in rich western countries to choose from a broad variety of safe and effective drugs with relatively predictable side effects. At first sight it might be expected that this would lead to dynamic prescription behaviour with longitudinal changes in pace with developments in medical and natural science, taught in continuous (post)-academic professional training programs. However, prescribing drugs as a part of medical treatment is not only dependent of patho-physiological knowledge. Important social and emotional factors cannot be neglected and this is also true for economic aspects.

For an account of the state of affairs regarding changing prescribing behaviour of general practitioners we searched via Medline over the past ten years using appropriate key words ${ }^{1}$ ), some Dutch journals and other references. Via Medline we found 450 records of which we judged 102 to be suitable for this chapter. The criteria for suitability were: concerning prescription of medication, relevant for primary care setting, low costs, low efforts, simple, practical.

Reading and searching the literature within this main focus we found at least the following twenty four distinguishing items mentioned to be connected with prescribing:

- concerning the GPs (table 2.1): age, gender, attitude, own experience with drugs, inter-doctor variation, routine behaviour and (un)awareness in prescribing;

- pharmaceutical aspects (table 2.2): efficacy and safety of drugs, introduction of new drugs, listing/deleting and reimbursement, cost of drugs;

- formularies and the art of prescribing (table 2.3): formulary, electronic /com-

key words." aware, attitude, behaviour, change, choice, compared, decision-making. different drugs, drug, evaluation, formulary/ies, general practitioner, individuality, industry/ies, infiuence, longitudinal studies, medical audit, new drug, patterns, pharmaceutical company/ies, pharmacy and therapeutics committee, physicians, - family, prescription, quality, rational, reason, retrospective, unaware. 
puterised prescribing system, discomfort in prescribing, feedback on prescription figures, specialist's prescriptions;

- influence of professional education and information (table 2.4): evidence based medicine, medical audit, guidelines and protocols, pharmaceutical industry, pharmacists;

- concerning the patients (table 2.5): age of patients, patients' demands, satisfaction and complaints.

In the following paragraphs these items will be systematically discussed as we found them in professional literature, mainly of the past decade.

General practitioners and their practices (table 2.1). Only a few sometimes contradictory papers have been published stating that age either has no influence on prescription (179) or that younger doctors are more susceptible to intervention $(59,79)$ and tend to prescribe less than their older colleagues (103). Influence of age of physicians on prescription behaviour often seemed to be of limited importance. More agreement was found between investigators on the influence of gender. It was generally concluded that male GPs easily prescribed more drugs than their female colleagues $(100,179)$ of whom only $9 \%$ were heavy prescribers (103).

A physician's attitude towards pharmacotherapy had more influence. Late prescribers shared a restrictive attitude and often showed a tendency to lower diagnostic activity per patient (100). Moreover, adverse drug reactions were often incompletely mentioned due to a certain degree of unawareness of reporting $(100,105)$. Finally the experience/duration of practical activity as a GP did not appear to influence prescription behaviour although high prescribers in general were found in larger practices where more patients per day were seen and more services performed (179). On the contrary, the introduction of new drugs was latest by GPs showing a tendency to lower diagnostic activity per patient (100). Personal experience played a role but thoughtless copying of prescriptions as part of routine behaviour has also been observed (68).

As expected professional education of GPs influenced prescribing especially when active interventions such as visits of local opinion leaders and the use of questionnaires were applied $(92,93,96,105)$. Highest response rates were recorded by trainers, principals and younger doctors (26). In these groups support was also found for continuing professional education and reaccreditation. Prescribing practices were among the most popular subjects for courses to be led by professional experts (109). It might be concluded that analysing the prescription behaviour of GPs and how this depends on either conscious or even sub-conscious influences would be a prerequisite for achieving more 
rational prescribing.

Pharmaceutical aspects (table 2.2). It was hardly surprising that more publications were found on several aspects of drugs than about the characteristics of prescribers. Although efficacy and safety of drugs are considered to be of paramount importance this was too often not the leading principle in drug selection. Awareness of drug effects was replaced by routine behaviour and repeatedly lacking evidence of effectiveness was unlikely to change doctor's prescribing (13). To explain the risks of such a policy for both patients $(27,111)$ and doctors (6) required extensive educational intervention (47). Nevertheless, no objective medical need could explain the heavy prescribing of new drugs as occurred about ten years ago in England as has been investigated afterwards (103). The investigators reviewed dispensing data over a period of five years and reported more than half a million treatments with new drugs by 28402 GPs. It was concluded that it seemed not prudent to expose so many people to potential risks inherent to the prescription of new drugs. Moreover, the response rate to requests to GPs to supply post-marketing data on new drugs had been falling which might induce inappropriate prescription. In line with these observations, other authors (111) report on evaluation of appropriateness of prescription of a new antibiotic. They judged that taking into account indication, effectiveness and price, only $25 \%$ of prescriptions were appropriate indicating that prescribing was less than optimal with potential consequences of resistant bacterial strains. Attention was also drawn to the necessity to report on adverse drug reactions (105). However, from a population of 350 GPs who were invited to react, only $207(59 \%)$ responded to questionnaires. As a reason for this poor result they found lack of awareness of how and when to report, and too many adverse reactions were incorrectly judged clinically negligible. Still another source of incorrect prescription was pressure by patients who when insisting often got what they wanted (14). Relevant risk factors were sometimes ignored even though they were understood because the risk assessment involved was too psychologically complex to be performed intuitively (21). Information about risks to individual patients might be more effective than providing evidence for lack of effectiveness of specific drugs (13). A conclusion is that improvement of pharmacovigilance appears to be necessary.

The introduction of new drugs as a result of progress in pharmacotherapy was sometimes remarkably inhibited by the policy of improving drug therapy by introduction of a limited formulary. Drug formularies limiting the number of new drugs caused a discussion on the use of generic names for new chemical entities instead of brand names (101). Again, insufficient knowledge on adverse 
effects (105) and disproportionate increase of costs (104) had negative effects on the reception of new drugs. On the other hand some authors (102) reported an increasing prescription of newly available drugs (ACE-inhibitors, broad spectrum antibiotics and $\mathrm{H} 2$-receptor antagonists) which seemed to be greater than could be accounted for by an increase in patients with specific indications for these drugs. It was concluded (100) that the diffusion of new drugs in general practice appeared to be dependent on both physician and drug characteristics.

Last but not least prescription of drugs has always been under economic pressure. Governments and health insurance companies aiming at cost reduction constantly try to influence prescription behaviour. The field is rather complex. A study in more than 800 general practices in England showed that a clear picture on costs could hardly be obtained because of considerable variations between practices and over time $(91,103)$. Nevertheless, much has been investigated and many studies with varying results and suggestions have been published. Drug expenditures in general practice have been influenced and often increased by hospital-initiated prescriptions $(22,33,93,12)$ where medical consultants often are engaged in trials with the newest drugs. In an academic centre a cost reduction of $48 \%$ could be achieved by simply changing antiemetic medication ( 90$)$. On the other hand introducing 'academic' procedures for the management of hyperlipidaemia in 134 primary care centres in Sweden increased overall costs because of earlier prescription of lipid-lowering drugs (93). Also trends in prescription and the determinants of these trends have been investigated such as changes connected with increasing ageing of the population. Introduction of a drug prescription program for elderly patients showed a threefold increase of expenditures over seven years of which $43 \%$ was due to the introduction of new drugs, $24 \%$ to increased age-specific utilisation rates of 'old" drugs, $21 \%$ due to increased prices of drugs and $14 \%$ to the increased number of the elderly population (104). Although to some extent this might be characterised as progress in medicine, inappropriate use of drugs leading to a sometimes considerable waste of money $(102,111)$ should be avoided. For this reason suitably informing GPs not only on therapeutic properties of drugs but also on financial aspects is necessary. It has been reported that many physicians hardly were aware of the cost of drugs they prescribed $(66,136)$. Medical education is indispensable in order to develop sensible prescription strategies especially for those diseases which generate the majority of increased drugs expenditures such as cardiovascular, gastrointestinal and central nervous system disorders (308). When composing a formulary for general practice including information on cost of drugs next to pharmacological 
information is important. However, this ought to be done carefully because too much attention for economic aspects might undermine the credibility of the formulary (17). A high level of concern among GPs regarding possible adverse effects of financial pressures upon medical decisions has been reported (67) notwithstanding genuine interest in economic aspects of pharmacotherapy $(24,66)$.

Formularies and the art of prescribing (table 2.3). A major problem in prescribing is to select the "drug of choice" from a large list of chemical entities in the same ATC-category. Medical societies in several countries recognised this problem and published guidelines for the treatment including drug therapy for a number of common diseases $(47,71,97,215)$. It appeared that too much variety of selection from a large formulary prevented the building up of experience and expertise of the GPs and adjacent educational intervention was needed (47). Too many drugs, lack of transparency on the market and producer-oriented drug information caused poor prescribing and inhibited the acceptance of a European Formulary (27). On the other hand limited lists have been regarded as a major hurdle for brand name drug companies (101) and as objections for developments in pharmacotherapy and introduction of new drugs $(99,115)$. E.g. the conservative attitude of groups of British GPs in prescribing 'older' generics and avoiding newer drugs although perhaps saving money might work against the progress of health care (98). Another aspect to be considered was that many GPs to some extent objected against the introduction of national formularies which they regarded as undemanded interference with their professional independence $(16,216)$. Nevertheless good experience was reported with some more limited formularies $(97,155)$ which had been composed in close cooperation between local groups of GPs and pharmacists $(11,155)$. Influence by pharmaceutical companies was restricted as this often caused discomfort to prescribers (108). Unawareness of prescribing $(107,110)$ could be diminished by providing the formulary ready at hand in the computer at the doctor's desk (18). This also could help in discussions with patients who sometimes insisted on prescription of actually inappropriate medication $(11,13,10)$. However, maintaining the formulary in line with the 'state of the art' is essential and the influence of medical specialists' prescription thas to be considered $(71,22,63)$. Community pharmacists organising pharmaco-therapeutic audit meetings (PTAM) could help in reviewing long term medication and improving prescription policy by adequate feed-back information (11) and professional shifting of industrial information. 
Influence of education and information (table 2.4). Among the many influences on prescription behaviour of GPs continuing professional education and information is indispensable. This was generally recognised although many physicians admitted that too often prescribing was a matter of routine lacking of sufficient awareness $(181,110,107)$. Suggestions for changing prescription behaviour should be resulting from evidence based medicine but even then were often hesitatingly accepted $(94,102,49)$. Improvements could be expected and have been reported from regular PTAMs where structured information was provided and mutual experiences with colleagues could be exchanged $(97,71,11,110,18,155)$. Accordingly much interest for audit meetings providing unbiassed information was pronounced especially if these aimed at the development of formularies for general practice $(25,1,23,24,12)$. Notwithstanding this positive attitude $(90,155)$ the compliance with guidelines in practice was sometimes disappointing $(16,110)$. Remarkably little importance was attributed to the pharmaceutical industry despite considerable costs spent by them for information on developments and characteristics of new drugs because commercial factors are often suspected $(39,108)$. Doctors said to feel uneasy when being paid for reporting on drug effects to pharmaceutical companies (108). Local pharmacists, however, were readily consulted and their information was valued $(93,95)$. Their professional expertise and 'filtered' information from the industry substantially influenced prescription behaviour $(106,11)$. Regular PTAMs guided by doctors and pharmacists together were also regarded important because many GPs regretted that for lack of time reading professional literature and attending meetings was often hardly possible. They gladly would rely on up to date formularies $(71,97)$.

Concerning the patients (table 2.5). Last but not least, prescription of drugs depends on both subjective and objective patients' influences. One of the latter is the patient's age. In the Netherlands the consumption of drugs by elderly citizens $(>65 \mathrm{y}$.) is 2.9 times the national average (308) and similar patterns are observed in other countries. But also patients' wishes and demands were reported to play a not insignificant role (14). Many patients, when insisting often got what they wanted even in case prescription was not medically justified (14). Concerning tolerability the patient has a major influence on drug selection (88) but information about risks to an individual patient might change the doctor's prescribing (13). The prescribing decision can be greatly influenced by the doctormpatient relationship and patients' satisfaction with the provided treatment is an important feature. In situations where disagreement between the doctor's opinion and the patient's demands existed, the use of a prescription protocol at 
hand on the doctor's desk often proved usefull to come to a decision which was acceptable for both parties $(11,13,10)$.

Conclusion. Reviewing the available literature it can be concluded that many aspects have influence on the prescription of drugs by GPs and the changes in prescribing behaviour. The most important factors appeared to be varying personal qualities of doctors, experienced or known safety/effectiveness balance of drugs, introduction of new drugs, prescription formularies if introduced on a base of common interest and continuing medical education. Remarkably the influence of information supplied by medical representatives was often considered of minor importance notwithstanding the considerable efforts of the pharmaceutical industry. A detailed study on the differences between a group of GPs where no agreements on prescription policy had been made and a group of GPs who aimed at prescription from a limited formulary seemed to be justified and will be reported in the next chapters of this thesis. 


\section{General reference list.}

(cf. page 30 for a reference list in alphabetical order)

1. Anonymous. Medical audit in general practice 1: Effects on doctors' clinical behaviour for common childhood conditions; North of England study of Standards and Performance in General Practice. BMJ 1992; 304: 1480-4

2. Allery $L A$, Owen PA, Robling MR. Why general practitioners and consultants change their clinical practice; a critical incident study, BMJ 1997; 314: 870-4

3. Anderson $G M$, Beers $M H$, Kerluke $K$. Auditing prescription practice using explicit criteria and computerized drug benefit claims data. J Eval Clin Pract 1997; 3(4): 283-94

4. Armstrong $\mathrm{D}$, Reyburn $\mathrm{H}$, Jones $\mathrm{R}$. A study of general practitioners' reasons for changing their prescribing behaviour. BMJ 1996; 312: 949-52

5. Bateman DN, Campbell M, Donaldson LJ, Roberts SJ, Smith JM. A prescribing incentive scheme for non-fundholding general practices: an observational study. BMJ 1996; 313: 535-8

6. Beerworth EE, Tiller JW. Liability in prescribing choice: the example of the antidepressants. Aust N Z J Psychiatry 1998; 32(2): 560-6

7. Berman S, Byrns PJ, Bondy J, Smith PJ, Lezotte D. Otitis media-related antibiotic prescribing patterns, outcomes and expenditures in a pediatric medicaid population. Pediatrics 1997; 100: 585-92

8. Birkett DJ, McManus P. Modelling the market of new drugs following listing for subsidy in Australia. A report from the Drug Utilisation Subcommittee of the Australian Pharmaceutical Benefits Advisory Committee. Br.J.Pharmacol. 1995; 40(4): 407-10

9. Birrer R, Farina G, Rochelle A, Weiner M. Comparative prescription practices of family practice, internal medicine and pediatric residents. Fam. Pract. Res. J. 1990; 9(2): 95-103

10. Bradley CP. Uncomfortable prescribing decisions: a critical incident study BMJ 1992, 304: $294-6$

11. Britten N, Brant $S$, Cairns A, Hall WW, Jones I, Salisbury C, Virji A, Herxheimer A. Continued prescribing of inappropriate drugs in general practice. $\mathbb{J}$ Clin Pharm Ther 1995; 20: 199-215

12. Bryce FP, Neville RG, Crombie IK, Clark RA, McKenzie P. Controlled trial of an audit facilitator in diagnosis and treatment of childhood asthma in general practice. BMJ 1995; 310: 838-42

13. Butler CC, Rolinick $S$, Pill R, Maggs-Rapport F, Stott N. Understanding the culture of prescribing: qualitative study of general practitioners" and patients' perceptions of anitbiotics for sore throats. BMJ 1998; $317: 637-42$ 
14. Cockburn J, Pit S. Prescribing behaviour in clinical practice: patients" expectations and doctors' perceptions of patients expectations- a questionnaire study. BMJ 1997; 315: 520-3

15. Cox $\mathrm{S}$, Wilcock $\mathrm{P}$, Young $\mathrm{J}$. Improving the repeat prescribing proces in a busy general practice. A study using continuous quality improvement methodology. Qual in Health Care 1999; 8: 119-125

16. Damoiseaux RA, de Melker RA, Ausems MJ, van Balen FA. Rreasons for non-guideline-based antibiotic prescriptions for acute otitis media in The Netherlands. Fam Pract 1999; 16: 50-3

17. Denig P, Haaijer-Ruskamp FM. Prescribing decisions of doctors. A review of descriptive decision-making research. Huisarts Wet 1998; 41(6): 274-9

18. Donald JB. On line prescribing by computer. Br Med J Clin Res Ed 1986; 292: $937-9$

19. Dowell JS, Snadden D, Dunbar JA. Changing to generic formulary: how one fundholding practice reduced prescribing costs. BMJ 1995; 310: 505-8

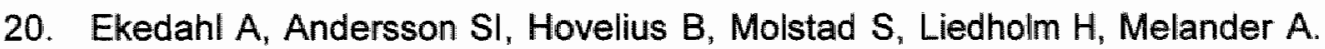
Drug prescription attitudes and behaviour of general practitioners. Effects of a problem-oriented educational programme. Eur J Clin Pharmacol 1995; 47: 381-7

21. Evans JS, Harries C, Dennis I, Dean J. General practitioners' tacit and stated policies in the prescription of lipid lowering agents. $\mathrm{Br} \mathrm{J}$ Gen Pract 1995; 45:15-8

22. Fahey $T$, Sinclair $H$. Hospital initiated prescribing in the general Medical Services scheme. Ir Med J 1993; 86: 122-4

23. Ferguson RI, Maling TJ. The Nelson general practice prescribing project. II Prescribing reports for self audit NZ Med J 1990; 103: $560-2$

24. Ferguson RI, Maling TJ. The Nelson general practice prescribing project. Part I: a pilot audit of the regional prescribing profile. N Z Med J 1990; 103 : $558-60$

25. Fleming DM. Prescribing activity during a period of self audit. Fam Pract $1985 ; 2: 232-4$

26. Fraser RC, Gosling JT. Information systems for general practitioners for quality assessment: 1. Responses of the doctors. Br Med J Clin Res Ed 1985; $291: 1473-6$

27. Glaeske G. Quality control of drug prescriptions by positive lists - - the European Formulary. Int J Clin Pharmacol Ther 1994 32; 403-8

28. Godwin M, Chapman J, Mowat D, Racz W, McBride J, Tang J. Delisting of drugs in Ontario. How attitudes and prescribing strategies of family physicians in the Kingston area changed. Can Fam Physician 1996; 42: 1309-16 
29. Gorter KJ, Ruding PRJW, Luykx MCVM, Van Benthem PP, Delnaij DMJ. Tussen ideaal en werkelijkheid, transmurale zorgafspraken over sinusitis maxillaris door modificatie van de NHG-standaard. Huisarts Wet 1998; 41: 328-32

30. Harding G, Taylor KM. Professional relationships between general practitioners and pharmacists in health centres. Br J Gen Pract 1990; 40: 464-6

31. Haxby DG, Weart CW, Goodman BW. Family practice physicians' perceptions of the usefulness of drug therapy recommendations from clinical pharmacists. Am J Hosp Pharm 1988; 45: 824-7

32. Hill-Smith 1. Sharing resources to create a district drug formulary: a countrywide controlled trial. Br J Gen Pract 1996; 46: 271-75

33. Himmel W, Kron M, Hepe S, Kochen MM. Drug prescribing in hospital as experienced by general practitioners: east versus west Germany. Fam Pract $1996 ; 13: 247-53$

34. Hux JE, Melady MP, DeBoer D. Confidential prescriber feedback and education to improve antibiotic use in primary care: a controlled trial. CMAJ 1999 161: 388-92

35. Knottnerus JA, Dinant GJ. Medicine based evidence, a prerequisite for evidence based medicine. BMJ 1997; 315: 1109-10

36. Koomen JM. Woekeren met je "evoked set en je farmacotherapeutisch redeneervermogen. Pharm Weekbl 1998; 133: 1569 - 74

37. Koomen JM. Hoe kan de geneesmiddelenkeuze worden geoptimaliseerd? Med Cont 1998; 53: 1302 - 5

38. Denig P. Drug choice in medical practice. Thesis Groningen 1994

39. Lexchin J. Pharmaceutical promotion in Canada: convince them or confuse them. Int J Health Serv 1987; 17: 77-89

40. Little $P$, Williamson I, Warner $G$, Gould $C_{\text {n }}$ Gantley M, Kinmonth AL. Open randomised trial of prescribing strategies in managing sore throat. BMJ 1997; 314: 722-7

41. Martin RM, Hilton SR, Kerry SM, Richards NM. General practitioners' perceptions of the tolerability of antidepressant drugs: a comparison of selective serotonin reuptake inhibitors and tricyclic antidepressants. BMJ 1997; 314: 646-51

42. Maxwell M, Howie JG, Pryde CJ. A comparison of three methods of setting prescribing budgets, using data derived from defined daily dose analyses of historic pattern of use. Br J Gen Pract 1998; 48: 1467-72 
43. Mazzaglia G, Arcoraci V, Greco S, Cucinotta G, Cazzola M, Caputi AP. Prescribing habits of general practitioners in choosing an empirical antibiotic regimen for lower respiratory tract infections in adults in Sicily. Pharmacol Res 1999; 40: 47-52

44. Haaijer-Ruskamp FM. Het voorschrijfgedrag van de huisarts (summary in English). Thesis Groningen 1984

45. Mehta SS, Wilcox CS, Schulman KA. Treatment of hypertension in patients with comorbidities: results from the study of hypertensive perscribing practices Am J Hypertens 1999; 12: 333-40

46. Miller E, MacKeigan LD, Rosser W, Marshman J. Effects of perceived patient demand on prescribing anti-infective drugs. CMAJ 1999 161: 139-42

47. Montanaro N, Magrini N, Vaccheri A, Battilana M. Drug utilization in general practice: prescribing habits of National Formulary drugs. Eur $\mathrm{J}$ Clin Pharmacol 1992; 42: $401-8$

48. Morton-Jones T, Pringle M. Explaining variations in prescribing costs across England. BMJ 1993 (306): 1731-4

49. Moser $M$. Why are physicians not prescribing diuretics more frequently in the management of hypertension? JAMA 1998; 279: 1813-6

50. Olesen F, Vedsted P, Norskov-Nielsen J. Change in ranking order of prescribing patterns by age and sex standardization of the practice population--audit may be misleading. Scand J Prim Health Care 1996; 14: 159-64

51. Taroni F, Stiassi $R$, Traversa G, Raschetti $R$, Mennito-Ippolito $F$, Maggini $M$, Spila-Allegiani S. 1990; The nature, content and interpractice variation of general practice: a regional study in Italy. Eur.J.Epidemiol. 6(3): 313-18

52. Penrose $A$, Dodey $S$, Tilyard $M$. Trends in antihypertensive prescribing. $\mathbf{N} Z$ Med J 1996, 109: 4-7

53. Petursson $P$. What determines a family doctor's prescribing habits for antibiotics? A comparative study on a doctor's own behaviour in two different settings. Scand J Prim Health Care 1996; 14: 196-202

54. Rosholm JU, Gram LF, Isacsson G, Hallas J, Bergman U. Changes in patterns of antidepressant use upon the introduction of the new antidepressants: a prescription database study. Eur J Clin Pharmacol 1997; 52. 205-9

55. Rothberg $A D$, Walters $L$. Formulary and funding implications of the gap between the national Essential Drugs List and current prescribing in a large health maintenance organisation. S Afr Med J 1996; 86:1084 - 90

56. Roughead EE, Gilbert AL, Primrose JG. Improving drug use: a case study of events which led to changes in use of flucloxacillin in Australia. Soc Sci Med 1999 48: $845-53$ 
57. Sclar DA, Robinson $L M_{*}$ Skaer $T L$, Galin RS. What factors influence the prescribing of antidepressant pharmacotherapy? An assessment of national office-based encounters. Int J Psychiatry Med 1998; 28: 407-19

58. Steven ID, Wilson DH, Wakefield MA, Beilby J, Coffey GA, Esterman AJ, Golding AP, Graham NM, Litt JC, Rohrsheim RA. 1992; South Australian hypertension survey. General practitioner experiences with drug treatment. Med. J. Australia 156(9): $641-4$

59. Seneviratne SL, Gunatilake SB, Adhikari AA, Gunawardhana P, de Silva HJ. Changing prescribing behaviour: early low dose aspirin in suspected acute myocardial infarction. Int J Cardiol 1998; $67: 237-40$

60. Shasha $\mathrm{M}_{3}$, Lyons JS, O'Mahoney MT, Rosenberg, Miller SI, Howard KI. Serotonin reuptake inhibitors and the adequacy of antidepressant treatment. Int J Psychiatry Med 1997; 27: 83-92

61. Tomson $Y$, Wessling A, Tomson $G$. General practitioners for rational use of drugs. Examples from Sweden.

Eur J Clin Pharmacol 1994; 47: 213-9

62. Rosmalen CFH, Thomas S. Farmacotherapie voor de huisarts; zakboekje. Ned. Huisartsen Genootschap, Utrecht 1996

63. Vries de CS, van Diepen $\mathrm{NM}$ Tromp TF, de Jong van den berg LT. Auditing GP's prescribing habits: cardiovascular prescribing frequently continues medication initiated by specialists.

Eur J Clin Pharmacol 1996; 50: 349-52

64. Kamps GB. Formularies and their use by general practitioners. Thesis Groningen 1999 (in Dutch; summary in English).

65. Vries de TP, Henning RH, Hogerzeil HV, Bapna JS, Bero L, Kafle KK, Mabadeje Af, Santoso B, Smith AJ. Impact of short course in pharmacology for undergraduate medical students; an international randomised controlled study. Lancet 1995, 346: 1454-7

66. Walzak D, Swindells 5, Bhardwaj A. Primary care physicians and the cost of drugs: a study of prescribing practices based on recognition and information sources. J Clin Pharmacol 1994; 34: 1159 - 63

67. Weiss MC, Fitspatrick R, Scott DK, Goldacre MJ. Pressures on the general practitioner and decisions to prescribe. Fam Pract 1996; 13:432-8

68. Wierenga $B$, Jong SJ, Mantel AF. The decision making process of family physician in choosing a drug. NTvG 1989 133 115-22

69. Wilson RP, Hatcher J, Barton S, Walley $\mathrm{T}$. Influences of practice characteristics on prescribing in fundholding and non-fundhoiding general practices; an observational study. BMJ 1996; 313: 595-9 
70. Wyatt TD, Passmore CM, Morrow NC, Reilly PM. Antibiotic prescribing: the need for a policy in general practice. BMJ 1990; 300: 441-4

71. Wyatt TD, Reilly PM, Morrow NC, Passmore CM. Short-lived effects of a formulary on anti-infective prescribing - the need for continuing peer review? Fam Pract 1992; 9: 461-5

72. Schwartz JA, Chapman GB. Are more options always better? The attraction effect in physicians' decisions about medications. Med Decis Making 1999; 19(3): $315-23$

73. Gill PS, Makela M, Vermeulen KM, Freemantle $N$, Ryan G, Bond C, Thorsen T. Haayer-Ruskamp FM. 1999; Changing doctor prescribing behaviour. Pharm. World Sci. 21(4): 158-167

74. Van der Ree CM, Mokkink HGA, Van den Hoogen HJM, Grol R. 1998; A therapy decision support system (ETAS) for general practitioners. A pilot study. Huisarts Wet 41/9: 413-5

75. Van der Ree CM, Gubbels JW, Goemans LAC, Been P.1999; Een electronisch voorschrijfsysteem. Med.Contact 54(31/32): 1096-9

76. Advies Stuurgroep kwaliteit en doelmatigheid therapeutische zorg lange termijn. Ministerie van WWS; mei 1998 (Ministry of Public Health)

77. Dowell JS, Snadden D, Dunbar JA. Rapid prescribing change, how do patients respond? Soc Sci Med 1996 43: 1543-9

78. Buetow SA, Sibbald B, Cantrill JA, Halliwell S. Prevalence of potentially inappropriate long term prescribing in general practice in the United Kingdom 1980 - 95: systemic literature review. BMJ 1996 (313): 1371-4

79. Hodges B. Interactions with the pharmaceutical industry: experiences and attitudes of psychiatry residents, interns and clerks. CMAJ 1995 153: 553-9

80. Blake RL, Early EK. Patients' attitude about gifts to physicians from pharmaceutical companies. J Am Board Fam Pract 1995 8: 457-64

81. Blom AT, Paes AH, Bakker A, Koopman CJ, Meer van der C. Pharmacist-physician co-operation at a regional level.

Pharm World Sci 1994 16: 13-7

82. Dixon T. Pharmaceutical advertising. Information or influence? Can Fam Physician 1993; 39: 1302-4

83. Gibbons RV, Landry FL, Blouch DL, Jones DL, Williams FK, Lucey CR, Kroenke K. A comparison of physicians' and patients' attitudes toward pharmaceutical industry gifts. J Gen Intern Med 1998 13: 151-4

84. Peppin JF. An Engelhardtian analysis of interaction between pharmaceutical sales representatives and physicians. J Med Philos 1997 22: 623-41 
85. Madhavan $S$, Amonkar MM, Eliott D, Burke K, Gore P. The gift relationship between pharmaceutical companies and physicians: an exploratory survey of physicians. J Clin Pharm Ther 1997; 22: 207-15

86. Caudill TS, Johnson MS, Rich EC, McKinney WP Physicians, pharmaceutical sales representatives, and the cost of prescribing. Arch Fam Med $1996 ; 5: 201-6$

87. Peppin JF. Pharmaceutical sales representatives and physicians: ethical considerations of a relationship. J Med Philos 1996 21: 83-99

88. Vries de $\mathrm{CS}_{4}$ Duggan CA, Tromp TF, de Jong van den Berg LT C hanging prescribing in the light of tolerability concerns: how is this best achieved? Drug Saf 1999; 21: 153-60

89. Vries de CS, Berg van den PB, Timmer JW, Reicher A, Blijleven W, Tromp ThFJ, Jong de-van de Berg LTW.1999; Prescription data as a tool in pharmacology audit (II): the development of an instrument. Pharm. World Sci. 21(2): $85-90$

90. Overdyk FJ, Harvey SC, Baldwin D, Rust P, Multani M, Marcell J. Individualized outcome feedback produces voluntary antiemetic prescribing practice changes J Clin Anesth 1999; 11: 17-23

91. Avery AJ, Heron T, Lloyd $D$, Harris CM, Roberts $D$. Investigating relationships between a range of potential indicators of general practice prescribing: an observational study. J Clin Pharm Ther 1998; 23:441-50

92. Oxman AD, Thomson MA, Davis DA, Haynes RB. No magic bullets: a systematic review of 102 trials of interventions to improve professional practice. CMAJ 1995 153: 1423-31

93. Diwan VK, Wahlstrom R, Tomson $G$, Beermann B, Sterky G, Eriksson B. Effects of "group detailing" on the prescribing of lipid-lowering drugs: a randomized controlled trial in Swedish primary care. J Clin Epidemiol 1995; 48: $705-11$

94. Maclure M, Dormuth C, Naumann T, McCormack J, Ragno R, Whiteside C, Wright JM. Influences of educational interventions and adverse news about calcium-channel blockers on first-line prescribing of antihypertensive drugs to elderly people in British Columbia. Lancet 1998; 352: 943-8

95. Hanlon JT, Weinberger M, Samsa GP, Schmader KE, Uttech KM, Lewis IK, Cowper PA, Landsman PB, Cohen HJ, Feussner JR. A randomized, controlled trial of clinical pharmacist intervention to improve inappropriate prescribing in elderly outpatients with polypharmacy.

Am J Med. 1996; 100: 428-37 
96. Miller $F$, Jacques $A$, Brailovsky $C$, Sindon $A$, Bordage $G$. When to recommend compulsory versus optional CME programs? A study to establish criteria. Acad Med; 1997 (72): 760-4

97. Kochen MM, Sandholzer $\mathrm{H}$, Himmel $\mathrm{W}$. Attitudes of primary care physicians towards the use of a drug formulary- preliminary results of a study in Germany. Int J Clin Pharmacol Ther 1994 32; 400-2

98. Griffin JP, Griffin TD. The economic omplications of therapeutic conservatism. J R Coll Physicians Lond; 1993 27: 121-6

99. Martin BC, McMillan JA. The impact of implementing a more restrictive prescription limit on Medicaid recipients. Effects on cost, therapy and out-of-pocket expenditures. Med Care 1996; 34, 686-701

100. Steffensen FH, Soresen HT, Olesen F. Diffusion of new drugs in Danish general practice. Fam Pract 1999; 16:407-13

101. Robinson A. After years of steady growth, winds of restraint blowing on prescription-drug industry. CMAJ 1995; 153: 85-8

102. McGavock $H$, Webb $C H$, Johnston $G$, Milligan $E$. Market penetration of new drugs in one United kingdom region: implications for general practitioners and administrators. BMJ 1993 (307): 1118-20

103. Inman W, Pearce $G$. Prescriber profile and post marketing surveillance. Lancet 1993; 342: 658-61

104. Anderson GM, Kerluke KJ, Pulcins IR, Hertzman C, Barer ML. Trends and determinats of prescription drug expentidures in the elderly: data from the British Columbia Pharmacare Program. Inquiry 1993; 30: 199-207

105. Cosentino $M$, Leoni $O$, Banfi $F$, Lecchini $S$, Frigo $G$. Attitudes to adverse drug reaction reporting by medical practitioners in a Northern Italian district. Pharmacol Res 1997; 35: 85-8

106. Vries de CS, Tromp TF, Blijleven W, de Jong van den Berg LT. Prescription data as a tool in pharmacotherapy audit (1). General considerations. Pharm World Sci 1999; $21: 80-4$

107. Yeo GT, de Burgh SP, Letton T, Shaw J, Donnelly N, Swinburn ME, Phillips $S$, Bridges-Webb $C$, Mant A. Educational visiting and hypnosedative prescribing in general practice. Fam Pract 1994; 11: 57-61

108. Lexchin J. Interactions between physicians and the pharmaceutical industry: what does the literature say? CMAJ 1993; 149: 1401-7

109. Sylvester SH. General practitioners' attitudes to professional reaccreditation. BMJ 1993; 307: 912-4

110. Kljakovic M, McLeod D. Management of acute asthma: gaps between opinion and recorded action by general practitioners.

Qual in Health Care 1997; 9: 405-12 
111. Pickering TD, Gurwitz JH, Zaleznik D, Noonan JP, Avorn J. The appropriateness of oral fluoroquinolone-prescribing in the long-term care setting. J Am Geriatr Soc 1994; 42: 28-32

112. Alderman $\mathrm{MH}$, Madhavan S, Cohen $\mathrm{H}$. Antihypertensive Drug Therapy. The effect of Joint National Committee criteria on prescribing patterns and patient status through the first year. Am J Hypertens 1996; 9: 413-8

113. Schubert I, Ihle P, Koster I, Ferber von L.1999; Markers to analyse the prescribing of non-steroidal anti-inflammatory drugs in ambulatory care. Eur. J.Clin.Pharmacol. 55: 479-86

114. Avery AJ, Walker $B$, Heron T, Teasdale SJ. Do prescribing formularies help GPs prescribe from a narrower range of drugs? A controlled trial of the introduction of prescribing formularies for NSAlDs. Br J Gen Pract 1997; 47: $810-4$

115. Spearman ME, Summers $K$, Moore $V$, Jacqmin R, Smith $G$, Groshen $S$. Cost-effectiveness of initial therapy with 3-hydroxy-3-methylglutaryl coenzyme $A$ reductase inhibitors to treat hypercholesterolemia in a primary care setting of a managed-care organization. Clin Ther 1997; 19:538-9

116. Ferner RE. 1996; Newly licensed drugs. BMJ 313: 1157-8

117. Kiezen en delen: rapport van de Commissie 'Keuzen in de Zorg' (commissie Dunning). Rijswijk: Ministerie van Welzijn, Volksgezondheid en Cultuur, 1991

118. Grant GB, Gregory AD, Zwanenberg TA van. Development of a limited formulary for general practice. Lancet 1985 ; I: 1030-2

119. Essex B. Practice formularies: Towards more rational prescribing. BMJ 1989; 298: 1052.

120. Green PE. The general practice formulary; its role in rational therapeutics. J R Coll Gen Pract 1985: 35: 570-2.

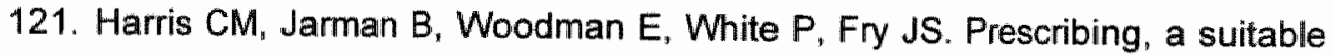
case for treatment. London, Royal College of General Practitioners, 1984. (Occasional paper 24)

122. Everdingen JJE van, Van consensus naar CBO-richtlijn. Ned Tijdschr Geneesk 1999; 143: 2086-2089

123. Kamps GB, Meyboom-de Jong B. Regionale formularia voor huisartsen vergeleken. Ned Tijdschr Geneesk 1997; 141: 1002-7

124. Kirwan JR, Chaput de Saintonge DM, Joyce CRB. Clinical judgement analysis. Quart J Med 1990; 76: 935 - 49

125. Luijn van JCF, Loenhout van JWA, Riteco JA, Ripken T. Toetsing van het geneesmiddelenpakket.

Med Cont 1995; (50): 1433-38 
126. Rosmalen $\mathrm{CFH}$, Thomas $\mathrm{S}$. Farmacotherapie voor de huisarts. Achtergronden. Ned. Huisartsen Genootschap. Utrecht 1996.

127. Schuling J, Toenders WGM. Evidence based medicine: betekenis voor de farmacotherapie.

Geneesm Bull 1999; 33: 71 - 7

128. Farmacotherapeutisch Kompas, Centrale Medisch Pharmaceutische Commissie van de Ziekenfondsraad, Roto Smeets Utrecht, Utrecht, 1999

129. Kerremans ALM. De vervanging van klassieke geneesmiddelen door nieuwe. Geneesm Bull 1996; 30, 63 - 9

130. Van der Weijden T, Grol RPTM, Knottnerus JA. Feasibility of a national cholesterol guideline in daily practice. A randomized controlled trial in 20 general practices. Int.J.Qual. Health Care 1999; 11: 131-7

131. Saturno PJ, Palmer RH, Gascon JJ. Physician attitudes, self estimated performance and actual compliance with locally peer-defined quality evaluation criteria. Int $J$ Qual Health Care 1999; 11: $487-49$

132. Stichting Farmaceutische Kengetallen (Foundation for Pharmaceutical Statistics; English text). The Hague / The Netherlands; September 1999

133. Chapman S. Drug formularies good or evil? A view using prescribing analyses and cost trends data. Cardiology 1994; 85 suppl1: 46-53

134. Glazer WM. Formulary decisions and health economics. J Clin Psychiatry 1998; 59 suppl. 19: 23-9

135. Liset van Dijk, Landelijke inventarisatie FTO; regio Zuidoost Brabant en regio Limburg. Stichting NIVEL, Utrecht 1999

136. Johnson JA, Bootman JL. Pharmacoeconomic analysis in formulary decisions: an international perspective. Am J Hosp Pharm 1994; 51: 2593-8

137. Statistisch Jaaroverzicht 1996, IMS, Den Haag

138. Dekker W. Marktwerking in de gezondheidszorg, Ministerie van Welzijn, Volksgezondheid en Cultuur, Rijswijk 1987.

139. Rapport van de IWG, Ministerie van Volksgezondheid, Welzijn en Sport, Rijswijk 1994.

140. Rapport van de MDW-werkgroep, Ministerie van Volksgezondheid "Welzijn en Sport, Rijswijk, 1999

141. Rapport van de BCG B.V. aan Zorgverzekeraars Nederland (BCG-Report), Zeist, 1999

142. Langley PC. The role of pharmacoeconomic guidelines for formulary approval; the Australian experience. Clin Ther 1993; 15: 1154-76 and 1120

143. Bergman U, Vaccheri A, Goransson P. Wettermark B, Montanaro $\mathbb{N}$. Prescribing NSAIDs in relation to the drug market: an Italian-Swedish comparison. Eur J Clin Pharmacol 1997; 52[suppl]: A37:34 
144. Anderson M, Bjerrum L, Wettermark B, Arrhenius L, Gram LF, Bergman U. Prescribing patterns of NSAIDs in Denmark and Sweden using the DU90\% methodology. Eur J Clin Pharmacol 1997; 52[suppl]: A37:31

145. Popa $C$, Tomson $Y$, Enfeldt $P$, Bergman U. Prescribing profiles as indicators for rational use of drugs. Eur $\mathrm{J}$ Clin Pharmacol 1997; 52[suppl]: A46-69

146. O'Connell D, Henry D, Tomlins R. Randomised controlled trial of effect of feed back on general practitioners' prescribing in Australia. BMJ 1999; 318: 507-11

147. Anonymus. NHG-standaarden. Richtlijnen voor het handelen en de praktijkvoering van de huisarts, I en II. Nederlands Huisartsen Genootschap; Utrecht.

149. Burgers JS, Wiersma Tj, Meulenberg F. De status van de NHG-standaarden: balanceren tussen wetenschap en verhaal. Huisarts Wetensch 1998; 41: $381-4$

150. Van Wijmen FCB, Lagro-Janssen ALM. Richtlijn, plichtlijn? Professionele autonomie volgens de WGBO. Huisarts Wetensch 1998; 41: 607-9, 616

151. Anonymous. Waardebepaling geneesmiddelen als beleidsinstrument. Raad voor de Volksgezondheid en Zorg, Zoetermeer 1997.

152. Beardon PHG, Brown SV, Mowat DAE, Grant JA, McDevitt DG. Introducing a drug formulary to general practice, effects on practice prescribing costs. J R Coll Gen Pract 1987; 37 : 305-307

153. Wyatt J, Walton R. Computer based prescribing. BMJ 1995; $311: 1181-2$

154. Himmel W, Lonker B, Kochen MM. Nonformulary drug requests at an academic hospital in Germany- the role of general practitioners' long-term medication. Eur Clin Pharmacol 1998; 54: 41-46

155. Hoogen v.d.JJM, Hooijman GLJ, Meulepas M. Bottom-up approach of local pharmacotherapeutic consultations involving pharmacists and general practitioners. Pharm Weekbl 1999; 134: 1400-1404

156. Sacket DL, Rosenberg WMC, Gray JAM Haynes RB, Richardson WS. Evidence based medicine: what it is and what it isn't.

BMJ 1996; 312: 71-2

157. Brenninkmeijer RF, Janknegt $R$. Het gebruik van matrixmethoden in de farmacotherapie. Geneesm Bulletin 2000; 34: 41-46

160. Rolle C, Ferraro L, Marrazzo E, Ostino $G$. Change in prescribing patterns of general practitioners in Italy before and after the Reform Drug Act. A case study in the city of Turin. Pharm World Sci 1995; 17: 158-62

161. Rafferty $T$, Wilson-Davis $K$, McGavock $H$. How has fundholding in Horthern Ireland affected prescribing patterns? A longitudinal study. BMJ 1997; 315: 166-70 
162. Anonymous. Farmaceutische zorg door arts en apotheker. Raad voor de Volksgezondheid en Zorg. Zoetermeer 1998.

179. Davidson W, Molloy DW, Somers G, Bedard M. Relation between physician characteristics and prescribing for elderly people in New Brunswick. CMAJ 1994; 150: $917-21$

181. Lexchin J. Improving the appropriateness of physicians prescribing. Int $\mathrm{J}$ Health Serv 1998; 28: 253-67

183. Vries de TPGM. Presenting clinical pharmacology and therapeutics: general introduction. Br J Clin Pharmac 1993; 35: 577-9

210. Bergman $U$, Popa $C$, Tomson $Y$, Wettermark B, Einarson TR, Aberg $H$, Sjöqvist $F$. Drug utilization $90 \%$ - a simple method for assessing the quality of drug prescribing. Eur.J.Clin.Pharmacol.1998; 54: 113-8 
- Advies Stuurgroep kwaliteit en doelmatigheid therapeutische zorg lange termijn. Ministerie van VWS; mei 1998 (Ministry of Public Health) . . . . . . 76 - Alderman MH, Madhavan S, Cohen H. Antihypertensive Drug Therapy. The effect of Joint National Committee criteria on prescribing patterns and patient status through the first year. Am J Hypertens 1996; 9: 413-8 - Allery LA, Owen PA, Robling MR. Why general practitioners and consultants change their clinical practice; a critical incident study, BMJ 1997; 314:870-4 . 2 - Anderson M, Bjerrum L, Wettermark B, Arrhenius L, Gram LF, Bergman U. Prescribing patterns of NSAIDs in Denmark and Sweden using the DU90\% methodology. Eur J Clin Pharmacol 1997; 52[suppl]: A37:31 . . . . . . . 144 - Anderson GM, Kerluke KJ, Pulcins IR, Hertzman C, Barer ML. Trends and determinants of prescription drug expenditures in the elderly: data from the British Columbia Pharmacare Program. Inquiry 1993; 30: 199-207 . . . . . 104 - Anderson GM, Beers MH, Kerluke K. Auditing prescription practice using explicit criteria and computerized drug benefit claims data.

J Eval Clin Pract 1997; 3(4): 283-94 . . . . . . . . . . . . . . . . . . 3 - Anonymous. Medical audit in general practice I: Effects on doctors' clinical behaviour for common childhood conditions; North of England study of Standards and Performance in General Practice. BMJ 1992; 304: 1480-4 . . . . 1 - Anonymus. NHG standaarden. Richtlijnen voor het handelen en de praktijkvoering van de huisarts, I en II.

Nederlands Huisartsen Genootschap; Utrecht. . . . . . . . . . . . . . . . 147

- Anonymous. Waardebepaling geneesmiddelen als beleidsinstrument. Raad voor de Volksgezondheid en Zorg. Zoetermeer 1997

- Anonymous. Farmaceutische zorg door arts en apotheker. Raad voor de Volksgezondheid en Zorg. Zoetermeer 1998

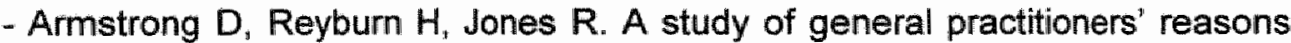
for changing their prescribing behaviour. BMJ 1996; 312: 949-52 . . . . . 4 - Avery AJ, Walker B, Heron T, Teasdale SJ. Do prescribing formularies help GPs prescribe from a narrower range of drugs? A controlled trial of the introduction of prescribing formularies for NSAIDs.

Br J Gen Pract 1997; 47: 810-4 ... . . . . . . . . . . . . . . . . . . . 114 - Avery AJ, Heron T, Lloyd D, Harris CM, Roberts D. Investigating relationships between a range of potential indicators of general practice prescribing: an observational study. J Clin Pharm Ther 1998; $23: 441-50 \ldots . . . \ldots . .91$ 
- Bateman DN, Campbell M, Donaldson LJ, Roberts SJ, Smith JM. A prescribing incentive scheme for non-fundholding general practices: an oberservetional study. BMJ 1996; 313: 535-8 5

- Beardon PHG, Brown SV, Mowat DAE, Grant JA, McDevitt DG. Introducing a drug formulary to general practice, effects on practice prescribing costs. J R Coll Gen Pract 1987; 37 : 305-307 152

- Beenworth EE, Tiller JW. Liability in prescribing choice: the example of the antidepressants. Aust N Z J Psychiatry 1998; 32(2): 560-6 . . . . . . . . . 6

- Bergman U, Popa C, Tomson Y, Wettermark B, Einarson TR, Aberg H, Sjöqvist $F$. Drug utilization $90 \%$ - a simple method for assessing the quality of drug prescribing. Eur.J.Clin.Pharmacol.1998; 54: 113-8 210 - Bergman U, Vaccheri A, Goransson P, Wettermark B, Montanaro N. Prescribing NSAIDs in relation to the drug market: an Italian-Swedish comparison. Eur J Clin Pharmacol 1997; 52[suppl]: A37:34 . . . . . . . . . . . . 143

- Berman S, Byrns PJ, Bondy J, Smith PJ, Lezotte D. Otitis media-related antibiotic prescribing patterns, outcomes and expenditures in a pediatric medicaid population. Pediatrics $1997 ; 100: 585-92 \ldots \ldots \ldots \ldots \ldots \ldots 7$

- Birkett DJ, McManus P. Modelling the market of new drugs following listing for subsidy in Australia. A report from the Drug Utilisation Subcommittee of the Australian Pharmaceutical Benefits Advisory Committee.

Br.J.Pharmacol. 1995; 40(4): 407-10

- Birrer R, Farina G, Rochelle A, Weiner M. Comparative prescription practices of family practice, internal medicine and pediatric residents. Fam.Pract. Res. J. 1990; 9(2): 95-103

- Blake RL, Early EK. Patients' attitude about gifts to physicians from pharmaceutical companies. J Am Board Fam Pract 1995 8: 457-64 . . . . . . . . 80 - Blom AT, Paes AH, Bakker A, Koopman CJ, Meer van der C. Pharmacist-physician co-operation at a regional level. Pharm World Sci 1994

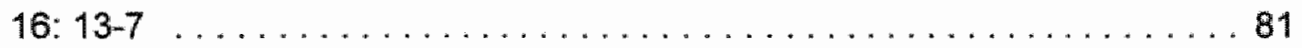

- Bradley CP. Uncomfortable prescribing decisions: a critical incident study;

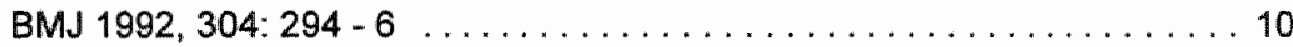

- Brenninkmeijer RF, Janknegt R. Het gebruik van matrixmethoden in de farmacotherapie. Geneesm Bulletin 2000; 34: 41-46 . . . . . . . . . . 157 - Britten N, Brant S, Cairns A, Hall WW, Jones I, Salisbury C, Virji A, Herxheimer A. Continued prescribing of inappropriate drugs in general practice. $\mathrm{J}$ Clin Pharm Ther 1995; 20: 199-215 
- Bryce FP, Neville RG, Crombie IK, Clark RA, McKenzie P. Controlled trial of an audit facilitator in diagnosis and treatment of childhood asthma in general

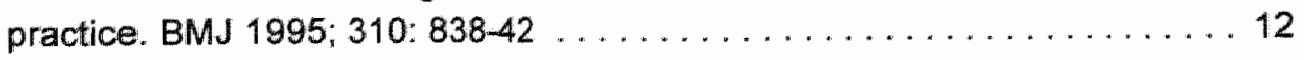
- Buetow SA, Sibbald B, Cantrill JA, Halliwell S. Prevalence of potentially inappropriate long term prescribing in general practice in the United Kingdom 1980 95: systemic literature review. BMJ 1996 (313): $1371-4 \ldots \ldots \ldots \ldots \ldots .78$ - Butler CC, Rollnick S, Pill R, Maggs-Rapport F. Stott N. Understanding the culture of prescribing: qualitative study of general practitioners" and patients" perceptions of anitbiotics for sore throats. BMJ 1998; $317: 637-42 \ldots \ldots .13$ - Caudill TS, Johnson MS, Rich EC, McKinney WP Physicians, pharmaceutical sales representatives, and the cost of prescribing. Arch Fam Med 1996; 5: 201-6 86

- Chapman S. Drug formularies good or evil? A view using prescribing analyses and cost trends data. Cardiology 1994; 85 suppl1: $46-53 \ldots \ldots \ldots \ldots 133$ - Cockburn J, Pit S. Prescribing behaviour in clinical practice: patients' expectations and doctors' perceptions of patients expectations- a questionnaire study. BMJ 1997; 315: 520-3 14

- Cosentino M, Leoni O, Banfi F, Lecchini S, Frigo G. Attitudes to adverse drug reaction reporting by medical practitioners in a Northern Italian district.

Pharmacol Res 1997; 35: 85-8 . . . . . . . . . . . . . . . . . . 105 - Cox S, Wilcock P, Young J. Improving the repeat prescribing proces in a busy general practice. A study using continuous quality improvement methodology.

Qual in Health Care $1999 ; 8: 119-125 \ldots \ldots \ldots \ldots \ldots \ldots$

- Damoiseaux RA, de Melker RA, Ausems MJ, van Balen FA. Rreasons for non-guideline-based antibiotic prescriptions for acute otits media in The Netherlands. Fam Pract $1999 ; 16: 50-3 \ldots \ldots \ldots \ldots \ldots \ldots \ldots$

- Davidson W, Molloy DW, Somers G, Bedard M. Relation between physician characteristics and prescribing for elderly people in New Brunswick.

CMAJ 1994; 150: 917-21

- Dekker W. Marktwerking in de gezondheidszorg, (Rapport van de commissie Dekker) Ministerie van Welzijn, Volksgezondheid en Cultuur, Rijswijk, 1987. 138 - Denig P. Haaijer-Ruskamp FM. Prescribing decisions of doctors. A review of descriptive decision-making research. Huisarts Wet 1998; 41(6): 274-9 . . 17 - Denig P. Drug choice in medical practice. Thesis Groningen 1994 . . . . . 38 - Dijk, Liset van. Landelijke inventarisatie FTO; regio Zuidoost Brabant en regio Limburg. Stichting NIVEL, Utrecht 1999 135 
- Diwan VK, Wahlstrom R, Tomson G, Beermann B, Sterky G, Eriksson B. Effects of "group detailing" on the prescribing of lipid-lowering drugs: a randomized controlled trial in Swedish primary care. J Clin Epidemiol 1995; 48: 705-193 - Dixon T. Pharmaceutical advertising. Information or influence? Can Fam Physician 1993; 39: 1302-4

- Donald JB. On line prescribing by computer.

Br Med J Clin Res Ed 1986; 292: 937-9.

- Dowell JS, Snadden D, Dunbar JA. Changing to generic formulary: how one fundholding practice reduced prescribing costs. BMJ 1995; 310: 505-8 . . . 19 - Dowell JS, Snadden D, Dunbar JA. Rapid prescribing change, how do patients respond? Soc Sci Med 1996 43: 1543-9

- Ekedahl A, Andersson SI, Hovelius B, Molstad S, Liedholm H, Melander A. Drug prescription attitudes and behaviour of general practitioners. Effects of a problem-oriented educational programme.

Eur J Clin Pharmacol 1995; 47: 381-7

- Essex B. Practice formularies: Towards more rational prescribing.

BMJ 1989; 298: 1052.

- Evans JS, Harries C, Dennis I, Dean J. General practitioners' tacit and stated policies in the prescription of lipid lowering agents.

Br J Gen Pract 1995; 45:15-8

- Everdingen JJE van, Van consensus naar CBO-richtlijn. Ned Tijdschr Geneesk 1999; 143: 2086-2089

- Fahey T, Sinclair H. Hospital initiated prescribing in the gerenal Medical Services scheme. Ir Med J 1993; 86: 122-4 .

22

- Farmacotherapeutisch Kompas, Centrale Medisch Pharmaceutische Commissie van de Ziekenfondsraad, Roto Smeets Utrecht "Utrecht, 1999

- Ferguson RI, Maling TJ. The Nelson general practice prescribing project.

Part 1: a pilot audit of the regional prescribing profile.

N Z Med J 1990; 103: $558-60$.

- Ferguson RI, Maling TJ. The Nelson general practice prescribing project. II Prescribing reports for self audit $\mathrm{N} Z$ Med $\mathrm{J} 1990 ; 103: 560-2 \ldots \ldots .23$

- Ferner RE. 1996; Newly licensed drugs. BMJ 313: 1157-8 . . . . . . . . 116

- Fleming DM. Prescribing activity during a period of self audit. Fam Pract 1985;

2: $232-4$

- Fraser RC, Gosling JT. Information systems for general practitioners for quality assessment: 1. Responses of the doctors.

Br Med J Clin Res Ed 1985; 291: 1473-6 
- Gibbons RV, Landry FL, Blouch DL, Jones DL, Williams FK, Lucey CR, Kroenke K. A comparison of physicians' and patients' attitudes toward pharmaceutical industry gifts. J Gen Intern Med $199813: 151-4 \ldots . . . \ldots . . .83$ - Gill PS, Makela M, Vermeulen KM, Freemantle N, Ryan G, Bond C, Thorsen

- T, Haayer-Ruskamp FM. 1999; Changing doctor prescribing behaviour. Pharm. World Sci. 21(4): 158-167

- Glaeske G. Quality control of drug prescriptions by positive lists - - the European Formulary. Int J Clin Pharmacol Ther 1994 32; 403-8 . . . . . . . . . 27 - Glazer WM. Formulary decisions and health economics. J Clin Psychiatry 1998; 59 suppl. 19: 23-9 . . . . . . . . . . . . . . . . . . . 134 - Godwin M, Chapman J, Mowat D, Racz W, McBride J, Tang J. Delisting of drugs in Ontario. How attitudes and prescribing strategies of family physicians in the Kingston area changed. Can Fam physician 1996; $42: 1309-16$. . . 28 - Gorter KJ, Ruding PRJW, Luykx MCVM, Van Benthem PP, Delnoij DMJ. Tussen ideaal en werkelijkheid, transmurale zorgafspraken over sinusitis maxillaris door modificatie van de NHG-standaard. Huisarts Wet 1998; 41: 328-32 29

- Grant GB, Gregory AD, Zwanenberg TA van. Development of a limited formulary for general practice. Lancet 1985; I: 1030-2 . . . . . . . . . . 118 - Green PE. The general practice formulary; its role in rational therapeutics.

J R Coll Gen Pract 1985: 35: 570-2. . . . . . . . . . . . . . . . . . . . 120

- Griffin JP, Griffin TD. The economic complications of therapeutic conservatism. J R Coll Physicians Lond; $199327: 121-6 \ldots \ldots \ldots \ldots . . . . . .98$ - Haaijer-Ruskamp FM. Het voorschrijfgedrag van de huisarts (summary in English). Thesis Groningen 1984

- Hanlon JT, Weinberger M, Samsa GP, Schmader KE, Uttech KM, Lewis IK, Cowper PA, Landsman PB, Cohen HJ, Feussner JR. A randomized, controlled trial of clinical pharmacist intervention to improve inappropriate prescribing in elderly outpatients with polypharmacy.Am J Med. 1996; 100: 428-37 . . . . . 95 - Harding G, Taylor KM. Professional relationships between general practitioners and pharmacists in health centres. Br J Gen Pract 1990; 40: 464-6 30 - Harris CM, Jarman B, Woodman E, White P. Fry JS. Prescribing, a suitable case for treatment. London, Royal College of General Practitioners, 1984. (Occasional paper 24)

- Haxby DG, Weart CW, Goodman BW. Family practice physicians' perceptions of the usefullness of drugtherapy recommentations from clinical pharmacists. Am J Hosp Pharm 1988; 45: 824-7 
- Hill-Smith I. Sharing resources to create a district drug formulary: a countwide controlled trial. Br J Gen Pract 1996; 46: 271-75 . . . . . . . . . . 32 - Himmel W, Kron M, Hepe S, Kochen MM. Drug prescribing in hospital as experienced by general practitioners: east versus west Germany. Fam Pract $1996 ; 13: 247-53$

- Himmel W, Lonker B, Kochen MM. Nonformulary drug requests at an academic hospital in Germany- the role of general practitioners' long-term medication. Eur Clin Pharmacol 1998; 54: 41-46.

- Hodges B. Interactions with the pharmaceutical industry: experiences and attitudes of psychiatry residents, interns and clerks.

CMAJ 1995 153: 553-9.

- Hoogen v.d.JJM, Hooijman GLJ, Meulepas M. Bottom-up approach of local pharmacotherapeutic consultations involving pharmacists and general practitioners. Pharm Weekbl 1999; 134: 1400-1404

155

- Hux JE, Melady MP, DeBoer D. Confidential prescriber feedback and education to improve antibiotic use in primary care: a controlled trial. CMAJ 1999 161: 388-92

- Inman W, Pearce G. Prescriber profile and post marketing surveillance. Lancet 1993; 342: 658-61

- Johnson JA, Bootman JL. Pharmacoeconomic analysis in formulary decisions: an international perspective. Am J Hosp Pharm 1994; 51: 2593-8

- Kamps GB, Meyboom-de Jong B. Regionale formularia voor huisartsen vergeleken. Ned Tijdschr Geneesk 1997; 141: 1002-7

- Kamps GB. Formularies and their use by general practitioners. Thesis Groningen 1999 (in Dutch; summary in English).

- Kerremans ALM. De vervanging van klassieke geneesmiddelen door nieuwe. Geneesm Bull 1996; 30, 63 - 9

- Kirwan JR, Chaput de Saintonge DM, Joyce CRB. Clinical judgement analysis. Quart J Med 1990; 76: 935 - 49

- Kljakovic M, McLeod D. Management of acute asthma: gaps between opinion and recorded action by general practitioners.

Qual in Health Care 1997; 9: 405-12

- Knottnerus JA, Dinant GJ. Medicine based evidence, a prerequisite for evidence based medicine. BMJ 1997; 315: 1109-10 . . . . . . . . . . . 35 - Kochen MM, Sandholzer H, Himmel W. Attitudes of primary care physicians towards the use of a drug formulary- preliminary results of a study in Germany. Int $\sqrt{ }$ Clin Pharmacol Ther 1994 32; 400-2 
- Koomen JM. Woekeren met je "evoked set en je farmacotherapeutisch redeneervermogen. Pharm Weekbl 1998; 133: 1569 - 74

- Koomen JM. Hoe kan de geneesmiddelenkeuze worden geoptimaliseerd?

Med Cont 1998; 53: $1302-5$

- Langley PC. The role of pharmacoeconomic guidelines for formulary approval; the Australian experience. Clin Ther $1993 ; 15 ; 1154-76$ and $1120 \ldots \ldots 142$ - Lexchin $\mathrm{J}$. Improving the appropriateness of physicians prescribing. Int $\mathrm{J}$ Health Serv 1998; $28: 253-67$

- Lexchin J. Interactions between physicians and the pharmaceutical industry: what does the literature say? CMAJ 1993; 149: 1401-7 . . . . . . . . 108 - Lexchin J. Pharmaceutical promotion in Canada: convince them or confuse

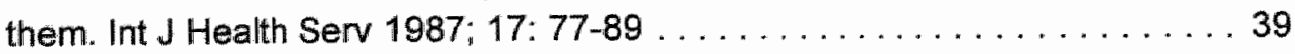
- Little P, Williamson I, Warner G, Gould C, Gantley M, Kinmonth AL. Open randomised trial of prescribing strategies in managing sore throat. BMJ 1997; 314: $722-7$

- Luijn van JCF, Loenhout van JWA, Riteco JA, Ripken T. Toetsing van het geneesmiddelenpakket. Med Cont 1995; (50); 1433-38 . . . . . . . . 125 - Maclure M, Dormuth C, Naumann T, McCormack J, Ragno R, Whiteside C, Wright JM. Influences of educational interventions and adverse news about calcium-channel blockers on first-line prescribing of antihypertensive drugs to elderly people in British Columbia. Lancet 1998; 352: 943-8 . . . . . . 94 - Madhavan S, Amonkar MM, Elliott D, Burke $K_{*}$ Gore P. The gift relationship between pharmaceutical companies and physicians: an exploratory survey of physicians. J Clin Pharm Ther 1997; 22: 207-15 . . . . . . . . . . . 85 - Martin BC, McMillan JA. The impact of implementing a more restrictive prescription limit on Medicaid recipients. Effects on cost, therapy and out-of-pocket expenditures. Med Care 1996; 34, 686-701

- Martin RM, Hilton SR, Kerry SM, Richards NM. General practitioners' perceptions of the tolerability of antidepressant drugs: a comparison of selective serotonin reuptake inhibitors and tricyclic antidepressants. BMJ 1997; 314: 646-5141 - Maxwell M, Howie JG, Pryde CJ. A comparison of three methods of setting prescribing budgets, using data derived from defined daily dose analyses of historic pattern of use. Br J Gen Pract 1998; 48: 1467-72 . . . . . . . 42 - Mazzaglia G, Arcoraci V, Greco S, Cucinotta G, Cazzola M, Caputi AP. Prescribing habits of general practitioners in choosing an empirical antibiotic regimen for lower respiratory tract infections in adults in Sicily. Pharmacol Res $1999 ; 40: 47-52$ 
- McGavock $\mathrm{H}$, Webb $\mathrm{CH}$, Johnston G, Milligan E. Market penetration of new drugs in one United kingdom region: implications for general practitioners and administrators. BMJ $1993(307): 1118-20 \ldots \ldots \ldots \ldots \ldots . \ldots \ldots 2$ - Mehta SS, Wilcox CS, Schulman KA. Treatment of hypertension in patients with comorbidities: results from the study of hypertensive perscribing practices

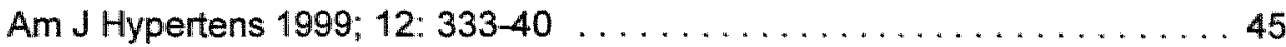
- Miller F, Jacques A, Brailovsky C, Sindon A, Bordage G. When to recommend compulsory versus optional CME programs? A study to establish criteria. Acad Med; 1997 (72): 760-4

96

- Miller E, MacKeigan LD, Rosser W, Marshman J. Effects of perceived patient demand on prescribing anti-infective drugs. CMAJ 1999 161: 139-42 . . . . 46 - Montanaro N, Magrini N, Vaccheri A, Battilana M. Drug utilization in general practice: prescribing habits of National Formulary drugs. Eur J Clin Pharmacol.

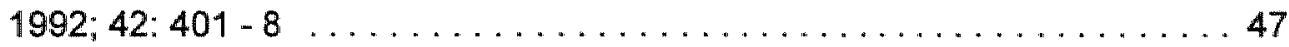

- Morton-Jones T, Pringle M. Explaining variations in prescribing costs across England. BMJ 1993 (306): $1731-4 \ldots \ldots \ldots \ldots \ldots . \ldots \ldots$ - Moser M. Why are physicians not prescribing diuretics more frequently in the management of hypertension? JAMA 1998; 279: 1813-6

- O'Connell D, Henry D, Tomlins R. Randomised controlled trial of effect of feed back on general practitioners' prescribing in Australia.

BMJ 1999; 318: 507-11

- Olesen F, Vedsted P, Norskov-Nielsen J. Change in ranking order of prescribing patterns by age and sex standardization of the practice population-audit may be misleading. Scand I Prim Health Care 1996; 14: 159-64 . . . . . . 50 - Overdyk FJ, Harvey SC, Baldwin D, Rust P, Multani M, Marcell J. Individualized outcome feedback produces voluntary antiemetic prescribing practice changes. J Clin Anesth $1999 ; 11: 17-23 \ldots \ldots \ldots \ldots \ldots \ldots . \ldots . \ldots 90$ - Oxman AD, Thomson MA, Davis DA, Haynes RB. No magic bullets: a systematic review of 102 trials of interventions to improve professional practice. CMAJ 1995 153: $1423-31$

- Penrose A, Dodey $\mathrm{S}$, Tilyard $\mathrm{M}$. Trends in antihypertensive prescribing.

N Z Med J 1996, 109: 4-7 . . . . . . . . . . . . . . . . . . . . . . 52

- Peppin JF. Pharmaceutical sales representatives and physicians: ethical considerations of a relationship. J Med Philos $199621: 83-99 \ldots \ldots$. . . 87

- Peppin JF. An Engelhardtian analysis of interaction between pharmaceutical sales representatives and physicians. J Med Philos 1997 22: 623-41 . . . . 84 
- Petursson $P$. What determines a family doctor's prescribing habits for antibiotics? A comparative study on a doctor's own behaviour in two different settings. Scand J Prim Health Care 1996; 14: 196-202

- Pickering TD, Gurwitz JH, Zaleznik D, Noonan JP, Avorn J. The appropriateness of oral fluoroquinolone-prescribing in the long-term care setting. J Am Geriatr Soc $1994 ; 42: 28-32$

- Popa C, Tomson $Y$, Enfeldt $P$, Bergman U. Prescribing profiles as indicators for rational use of drugs. Eur J Clin Pharmacol 1997; 52[suppl]: A46-69 . . 145 - Rafferty $T$, Wilson-Davis $K$, McGavock H. How has fundholding in Horthern Ireland affected prescribing patterns? A longitudinal study.

BMJ 1997; 315: 166-70

- Rapport van de MDW-werkgroep, Ministerie van Volksgezondheid, Welzijn en Sport, Rijswijk, 1999 140

- Rapport van de BCG B.V. aan Zorgverzekeraars Nederland (BCG-Report), Zeist, 1999

- Rapport van de IWG, Ministerie van Volksgezondheid, Welzijn en Sport, Rijswijk 1994.

- Rapport van de Commissie 'Keuzen in de Zorg' (commissie Dunning): 'Kiezen en delen'. Ministerie van Welzijn, Volksgezondheid en Cultuur,

Rijswijk 1991

- Robinson A. After years of steady growth, winds of restraint blowing on prescription-drug industry. CMAJ 1995; 153: 85-8

- Rolle C, Ferraro L, Marrazzo E, Ostino G. Change in prescribing patterns of general practitioners in ltaly before and after the Reform Drug Act. A case study in the city of Turin. Pharm World Sci 1995; 17: 158-62 160

- Rosholm JU, Gram LF, Isacsson G, Hallas J, Bergman U. Changes in patterns of antidepressant use upon the introduction of the new antidepressants: a prescription database study. Eur J Clin Pharmacol 1997; 52. 205-9 . . . . 54

- Rosmalen CFH, Thomas S. Farmacotherapie voor de huisarts. Achtergronden. Ned. Huisartsen Genootschap, Utrecht 1996 . . . . . . 126 - Rosmalen CFH, Thomas S. Farmacotherapie voor de huisarts; zakboekje. Ned. Huisartsen Genootschap, Utrecht $1996 \ldots \ldots \ldots \ldots \ldots . \ldots . \ldots 62$ - Rothberg AD, Walters L. Formulary and funding implications of the gap between the national Essential Drugs List and current prescribing in a large health maintenance organisation. S Afr Med J 1996; 86:1084 - 90. 
- Roughead EE, Gilbert AL, Primrose JG. Improving drug use: a case study of events which led to changes in use of flucloxacillin in Australia. Soc Sci Med 1999 48: 845-53

- Sacket DL, Rosenberg WMC, Gray JAM Haynes RB, Richardson WS. Evidence based medicine: what it is and what it isn't. BMJ 1996; 312:71-2 . . 156 - Saturno PJ, Palmer RH, Gascon JJ. Physician attitudes, self estimated performance and actual compliance with locally peer-defined quality evaluation criteria. Int J Qual Health Care 1999; 11: 487-49

- Schubert I, Ihle P, Koster I, Ferber von L.1999; Markers to analyse the prescribing of non-steroidal anti-inflammatory drugs in ambulatory care. Eur. J.Clin.Pharmacol. 55: 479-86

- Schuling J, Toenders WGM. Evidence based medicine: betekenis voor de farmacotherapie.Geneesm Bull 1999; 33: $71-7 \ldots \ldots \ldots \ldots \ldots \ldots 127$

- Schwartz JA, Chapman GB. Are more options always better? The attraction effect in physicians' decisions about medications. Med Decis Making 1999; 19(3): 315-23

72

- Sclar DA, Robinson LM, Skaer TL, Galin RS. What factors influence the prescribing of antidepressant pharmacotherapy? An assessment of national office-based encounters. Int J Psychiatry Med 1998; 28: 407-19 . . . . . . . 57 - Seneviratne SL, Gunatilake SB, Adhikari AA, Gunawardhana P, de Silva HJ. Changing prescribing behaviour: early low dose aspirin in suspected acute myocardial infarction. Int J Cardiol 1998; $67: 237-40 \ldots \ldots \ldots . \ldots . \ldots 59$

- Shasha M, Lyons JS, O'Mahoney MT, Rosenberg, Miller SI, Howard KI. Serotonin reuptake inhibitors and the adequacy of antidepressant treatment. Int

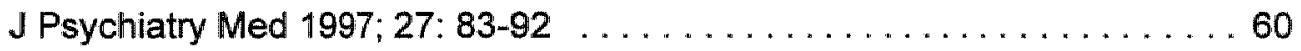

- Spearman ME, Summers K, Moore V, Jacqmin R, Smith G, Groshen S. Cost-effectiveness of initial therapy with 3-hydroxy-3-methylglutaryl coenzyme $A$ reductase inhibitors to treat hypercholesterolemia in a primary care setting of a managed-care organization. Clin Ther 1997; 19:538-9 . . . . . . . . 115

- Statistisch Jaaroverzicht 1996, IMS, Den Haag . . . . . . . . . . . . . . 137

- Steffensen FH, Soresen HT, Olesen F. Diffusion of new drugs in Danish general practice. Fam Pract 1999; 16:407-13 . . . . . . . . . . . . 100 - Steven ID, Wilson DH, Wakefield MA, Beilby J, Coffey GA, Esterman AJ, Golding AP, Graham NM, Litt JC, Rohrsheim RA. 1992; South Australian hypertension survey. General practitioner experiences with drug treatment. Med. J. Australia $156(9): 641-4 \ldots \ldots \ldots \ldots \ldots \ldots . \ldots \ldots$ 
- Stichting Farmaceutische Kengetallen (Foundation for Pharmaceutical Statistics; English text). The Hague / The Netherlands; September 1999 .

- Sylvester SH. General practitioners' attitudes to professional re-accreditation. BMJ 1993; 307: $912-4$

- Taroni F, Stiassi R, Traversa $G$, Raschetti $R$, Mennito-lppolito F, Maggini $M_{\text {, }}$ Spila-Allegiani S. 1990; The nature, content and inter-practice variation of general practice: a regional study in Italy. Eur.J. Epidemiol. 6(3): 313-18 . . . 51 - Tomson $Y$, Wessling A Tomson G. General practitioners for rational use of drugs. Examples from Sweden. Eur J Clin Pharmacol 1994; 47: 213-9 . . . . 61 - Van der Ree CM, Gubbels JW, Goemans LAC, Been P.1999; Een electronisch voorschrijfsysteem. Med.Contact 54(31/32): 1096-9 . . . . . .75 - Van der Ree CM, Mokkink HGA, Van den Hoogen HJM, Grol R. 1998; A therapy decision support system (ETAS) for general practitioners. A pilot study. Huisarts Wet 41/9: 413-5

- Van der Weijden T, Grol RPTM, Knottnerus JA. Feasibility of a national cholesterol guideline in daily practice. A randomized controlled trial in 20 general practices. Int.J.Qual. Health Care 1999; 11: 131-7

- Vries de CS, Duggan CA, Tromp TF, de Jong van den Berg LT Changing prescribing in the light of tolerability concerns: how is this best achieved?

Drug Saf 1999; 21 : 153-60

- Vries de CS, Berg van den PB, Timmer JW, Reicher A, Blijleven W, Tromp ThF.J, Jong de-van de Berg LTW.1999; Prescription data as a tool in pharmacology audit (II): the development of an instrument.

Pharm. World Sci. 21(2): 85-90

- Vries de CS, van Diepen NM, Tromp TF, de Jong van den berg LT. Auditing GP's prescribing habits: cardiovascular prescribing frequently continues medication initiated by specialists. Eur J Clin Pharmacol 1996; 50:349-52 . . . . 63 - Vries de CS, Tromp TF, Blijleven W, de Jong van den Berg LT. Prescription data as a tool in pharmacotherapy audit (1). General considerations. Pharm World Sci 1999; $21: 80-4$

- Vries de TPGM. Presenting clinical pharmacology and therapeutics: general introduction. Br J Clin Pharmac 1993; 35: 577-9

- Vries de TP, Henning RH, Hogerzeil HV, Bapna JS, Bero L, Kafle KK, Mabadeje Af, Santoso B, Smith AJ. Impact of short course in pharmacology for undergraduate medical students; an international randomised controlled study. Lancet $1995,346: 1454-7$ 
- Walzak D, Swindells S, Bhardwaj A. Primary care physicians and the cost of drugs: a study of prescribing practices based on recognition and information sources. J Clin Pharmacol 1994; 34: $1159-63 \ldots \ldots \ldots . \ldots . \ldots 66$ - Weiss MC, Fitspatrick R, Scott DK, Goldacre MJ. Pressures on the general practitioner and decisions to prescribe. Fam Pract 1996; 13:432-8 . . . .67 67 - Wierenga B, Jong SJ, Mantel AF. The decision making process of family physician in choosing a drug. NTvG $1989133115-22 \ldots \ldots .6 .668$ - Wilson RP, Hatcher J, Barton S, Walley T. Influences of practice characteristics on prescribing in fundholding and non-fundholding general practices; an observational study. BMJ 1996; $313: 595-9 \ldots \ldots \ldots \ldots . \ldots . \ldots 69$ - Wyatt TD, Passmore CM, Morrow NC, Reilly PM. Antibiotic prescribing: the need for a policy in general practice. BMJ 1990; 300:441-4 . . . . . . . 70 - Wyatt TD, Reilly PM, Morrow NC, Passmore CM. Short-lived effects of a formulary on anti-infective prescribing - the need for continuing peer review? Fam Pract 1992; 9: 461-5 . . . . . . . . . . . . . . . . . . . . . 71

- Wyatt J, Walton R. Computer based prescribing. BMJ 1995; 311: 1181-2 153 - Yeo GT, de Burgh SP, Letton T, Shaw J, Donnelly N, Swinburn ME, Phillips S, Bridges-Webb C, Mant A. Educational visiting and hypno-sedative prescribing in general practice. Fam Pract $1994 ; 11: 57-61$ 
table 2.1. general practitioners: age, gender, attitude, professional education, own experience with drugs, inter-doctor variations, routine behaviour. page 43

table 2.2. drugs: efficacy, safety, introduction of new drugs, listing / delisting / reimbursement, costs. page 59

table 2.3. prescription: formulary, electronic/computerised prescribing system, discomfort in prescribing, feedback on prescription figures, specialists' prescriptions, (un)awareness in prescribing, quality in prescribing. page 78

table 2.4. information: evidence based medicine, medical audit, guidelines and protocols, pharmaceutical companies, pharmacists. page 90

table 2.5. patients: age of patients, patients' demands, patients' satisfaction and complaints. page 103 


\begin{tabular}{|c|c|c|c|c|c|}
\hline ref. & year & objective & setting & design & results / comments \\
\hline \multicolumn{6}{|l|}{ age } \\
\hline 3 & 1997 & $\begin{array}{l}\text { to bring comput- } \\
\text { erised claims to- } \\
\text { gether with ex- } \\
\text { plicit criteria for } \\
\text { appropriate pre- } \\
\text { scribing in order } \\
\text { to assess } \\
\text { (in)appropriatene } \\
\text { ss and associate } \\
\text { it with defined } \\
\text { physician charac- } \\
\text { teristics }\end{array}$ & $\begin{array}{l}\text { a universal } \\
\text { and com- } \\
\text { prehensive } \\
\text { drug bene- } \\
\text { fit plan for } \\
\text { the elderly }\end{array}$ & $\begin{array}{l}\text { analysis of } \\
\text { computer- } \\
\text { ised claims }\end{array}$ & $\begin{array}{l}\text { the rate of potentially inap- } \\
\text { propriate drug receiving by } \\
\text { elderly patients was: } 38 \% \\
\text { for antidepressants, } 19 \% \\
\text { for oral hypoglycaemics, } \\
18 \% \text { for anti-inflammatory } \\
\text { drugs; older physicians } \\
\text { and physicians without } \\
\text { speciallity certification were } \\
\text { more likely to prescribe } \\
\text { potentially inappropriate } \\
\text { drugs; drug claims data- } \\
\text { bases can be used to pro- } \\
\text { vide an overview of pre- } \\
\text { scribing problems at a } \\
\text { population level and can } \\
\text { reveal physician character- } \\
\text { istics, however linking to } \\
\text { more clinical details is nec- } \\
\text { essary for a more definitive } \\
\text { measure of appropriate- } \\
\text { ness. }\end{array}$ \\
\hline 26 & 1985 & $\begin{array}{l}\text { to dettermine the } \\
\text { extent to which } \\
\text { GPs would partic- } \\
\text { ipate in quality } \\
\text { assessment activ- } \\
\text { ities based on } \\
\text { objective evi- } \\
\text { dence of perfor- } \\
\text { mance and the } \\
\text { personal and pro- } \\
\text { fessional charac- } \\
\text { teristics of inter- } \\
\text { ested doctors }\end{array}$ & $\begin{array}{l}\text { UK } \\
\text { Leicestersh } \\
\text { ire and } \\
\text { Lincolnshir } \\
\text { e }\end{array}$ & $\begin{array}{l}508 \text { replies } \\
\text { on } 669 \\
\text { questionna } \\
\text { ires }\end{array}$ & $\begin{array}{l}\text { highest response rates } \\
\text { were recorded by trainers, } \\
\text { principals and younger } \\
\text { doctors; lowest by over- } \\
\text { seas graduates and older } \\
\text { doctors; most enthusiastic } \\
\text { and active groups were } \\
\text { trainers, principals in train- } \\
\text { ing practices and members } \\
\text { or fellows of the RCGP, } \\
\text { younger doctors, vocation- } \\
\text { ally trained doctors, princi- } \\
\text { pals in large group prac- } \\
\text { tices. }\end{array}$ \\
\hline
\end{tabular}




\begin{tabular}{|c|c|c|c|c|c|}
\hline 45 & 1999 & $\begin{array}{l}\text { to survey primary } \\
\text { care physicians' } \\
\text { antihypertensive } \\
\text { prescribing prac- } \\
\text { tices and their } \\
\text { treatment } \\
\text { recommenda- } \\
\text { tions for patients } \\
\text { with comorbidities }\end{array}$ & $\begin{array}{l}\text { US of } \\
\text { America } \\
\text { over } 18 \\
\text { months }\end{array}$ & $\begin{array}{l}\text { a direct } \\
\text { mail survey } \\
\text { sent to a } \\
\text { national } \\
\text { random } \\
\text { sample of } \\
\text { doctors }\end{array}$ & $\begin{array}{l}\text { ACE-inhibitors increased } \\
\text { in patients with congestive } \\
\text { heart fallure and diabetes; } \\
\text { beta-blockers increased } \\
\text { for patients with a history } \\
\text { of Ml; physicians did not } \\
\text { follow JNC recommenda- } \\
\text { tions for black patients, } \\
\text { older patients or those with } \\
\text { mill renal failure; more } \\
\text { prescribing was in line with } \\
\text { JNC recommendations } \\
\text { after } 19 \text { months; younger } \\
\text { physicians were more } \\
\text { likely to prescribe agents } \\
\text { consistent with the guide- } \\
\text { lines }\end{array}$ \\
\hline 59 & 1998 & $\begin{array}{l}\text { to assess the ef- } \\
\text { fectiveness of } \\
\text { intervention, } \\
\text { aimed at chang- } \\
\text { ing prescribing } \\
\text { behaviour of GPs } \\
\text { with regard to } \\
\text { early low dose } \\
\text { aspirin in patients } \\
\text { with suspected } \\
\text { acute Mi }\end{array}$ & $96 \mathrm{GPS}$ & $\begin{array}{l}3 \text { question- } \\
\text { naires sent } \\
\text { in month } 1 \text {, } \\
8 \text { and } 11 \\
\text { with an } \\
\text { interven- } \\
\text { tion } \\
\text { between } \\
\text { the last two } \\
\text { questionna } \\
\text { ir-es }\end{array}$ & $\begin{array}{l}\text { an intensive, personal in- } \\
\text { tervention achieved suc- } \\
\text { cess in changing prescrib- } \\
\text { ing behaviour, success in } \\
\text { GPs }<40 y \text { was greater } \\
\text { than in those }>40 y \text { dis- } \\
\text { semination of information } \\
\text { on new practices in medi- } \\
\text { cine are important in the } \\
\text { process of CME for doc- } \\
\text { tors }\end{array}$ \\
\hline 79 & 1995 & $\begin{array}{l}\text { interactions with } \\
\text { pharmaceutical } \\
\text { industry }\end{array}$ & $\begin{array}{l}74 \text { of } 109 \\
\text { residents, } \\
\text { interns and } \\
\text { clerks in } \\
\text { training in } \\
\text { psychiaitry }\end{array}$ & $\begin{array}{l}\text { questionna } \\
\text { ir. }\end{array}$ & $\begin{array}{l}\text { junior residents attended } \\
\text { more drug lunches than } \\
\text { senior residents; signifi- } \\
\text { cantly more junior resi- } \\
\text { dents felt that pharmaceu- } \\
\text { tical representatives have } \\
\text { a valuable teaching role }\end{array}$ \\
\hline 103 & 1993 & $\begin{array}{l}\text { to find out why } \\
\text { the response rate } \\
\text { to requests to } \\
\text { GPs to supply } \\
\text { post-marketing } \\
\text { data on new } \\
\text { drugs has been } \\
\text { falling }\end{array}$ & $\begin{array}{l}543788 \\
\text { treatments } \\
\text { with } 27 \\
\text { PEM- } \\
\text { drugs. } \\
1984-9 \text { by } \\
28,402 \\
\text { GPs in } \\
\text { England }\end{array}$ & $\begin{array}{l}\text { reviewing } \\
\text { dispensing } \\
\text { data }\end{array}$ & $\begin{array}{l}\text { more younger doctors } \\
\text { were among the low pre- } \\
\text { scribers }\end{array}$ \\
\hline
\end{tabular}




\begin{tabular}{|c|c|c|c|c|c|}
\hline 179 & 1994 & $\begin{array}{l}\text { relation between } \\
\text { GPs' characteris- } \\
\text { tics and prescrib- } \\
\text { ing for elderly pa- } \\
\text { tients }\end{array}$ & $376 \mathrm{GPs}$ & $\begin{array}{l}\text { linking } 2 \\
\text { provincial } \\
\text { databases }\end{array}$ & $\begin{array}{l}\text { high prescribers and low } \\
\text { prescribers do not signif- } \\
\text { cantly differ in age }\end{array}$ \\
\hline \multicolumn{6}{|c|}{ gender } \\
\hline 100 & 1999 & $\begin{array}{l}\text { diffusion of new } \\
\text { drugs in general } \\
\text { practice }\end{array}$ & $\begin{array}{l}\text { five new } \\
\text { drugs in } \\
\text { North } \\
\text { Jutland } \\
\text { County } \\
(490.000 \\
\text { inh.) pres- } \\
\text { cribed by } \\
95 \text { solo } \\
\text { practitionirs }\end{array}$ & $\begin{array}{l}\text { prescrip- } \\
\text { tions identi- } \\
\text { fied in pre- } \\
\text { scription } \\
\text { database }\end{array}$ & $\begin{array}{l}\text { late prescribing of } \\
\text { tramadol was associated } \\
\text { with female physicians }\end{array}$ \\
\hline 103 & 1993 & $\begin{array}{l}\text { to find out why } \\
\text { the response rate } \\
\text { to requests to } \\
\text { GPs to supply } \\
\text { post-marketing } \\
\text { data on new } \\
\text { drugls has been } \\
\text { falling }\end{array}$ & $\begin{array}{l}543,788 \\
\text { treatments } \\
\text { with } 27 \\
\text { PEM- } \\
\text { drugs; } \\
1984-9 \text { by } \\
28,402 \\
\text { GPs in } \\
\text { England }\end{array}$ & $\begin{array}{l}\text { reviewing } \\
\text { dispensing } \\
\text { data }\end{array}$ & $\begin{array}{l}46 \% \text { of the doctors that did } \\
\text { not prescribe any of the } \\
\text { drugs were female; } 9 \% \text { of } \\
\text { the heavy prescribers were } \\
\text { female }\end{array}$ \\
\hline 179 & 1994 & $\begin{array}{l}\text { relation between } \\
\text { GPs' characteris- } \\
\text { tics and prescrib- } \\
\text { ing for elderly pa- } \\
\text { tients }\end{array}$ & $376 \mathrm{GPs}$ & $\begin{array}{l}\text { linking } 2 \\
\text { regional } \\
\text { databases }\end{array}$ & $\begin{array}{l}\text { high prescribers are more } \\
\text { likely to be male }\end{array}$ \\
\hline
\end{tabular}




\begin{tabular}{|c|c|c|c|c|c|}
\hline \multicolumn{6}{|c|}{ attitude } \\
\hline 79 & 1995 & $\begin{array}{l}\text { to examine the } \\
\text { type and number } \\
\text { of interactions of } \\
\text { doctors with sales } \\
\text { representatives of } \\
\text { pharmaceutical } \\
\text { companies and } \\
\text { the attitudes of } \\
\text { physicians in } \\
\text { training towards } \\
\text { these interactions }\end{array}$ & $\begin{array}{l}7 \text { teaching } \\
\text { hospitals } \\
\text { affiliated } \\
\text { with the } \\
\text { Depart- } \\
\text { ment of } \\
\text { Psychiatry. } \\
\text { University } \\
\text { of Toronto } \\
10-1993 \text { till } \\
2-1994\end{array}$ & $\begin{array}{l}\text { self report } \\
\text { question- } \\
\text { naire }\end{array}$ & $\begin{array}{l}\text { interactions between medi- } \\
\text { call representatives of - } \\
\text { pharmaceutical companies } \\
\text { and the doctors in the } \\
\text { study were common and } \\
\text { many of them disavowed } \\
\text { the potential of these inter- } \\
\text { actions to influence pre- } \\
\text { scribing; } \\
\text { the physicians in training } \\
\text { perceived little eduicational } \\
\text { value; } 71 \% \text { disagreed with } \\
\text { banning medical represen- } \\
\text { tatives from making } \\
\text { presentations; } \\
\text { fewer than half would } \\
\text { maintain the same degree } \\
\text { of contact with medical } \\
\text { representatives if they did } \\
\text { not receive promotional } \\
\text { gifts; the more money and } \\
\text { promotional items a phy- } \\
\text { sician in training had re- } \\
\text { ceived, the more likely } \\
\text { he/she believed that dis- } \\
\text { cussions with medical rep- } \\
\text { resentatives did not affect } \\
\text { prescribing }\end{array}$ \\
\hline
\end{tabular}




\begin{tabular}{|c|c|c|c|c|c|}
\hline 85 & 1997 & $\begin{array}{l}\text { to survey physi- } \\
\text { cians" attitudes } \\
\text { surrounding the } \\
\text { "gift relationship" } \\
\text { between pharma- } \\
\text { ceutical compa- } \\
\text { nies and physi- } \\
\text { cians }\end{array}$ & $\begin{array}{l}\text { West Vir- } \\
\text { ginia, } 283 \\
\text { responses } \\
\text { on } 1000 \\
\text { mailled sur- } \\
\text { veys }\end{array}$ & survey & $\begin{array}{l}\text { physicians slightly agreed, } \\
\text { that PCs give gifts to phy- } \\
\text { sicians to influence their } \\
\text { prescribing and that PCs' } \\
\text { sponsoring of CME-pro- } \\
\text { grammes are only promo- } \\
\text { tional gimmicks and that it } \\
\text { may be inappropriate to } \\
\text { accept gifts from PCs; } \\
\text { moderately disagreed that } \\
\text { they do so as a form of } \\
\text { professional recognition of } \\
\text { physicians; strongly dis- } \\
\text { agree, that their behaviour } \\
\text { could be influenced by the } \\
\text { gifts they receive; they } \\
\text { seemed slightly averse to } \\
\text { having their relationship } \\
\text { made public; correlation } \\
\text { analysis showed a greater } \\
\text { likeliness of physicians to } \\
\text { be offered gifts the larger } \\
\text { the number of patients, } \\
\text { patients per day and pre- } \\
\text { scriptions per day; the lat- } \\
\text { ter physicians are also } \\
\text { more likely to condone the } \\
\text { practice of gifts giving and } \\
\text { receiving }\end{array}$ \\
\hline 100 & 1999 & $\begin{array}{l}\text { diffusion of new } \\
\text { drugs in general } \\
\text { practice }\end{array}$ & $\begin{array}{l}\text { five new } \\
\text { drugs in } \\
\text { North } \\
\text { Jutland } \\
\text { County } \\
\text { ( } 490.000 \\
\text { inhabi- } \\
\text { tants) pre- } \\
\text { scribed by } \\
95 \text { solo } \\
\text { practitio- } \\
\text { ners }\end{array}$ & $\begin{array}{l}\text { prescrip- } \\
\text { tions identi- } \\
\text { fied in pre- } \\
\text { scription } \\
\text { database }\end{array}$ & $\begin{array}{l}\text { late prescribers share } \\
\text { some common character- } \\
\text { istics, such as a strong } \\
\text { general restrictive altitude } \\
\text { to pharmaco-therapy }\end{array}$ \\
\hline
\end{tabular}




\begin{tabular}{|c|c|c|c|c|c|}
\hline $\begin{array}{l}103 \\
\text { and } \\
\text { let- } \\
\text { ters }\end{array}$ & 1993 & $\begin{array}{l}\text { to find out why } \\
\text { the response rate } \\
\text { to requests to } \\
\text { GPs to supply } \\
\text { post-marketing } \\
\text { data on new } \\
\text { drugs has been } \\
\text { falling }\end{array}$ & $\begin{array}{l}543788 \\
\text { treatrnents } \\
\text { with } 27 \\
\text { PEM- } \\
\text { drugs; } \\
1984-9 \text { by } \\
28402 \\
\text { GPs in } \\
\text { England }\end{array}$ & $\begin{array}{l}\text { reviewing } \\
\text { dispensing } \\
\text { data }\end{array}$ & $\begin{array}{l}\text { In the UK, the Netherlands } \\
\text { and Germany few heavy } \\
\text { prescribing GPS cause a } \\
\text { disproportionate share of } \\
\text { prescriptions for new drugs }\end{array}$ \\
\hline 105 & 1997 & $\begin{array}{l}\text { assess the } \\
\text { awareness of re- } \\
\text { porting Adverse } \\
\text { Drug Reactions } \\
\text { (ADRs) and iden- } \\
\text { tify reasons for } \\
\text { under reporting }\end{array}$ & $\begin{array}{l}350 \text { GPS } \\
\text { were in- } \\
\text { vited to } \\
\text { react, } 207 \\
(59 \%) \text { re- } \\
\text { spondents }\end{array}$ & $\begin{array}{l}\text { question- } \\
\text { naires } \\
\text { aboul }\end{array}$ & $\begin{array}{l}77 \% \text { of the respondent } \\
\text { GPs stated to have noticed } \\
\text { ADRs and mainly reported } \\
\text { to pharmaceutical manu- } \\
\text { facturers, } 50 \% \text { did not re- } \\
\text { port ADRs to anyone }\end{array}$ \\
\hline \multicolumn{6}{|c|}{ professional education } \\
\hline 2 & 1997 & $\begin{array}{l}\text { to describe the } \\
\text { complete range of } \\
\text { factors which doc- } \\
\text { tors recognise as } \\
\text { changing their } \\
\text { clinical practice } \\
\text { and provide a } \\
\text { measure of how } \\
\text { often education is } \\
\text { invalved in } \\
\text { change }\end{array}$ & $\begin{array}{l}361 \text { chang- } \\
\text { es with an } \\
\text { average of } \\
3.0 \text { rea- } \\
\text { sons per } \\
\text { change in } \\
\text { primary } \\
\text { and sec- } \\
\text { ondary } \\
\text { care }\end{array}$ & interviews & $\begin{array}{l}\text { education is involved in } \\
\text { about a third of changes in } \\
\text { clinical practice, among } \\
\text { which prescribing } \\
\text { changes; other reasons } \\
\text { were organisational factors } \\
\text { and contact with profes- } \\
\text { sionals }\end{array}$ \\
\hline 20 & 1995 & $\begin{array}{l}\text { to develop and } \\
\text { evaluate a } \\
\text { producer-inde- } \\
\text { pendent, problem } \\
\text { oriented, face to } \\
\text { face, small-group } \\
\text { education } \\
\text { programme on } \\
\text { drug treatment in } \\
\text { primary health } \\
\text { care }\end{array}$ & $\begin{array}{l}\text { southern } \\
\text { Swedish } \\
\text { health care } \\
\text { region over } \\
\text { a } 10 \text { year } \\
\text { period }\end{array}$ & $\begin{array}{l}\text { voluntary } \\
\text { regiistration } \\
\text { of prescrip- } \\
\text { tion (antibi- } \\
\text { otics), re- } \\
\text { gional pre- } \\
\text { scription } \\
\text { analyses } \\
\text { and analy- } \\
\text { ses of drug } \\
\text { sales data }\end{array}$ & $\begin{array}{l}\text { significant, consistent and } \\
\text { sustained changes in pre- } \\
\text { scribing were seen along } \\
\text { with the education } \\
\text { programme }\end{array}$ \\
\hline
\end{tabular}




\begin{tabular}{|c|c|c|c|c|c|}
\hline 34 & 1999 & $\begin{array}{l}\text { to assess the ef- } \\
\text { fectiveness of a } \\
\text { mailed interven- } \\
\text { tion combining } \\
\text { confidential pre- } \\
\text { scribing feedback } \\
\text { with targeted edu- } \\
\text { cational bulletins } \\
\text { in increasing the } \\
\text { use of less ex- } \\
\text { pensive, fist-line } \\
\text { antibiotics by GPS }\end{array}$ & $\begin{array}{l}251 \mathrm{GPs} \\
\text { from } \\
\text { Southern } \\
\text { Ontario: } \\
135 \text { inter- } \\
\text { vention } \\
\text { and } 116 \text { in } \\
\text { control } \\
\text { group }\end{array}$ & & $\begin{array}{l}\text { prescribing data were col- } \\
\text { lected from the claims da- } \\
\text { tabase; feedback took } \\
\text { place every } 2-6 \text { months; } \\
\text { cosits rose in the control } \\
\text { group and remained con- } \\
\text { stant in the feedback- } \\
\text { group; first-line drug use } \\
\text { increased in the feedback } \\
\text { group but decreased in the } \\
\text { feedback group; } 82 \% \text { of the } \\
\text { GPs in the feed back } \\
\text { group would readily partici- } \\
\text { pate in another, similar } \\
\text { program }\end{array}$ \\
\hline 59 & 1998 & $\begin{array}{l}\text { to assess the ef- } \\
\text { fectiveness of } \\
\text { intervention. } \\
\text { aimed at chang- } \\
\text { ing prescribing } \\
\text { behaviour of GPs } \\
\text { with regard to } \\
\text { early low dose } \\
\text { aspirin in patients } \\
\text { with suspected } \\
\text { acute MI }\end{array}$ & $96 \mathrm{GPs}$ & $\begin{array}{l}3 \text { question- } \\
\text { naires sent } \\
\text { in month } 1 \text {, } \\
8 \text { and } 11 \\
\text { with an } \\
\text { interven- } \\
\text { tion } \\
\text { between } \\
\text { the last two } \\
\text { question- } \\
\text { naires }\end{array}$ & $\begin{array}{l}\text { an intensive, personal in- } \\
\text { tervention achieved suc- } \\
\text { cess in changing prescrib- } \\
\text { ing bethaviour, dissemina- } \\
\text { tion of information on new } \\
\text { practices in medicine are } \\
\text { importan in the process of } \\
\text { CME for doctors. }\end{array}$ \\
\hline 65 & 1995 & $\begin{array}{l}\text { to prevent irratio- } \\
\text { nal prescribing } \\
\text { becoming a habit }\end{array}$ & $\begin{array}{l}219 \text { under- } \\
\text { graduate } \\
\text { medical } \\
\text { students in } \\
7 \text { different } \\
\text { cities all } \\
\text { over the } \\
\text { world }\end{array}$ & $\begin{array}{l}\text { controlled } \\
\text { measuring } \\
\text { of the im- } \\
\text { pact of a } \\
\text { short } \\
\text { problem- } \\
\text { based } \\
\text { training } \\
\text { course by } \\
\text { tests be- } \\
\text { fore, imme- } \\
\text { diately af- } \\
\text { ter and six } \\
\text { months } \\
\text { later }\end{array}$ & $\begin{array}{l}\text { the study group performed } \\
\text { significantly better in all } \\
\text { (old and new) patient prob- } \\
\text { lems; this approach } \\
\text { seemed to be an efficient } \\
\text { way of teaching rational } \\
\text { prescribing; a change in } \\
\text { teaching methods is pro- } \\
\text { posed, away from transfer- } \\
\text { ring knowledge on the } \\
\text { thousands of drugs avall- } \\
\text { able towards problem } \\
\text { based teaching of thera- } \\
\text { peutic reasoning }\end{array}$ \\
\hline
\end{tabular}




\begin{tabular}{|c|c|c|c|c|c|}
\hline 92 & 1995 & $\begin{array}{l}\text { determine the } \\
\text { effectiveness of } \\
\text { different types of } \\
\text { interventions in } \\
\text { improwing health } \\
\text { professional per- } \\
\text { formance and } \\
\text { health outcomes }\end{array}$ & $\begin{array}{l}102 \text { trials } \\
\text { included } \\
\text { after } \\
\text { search }\end{array}$ & $\begin{array}{l}\text { interna- } \\
\text { tional liter- } \\
\text { ature } \\
\text { seanch } \\
1970- \\
1993\end{array}$ & $\begin{array}{l}\text { dissemination-onlly strate- } \\
\text { gies caused little or no } \\
\text { changes; more complex } \\
\text { interventions such as out- } \\
\text { reach visits or local opin- } \\
\text { ion leaders were most of- } \\
\text { ten moderately effective }\end{array}$ \\
\hline 93 & 1995 & $\begin{array}{l}\text { to study the effect } \\
\text { off "academic } \\
\text { group detailing" } \\
\text { on prescribing } \\
\text { lipid-lowering } \\
\text { drugs }\end{array}$ & $\begin{array}{l}134 \text { com- } \\
\text { munity } \\
\text { health cen- } \\
\text { tres in } \\
\text { Swedish } \\
\text { primary } \\
\text { care }\end{array}$ & $\begin{array}{l}\text { interventio } \\
\text { n-vs } \\
\text { control- } \\
\text { group }\end{array}$ & $\begin{array}{l}\text { prescription in the } \\
\text { intervention-group in- } \\
\text { creased } 20 \% \text { and the in- } \\
\text { crease was statistically } \\
\text { different from the corre- } \\
\text { sponding change in the } \\
\text { control-group }\end{array}$ \\
\hline 96 & 1997 & $\begin{array}{l}\text { a study to estab- } \\
\text { lish criteria for } \\
\text { compulsory / op- } \\
\text { tional continuing } \\
\text { medical educa- } \\
\text { tion }\end{array}$ & $\begin{array}{l}\text { to } 14 \text { phy- } \\
\text { sicians in } \\
\text { Quebec } \\
\text { standard- } \\
\text { ized clinical } \\
\text { cases were } \\
\text { presented }\end{array}$ & $\begin{array}{l}12 \text { external } \\
\text { judges re- } \\
\text { viewing } 14 \\
\text { structured } \\
\text { oral inter- } \\
\text { views and } \\
\text { liniking } \\
\text { them to ten } \\
\text { aspects of } \\
\text { com- } \\
\text { petence }\end{array}$ & $\begin{array}{l}\text { the judges corroborated } \\
\text { the decisions previously } \\
\text { made by the College of } \\
\text { Physicians of Quebec }\end{array}$ \\
\hline 105 & 1997 & $\begin{array}{l}\text { assess the } \\
\text { awareness of re- } \\
\text { porting Adverse } \\
\text { Drug Reactions } \\
\text { (ADRs) and iden- } \\
\text { tify reasons for } \\
\text { under reporting }\end{array}$ & $\begin{array}{l}350 \text { GPs } \\
\text { were in- } \\
\text { vited to } \\
\text { react, } 207 \\
(59 \%) \text { re- } \\
\text { spondents }\end{array}$ & $\begin{array}{l}\text { question- } \\
\text { naires } \\
\text { about }\end{array}$ & $\begin{array}{l}\text { the knowledge about re- } \\
\text { porting( why and what) } \\
\text { was little; measures to im- } \\
\text { prove the situation are pro- } \\
\text { posed }\end{array}$ \\
\hline 107 & 1994 & $\begin{array}{l}\text { promoting rational } \\
\text { prescribing on } \\
\text { behalf of hyp- } \\
\text { nosedative drugs }\end{array}$ & $\begin{array}{l}137 \text { GPs in } \\
\text { New South } \\
\text { Wales }\end{array}$ & $\begin{array}{l}\text { controlled } \\
\text { trial of an } \\
\text { educa- } \\
\text { tional inter- } \\
\text { vention }\end{array}$ & $\begin{array}{l}\text { changes in prescribing } \\
\text { behaviour had no correla- } \\
\text { tion with any of the pro- } \\
\text { cess measures }\end{array}$ \\
\hline
\end{tabular}




\begin{tabular}{|c|c|c|c|c|c|}
\hline 109 & 1993 & $\begin{array}{l}\text { to determine the } \\
\text { views of GPS } \\
\text { about profes- } \\
\text { sional } \\
\text { reaccreditation }\end{array}$ & $\begin{array}{l}210 \text { re- } \\
\text { sponding } \\
\text { GPs out of } \\
278\end{array}$ & $\begin{array}{l}\text { question- } \\
\text { naire }\end{array}$ & $\begin{array}{l}\text { most GPs support protes- } \\
\text { sional reaccreditation. } \\
\text { They believe the process } \\
\text { shoull be led by the pro- } \\
\text { fession, be educational } \\
\text { and take account of a } \\
\text { range of professional ac- } \\
\text { tivities; prescribing prac- } \\
\text { tices were among the most } \\
\text { popular subjects for scru- } \\
\text { tiny }(67 \%)\end{array}$ \\
\hline \multicolumn{6}{|c|}{ own experience with drugs } \\
\hline 4 & 1996 & $\begin{array}{l}\text { to explore GPs' } \\
\text { reasons for recent } \\
\text { changes in their } \\
\text { prescribing be- } \\
\text { haviour }\end{array}$ & $\begin{array}{l}18 \text { GPs in } \\
\text { general } \\
\text { practices in } \\
\text { south east } \\
\text { London. } \\
\text { UK }\end{array}$ & $\begin{array}{l}\text { qualitative } \\
\text { analysis of } \\
\text { semi-struc- } \\
\text { tured inter- } \\
\text { views over } \\
\text { prescribing } \\
\text { in the pre- } \\
\text { ceding } 6 \\
\text { months }\end{array}$ & $\begin{array}{l}\text { the most frequently men- } \\
\text { tioned changes related to } \\
\text { fluoxetine, ACE-inhibitors, } \\
\text { and antibiotic treatment of } \\
\text { Helicobacter pylori; } 3 \text { mod- } \\
\text { els were identified: accu- } \\
\text { mulation (following wolume } \\
\text { and authority of evidence), } \\
\text { challenge (following a dra- } \\
\text { matic or conflictual clinical } \\
\text { event) and continuity (in a } \\
\text { background of willingness } \\
\text { to change, cost pressures } \\
\text { and comprehensible action } \\
\text { of drug)) model, which } \\
\text { have important implica- } \\
\text { tions for the design and } \\
\text { evaluation of interventions } \\
\text { aimed at change of } \\
\text { behaviour }\end{array}$ \\
\hline 105 & 1997 & $\begin{array}{l}\text { assess the } \\
\text { awareness of re- } \\
\text { porting Adverse } \\
\text { Drug Reactions } \\
\text { (ADRs) and iden- } \\
\text { tify reasons for } \\
\text { under reporting }\end{array}$ & $\begin{array}{l}350 \mathrm{GPs} \\
\text { were in- } \\
\text { vited to } \\
\text { react, } 207 \\
(59 \%) \text { re- } \\
\text { spondents }\end{array}$ & $\begin{array}{l}\text { question- } \\
\text { naires }\end{array}$ & $\begin{array}{l}77 \% \text { of the GPs stated to } \\
\text { have noticed ADRs and } \\
\text { mainly reported to pharma- } \\
\text { ceutical manufacturers, } \\
50 \% \text { did not report ADRs } \\
\text { to anyone, unusulal or se- } \\
\text { vere ADRs andior new } \\
\text { drugs are important fac- } \\
\text { tors to report: not reported } \\
\text { ADRs were judged clinical } \\
\text { negligible; the knowledge } \\
\text { about reporting( why and } \\
\text { what) was little }\end{array}$ \\
\hline
\end{tabular}




\begin{tabular}{|c|c|c|c|c|c|}
\hline \multicolumn{6}{|c|}{ interdoctor-variations / personality } \\
\hline 9 & 1990 & $\begin{array}{l}\text { to compare the } \\
\text { prescribing prac- } \\
\text { tices among fam- } \\
\text { ily practice, pedi- } \\
\text { atric and intemal } \\
\text { medicine third } \\
\text { year residents }\end{array}$ & $\begin{array}{l}\text { inner city } \\
\text { ambulatory } \\
\text { care set- } \\
\text { ting }\end{array}$ & $\begin{array}{l}\text { a four- } \\
\text { month } \\
\text { chart audit } \\
\text { for pre- } \\
\text { scriptions } \\
\text { for four } \\
\text { different } \\
\text { diagnoses }\end{array}$ & $\begin{array}{l}\text { prescribed medications } \\
\text { differed not between the } \\
\text { groups, but there were } \\
\text { differences in the number } \\
\text { of visits and prescriptions } \\
\text { among the specialties, the } \\
\text { prescribing practices of the } \\
\text { study group differed from a } \\
\text { national survey of private } \\
\text { practitioners in several } \\
\text { drug categories }\end{array}$ \\
\hline 10 & 1992 & $\begin{array}{l}\text { to explore the } \\
\text { discomfort experi- } \\
\text { enced by GPs in } \\
\text { relation to deci- } \\
\text { sions about } \\
\text { whether or not to } \\
\text { prescribe }\end{array}$ & $\begin{array}{l}1 \text { family } \\
\text { practitioner } \\
\text { committee } \\
\text { in the north } \\
\text { of England }\end{array}$ & $\begin{array}{l}\text { focussed } \\
\text { interviews } \\
\text { with } 74 \\
\text { respon- } \\
\text { dents (69 } \\
\text { principal } \\
\text { GPs, } 5 \\
\text { trainee } \\
\text { GPs) }\end{array}$ & $\begin{array}{l}\text { any prescribable item and } \\
\text { any condition could be as- } \\
\text { sociatted with discomfort; } \\
\text { patient expectation, clinical } \\
\text { appropriateness, doctor- } \\
\text { patient- relationship-fac- } \\
\text { tors and precedents were } \\
\text { the main reasons for the } \\
\text { decisions made; concern } \\
\text { about drug toxicity, failure } \\
\text { to live up to the GP's own } \\
\text { expectations, concern } \\
\text { about the appropriateness } \\
\text { of treatment, ignorance or } \\
\text { uncertainty were the main } \\
\text { reasons for feeling uncom- } \\
\text { fortable; many consider- } \\
\text { ations (medical, social and } \\
\text { logistic) influence the deci- } \\
\text { sion to prescribe, the final } \\
\text { action depends on a com- } \\
\text { plex interaction of these } \\
\text { disparate influences }\end{array}$ \\
\hline
\end{tabular}




\begin{tabular}{|c|c|c|c|c|c|}
\hline 14 & 1997 & $\begin{array}{l}\text { to examine the } \\
\text { effect of patients' } \\
\text { expectations for } \\
\text { medication and } \\
\text { doctors' percep- } \\
\text { tions of patients } \\
\text { expectations on } \\
\text { prescribing when } \\
\text { patients present } \\
\text { with new condi- } \\
\text { tions }\end{array}$ & $\begin{array}{l}\text { GPs in } \\
\text { Newcastle, } \\
\text { Australia }\end{array}$ & $\begin{array}{l}\text { a question- } \\
\text { naire study } \\
\text { with } 22 \\
\text { non-ran- } \\
\text { domly se- } \\
\text { lected GPs } \\
\text { and } 336 \text { of } \\
\text { their pa- } \\
\text { tients with } \\
\text { a newly } \\
\text { diagnosed } \\
\text { medical } \\
\text { condition }\end{array}$ & $\begin{array}{l}50 \% \text { of the patients re- } \\
\text { ceived a prescription, pa- } \\
\text { tients who expected medi- } \\
\text { cation were nearly three } \\
\text { times more likely to re- } \\
\text { ceive medication; when } \\
\text { the GP thought the patient } \\
\text { expected medication the } \\
\text { patient was } 10 \text { times more } \\
\text { likely to receive it; the doc- } \\
\text { tors opinion about the pa- } \\
\text { tients' expectations were } \\
\text { the strongest determinants } \\
\text { of prescribing }\end{array}$ \\
\hline 17 & 1998 & $\begin{array}{l}\text { to present a re- } \\
\text { view of studies of } \\
\text { prescribing deci- } \\
\text { sions in the last } \\
\text { decade and to } \\
\text { discuss the most } \\
\text { commonly used } \\
\text { strategies }\end{array}$ & & & $\begin{array}{l}\text { much variation between } \\
\text { GPs is seen, sometimes } \\
\text { carefully weighing all pros } \\
\text { and cons, sometimes let- } \\
\text { ting only one aspect de- } \\
\text { termine their choice; be- } \\
\text { sides medical-pharmaceu- } \\
\text { tical other considerations } \\
\text { play an important role; the } \\
\text { decision-making process } \\
\text { in itself should have an } \\
\text { explicit place in (post-grad- } \\
\text { uate) education }\end{array}$ \\
\hline 21 & 1995 & $\begin{array}{l}\text { to measure tacit } \\
\text { policies used by } \\
\text { GPs in prescrib- } \\
\text { ing lipid llowering } \\
\text { agents and to } \\
\text { compare these } \\
\text { with their stated } \\
\text { policies }\end{array}$ & $\begin{array}{l}35 \text { GPs in } \\
\text { the Plym- } \\
\text { outh area, } \\
\text { ranged } \\
\text { from } 31 \text { to } \\
55 \text { years; } \\
\text { all but four } \\
\text { were mem }\end{array}$ & $\begin{array}{l}\text { tacit poli- } \\
\text { cies: rating } \\
130 \text { imagi- } \\
\text { nary cases } \\
\text { presented } \\
\text { by a com- } \\
\text { puter, raw } \\
\text { data were } \\
\text { converted } \\
\text { into statisti- } \\
\text { cal weigh } \\
\text { tings by } \\
\text { use of mul- } \\
\text { tiple linear } \\
\text { regression; } \\
\text { stated poli- } \\
\text { cies: inter- } \\
\text { views }\end{array}$ & $\begin{array}{l}\text { both tacit and stated poill- } \\
\text { cies diverged widely be- } \\
\text { tween different doctors" } \\
\text { doctors' policies are highly } \\
\text { variable and particularly } \\
\text { inconsistent in the treat- } \\
\text { ment of smokers, relevant } \\
\text { risk factors may be ig- } \\
\text { nored, even though they } \\
\text { are understood, because } \\
\text { risk assessment is too psy- } \\
\text { chologically conmplex a } \\
\text { task to be performedl intu- } \\
\text { itively; decision aids and } \\
\text { clear protocols are needed } \\
\text { in this area }\end{array}$ \\
\hline
\end{tabular}




\begin{tabular}{|c|c|c|c|c|c|}
\hline 24 & 1980 & $\begin{array}{l}\text { to develop a } \\
\text { model for cost } \\
\text { effective prescrib- } \\
\text { ing in general } \\
\text { practice }\end{array}$ & $\begin{array}{l}\text { a pilot audit } \\
\text { of regional } \\
\text { prescribing } \\
\text { pattems }\end{array}$ & $\begin{array}{l}\text { descriptive } \\
\text { paper } \\
\text { about a } \\
\text { pilot study }\end{array}$ & $\begin{array}{l}\text { there was a marked varia- } \\
\text { tion between GPs in medi- } \\
\text { cines choice, cost and } \\
\text { number of script }\end{array}$ \\
\hline 26 & 1985 & $\begin{array}{l}\text { to determine the } \\
\text { extent to which } \\
\text { GPs would partic- } \\
\text { ipate in quality } \\
\text { assessment activ- } \\
\text { ities based on } \\
\text { objective evi- } \\
\text { dence of perfor- } \\
\text { mance and the } \\
\text { personal and pro- } \\
\text { fessional charac- } \\
\text { teristics of inter- } \\
\text { ested doctors }\end{array}$ & $\begin{array}{l}\text { UK, } \\
\text { Leicester- } \\
\text { shire and } \\
\text { Lincoln- } \\
\text { shire }\end{array}$ & $\begin{array}{l}508 \text { replies } \\
\text { on } 669 \\
\text { question- } \\
\text { naires }\end{array}$ & $\begin{array}{l}\text { highest response rates } \\
\text { were recorded by trainers, } \\
\text { principals and younger } \\
\text { doctors; lowest by over- } \\
\text { seas graduates and older } \\
\text { doctors; most of the re- } \\
\text { spondents (61\%) were } \\
\text { interested in audit activi- } \\
\text { ties, ranked from high to } \\
\text { low interest: performance } \\
\text { review using all, some or } \\
\text { no information provided by } \\
\text { external agencies; most } \\
\text { enthusjastic and active } \\
\text { groups were trainers, } \\
\text { principals in training or } \\
\text { large group practices and } \\
\text { members or fellows of the } \\
\text { RCGP, young doctors, vo- } \\
\text { cationally trained doctors }\end{array}$ \\
\hline 43 & 1999 & $\begin{array}{l}\text { to describe pre- } \\
\text { scriptive behav- } \\
\text { lour among GPs } \\
\text { in choosing an } \\
\text { empirical antibi- } \\
\text { otic regimen for } \\
\text { LRTIs and to be- } \\
\text { gin an educa- } \\
\text { tional process }\end{array}$ & $\begin{array}{l}76 \text { GPs in } \\
\text { Sicily, sep- } \\
\text { tember } \\
1995 / \text { may } \\
1996\end{array}$ & $\begin{array}{l}\text { question- } \\
\text { naires for } \\
\text { each thera- } \\
\text { peutic in- } \\
\text { tervention } \\
\text { which } \\
\text { ended with } \\
\text { an antibi- } \\
\text { otic }\end{array}$ & $\begin{array}{l}\text { the marked variation re- } \\
\text { flects lack of availability ar } \\
\text { knowledge of any local or } \\
\text { national guidelines; }\end{array}$ \\
\hline 50 & 1996 & $\begin{array}{l}\text { to demonstrate } \\
\text { whether standard- } \\
\text { ization of practice } \\
\text { populations by } \\
\text { age and sex } \\
\text { changes the inter- } \\
\text { nal prescription } \\
\text { ranking order of a } \\
\text { group of practices }\end{array}$ & $\begin{array}{l}41 \text { GPs in } \\
35 \text { prac- } \\
\text { tices in } \\
\text { Randers } \\
\text { Aarhus } \\
\text { county. } \\
\text { Denmark }\end{array}$ & $\begin{array}{l}\text { data on the } \\
\text { prescribing } \\
\text { of cardio- } \\
\text { vascular } \\
\text { drugs in a } \\
\text { group of } \\
\text { practices } \\
\text { were ob- } \\
\text { tained from } \\
\text { a county- } \\
\text { based da- } \\
\text { tabase }\end{array}$ & $\begin{array}{l}\text { the change from crude to } \\
\text { standardized utilization } \\
\text { index gave an entirely new } \\
\text { ranking order of the prac- } \\
\text { tices; the slope between } \\
\text { the highest and lowest } \\
\text { ranked practice did not } \\
\text { diminish after standardiza- } \\
\text { tion; prior age and sex } \\
\text { standardization is recom- } \\
\text { mended when comparing } \\
\text { peer prescribing patterns }\end{array}$ \\
\hline
\end{tabular}




\begin{tabular}{|c|c|c|c|c|c|}
\hline 53 & 1996 & $\begin{array}{l}\text { to compare the } \\
\text { author's prescrib- } \\
\text { ing habits for anti- } \\
\text { biotics in two dif- } \\
\text { ferent work set- } \\
\text { tings and to study } \\
\text { the reasons for } \\
\text { the observed dif- } \\
\text { ferent trends }\end{array}$ & $\begin{array}{l}\text { in Scandi- } \\
\text { navia in a } \\
\text { solo prac- } \\
\text { tice in a } \\
\text { fishing vil- } \\
\text { lage over } \\
1984-87 \\
\text { and a } \\
\text { group prac- } \\
\text { tice in a } \\
\text { town over } \\
1987-92\end{array}$ & $\begin{array}{l}\text { a retro- } \\
\text { spective } \\
\text { database } \\
\text { study of } \\
\text { computer- } \\
\text { based pa- } \\
\text { tient re- } \\
\text { cords }\end{array}$ & $\begin{array}{l}\text { in the solo-practice the GP } \\
\text { reduced the number of } \\
\text { prescriptions for antibiot- } \\
\text { ics significantly from } 82.9 \\
\text { to } 63.8 \text { per } 1000 \text { contacts; } \\
\text { in the group practice the } \\
\text { number increased from } \\
82.6 \text { to } 90.5 \text { (NS); there } \\
\text { was an increase of work- } \\
\text { load during the (latter) } \\
\text { study period(s), with a } \\
\text { looser affiliation to the pa } \\
\text { tient group; GPs should be } \\
\text { able to reduce their num- } \\
\text { ber of prescriptions of anti- } \\
\text { biotics to some extent; if } \\
\text { interested in doing so; a } \\
\text { computer based quality } \\
\text { control is essential for the } \\
\text { purpose, because the ex- } \\
\text { pectations of the patients, } \\
\text { the surrounding of the doc- } \\
\text { tor and his work enwiron- } \\
\text { ment determine to a great } \\
\text { extent his antibiotic pre- } \\
\text { scribing habits }\end{array}$ \\
\hline 67 & 1996 & $\begin{array}{l}\text { to examine the } \\
\text { extent to which } \\
\text { four broad areas } \\
\text { of concern asso- } \\
\text { ciated with pre- } \\
\text { scribing are per- } \\
\text { ceived by GPs: } \\
\text { their sense of bur- } \\
\text { den in providing } \\
\text { health care, their } \\
\text { views on financial } \\
\text { constraints and } \\
\text { incentives, the } \\
\text { use of a prescrip- } \\
\text { tion to cope with } \\
\text { clinical workload } \\
\text { and their percep- } \\
\text { tion of demanding } \\
\text { patients }\end{array}$ & UK & $\begin{array}{l}\text { question- } \\
\text { naire to } \\
386 \text { GPs, } \\
59 \% \text { re- } \\
\text { sponded }\end{array}$ & $\begin{array}{l}\text { results indicated a high } \\
\text { level of concern among } \\
\text { GPs regarding current } \\
\text { pressures that could affect } \\
\text { prescribing; the respon- } \\
\text { dents' concern about pos- } \\
\text { sible adverse effects of } \\
\text { financial pressures upon } \\
\text { medical decisions was re- } \\
\text { lated to prescribing: those } \\
\text { concerned prescribed less } \\
\text { generically, thad higher } \\
\text { practice costs, and issued } \\
\text { more prescriptions; there } \\
\text { is a continuing need to } \\
\text { monitor and evaluate the } \\
\text { effect of recent changes in } \\
\text { primary care for their effect } \\
\text { upon prescribing behav- } \\
\text { lour. }\end{array}$ \\
\hline
\end{tabular}




\begin{tabular}{|c|c|c|c|c|c|}
\hline 100 & 1999 & $\begin{array}{l}\text { diffusion of new } \\
\text { drugs in general } \\
\text { practice }\end{array}$ & $\begin{array}{l}\text { five new } \\
\text { drugs in } \\
\text { North } \\
\text { Jutland } \\
\text { County } \\
(490.000 \\
\text { inhabi- } \\
\text { tants) pre- } \\
\text { scribed by } \\
95 \text { solo } \\
\text { practitio- } \\
\text { ners }\end{array}$ & $\begin{array}{l}\text { prescrip- } \\
\text { tions identi- } \\
\text { fied in pre- } \\
\text { scription } \\
\text { database }\end{array}$ & $\begin{array}{l}\text { late prescribers share } \\
\text { some common character- } \\
\text { istics, such as a tendency } \\
\text { to lower diagnostic activity } \\
\text { per patient }\end{array}$ \\
\hline 108 & 1993 & $\begin{array}{l}\text { to determine the } \\
\text { effect of three } \\
\text { types of interac- } \\
\text { tions between } \\
\text { GPs and pharma- } \\
\text { ceuticall compa- } \\
\text { nies }\end{array}$ & $\begin{array}{l}2227 \text { pa- } \\
\text { pers re- } \\
\text { viewed } \\
\text { within crite- } \\
\text { ria: } 36 \\
\text { studies } \\
\text { matched }\end{array}$ & $\begin{array}{l}\text { literature } \\
\text { search } \\
1978 \text { - } \\
1993\end{array}$ & $\begin{array}{l}\text { many GPs regard PCs as } \\
\text { important sources of fund- } \\
\text { ing clinical trials, the inter- } \\
\text { actions of GPs and PCs } \\
\text { affect GPs prescribing be- } \\
\text { haviour, obtaining informa- } \\
\text { tion from detailers makes } \\
\text { prescribing practices less } \\
\text { appropriate; GPs are af- } \\
\text { fected by their interactions } \\
\text { with PCs }\end{array}$ \\
\hline 179 & 1994 & $\begin{array}{l}\text { relation between } \\
\text { GPs' characteris- } \\
\text { tics and prescrib- } \\
\text { ing for elderly pa- } \\
\text { tients }\end{array}$ & $376 \mathrm{GPs}$ & $\begin{array}{l}\text { linking } 2 \\
\text { provincial } \\
\text { databases }\end{array}$ & $\begin{array}{l}\text { high prescribers had more } \\
\text { practice days, saw more } \\
\text { patients per day, per- } \\
\text { formed more services per } \\
\text { day, billed more per pa- } \\
\text { tient and billed more pre- } \\
\text { scriptions than low pre- } \\
\text { scribers }\end{array}$ \\
\hline
\end{tabular}




\begin{tabular}{|c|c|c|c|c|c|}
\hline \multicolumn{6}{|c|}{ routine behaviour } \\
\hline 4 & 1996 & $\begin{array}{l}\text { to explore GP's' } \\
\text { reasons for recent } \\
\text { changes in their } \\
\text { prescribing be- } \\
\text { haviour }\end{array}$ & $\begin{array}{l}18 \mathrm{GPs} \text { in } \\
\text { general } \\
\text { practices in } \\
\text { south east } \\
\text { London, } \\
\text { UK }\end{array}$ & $\begin{array}{l}\text { qualitative } \\
\text { analysis of } \\
\text { semi-struc- } \\
\text { tured inter- } \\
\text { views over } \\
\text { prescribing } \\
\text { in the pre- } \\
\text { ceding } 6 \\
\text { months }\end{array}$ & $\begin{array}{l}\text { regarding the most fre- } \\
\text { quently mentioned chang- } \\
\text { es related to fluoxetine, } \\
\text { ACE-inhibitors, and antibi- } \\
\text { otic treatment of } \mathrm{H} \text {. pylori, } \\
3 \text { models were identified: } \\
\text { accumulation (following } \\
\text { volume and authority of } \\
\text { evidence) challenge (fol- } \\
\text { lowing a dramatic or con- } \\
\text { flicting clinical event) and } \\
\text { continulity ( willingness to } \\
\text { change cost pressures } \\
\text { and comprehensible drug } \\
\text { action) which have impor- } \\
\text { tant implications for the } \\
\text { design and evaluation of } \\
\text { interventions aimed at } \\
\text { change of behaviour }\end{array}$ \\
\hline 21 & 1995 & $\begin{array}{l}\text { to measure tacit } \\
\text { policies used by } \\
\text { GPs in prescrib- } \\
\text { ing lipid lowering } \\
\text { agents and to } \\
\text { compare these } \\
\text { with their stated } \\
\text { policies }\end{array}$ & $\begin{array}{l}35 \text { GPs in } \\
\text { the Plym- } \\
\text { outh area } \\
\text { ranged } \\
\text { from } 31 \text { to } \\
55 \text { years; } \\
\text { all but four } \\
\text { were men }\end{array}$ & $\begin{array}{l}\text { tacit poli- } \\
\text { cles: rating } \\
130 \text { imagi- } \\
\text { nary cases } \\
\text { presented } \\
\text { by a com- } \\
\text { puter, raw } \\
\text { data were } \\
\text { converted } \\
\text { into statisti- } \\
\text { cal weigh } \\
\text { tings by } \\
\text { use of mul- } \\
\text { tiple linear } \\
\text { regression; } \\
\text { stated poli- } \\
\text { cies: inter- } \\
\text { views }\end{array}$ & $\begin{array}{l}\text { both tacit and stated poll- } \\
\text { cies diverged widely be- } \\
\text { tween different doctors; } \\
\text { doctors' policies are highly } \\
\text { variable and paarticularly } \\
\text { inconsistent in the treat- } \\
\text { ment of smokers, relevant } \\
\text { risik factors may be ig- } \\
\text { nored, even when under- } \\
\text { stood, because risk as- } \\
\text { sessment is too psycho- } \\
\text { logically complex a task to } \\
\text { be performed intuitively: } \\
\text { decision aids and clear } \\
\text { protocols are needed in } \\
\text { this area }\end{array}$ \\
\hline
\end{tabular}




\begin{tabular}{|c|c|c|c|c|c|}
\hline 68 & 1989 & $\begin{array}{l}\text { to describe the } \\
\text { GPs decision- } \\
\text { making process } \\
\text { in selecting drugs }\end{array}$ & $\begin{array}{l}\text { the Nether- } \\
\text { lands }\end{array}$ & $\begin{array}{l}\text { analysis of } \\
\text { the } \\
\text { decision- } \\
\text { making } \\
\text { process } \\
\text { using gen- } \\
\text { eral mod- } \\
\text { els of hu- } \\
\text { man deci- } \\
\text { sion mak- } \\
\text { ing and } \\
\text { consumer } \\
\text { behaviour }\end{array}$ & $\begin{array}{l}\text { in } 90 \% \text { of the cases the } \\
\text { GP depends on ready } \\
\text { memory and chooses be- } \\
\text { tween } 4-5 \text { drugs that come } \\
\text { to mind first: chemical } \\
\text { properties and action rank } \\
\text { highest in the structure of } \\
\text { memory storage, prior to } \\
\text { price, efficacy and Dutch } \\
\text { make; prescription prefer- } \\
\text { ences are primarily deter- } \\
\text { mined by side effects and } \\
\text { efficacy. }\end{array}$ \\
\hline
\end{tabular}




\begin{tabular}{|c|c|c|c|c|c|}
\hline ref. & year & objective & setting & design & results / comments \\
\hline \multicolumn{6}{|c|}{ efficacy } \\
\hline 6 & 1998 & $\begin{array}{l}\text { to revue issues of } \\
\text { legal liabillity in } \\
\text { prescribing } \\
\text { choice }\end{array}$ & $\begin{array}{l}\text { antidepres- } \\
\text { sants in } \\
\text { psychiatry }\end{array}$ & $\begin{array}{l}\text { review } \\
\text { with partic- } \\
\text { ular refier- } \\
\text { ence to } \\
\text { prescribing } \\
\text { antide- } \\
\text { pressants }\end{array}$ & $\begin{array}{l}\text { adverse outcome of a } \\
\text { treatment raises the poten- } \\
\text { tial of profiessional negli- } \\
\text { gence claims to be } \\
\text { brought against medical } \\
\text { practitioners who prescribe } \\
\text { certain medicines for rea- } \\
\text { sons other than estab- } \\
\text { lished medical need }\end{array}$ \\
\hline 7 & 1997 & $\begin{array}{l}\text { to study the effec- } \\
\text { tiveness of antibi- } \\
\text { otic prescribing } \\
\text { patterns for otitis } \\
\text { media and their } \\
\text { associated ex- } \\
\text { penditures or the } \\
\text { factors that influ- } \\
\text { ence antibiotic } \\
\text { prescribing }\end{array}$ & $\begin{array}{l}\text { out of } \\
288.234 \\
\text { children, } \\
12.381 \text { with } \\
\text { a new epi- } \\
\text { sode of } \\
\text { acute otitis } \\
\text { media in } \\
1991 / 2 \text { in } \\
\text { Colorado's } \\
\text { fee-for-ser- } \\
\text { vice } \\
\text { Medicaid } \\
\text { program }\end{array}$ & $\begin{array}{l}\text { analysis of } \\
\text { the entire } \\
\text { Medicaid } \\
\text { population, } \\
\text { prescrip- } \\
\text { tion by } \\
\text { GPs and } \\
\text { hospital } \\
\text { physicians }\end{array}$ & $\begin{array}{l}\text { amoxicillin seems to be } \\
\text { the first choice as the ini- } \\
\text { tial antibiotic for a new epi- } \\
\text { sode of acute otitis media; } \\
\text { there was a wide variation } \\
\text { in the selection of antibiot- } \\
\text { ics to treat otitis and this } \\
\text { has important implications } \\
\text { because of differences in } \\
\text { antibiotics costs; the more } \\
\text { expensive antibiotics were } \\
\text { not associated with better } \\
\text { outcomes; reducing the } \\
\text { use of high-cost antibiotics } \\
\text { could reduce expenditures } \\
\text { without compromising } \\
\text { short-term outcomes }\end{array}$ \\
\hline 13 & 1998 & $\begin{array}{l}\text { to better under- } \\
\text { stand reasons for } \\
\text { antibiotics being } \\
\text { prescribed for } \\
\text { sore throats de- } \\
\text { spite well known } \\
\text { evidence that } \\
\text { they are generally } \\
\text { of little help }\end{array}$ & $\begin{array}{l}21 \text { GPs in } \\
\text { general } \\
\text { practices in } \\
\text { South } \\
\text { Wales and } \\
17 \text { patients }\end{array}$ & $\begin{array}{l}\text { qualitative } \\
\text { study with } \\
\text { semi-struc- } \\
\text { tured } \\
\text { interviews }\end{array}$ & $\begin{array}{l}\text { repeating evidence for lack } \\
\text { of effectiveness is unlikely } \\
\text { to change doctors pre- } \\
\text { scribing, but information } \\
\text { about risk to individual pa- } \\
\text { tients might. }\end{array}$ \\
\hline
\end{tabular}




\begin{tabular}{|c|c|c|c|c|c|}
\hline 16 & 1998 & $\begin{array}{l}\text { insight into the } \\
\text { reasons for actual } \\
\text { prescribing of an- } \\
\text { tibiotics for acute } \\
\text { otitis media }\end{array}$ & $\begin{array}{l}70 \text { antib- } \\
\text { otic pre- } \\
\text { scriptions } \\
\text { by } 22 \\
\text { Dutch GPs } \\
\text { were } \\
\text { evaluated }\end{array}$ & $\begin{array}{l}\text { discussion } \\
\text { in stimu- } \\
\text { lated recall } \\
\text { interviews }\end{array}$ & $\begin{array}{l}77 \% \text { of the prescriptions } \\
\text { did not follow the NHG- } \\
\text { guidelines; appropriate } \\
\text { use of antibiotics might not } \\
\text { be reached by focussing } \\
\text { only on the efficacy of } \\
\text { these drugs }\end{array}$ \\
\hline 27 & 1994 & $\begin{array}{l}\text { to describe the } \\
\text { use of the Euro- } \\
\text { pean Formulary }\end{array}$ & $\begin{array}{l}15 \text { coun- } \\
\text { tries in Eu- } \\
\text { rope }\end{array}$ & $\begin{array}{l}\text { vision and } \\
\text { discussion }\end{array}$ & $\begin{array}{l}\text { in } 1992 \text { in Germany } \\
31,1 \% \text { of the ambulatory } \\
\text { drug prescriptions were for } \\
\text { drugs with questionable } \\
\text { efficacy or dubious combi- } \\
\text { nation preparations }\end{array}$ \\
\hline 41 & 1997 & $\begin{array}{l}\text { to examine inter- } \\
\text { ceptions and dis- } \\
\text { continuations of } \\
\text { antidepressants } \\
\text { in general prac- } \\
\text { tice }\end{array}$ & $\begin{array}{l}\text { a represen- } \\
\text { tative panel } \\
\text { of GPS in } \\
\text { England, } \\
\text { Wales and } \\
\text { Scotland }\end{array}$ & $\begin{array}{l}\text { an obser- } \\
\text { vational } \\
\text { study ana- } \\
\text { liysing a } \\
\text { sample of } \\
\text { recorded } \\
\text { prescribing } \\
\text { activity- } \\
\text { data from } \\
\text { an ongoing } \\
\text { cross sec- } \\
\text { tional } \\
\text { postal sur- } \\
\text { vey }\end{array}$ & $\begin{array}{l}\text { the number of newly pre- } \\
\text { scribed courses of antide- } \\
\text { pressants increased by } \\
116 \% \text { between } 1 \text { july } 1990 \\
\text { and } 30 \text { june } 1995 \text {, mostly } \\
\text { due to an increase in pre- } \\
\text { scribing SSRI's; SSRI's } \\
\text { are less likely than tricyclic } \\
\text { antidepressants to be dis- } \\
\text { continued; there was more } \\
\text { switching away from } \\
\text { SSRI's when they failed, } \\
\text { than from tricyclic antide- } \\
\text { pressants }\end{array}$ \\
\hline 47 & 1992 & $\begin{array}{l}\text { to determine the } \\
\text { paltern of drug } \\
\text { use for all drugs } \\
\text { in the Italian } \mathrm{Na} \text { - } \\
\text { tional Formulary }\end{array}$ & $\begin{array}{l}3866 \text { GPs } \\
\text { Northern } \\
\text { llaly }\end{array}$ & $\begin{array}{l}\text { data analy- } \\
\text { sis of pre- } \\
\text { scriptions } \\
\text { for all } \\
\text { drugs in } \\
1988 / 89\end{array}$ & $\begin{array}{l}\text { there was a slight increase } \\
\text { in total drug prescriptions } \\
\text { and a greater change in } \\
\text { those recently marketed; } \\
\text { in comparison to other } \\
\text { countries there was over } \\
\text { prescription of H2-antago- } \\
\text { nists, ACE-inhibitors, Ca } \\
\text { antagonists and HMG- } \\
\text { CoA-reductase inhibitors; } \\
\text { also frequent prescribing } \\
\text { of drugs lacking documem- } \\
\text { tation of clinical efficacy; } \\
\text { educational intervention is } \\
\text { needed to improve the } \\
\text { quality of prescribing }\end{array}$ \\
\hline
\end{tabular}




\begin{tabular}{|c|c|c|c|c|c|}
\hline 49 & 1998 & $\begin{array}{l}\text { to state that the } \\
\text { efficacy and } \\
\text { safety of the use } \\
\text { of diuretics is } \\
\text { wrongly neglected } \\
\text { by prescribers }\end{array}$ & $\begin{array}{l}\text { US recom- } \\
\text { mendatiom } \\
\text { by the JNC } \\
\text { MI }\end{array}$ & $\begin{array}{l}\text { theoretical } \\
\text { foundation } \\
\text { of the } \\
\text { recommen } \\
\text { dations }\end{array}$ & $\begin{array}{l}\text { despite evidence based } \\
\text { national recommendations } \\
\text { the use of diuretics has } \\
\text { steadily decreased over } \\
\text { the past } 15 \text { years, reasons } \\
\text { include the heawy promo- } \\
\text { tion of other medications } \\
\text { and misunderstandings } \\
\text { about adverse effects and } \\
\text { lack of efficacy }\end{array}$ \\
\hline 55 & 1996 & $\begin{array}{l}\text { to gain insight into } \\
\text { the current use of } \\
\text { EDL-products by } \\
\text { GPS }\end{array}$ & $\begin{array}{l}\text { South Af- } \\
\text { rica }\end{array}$ & $\begin{array}{l}\text { rewiewing } \\
120.000 \\
\text { prescrip- } \\
\text { tions }\end{array}$ & $\begin{array}{l}22,4 \% \text { of current GP pre- } \\
\text { scriptions included EDL } \\
\text { items, } 19,6 \% \text { included } \\
\text { other forms of EDL items; } \\
\text { this gap between EDL and } \\
\text { prescribed drugs indicates, } \\
\text { that debate will be }\end{array}$ \\
\hline 68 & 1989 & $\begin{array}{l}\text { to describe the } \\
\text { GPs decision- } \\
\text { making process } \\
\text { in selecting drugs }\end{array}$ & $\begin{array}{l}\text { the Nether- } \\
\text { lands }\end{array}$ & $\begin{array}{l}\text { anallysis of } \\
\text { the } \\
\text { decision- } \\
\text { making } \\
\text { process } \\
\text { using gen- } \\
\text { erall mod- } \\
\text { els of hu- } \\
\text { man deci- } \\
\text { sion } \\
\text { making } \\
\text { and con- } \\
\text { sumer be- } \\
\text { haviour }\end{array}$ & $\begin{array}{l}\text { in } 90 \% \text { of the cases the } \\
\text { GP depends on ready } \\
\text { memory and chooses from } \\
\text { among proprietary } 4-5 \\
\text { drugs that come to mind } \\
\text { first; chemical properties } \\
\text { and action rank highest in } \\
\text { the structure of memory } \\
\text { storage, prior to price, effi- } \\
\text { cacy and Dutch make; pre- } \\
\text { scription preferences are } \\
\text { primarily determined by } \\
\text { side effects and efficacy. }\end{array}$ \\
\hline 90 & 1999 & $\begin{array}{l}\text { voluntary } \\
\text { changes in } \\
\text { antiemetic pre- } \\
\text { scribing practice }\end{array}$ & $\begin{array}{l}\text { postanesth } \\
\text { esia care } \\
\text { unit in an } \\
\text { academic } \\
\text { medical } \\
\text { centre }\end{array}$ & $\begin{array}{l}\text { prospec- } \\
\text { tive, obser- } \\
\text { vational } \\
\text { study with } \\
\text { random- } \\
\text { lzed com- } \\
\text { ponent }\end{array}$ & $\begin{array}{l}\text { patients satisfaction be- } \\
\text { tween ondansetron } 4 \mathrm{mg} \\
\text { and droperidol } 0,625 \mathrm{mg} \\
\text { did not differ in spite of } \\
\text { slightly greater efficacy of } \\
\text { ondansetron }\end{array}$ \\
\hline
\end{tabular}




\begin{tabular}{|c|c|c|c|c|c|}
\hline 111 & 1894 & $\begin{array}{l}\text { evaluate appro- } \\
\text { priateness of } \\
\text { ciprofloxacine- } \\
\text { prescribing }\end{array}$ & $\begin{array}{l}\text { large aca- } \\
\text { demically } \\
\text { oriented } \\
\text { long-term } \\
\text { care facil- } \\
\text { ity: } 100 \text { ran- } \\
\text { domly se- } \\
\text { lected or- } \\
\text { ders over } 3 \\
\text { years }\end{array}$ & $\begin{array}{l}\text { retrospec- } \\
\text { tive chart } \\
\text { review; in } \\
\text { population } \\
\text { of elderly } \\
\text { patients } \\
\text { (mean age } \\
88 y)\end{array}$ & $\begin{array}{l}\text { taking into account indica- } \\
\text { tion, effectiveness and/or } \\
\text { price, only } 25 \% \text { of the or- } \\
\text { ders were judged appropri- } \\
\text { ate, indicating, that pre- } \\
\text { scribing was less than op- } \\
\text { timal }\end{array}$ \\
\hline 115 & 1997 & $\begin{array}{l}\text { to measure the } \\
\text { relative cost-ef- } \\
\text { fectiveness of } \\
\text { statines in a real- } \\
\text { world setting }\end{array}$ & Texas, US & $\begin{array}{l}\text { prospec- } \\
\text { tive, ran- } \\
\text { domized, } \\
\text { balanced } \\
\text { cohort de- } \\
\text { sign over } 6 \\
\text { months of } \\
\text { initial ther- } \\
\text { apy }\end{array}$ & $\begin{array}{l}\text { well designed formularies } \\
\text { should consider drug CE; } \\
\text { integration of the phar- } \\
\text { macy benefit management } \\
\text { with other medical man- } \\
\text { agement is essential ; } \\
\text { fluvastatin may represent } \\
\text { a more cost effective for- } \\
\text { mulary choice among } \\
\text { statin products used for } \\
\text { initial monotherapy of hy- } \\
\text { percholesterolemia }\end{array}$ \\
\hline \multicolumn{6}{|c|}{ safety of drugs } \\
\hline 6 & 1998 & $\begin{array}{l}\text { to revue issues of } \\
\text { legal liability in } \\
\text { prescribing } \\
\text { choice }\end{array}$ & $\begin{array}{l}\text { antidepres- } \\
\text { sants in } \\
\text { psychiatry }\end{array}$ & $\begin{array}{l}\text { review } \\
\text { with partic- } \\
\text { ular refer- } \\
\text { ence to } \\
\text { prescribing } \\
\text { antide- } \\
\text { pressants }\end{array}$ & $\begin{array}{l}\text { adverse outcome of a } \\
\text { treatment raises the poten- } \\
\text { tial of professional negli- } \\
\text { gence claims to be } \\
\text { brought against medical } \\
\text { practitioners who prescribe } \\
\text { certain medicines for rea- } \\
\text { sons other than estab- } \\
\text { lished medical need }\end{array}$ \\
\hline 88 & 1999 & $\begin{array}{l}\text { to review strate- } \\
\text { gles that may in- } \\
\text { fluence prescrib- } \\
\text { ing behaviour and } \\
\text { to discuss practi- } \\
\text { cal considerations } \\
\text { for achieving opti- } \\
\text { mal prescribing in } \\
\text { view of tolerablilty } \\
\text { concerns }\end{array}$ & $\begin{array}{l}\text { The Neth- } \\
\text { erlands }\end{array}$ & $\begin{array}{l}\text { review } \\
\text { and dis- } \\
\text { cussion }\end{array}$ & $\begin{array}{l}\text { the patient has a major } \\
\text { influence on prescribing; } \\
\text { communication between } \\
\text { health care workers as- } \\
\text { sumes a vital role, mes- } \\
\text { sages regarding patients, } \\
\text { prescribing patterns and } \\
\text { drug tolerability should be } \\
\text { coherent and transferable. }\end{array}$ \\
\hline
\end{tabular}




\begin{tabular}{|c|c|c|c|c|c|}
\hline 103 & 1993 & $\begin{array}{l}\text { to find out why } \\
\text { the response rate } \\
\text { to requests to } \\
\text { GPs to supply } \\
\text { post-marketing } \\
\text { data on new } \\
\text { drugs has been } \\
\text { falling }\end{array}$ & $\begin{array}{l}543788 \\
\text { treatments } \\
\text { with } 27 \\
\text { PEM-drugs; } \\
1984-9 \text { by } \\
28402 \text { Gps } \\
\text { in England }\end{array}$ & $\begin{array}{l}\text { reviewing } \\
\text { dispensing } \\
\text { data }\end{array}$ & $\begin{array}{l}\text { no medical need can ex- } \\
\text { plain the heawy prescribing } \\
\text { of new drugs by } 400-800 \\
\text { GPs, so it seems not pru- } \\
\text { dent to expose so many } \\
\text { people to potential risks }\end{array}$ \\
\hline 105 & 1997 & $\begin{array}{l}\text { assess the } \\
\text { awareness of re- } \\
\text { porting Adverse } \\
\text { Drug Reactions } \\
\text { (ADRs) and iden- } \\
\text { tify reasons for } \\
\text { under reporting }\end{array}$ & $\begin{array}{l}350 \text { GPs } \\
\text { were in- } \\
\text { vited to re- } \\
\text { act, } 207 \\
(59 \%) \text { re- } \\
\text { spondents }\end{array}$ & $\begin{array}{l}\text { question- } \\
\text { naires }\end{array}$ & $\begin{array}{l}\text { unusual or severe ADRs } \\
\text { and/or new drug are im- } \\
\text { portant factors to report: } \\
\text { not reported ADRs were } \\
\text { judged clinical negligible }\end{array}$ \\
\hline 111 & 1994 & $\begin{array}{l}\text { evaluate appro- } \\
\text { priateness of } \\
\text { ciprofloxacine- } \\
\text { prescribing }\end{array}$ & $\begin{array}{l}\text { large aca- } \\
\text { demically } \\
\text { oriented } \\
\text { long-term } \\
\text { care facil- } \\
\text { ity; } 100 \text { ran- } \\
\text { domly se- } \\
\text { lected or- } \\
\text { ders over } 3 \\
\text { years }\end{array}$ & $\begin{array}{l}\text { retrospec- } \\
\text { tive chart } \\
\text { review; in } \\
\text { population } \\
\text { of elderly } \\
\text { patients } \\
\text { (mean age } \\
88 y \text { ) }\end{array}$ & $\begin{array}{l}\text { taking into account: indica- } \\
\text { tion, effectiveness and/or } \\
\text { price, only } 25 \% \text { of the or- } \\
\text { ders were judged appropri- } \\
\text { ate, indicating, that pre- } \\
\text { scribing was less than op- } \\
\text { timal with potential conse- } \\
\text { quences of resistant bac- } \\
\text { terial strains }\end{array}$ \\
\hline
\end{tabular}




\begin{tabular}{|c|c|c|c|c|c|}
\hline \multicolumn{6}{|c|}{ (introduction of new drugs } \\
\hline 8 & 1995 & $\begin{array}{l}\text { to describe utilisa- } \\
\text { tion trends of } 5 \\
\text { new drugs }\end{array}$ & $\begin{array}{l}\text { Australia, } \\
1990-1992\end{array}$ & $\begin{array}{l}\text { descriptive } \\
\text { retrospec- } \\
\text { twe study } \\
\text { with the } \\
\text { use of } \\
\text { DOD/1000 } \\
\text { population } \\
\text { per day }\end{array}$ & $\begin{array}{l}\text { the market uptake has } \\
\text { been modelled using the } \\
\text { sigmaid Emax model for } \\
\text { drug-receptor binding; } \\
\text { good fits were found for all } \\
\text { new drugs in the study: } \\
\text { simvastatin, omeprazole, } \\
\text { budesonide, fluoxetine and } \\
\text { moclobemide, but subst- } \\
\text { antial differences between } \\
\text { drugs occurred in uptake } \\
\text { rate which may be related } \\
\text { to public education cam- } \\
\text { paigns on asthma and cor- } \\
\text { onary heart disease during } \\
\text { the release period }\end{array}$ \\
\hline 41 & 1997 & $\begin{array}{l}\text { to examine inter- } \\
\text { ceptions and dis- } \\
\text { continuations of } \\
\text { antidepressants } \\
\text { in general prac- } \\
\text { tice }\end{array}$ & $\begin{array}{l}\text { a represen- } \\
\text { tative panel } \\
\text { of GPs in } \\
\text { England, } \\
\text { Wales and } \\
\text { Scotland }\end{array}$ & $\begin{array}{l}\text { an obser- } \\
\text { vational } \\
\text { study ana- } \\
\text { lysing a } \\
\text { sample of } \\
\text { recorded } \\
\text { prescribing } \\
\text { activity- } \\
\text { data from } \\
\text { an ongoing } \\
\text { cross sec- } \\
\text { tional } \\
\text { postal sur- } \\
\text { vey }\end{array}$ & $\begin{array}{l}\text { the number of newly pre- } \\
\text { scribed courses of antide- } \\
\text { pressants increased by } \\
116 \% \text { between } 1 \text { jully } 1990 \\
\text { and } 30 \text { june } 1995 \text {, mostly } \\
\text { due to an increase in pre- } \\
\text { scribing SSRI's; SSRl's } \\
\text { are less likely than tricyclic } \\
\text { antidepressants to be dis- } \\
\text { continued; there was more } \\
\text { switching away from } \\
\text { SSRI's when they failed, } \\
\text { than from tricyclic antide- } \\
\text { pressants }\end{array}$ \\
\hline
\end{tabular}




\begin{tabular}{|c|c|c|c|c|c|}
\hline 47 & 1992 & $\begin{array}{l}\text { to determine the } \\
\text { pattern of drug } \\
\text { use for all drugs } \\
\text { in the ltalian } \mathrm{Na} \text { - } \\
\text { tional Formulary }\end{array}$ & $\begin{array}{l}3866 \text { GPs } \\
\text { Northern } \\
\text { ltaly }\end{array}$ & $\begin{array}{l}\text { data analy- } \\
\text { sis of pre- } \\
\text { scriptions } \\
\text { for all } \\
\text { drugs in } \\
1988 / 89\end{array}$ & $\begin{array}{l}\text { there was a slight increase } \\
\text { in total drug prescriptions, } \\
\text { and a greater change in } \\
\text { those recently marketed, } \\
\text { in comparison to other } \\
\text { countries there was over } \\
\text { prescription of } \mathrm{H} 2 \text {-antago- } \\
\text { nists, ACE-inhibitors, Ca } \\
\text { antagonists and HMG- } \\
\text { CoA-reductases inhibitors; } \\
\text { there was frequent pre- } \\
\text { scribing of drugs lacking } \\
\text { documentation of clinical } \\
\text { efficacy; educational inter- } \\
\text { vention is needed to im- } \\
\text { prove the quality of drug } \\
\text { prescribing habits }\end{array}$ \\
\hline 54 & 1997 & $\begin{array}{l}\text { to study whether } \\
\text { the newer antide- } \\
\text { pressants have } \\
\text { changed the pat- } \\
\text { terns of antide- } \\
\text { pressant use, and } \\
\text { whether the } \\
\text { claimed better } \\
\text { adverse effect } \\
\text { profile of lower } \\
\text { antidepressants is } \\
\text { reflected in their } \\
\text { use }\end{array}$ & $\begin{array}{l}\text { the use of } \\
\text { antidepres- } \\
\text { sants from } \\
1991 \text { to } \\
1993 \text { in } \\
\text { Odense, } \\
\text { Denmark }\end{array}$ & $\begin{array}{l}\text { prescrip- } \\
\text { tion data- } \\
\text { base anal- } \\
\text { ysis }\end{array}$ & $\begin{array}{l}\text { the 1-year prevalence in- } \\
\text { creased significantly, but } \\
\text { was still below the claimed } \\
\text { depression prevalence of } \\
5 \% \text {;he increase was } \\
\text { mainly due to rapidly in- } \\
\text { creasing use of newer } \\
\text { antidepressants; a moder- } \\
\text { ate incline of tricyclic } \\
\text { antidepressants was seen; } \\
\text { the share of patients pre- } \\
\text { senting only one prescrip- } \\
\text { tion (20\%) was the same } \\
\text { for ollder and newer antide- } \\
\text { pressants; the duration of } \\
\text { treatment did not differ } \\
\text { much between older and } \\
\text { newer antidepressants; } \\
\text { older antidepressants } \\
\text { were given in much lower } \\
\text { doses (0,63 DDD) then the } \\
\text { newer ones ( } 1,05 \text { DDD) } \\
\text { the claimed better adverse } \\
\text { effect profile of the newer } \\
\text { antidiepressants was not } \\
\text { clearly reflected in their } \\
\text { use }\end{array}$ \\
\hline
\end{tabular}




\begin{tabular}{|c|c|c|c|c|c|}
\hline 98 & 1993 & $\begin{array}{l}\text { to review the pat- } \\
\text { tern of prescribing } \\
\text { medicines in the } \\
\text { UK and compare } \\
\text { it with that in } \\
\text { other European } \\
\text { markets }\end{array}$ & $\begin{array}{l}\text { UK and } \\
\text { Europe }\end{array}$ & rewiew & $\begin{array}{l}\text { British doctors prescribe } \\
\text { fewer iterns, less products } \\
\text { containing a NCE and pro- } \\
\text { gressively from a smaller } \\
\text { number of active sub- } \\
\text { stances for a greater pro- } \\
\text { portion of their prescrip- } \\
\text { tions; as a result the phar- } \\
\text { maceutical industry is } \\
\text { more dependent or the } \\
\text { sales of older products } \\
\text { and the ability to fund their } \\
\text { investment in research into } \\
\text { yet unconquered diseases } \\
\text { is reduced; this trend could } \\
\text { work against the interests } \\
\text { of both patients and the } \\
\text { British economy. }\end{array}$ \\
\hline 100 & 1999 & $\begin{array}{l}\text { diffusion of new } \\
\text { drugs in general } \\
\text { practice }\end{array}$ & $\begin{array}{l}\text { five new } \\
\text { drugs in } \\
\text { North Jut- } \\
\text { land Coun- } \\
\text { ty ( } 490,000 \\
\text { inh.) pre- } \\
\text { scribed by } \\
95 \text { solo } \\
\text { GPs }\end{array}$ & $\begin{array}{l}\text { prescrip- } \\
\text { tions iden- } \\
\text { tified in } \\
\text { prescrip- } \\
\text { tion data- } \\
\text { base }\end{array}$ & $\begin{array}{l}\text { the slope and shape of the } \\
\text { diffusion curve are both } \\
\text { dependant on physician } \\
\text { and drug characteristics }\end{array}$ \\
\hline 101 & 1995 & $\begin{array}{l}\text { discussion about } \\
\text { brand-name } \\
\text { drugs vs generic } \\
\text { products }\end{array}$ & Canada & discussion & $\begin{array}{l}\text { drug formularies limiting } \\
\text { the number of new drugs, } \\
\text { are a major hurdle for } \\
\text { brand-name drug compa- } \\
\text { nies }\end{array}$ \\
\hline 102 & 1993 & $\begin{array}{l}\text { to determine the } \\
\text { use of new drugs } \\
\text { (ACE-inhibitors, } \\
\text { broad spectrum } \\
\text { antibiotics and H2 } \\
\text { receptor antago- } \\
\text { nists) in 1988-91 }\end{array}$ & $\begin{array}{l}\text { all general } \\
\text { practices in } \\
\text { Northern } \\
\text { Ireland }\end{array}$ & $\begin{array}{l}\text { examina- } \\
\text { tion of data } \\
\text { on pre- } \\
\text { scribing } \\
\text { and calcu- } \\
\text { lation of } \\
\text { DDD per } \\
\text { month }\end{array}$ & $\begin{array}{l}\text { prescribing of these new } \\
\text { drugs seems to be greater } \\
\text { than can be accounted for } \\
\text { by an increase in patients } \\
\text { with specific indications for } \\
\text { these drugs }\end{array}$ \\
\hline
\end{tabular}




\begin{tabular}{|c|c|c|c|c|c|}
\hline 104 & 1993 & $\begin{array}{l}\text { describe temporal } \\
\text { trends in prescrip- } \\
\text { tion drug use and } \\
\text { the determinants } \\
\text { of those trends }\end{array}$ & $\begin{array}{l}\text { British Co- } \\
\text { lumbia; } \\
1981-82 \text { vs } \\
1988-89\end{array}$ & $\begin{array}{l}\text { dala from } \\
\text { prescrip- } \\
\text { tion drug } \\
\text { program } \\
\text { for the el- } \\
\text { derly }\end{array}$ & $\begin{array}{l}\text { drug expenditures under } \\
\text { the program increased by } \\
317 \% \text { to } \$ 90 \text { million in } \\
1988-89,34 \% \text { of the in- } \\
\text { crease due to new drugs: } \\
61.5 \% \text { of new drug expen- } \\
\text { ditures attributed to } 4 \text { spe- } \\
\text { cific drugs. }\end{array}$ \\
\hline 105 & 1997 & $\begin{array}{l}\text { assess the } \\
\text { awareness of re- } \\
\text { porting Adverse } \\
\text { Drug Reactions } \\
\text { (ADRs) and iden- } \\
\text { tify reasons for } \\
\text { under reporting }\end{array}$ & $\begin{array}{l}350 \text { GPs } \\
\text { were in- } \\
\text { vited to re- } \\
\text { act, } 207 \\
(59 \%) \text { re- } \\
\text { spondents }\end{array}$ & $\begin{array}{l}\text { question- } \\
\text { naires } \\
\text { about }\end{array}$ & $\begin{array}{l}\text { unusual or severe ADRs } \\
\text { and/or new drug are im- } \\
\text { portant factors to report }\end{array}$ \\
\hline \multicolumn{6}{|c|}{ listing / delisting / reimbursement of drugs } \\
\hline 8 & 1995 & $\begin{array}{l}\text { to describe utilisa- } \\
\text { tion trends of } 5 \\
\text { new drugs }\end{array}$ & $\begin{array}{l}\text { Australia, } \\
1990-1992\end{array}$ & $\begin{array}{l}\text { descriptive } \\
\text { retrospec- } \\
\text { tive study } \\
\text { with the } \\
\text { use of } \\
\text { DDD/1000 } \\
\text { population } \\
\text { per day }\end{array}$ & $\begin{array}{l}\text { the market uptake has } \\
\text { been modelled using the } \\
\text { sigmoid Emax model for } \\
\text { drug-receptor binding; } \\
\text { good fits were found for all } \\
\text { new drugs in the study: } \\
\text { simvastatin, omeprazole, } \\
\text { budesonide, fluoxetine and } \\
\text { moclobemide, but } \\
\text { substantial differences } \\
\text { between drugs occurred in } \\
\text { uptake rate which may be } \\
\text { related to public education } \\
\text { campaigns on asthma and } \\
\text { coronary heart disease } \\
\text { during the release period; }\end{array}$ \\
\hline 28 & 1996 & $\begin{array}{l}\text { to assess how } \\
\text { attitudes and pre- } \\
\text { scribing strategies } \\
\text { of GPs changed } \\
\text { when drugs were } \\
\text { delisted from the } \\
\text { formulary }\end{array}$ & $\begin{array}{l}\text { GPsin On- } \\
\text { tario: } \\
\text { Canada }\end{array}$ & $\begin{array}{l}\text { GPs } \\
\text { opnion } \\
\text { indicated } \\
\text { on a 5- } \\
\text { point } \\
\text { scale, } \\
\text { mailed } \\
\text { self-admin- } \\
\text { istered } \\
\text { survey }\end{array}$ & $\begin{array}{l}\text { GPs usually substituted } \\
\text { listed drugs for medica- } \\
\text { tions delisted, especially } \\
\text { for female patients and } \\
\text { patients who are unable to } \\
\text { pay; GPs believed that } \\
\text { delisting had no adverse } \\
\text { effect on patients, but that } \\
\text { noncompliance could be a } \\
\text { problem, since many } \\
\text { once-daily formulations } \\
\text { had been delisted. }\end{array}$ \\
\hline
\end{tabular}




\begin{tabular}{|c|c|c|c|c|c|}
\hline 99 & 1996 & $\begin{array}{l}\text { to investigate in a } \\
\text { natural experi- } \\
\text { ment the recipient } \\
\text { responses to a } \\
\text { decrease in an } \\
\text { existing prescrip- } \\
\text { tion limit }\end{array}$ & $\begin{array}{l}\text { Georgia } \\
\text { Department } \\
\text { of Medical } \\
\text { Assistance, } \\
\text { US }\end{array}$ & $\begin{array}{l}\text { quasi-ex- } \\
\text { perimental, } \\
\text { retrospec- } \\
\text { tive, } 12- \\
\text { month in- } \\
\text { terrupted } \\
\text { time-series } \\
\text { analysis of } \\
\text { a cohort of } \\
7.43 \text { ambu- } \\
\text { latory high } \\
\text { prescrip- } \\
\text { tion users }\end{array}$ & $\begin{array}{l}\text { prescriptions in } 8 \text { thera- } \\
\text { peutic categories were } \\
\text { analysed before and after } \\
\text { reducing the maximum } \\
\text { number of monthly reim- } \\
\text { bursable prescriptions } \\
\text { from } 6 \text { to } 5 \text { : total prescrip- } \\
\text { tion use fell } 6,6 \% \text {; pre- } \\
\text { scriptions reimbursed by } \\
\text { Medicaid fell } 9,9 \% \text {; pre- } \\
\text { scriptions paid for out-of- } \\
\text { pocket increased } 9,7 \% \text {; } \\
\text { abrupt permanent de- } \\
\text { creases for: cardiovascu- } \\
\text { lar, miscellaneous, pulmo- } \\
\text { nary and palliative drug } \\
\text { categories; remaining con- } \\
\text { stant: } G I \text {, chemotherapy, } \\
\text { hormone (insulin) and } \\
\text { CNS prescriptions; restric- } \\
\text { tive prescription limit alters } \\
\text { prescription regimens po- } \\
\text { tentially predisposing el- } \\
\text { derly Medicaid recipients } \\
\text { to clinical consequences }\end{array}$ \\
\hline 160 & 1995 & $\begin{array}{l}\text { to describe the } \\
\text { change in pre- } \\
\text { scribing patterns } \\
\text { under a major } \\
\text { change in reim- } \\
\text { bursement }\end{array}$ & $\begin{array}{l}\text { the city of } \\
\text { Turin "Italy, } \\
\text { before and } \\
\text { after } 1994\end{array}$ & $\begin{array}{l}\text { a natural } \\
\text { experiment } \\
\text { and a da- } \\
\text { tabase in- } \\
\text { cluding the } \\
\text { prescr. of } \\
940 \mathrm{GPs} \\
\text { dispensed } \\
\text { through } \\
280 \text { comm. } \\
\text { pharmac. }\end{array}$ & $\begin{array}{l}\text { classification of drugs on } \\
\text { account of clinical effec- } \\
\text { tiveness or (un) favourable } \\
\text { cost/benefit ratio made } \\
\text { drugs that were among the } \\
\text { most prescribe: not reim- } \\
\text { bursable; remarkable } \\
\text { changes were provoked }\end{array}$ \\
\hline
\end{tabular}




\begin{tabular}{|c|c|c|c|c|c|}
\hline \multicolumn{6}{|c|}{ costs } \\
\hline 5 & 1996 & $\begin{array}{l}\text { to examine the } \\
\text { effects of a finan- } \\
\text { cial incentive } \\
\text { scheme on pre- } \\
\text { scribing in non- } \\
\text { fundholding gen- } \\
\text { eral practices }\end{array}$ & $\begin{array}{l}459 \text { non- } \\
\text { fundholding } \\
\text { practices in } \\
\text { former } \\
\text { Northern } \\
\text { region, UK. } \\
\text { in } 1993-4\end{array}$ & $\begin{array}{l}\text { observa- } \\
\text { tional } \\
\text { study with } \\
\text { an inter- } \\
\text { vention: } \\
\text { target sav- } \\
\text { ings for } \\
\text { practices, } \\
\text { those that } \\
\text { achieved } \\
\text { were paid } \\
\text { part of the } \\
\text { savings }\end{array}$ & $\begin{array}{l}\text { the prescribing behaviour } \\
\text { of non-fundholding GPS } \\
\text { responded to financial in- } \\
\text { centives in a similar way to } \\
\text { that of fundholding GPS; } \\
\text { the incentive scheme did } \\
\text { not seem to reduce the } \\
\text { quality of prescribing }\end{array}$ \\
\hline 7 & 1997 & $\begin{array}{l}\text { to study the effec- } \\
\text { tiveness of antibi- } \\
\text { otic prescribing } \\
\text { patterns for otitis } \\
\text { media and their } \\
\text { associated ex- } \\
\text { penditures or the } \\
\text { factors that influ- } \\
\text { ence antibiotic } \\
\text { prescribing }\end{array}$ & $\begin{array}{l}\text { out of } \\
288.234 \\
\text { children, } \\
12.381 \text { with } \\
\text { a new epi- } \\
\text { sode of } \\
\text { acute otitis } \\
\text { media in } \\
1991 / 2 \text { in } \\
\text { Colorado's } \\
\text { fee-for-ser- } \\
\text { vice } \\
\text { Medicaid } \\
\text { program }\end{array}$ & $\begin{array}{l}\text { analysis af } \\
\text { the entire } \\
\text { Medicaid } \\
\text { population, } \\
\text { prescrip- } \\
\text { tion by } \\
\text { GPs and } \\
\text { hospital } \\
\text { physicians }\end{array}$ & $\begin{array}{l}\text { amoxicillin seems to be } \\
\text { the first choice as the ini- } \\
\text { tial antibiotic for a new epi- } \\
\text { sode of acute otitis media; } \\
\text { there was a wide variation } \\
\text { in the selection of antibiot- } \\
\text { lcs to treat otitis and this } \\
\text { has important implications } \\
\text { because of differences in } \\
\text { antibiotics costs; the more } \\
\text { expensive antibiotics were } \\
\text { not associated with better } \\
\text { outcomes; reducing the } \\
\text { use of high-cost antibiotics } \\
\text { could reduce expenditures } \\
\text { without compromising } \\
\text { short-term outcomes }\end{array}$ \\
\hline 12 & 1995 & $\begin{array}{l}\text { to test wether an } \\
\text { audit facilitator } \\
\text { could alter the } \\
\text { pattern of diagno- } \\
\text { sis and treatment } \\
\text { of childhood } \\
\text { asthma }\end{array}$ & $\begin{array}{l}12 \text { general } \\
\text { practices in } \\
\text { Tayside. } \\
\text { UK }\end{array}$ & $\begin{array}{l}\text { random- } \\
\text { ised strati- } \\
\text { fied con- } \\
\text { trolled trial }\end{array}$ & $\begin{array}{l}\text { primary care costs rose in } \\
\text { the intervention-group and } \\
\text { fell in the control-group, } \\
\text { hospital inpatient costs fell } \\
\text { in the intervention-group } \\
\text { and rose in the control- } \\
\text { group; result: total costs } \\
\text { rose in both groups, most } \\
\text { in the control-group; an } \\
\text { audit facilitator can favour- } \\
\text { ably infiuence diagnosis } \\
\text { and treatment of childhood } \\
\text { asthma in general prac- } \\
\text { tice, this may have impact } \\
\text { on health service costs }\end{array}$ \\
\hline
\end{tabular}




\begin{tabular}{|c|c|c|c|c|c|}
\hline 19 & 1995 & $\begin{array}{l}\text { to observe } 1 \mathrm{GPS} \\
\text { practice attempt } \\
\text { to reduce pre- } \\
\text { scribing costs } \\
\text { through the intro- } \\
\text { duction af a ge- } \\
\text { neric formulary } \\
\text { and to assess the } \\
\text { impact on pa- } \\
\text { tients and pre- } \\
\text { scribing patterns }\end{array}$ & $\begin{array}{l}1 \text { urban } \\
\text { practice } \\
\text { with } 5 \text { part- } \\
\text { ners in } \\
\text { Scotland, } \\
1993\end{array}$ & $\begin{array}{l}\text { observa- } \\
\text { tional stu- } \\
\text { dy using } \\
\text { interviews } \\
\text { with pa- } \\
\text { tients and } \\
\text { GPs and } \\
\text { through } \\
\text { repeat pre- } \\
\text { scriptions } \\
\text { to identifi- } \\
\text { cation of } \\
\text { changes in } \\
\text { prescrip- } \\
\text { tion }\end{array}$ & $\begin{array}{l}\text { large reduction in prescrib- } \\
\text { ing costs rapidly achieved } \\
\text { (onset within } 4 \text { months) } \\
\text { caused by generic substi- } \\
\text { tution and a reduction of } \\
\text { treatment volume; the } \\
\text { changes were tolerated by } \\
\text { patients, none of them is } \\
\text { thought to have left the } \\
\text { practice for this reason; } \\
\text { great care must be taken } \\
\text { to inform patients appropri- } \\
\text { ately; }\end{array}$ \\
\hline 22 & 1993 & $\begin{array}{l}\text { differentiation be- } \\
\text { tween prescrip- } \\
\text { tions of GPs origi- } \\
\text { nally initiated by } \\
\text { hospital doctors } \\
\text { and prescriptions } \\
\text { originally initiated } \\
\text { by the GPs them- } \\
\text { selves }\end{array}$ & $\begin{array}{l}27 \text { GPs } \\
\text { and } 1,471 \\
\text { prescribed } \\
\text { items }\end{array}$ & $\begin{array}{l}\text { GPs indi- } \\
\text { cate items } \\
\text { on } 30 \text { pre- } \\
\text { scriptions } \\
\text { which they } \\
\text { originally } \\
\text { prescribed } \\
\text { and } \\
\text { whether } \\
\text { they } \\
\text { agreed } \\
\text { with the } \\
\text { items pre- } \\
\text { scribed by } \\
\text { hospital } \\
\text { doctors }\end{array}$ & $\begin{array}{l}54 \% \text { of the costs ( } 65 \% \text { of } \\
\text { the items) initiated by GPS, } \\
44,5 \% \text { of the costs ( } 35 \% \\
\text { of the iterns) initiated by } \\
\text { hospital doctors }\end{array}$ \\
\hline 24 & 1990 & $\begin{array}{l}\text { to develop a } \\
\text { model for cost } \\
\text { effective prescrib- } \\
\text { ing in general } \\
\text { practice }\end{array}$ & $\begin{array}{l}\text { a pilot audit } \\
\text { of regional } \\
\text { prescribing } \\
\text { patterns }\end{array}$ & $\begin{array}{l}\text { descriptive } \\
\text { paper } \\
\text { about a } \\
\text { pilot study }\end{array}$ & $\begin{array}{l}\text { a marked variation be- } \\
\text { tween GPS' dru choice, } \\
\text { cost and number of } \\
\text { prescr; audited prescr. } \\
\text { data allows definitions of } \\
\text { educational and pricing } \\
\text { strategies }\end{array}$ \\
\hline
\end{tabular}




\begin{tabular}{|c|c|c|c|c|c|}
\hline 32 & 1996 & $\begin{array}{l}\text { to audit the influ- } \\
\text { ence of a district } \\
\text { primary care drug } \\
\text { formulary on pre- } \\
\text { scribing by GPs }\end{array}$ & $\begin{array}{l}\text { Bedford- } \\
\text { shire, UK }\end{array}$ & $\begin{array}{l}50 \text { GPs } \\
\text { from } 11 \\
\text { practices } \\
\text { compared } \\
\text { with all } \\
\text { other GPs } \\
\text { in the } \\
\text { county }\end{array}$ & $\begin{array}{l}\text { the proportion of prescrip- } \\
\text { tion items for listed drugs } \\
\text { rose significantly in } 3 \\
\text { groups: cardiovascular, } \\
\text { musculoskeletal and ob- } \\
\text { stetrics/gynaecol; number } \\
\text { of items prescribed per } \\
\text { prescribing fell significantly } \\
\text { in } 3 \text { groups: muscullo-skel- } \\
\text { etal, nervous and nutrition } \\
\text { and blood; estimated sav- } \\
\text { ing f3ooo per GP; cost } \\
\text { reduction sustained } 3 \text { yrs. }\end{array}$ \\
\hline 33 & 1996 & $\begin{array}{l}\text { to determine } \\
\text { wether the extent } \\
\text { of drug change in } \\
\text { hospital and infor- } \\
\text { mation provided } \\
\text { determines the } \\
\text { GPs assessment } \\
\text { of hospital co-op- } \\
\text { eration }\end{array}$ & 554 GPs & $\begin{array}{l}\text { structured } \\
\text { question- } \\
\text { naire sent } \\
\text { to a repre- } \\
\text { sentative } \\
\text { sample of } \\
\text { eastern } \\
\text { and west- } \\
\text { ern Ger- } \\
\text { man doc- } \\
\text { tors }\end{array}$ & $\begin{array}{l}\text { about } 50 \% \text { of the GPS be- } \\
\text { lieved that medication of } \\
\text { more than } 60 \% \text { of their } \\
\text { patients was changled in } \\
\text { hospital in an area with } \\
\text { traditionally separated pri- } \\
\text { mary and secondary care; } \\
\text { hospital-initiated drug } \\
\text { change is a matter of con- } \\
\text { cern }\end{array}$ \\
\hline 34 & 1999 & $\begin{array}{l}\text { to assess the ef- } \\
\text { fectiveness of a } \\
\text { mailled interven- } \\
\text { tion combining } \\
\text { confidential pre- } \\
\text { scribing feedback } \\
\text { with targleted edu- } \\
\text { cational bulletins } \\
\text { in increasing the } \\
\text { use of less ex- } \\
\text { pensive, fist-line } \\
\text { antibiotics by GPs }\end{array}$ & $\begin{array}{l}251 \mathrm{GPs} \\
\text { from South- } \\
\text { ern } \\
\text { Ontario: } \\
135 \text { inter- } \\
\text { vention and } \\
116 \text { in con- } \\
\text { trol group }\end{array}$ & & $\begin{array}{l}\text { prescribing data were col- } \\
\text { lected from the claims da- } \\
\text { tabase; feedback took } \\
\text { place every } 2 \text { - } 6 \text { months; } \\
\text { costs rose in the control } \\
\text { group and remained con- } \\
\text { stant in the feedback- } \\
\text { group; frrst-line drug use } \\
\text { increased in the feedback } \\
\text { group but decreased in the } \\
\text { feedback group; } 82 \% \text { of the } \\
\text { GPs in the feed back } \\
\text { group would readily partici- } \\
\text { pate in another, similar } \\
\text { program }\end{array}$ \\
\hline
\end{tabular}




\begin{tabular}{|c|c|c|c|c|c|}
\hline 42 & 1998 & $\begin{array}{l}\text { to use the DDD } \\
\text { method to study } \\
\text { variation in the } \\
\text { volume and cost } \\
\text { of drugs with a } \\
\text { view to compar- } \\
\text { ing different } \\
\text { methods of set- } \\
\text { ting prescribing } \\
\text { budgets }\end{array}$ & $\begin{array}{l}\text { in } 1995 \text { : } \\
129 \text { gen- } \\
\text { eral prac- } \\
\text { tices in } \\
\text { Lothian. } \\
\text { covering } \\
808.059 \\
\text { patients }\end{array}$ & $\begin{array}{l}\text { study of } \\
\text { one year } \\
\text { of pre- } \\
\text { scribing } \\
\text { statistics }\end{array}$ & $\begin{array}{l}\text { the volume of drugs pre- } \\
\text { scribed for "gastrointesti- } \\
\text { nal", cardiovascular" and } \\
\text { "endocrine" was affected } \\
\text { by the age structure of the } \\
\text { practices; "respiratory" and } \\
\text { "CNS" by deprivation } \\
\text { structure; costs of DDD } \\
\text { were largely independent } \\
\text { of age, deprivation struc- } \\
\text { ture or fundholding status; } \\
\text { DDDbased prescribing } \\
\text { budgets differed substan- } \\
\text { tially from historic budgets; } \\
\text { setting budgets and re- } \\
\text { searching prescribing vari- } \\
\text { ations should be based on } \\
\text { DDD statistics. }\end{array}$ \\
\hline 48 & 1993 & $\begin{array}{l}\text { to derive al predic- } \\
\text { tive modell for na- } \\
\text { tional prescribing } \\
\text { behaviour in } \\
\text { terms of basic } \\
\text { morbidity and de- } \\
\text { mographic fac- } \\
\text { tors. }\end{array}$ & $\begin{array}{l}90 \text { family } \\
\text { health ser- } \\
\text { vice author- } \\
\text { ities in Eng- } \\
\text { land for } \\
1989 .\end{array}$ & $\begin{array}{l}24 \text { demo- } \\
\text { graphic, } \\
\text { morbidity } \\
\text { and prac- } \\
\text { tice factors } \\
\text { into a mul- } \\
\text { tiple re- } \\
\text { gression } \\
\text { analysis to } \\
\text { determine } \\
\text { the net } \\
\text { ingredient } \\
\text { cost per } \\
\text { patient }\end{array}$ & $\begin{array}{l}2 \text { demographic factors ( } \\
\text { numbers of pensioners } \\
\text { and mobility of the regis- } \\
\text { tered population) and } 2 \\
\text { (morbidity factors: stand- } \\
\text { ardised mortality ratios } \\
\text { and numbers of prepay- } \\
\text { ment certificates) signifi- } \\
\text { cantly contributed; } 81 \% \text { of } \\
\text { the variation in net ingredi- } \\
\text { ent cost per registered pa- } \\
\text { tient was explained; } \\
\text { weighting factor for elderly } \\
\text { patients was } 4.6 \text { ( } 3.2-6.7 \text {. } \\
95 \% \text { ); variations essen- } \\
\text { tially reflect demand. }\end{array}$ \\
\hline 52 & 1996 & $\begin{array}{l}\text { to identify trends } \\
\text { in the prescribing } \\
\text { of } \\
\text { antihypertensive } \\
\text { medications and } \\
\text { measure the } \\
\text { changes in gov- } \\
\text { ernment and pa- } \\
\text { tient expenditure } \\
\text { resulting from any } \\
\text { identified change }\end{array}$ & $\begin{array}{l}6 \text { practices } \\
\text { in Otago, } \\
\text { New Zea- } \\
\text { land }\end{array}$ & $\begin{array}{l}\text { retrospec- } \\
\text { tive exami- } \\
\text { nation of } \\
914 \text { out of } \\
16,069 \\
\text { patient re- } \\
\text { ords with } \\
\text { anti-hyper- } \\
\text { tensive } \\
\text { medication } \\
\text { over three } \\
\text { years }\end{array}$ & $\begin{array}{l}63,3 \% \text { remained on the } \\
\text { same class of medication; } \\
36,7 \% \text { changed class; a } \\
\text { clinical reason was identi- } \\
\text { fied for medication change } \\
\text { in } 98 \% \text { of cases, although } \\
\text { better health outcomes for } \\
\text { patients cannot be as- } \\
\text { sumed due to lack of ob- } \\
\text { jective indicators; } \\
\text { changing of class in- } \\
\text { creased costs by } 20.6 \%\end{array}$ \\
\hline
\end{tabular}




\begin{tabular}{|c|c|c|c|c|c|}
\hline 55 & 1996 & $\begin{array}{l}\text { to gain insight into } \\
\text { the current use of } \\
\text { EDL-products by } \\
\text { GPS }\end{array}$ & $\begin{array}{l}\text { South Af- } \\
\text { rica }\end{array}$ & $\begin{array}{l}\text { reviewing } \\
120.000 \\
\text { prescrip- } \\
\text { tions }\end{array}$ & $\begin{array}{l}22,4 \% \text { of current GP pre- } \\
\text { scriptions included EDL } \\
\text { ttems, } 19,6 \% \text { included } \\
\text { other forms of EDL items; } \\
70 \% \text { savings on private } \\
\text { sector GP prescriptions } \\
\text { could be possible by ex- } \\
\text { tending the use of EDL } \\
\text { products; this gap between } \\
\text { EDL and prescribed drugs } \\
\text { must be discussed }\end{array}$ \\
\hline 66 & 1994 & $\begin{array}{l}\text { to examine atti- } \\
\text { tudes toward and } \\
\text { knowledge of } \\
\text { GPs on drug } \\
\text { costs }\end{array}$ & $\begin{array}{l}\text { Ohio State, } \\
\text { US }\end{array}$ & $\begin{array}{l}\text { question- } \\
\text { naire to } \\
137 \text { doc- } \\
\text { tors }\end{array}$ & $\begin{array}{l}\text { primary care physicians } \\
\text { consider costs important, } \\
\text { however the knowledge is } \\
\text { inadequate and costs are } \\
\text { not readily accessible }\end{array}$ \\
\hline 67 & 1996 & $\begin{array}{l}\text { to examine the } \\
\text { extent to which } \\
\text { four broad areas } \\
\text { of concern asso- } \\
\text { ciated with pre- } \\
\text { scribing are per- } \\
\text { ceived by GPs: } \\
\text { their sense of bur- } \\
\text { den in providing } \\
\text { health care, their } \\
\text { views on financial } \\
\text { constraints and } \\
\text { incentives, the } \\
\text { use of a prescrip- } \\
\text { tion to cope with } \\
\text { clinical workload } \\
\text { and their percep- } \\
\text { tion of demanding } \\
\text { patients }\end{array}$ & UK & $\begin{array}{l}\text { question- } \\
\text { naire to } \\
386 \mathrm{GPS}_{1} \\
59 \% \\
\text { responded }\end{array}$ & $\begin{array}{l}\text { results indicated a high } \\
\text { level of concern among } \\
\text { GPs regarding current } \\
\text { pressures that could affect } \\
\text { prescribing; the respon- } \\
\text { dents' concern about pos- } \\
\text { sible adverse effects of } \\
\text { financial pressures upon } \\
\text { medical decisions was } \\
\text { related to prescribing: } \\
\text { thase concerned pre- } \\
\text { scribed less generically } \\
\text { had higher practice costs, } \\
\text { and issued more prescrip- } \\
\text { tions; there is a continuing } \\
\text { need to monitor and evalu- } \\
\text { ate the effect of recent } \\
\text { changes in primary care } \\
\text { for their effect upon pre- } \\
\text { scribing behaviour. }\end{array}$ \\
\hline
\end{tabular}




\begin{tabular}{|c|c|c|c|c|c|}
\hline 69 & 1996 & $\begin{array}{l}\text { to investigate the } \\
\text { variation in pre- } \\
\text { scribing among } \\
\text { GPs by examin- } \\
\text { ing the contribu- } \\
\text { tion to this varia- } \\
\text { tion of fund-hold- } \\
\text { ing, training sta- } \\
\text { tus, partnership } \\
\text { status, and the } \\
\text { level of depriva- } \\
\text { tion in the prac- } \\
\text { tice population } \\
\text { and to investigate } \\
\text { the extent of } \\
\text { fundholding on } \\
\text { any changes in } \\
\text { prescribing }\end{array}$ & $\begin{array}{l}\text { UK, } 384 \\
\text { practices } \\
\text { former Mer- } \\
\text { sey region }\end{array}$ & $\begin{array}{l}\text { analysis of } \\
\text { prescribing } \\
\text { data } \\
\text { (PACT) for } \\
\text { the years } \\
1990- \\
1 \text { (before } \\
\text { fundhold- } \\
\text { ing) and } \\
\text { 1993-4 } \\
\text { (after fund- } \\
\text { holding) }\end{array}$ & $\begin{array}{l}\text { in neither year did } \\
\text { fundholding make a major } \\
\text { contribution to the varia- } \\
\text { tion in prescribing behav- } \\
\text { iour between practices, } \\
\text { which was better ex- } \\
\text { plained by deprivation, } \\
\text { training status and partner- } \\
\text { ship status, but it did seem } \\
\text { largely responsible for dif- } \\
\text { ferences in the rise of total } \\
\text { prescribing costs between } \\
\text { fundholders and non- } \\
\text { fundholders. }\end{array}$ \\
\hline 71 & 1992 & $\begin{array}{l}\text { to study the effect } \\
\text { of the introduction } \\
\text { without continued } \\
\text { reinforcement of } \\
\text { a voluntary prac- } \\
\text { tice formulary on } \\
\text { antimicrobial pre- } \\
\text { scribing in a } \\
\text { group practice }\end{array}$ & UK & $\begin{array}{l}\text { detailed } \\
\text { prescribing } \\
\text { feedback } \\
\text { for two } \\
\text { matched } \\
\text { periods } \\
\text { compared } \\
\text { before and } \\
\text { after } \\
\text { launch of e } \\
\text { formulary }\end{array}$ & $\begin{array}{l}\text { parameters: adherence to } \\
\text { the formulary, generic pre- } \\
\text { scribing and costs; the } \\
\text { high level of formulary pre- } \\
\text { scribing prevalent during } \\
\text { the production of the for- } \\
\text { mulary was not maintained } \\
\text { following its launch, proba- } \\
\text { bly because of the lack of } \\
\text { reinforcement; prescribing } \\
\text { costs increased by } 32 \%\end{array}$ \\
\hline 86 & 1996 & $\begin{array}{l}\text { to evaluate the } \\
\text { influence of GPs' } \\
\text { attitudes toward } \\
\text { and use of infor- } \\
\text { mation provided } \\
\text { by MRs on pre- } \\
\text { scribing costs in } \\
\text { ambulatory prac- } \\
\text { tice }\end{array}$ & $\begin{array}{l}\text { Kentucky } \\
\text { physicians } \\
\text { practising } \\
\text { primary } \\
\text { care adult } \\
\text { medicine (n } \\
=1603 \text { ) }\end{array}$ & $\begin{array}{l}\text { question- } \\
\text { naires }\end{array}$ & $\begin{array}{l}\text { frequency of use of infor- } \\
\text { mation provided by MRs } \\
\text { and group practice setting } \\
\text { were significant, independ- } \\
\text { ent positive predictors of } \\
\text { cost in the multi variable } \\
\text { regression model; } \\
\text { nonacademic and } \\
\text { nonhospital setting may be } \\
\text { associated with increased } \\
\text { primary care physicians } \\
\text { prescribing costs }\end{array}$ \\
\hline
\end{tabular}




\begin{tabular}{|c|c|c|c|c|c|}
\hline 90 & 1999 & $\begin{array}{l}\text { voluntary } \\
\text { changes in } \\
\text { antiemetic pre- } \\
\text { scribing practice }\end{array}$ & $\begin{array}{l}\text { postanes- } \\
\text { thesia care } \\
\text { unit in an } \\
\text { academic } \\
\text { medical } \\
\text { centre }\end{array}$ & $\begin{array}{l}\text { prospec- } \\
\text { tive, obser- } \\
\text { vational } \\
\text { study with } \\
\text { random- } \\
\text { ized com- } \\
\text { ponents }\end{array}$ & $\begin{array}{l}\text { Individualized outcome } \\
\text { feedback produced a } 48 \% \\
\text { reduction in monthly ex- } \\
\text { penditures for ondansetron } \\
\text { and droperidol }\end{array}$ \\
\hline 91 & 1999 & $\begin{array}{l}\text { describe the wari- } \\
\text { ation in prescrib- } \\
\text { ing indicators } \\
\text { determine wether } \\
\text { indicators associ- } \\
\text { ated with higher } \\
\text { or lower prescr. } \\
\text { costs; correlation } \\
\text { between indica- } \\
\text { tors, stability of } \\
\text { indicators in time }\end{array}$ & $\begin{array}{l}809 \text { gen- } \\
\text { eral prac- } \\
\text { tices in } \\
\text { Trent re- } \\
\text { gion of } \\
\text { England in } \\
1994 / 5\end{array}$ & $\begin{array}{l}\text { observa- } \\
\text { tional } \\
\text { study }\end{array}$ & $\begin{array}{l}\text { there are considerable: } \\
\text { variations between prac- } \\
\text { tices and over time, most } \\
\text { of the correlations were } \\
\text { not strong }\end{array}$ \\
\hline 93 & 1995 & $\begin{array}{l}\text { to study the effect: } \\
\text { of "academic } \\
\text { group detailing" } \\
\text { on prescribing } \\
\text { lipid-lowering } \\
\text { drugs }\end{array}$ & $\begin{array}{l}134 \text { pri- } \\
\text { mary care } \\
\text { community } \\
\text { health cen- } \\
\text { tres in } \\
\text { Sweden }\end{array}$ & $\begin{array}{l}\text { interventio } \\
n \text { - vs } \\
\text { control- } \\
\text { group }\end{array}$ & $\begin{array}{l}\text { guidelines for the manage- } \\
\text { ment of hyperlipidaemia } \\
\text { increased the prescription } \\
\text { of lipid-lowering drugs }\end{array}$ \\
\hline 101 & 1995 & $\begin{array}{l}\text { discussion about } \\
\text { brand-name } \\
\text { drugs vs generic } \\
\text { products }\end{array}$ & Canada & discussion & $\begin{array}{l}\text { generic drug-industry: } \\
\text { maximizing savings by } \\
\text { generic prescribing now } \\
\text { will enable health care } \\
\text { community to afford high } \\
\text { priced drugs of tomorrow; } \\
\text { brand-name drug compa- } \\
\text { nies. restricted price in- } \\
\text { creases are one of two } \\
\text { major hurdles for us }\end{array}$ \\
\hline 102 & 1993 & $\begin{array}{l}\text { to determine the } \\
\text { use of new drugs } \\
\text { (ACE-inhibitors, } \\
\text { broad spectrum } \\
\text { antibiotics and } \mathrm{H} 2 \\
\text { receptor } \\
\text { antagonists) in } \\
1988-91\end{array}$ & $\begin{array}{l}\text { all general } \\
\text { practices in } \\
\text { Northern } \\
\text { Ireland }\end{array}$ & $\begin{array}{l}\text { examina- } \\
\text { tion of data } \\
\text { on pre- } \\
\text { scribing } \\
\text { and calcu- } \\
\text { lation of } \\
\text { DDD per } \\
\text { month }\end{array}$ & $\begin{array}{l}\text { study suggests that the } \\
\text { profession has not inst- } \\
\text { tuted effective checks to } \\
\text { ensure that the legitimate } \\
\text { promotion of new prod- } \\
\text { ucts does not lead to inap- } \\
\text { propriate and wasteful use }\end{array}$ \\
\hline
\end{tabular}




\begin{tabular}{|c|c|c|c|c|c|}
\hline 103 & 1993 & $\begin{array}{l}\text { to find out why } \\
\text { the response rate } \\
\text { to requests to } \\
\text { GPs to supply } \\
\text { post-marketing } \\
\text { data on new } \\
\text { drugs has been } \\
\text { falling }\end{array}$ & $\begin{array}{l}543788 \\
\text { treatmenits } \\
\text { with } 27 \\
\text { PEM-drugs: } \\
1984-9 \text { by } \\
28402 \text { Gps } \\
\text { in England }\end{array}$ & $\begin{array}{l}\text { revilewing } \\
\text { dispensing } \\
\text { data }\end{array}$ & $\begin{array}{l}\text { prescribers were divided in } \\
6 \text { groups according to the } \\
\text { number of prescriptions for } \\
\text { the new drugs; } 42 \% \text { of the } \\
\text { prescriptions for new } \\
\text { drugs were concentrated } \\
\text { in the practices of } 10 \% \text { of } \\
\text { the doctors }\end{array}$ \\
\hline 104 & 1993 & $\begin{array}{l}\text { describe temporal } \\
\text { trends in prescrip- } \\
\text { tion drug use and } \\
\text { the determinants } \\
\text { of those trends }\end{array}$ & $\begin{array}{l}\text { British Co- } \\
\text { lumbia: } \\
1981-82 \text { vs } \\
1988-89\end{array}$ & $\begin{array}{l}\text { data from } \\
\text { prescrip- } \\
\text { tion drug } \\
\text { program } \\
\text { for the el- } \\
\text { derly }\end{array}$ & $\begin{array}{l}\text { drug expenditures under } \\
\text { the program increased } \\
317 \%, 34 \% \text { due to new } \\
\text { drugs, } 24 \% \text { to increased } \\
\text { age-specific utilization of } \\
\text { old drugs, } 21 \% \text { to in- } \\
\text { creased prices of old } \\
\text { drugs, } 14 \% \text { to the in- } \\
\text { creased size of the elderly } \\
\text { population; framework for } \\
\text { understanding and predict- } \\
\text { ing expenditures for drug } \\
\text { benefit plans }\end{array}$ \\
\hline 111 & 1994 & $\begin{array}{l}\text { evaluate appro- } \\
\text { priateness of } \\
\text { ciprofloxacine- } \\
\text { prescribing }\end{array}$ & $\begin{array}{l}\text { large aca- } \\
\text { demically } \\
\text { oriented } \\
\text { long-term } \\
\text { care facill- } \\
\text { ity; } 100 \text { ran- } \\
\text { domly se- } \\
\text { lected or- } \\
\text { ders over } 3 \\
\text { years }\end{array}$ & $\begin{array}{l}\text { retrospec- } \\
\text { tive chart } \\
\text { review in } \\
\text { population } \\
\text { of elderly } \\
\text { patients } \\
\text { (mean age } \\
\text { B8y) }\end{array}$ & $\begin{array}{l}\text { taking into account: indica- } \\
\text { tion, effectiveness and/or } \\
\text { price, only } 25 \% \text { of the or- } \\
\text { ders were judged appropri- } \\
\text { ate indicating, that pre- } \\
\text { scribing was less than op- } \\
\text { timal with potential conse- } \\
\text { quences of increased } \\
\text { health care costs }\end{array}$ \\
\hline 115 & 1997 & $\begin{array}{l}\text { to measure the } \\
\text { relative cost-ef- } \\
\text { fectiveness of } \\
\text { statines in a real- } \\
\text { world setting }\end{array}$ & Texas, US & $\begin{array}{l}\text { prospec- } \\
\text { tive, ran- } \\
\text { domized, } \\
\text { balanced } \\
\text { cohort de- } \\
\text { sign over } 6 \\
\text { months of } \\
\text { initial ther- } \\
\text { apy }\end{array}$ & $\begin{array}{l}\text { well designed formularies } \\
\text { should consider drug CE; } \\
\text { integration of the phar- } \\
\text { macy benefit management } \\
\text { with other medical man- } \\
\text { agement is essential : } \\
\text { fuvastatine may represent } \\
\text { a more cost effective for- } \\
\text { mulary choice among } \\
\text { statin products used for } \\
\text { initial monotherapy of hy- } \\
\text { percholesterolemia }\end{array}$ \\
\hline
\end{tabular}




\begin{tabular}{|c|c|c|c|c|c|}
\hline 142 & 1993 & $\begin{array}{l}\text { to review and pro- } \\
\text { vide critique of } \\
\text { the guidieline } \\
\text { which requires } \\
\text { from PCs a de- } \\
\text { tailed economic } \\
\text { analysis to sup- } \\
\text { port formulary } \\
\text { listing and subsi- } \\
\text { dization }\end{array}$ & Australia & $\begin{array}{l}\text { review } \\
\text { and expec- } \\
\text { tations of } \\
\text { the } \\
\text { authors }\end{array}$ & $\begin{array}{l}\text { the Guidelines raised the } \\
\text { level of awareness of the } \\
\text { need to integrate eco- } \\
\text { nomic analysis into formu- } \\
\text { lary approval process, but } \\
\text { by forcing drug evaluations } \\
\text { into a straightjacket run } \\
\text { the risk of undermining the } \\
\text { credibility and contribution } \\
\text { of economic analysis to } \\
\text { formulary decisions }\end{array}$ \\
\hline 152 & 1987 & $\begin{array}{l}\text { to describe the } \\
\text { introduction of a } \\
\text { drug formulary in } \\
\text { a three-doctor } \\
\text { general practice } \\
\text { and the effects on } \\
\text { prescribing costs }\end{array}$ & $\begin{array}{l}\text { Tayside } \\
\text { Scotland } \\
\text { UK, intro- } \\
\text { duction un } \\
1981\end{array}$ & $\begin{array}{l}\text { descriptive } \\
\text { study }\end{array}$ & $\begin{array}{l}\text { an increase of the propor- } \\
\text { tion of formulary drugs } \\
\text { was seen ( } 55 \% \rightarrow 60 \% \text { - } \\
62 \% \text { ); non-repeat } \\
\text { prescriptions reached } \\
78 \% \text {; cost savings both } \\
\text { per patient and per pre- } \\
\text { scription amounted } 10 \%\end{array}$ \\
\hline 161 & 1997 & $\begin{array}{l}\text { to compare pre- } \\
\text { scribing patterns } \\
\text { in general prac- } \\
\text { tice before and } \\
\text { after the introduc- } \\
\text { tion (1993) of } \\
\text { fundholding }\end{array}$ & $\begin{array}{l}\text { Northern } \\
\text { Ireland, } \\
\text { april } 1989 \text { - } \\
\text { march } \\
1996 ; 66 \\
\text { fundholders } \\
\text { (divided in } \\
\text { three } \\
\text { groups) } \\
\text { and } 268 \\
\text { non- } \\
\text { fundholders }\end{array}$ & $\begin{array}{l}\text { analysis of } \\
\text { data from } \\
\text { drug utili- } \\
\text { sation re- } \\
\text { search } \\
\text { units }\end{array}$ & $\begin{array}{l}\text { prescribing costs in- } \\
\text { creased in all groups; after } \\
\text { fundholders joined the } \\
\text { fundholding scheme their } \\
\text { pattern of prescribing } \\
\text { changed compared with } \\
\text { those of non-fundholders: } \\
\text { the rate of increase in } \\
\text { costs fell and there was a } \\
\text { significant rise in the rate } \\
\text { of generic prescribing }\end{array}$ \\
\hline
\end{tabular}


table 2.3 prescription (formulary, electronic/computerised prescribing system, discomfort in prescribing, feedback on prescription figures, specialists' prescriptions, (un)awareness in preseribing, quality in prescribing)

\begin{tabular}{|c|c|c|c|c|c|}
\hline ref. & year & objective & setting & design & results / comments \\
\hline \multicolumn{6}{|c|}{ formulary } \\
\hline 19 & 1995 & $\begin{array}{l}\text { to observe } 1 \mathrm{GPS} \\
\text { practice attempt to } \\
\text { reduce prescribing } \\
\text { costs through the } \\
\text { introduction of a } \\
\text { generic formulary } \\
\text { and to assess the } \\
\text { impact on patients } \\
\text { and prescribing } \\
\text { patterns }\end{array}$ & $\begin{array}{l}1 \text { urban } \\
\text { practice } \\
\text { with } 5 \text { part- } \\
\text { ners in } \\
\text { Scotland, } \\
1993\end{array}$ & $\begin{array}{l}\text { observa- } \\
\text { tional } \\
\text { study us- } \\
\text { ing inter- } \\
\text { views with } \\
\text { patients } \\
\text { and GPs } \\
\text { and using } \\
\text { searches } \\
\text { of repeat } \\
\text { prescrip- } \\
\text { tions to } \\
\text { identify } \\
\text { changes in } \\
\text { prescrip- } \\
\text { tion }\end{array}$ & $\begin{array}{l}\text { the practice achieved a } \\
\text { large reduction in prescrib- } \\
\text { ing costs rapidiy (onset } \\
\text { within } 4 \text { months) caused } \\
\text { by generic substitution and } \\
\text { a reduction of the volume } \\
\text { of treatment dispensed, } \\
\text { the changes were toler- } \\
\text { ated by patients, none of } \\
\text { whom is thought to have } \\
\text { left the practice for this } \\
\text { reason, great care must be } \\
\text { taken to inform patients } \\
\text { appropriately; }\end{array}$ \\
\hline 27 & 1994 & $\begin{array}{l}\text { to describe the } \\
\text { use of the Euro- } \\
\text { pean Formulary }\end{array}$ & $\begin{array}{l}15 \text { coun- } \\
\text { tries in Eu- } \\
\text { rope }\end{array}$ & $\begin{array}{l}\text { vision and } \\
\text { discussion }\end{array}$ & $\begin{array}{l}\text { too many drugs, lack of } \\
\text { transparency on the mar- } \\
\text { ket and a producer-ori- } \\
\text { ented drug information } \\
\text { cause poor prescribing; } \\
\text { a positive list will be estab- } \\
\text { lished with drug therapy- } \\
\text { recommendations for } 66 \\
\text { common diseases in prim. } \\
\text { care setting to facilitate rat- } \\
\text { ional choice of drugs and } \\
\text { improve patients outcome }\end{array}$ \\
\hline 32 & 1996 & $\begin{array}{l}\text { to audit the influ- } \\
\text { ence of a district } \\
\text { primary care drug } \\
\text { formulary on pre- } \\
\text { scribing by GPs }\end{array}$ & $\begin{array}{l}\text { Bedford- } \\
\text { shire, UK }\end{array}$ & $\begin{array}{l}50 \text { GPs } \\
\text { from } 11 \\
\text { practices } \\
\text { compared } \\
\text { with all } \\
\text { other GPs } \\
\text { in the } \\
\text { county }\end{array}$ & $\begin{array}{l}\text { the proportion of prescrip- } \\
\text { tion items for listed drugs } \\
\text { rose significantly in } 3 \\
\text { groups: cardiovasc, mus- } \\
\text { culloskeletal and obst./gyn. } \\
\text {; number of items per pre- } \\
\text { scribing fell significantly in } \\
3 \text { groups: musculoskeletal, } \\
\text { nervous and nutrition and } \\
\text { blood diseases; estimated } \\
\text { saving was f3000 per GP; } \\
\text { cost reduction sustained } \\
\text { over } 3 \text { years. }\end{array}$ \\
\hline
\end{tabular}




\begin{tabular}{|c|c|c|c|c|c|}
\hline 47 & 1992 & $\begin{array}{l}\text { to determine the } \\
\text { pattern of drug } \\
\text { use for all drugs in } \\
\text { the ltalian National } \\
\text { Formulary }\end{array}$ & $\begin{array}{l}3866 \text { GPs } \\
\text { Northern } \\
\text { Italy }\end{array}$ & $\begin{array}{l}\text { data analy- } \\
\text { sis of pre- } \\
\text { scriptions } \\
\text { for all } \\
\text { drugs in } \\
1988 / 89\end{array}$ & $\begin{array}{l}\text { slight increase in total drug } \\
\text { prescr. and greater } \\
\text { change in those recently } \\
\text { marketed; in comparison } \\
\text { to other countries there } \\
\text { was over prescription of } \\
\text { H2-antagonists, ACE-in- } \\
\text { hibitors, Ca antagonists } \\
\text { and chol. inhibitors; fre- } \\
\text { quent prescribing of drugs } \\
\text { lacking documentation of } \\
\text { clinical efficacy; educa- } \\
\text { tional intervention is } \\
\text { needed to improve the } \\
\text { quality of drug prescribing }\end{array}$ \\
\hline 55 & 1996 & $\begin{array}{l}\text { to gain insight into } \\
\text { the current use of } \\
\text { EDL-products by } \\
\text { GPs }\end{array}$ & $\begin{array}{l}\text { South Af- } \\
\text { rica }\end{array}$ & $\begin{array}{l}\text { reviewing } \\
120.000 \\
\text { prescrip- } \\
\text { tions }\end{array}$ & $\begin{array}{l}22,4 \% \text { of current GP pre- } \\
\text { scriptions included EDL } \\
\text { items, } 19,6 \% \text { included } \\
\text { other forms of EDL items } \\
\text { this gap between EDL and } \\
\text { prescribed drugs indicates } \\
\text { necessary discussion }\end{array}$ \\
\hline 61 & 1994 & $\begin{array}{l}\text { to describe the } \\
\text { development and } \\
\text { implementation of } \\
\text { a list of } \\
\text { recommended } \\
\text { drugs }\end{array}$ & $\begin{array}{l}125 \text { GPs at } \\
27 \text { health } \\
\text { centres in } \\
\text { the south } \\
\text { west re- } \\
\text { gion of } \\
\text { Stockholm, } \\
\text { Sweden }\end{array}$ & & $\begin{array}{l}\text { GPs started a process to- } \\
\text { wards rationall prescribing } \\
\text { with the help of local phar- } \\
\text { macists providing prescrib- } \\
\text { ing data; a list of } 167 \text { rec- } \\
\text { ommended drugs was de- } \\
\text { veloped; cost cautious- } \\
\text { ness seemed to increase, } \\
\text { volume per prescription } \\
\text { decreased and costs were } \\
20 \% \text { below the national } \\
\text { prescribing pattern }\end{array}$ \\
\hline 71 & 1992 & $\begin{array}{l}\text { to study the effect } \\
\text { of the introduction } \\
\text { without continued } \\
\text { reinforcement of a } \\
\text { voluntary practice } \\
\text { formulary on } \\
\text { antimicrobial pre- } \\
\text { scribing in a group } \\
\text { practice }\end{array}$ & UK & $\begin{array}{l}\text { detailed } \\
\text { prescribing } \\
\text { feedback } \\
\text { for two } \\
\text { matched } \\
\text { periods, } \\
\text { before and } \\
\text { after the } \\
\text { launch of } \\
\text { the formu- } \\
\text { lary was } \\
\text { compared }\end{array}$ & $\begin{array}{l}\text { parameters were: adher- } \\
\text { ence to the formulary, ge- } \\
\text { neric prescribing and } \\
\text { costs; the high levell of for- } \\
\text { mulary prescribing preva- } \\
\text { lent during the production } \\
\text { of the formulary was not } \\
\text { maintained following its } \\
\text { launch, probably because } \\
\text { of the lack of reinforce- } \\
\text { ment; prescribing costs } \\
\text { increased by } 32 \%\end{array}$ \\
\hline
\end{tabular}




\begin{tabular}{|c|c|c|c|c|c|}
\hline 97 & 1994 & $\begin{array}{l}\text { leam about the } \\
\text { experience of the } \\
\text { users of the } \\
\text { Gottingen formu- } \\
\text { lary }\end{array}$ & $\begin{array}{l}830 \mathrm{~g} \text { Ps } \\
\text { in ger- } \\
\text { many, re- } \\
\text { sponse: } \\
223\end{array}$ & $\begin{array}{l}\text { semi-struc- } \\
\text { tured } \\
\text { question- } \\
\text { naires }\end{array}$ & $\begin{array}{l}\text { the majority of the respon- } \\
\text { dents were satisfied or } \\
\text { very satisfied with the } \\
\text { drugs selected; } 67 \% \text { indi- } \\
\text { cated, that the use had } \\
\text { changed their prescribing } \\
\text { habits; } 70 \% \text { appreciated } \\
\text { an official positive list }\end{array}$ \\
\hline 101 & 1995 & $\begin{array}{l}\text { discussion about } \\
\text { brand-name drugs } \\
\text { vs generic prod- } \\
\text { ucts }\end{array}$ & Canada & discussion & $\begin{array}{l}\text { drug formularies limiting } \\
\text { the } \mathrm{mr} \text {, of new drugs, are a } \\
\text { major hurdle for brand- } \\
\text { name drug companies }\end{array}$ \\
\hline 114 & 1997 & $\begin{array}{l}\text { to determine } \\
\text { whether the intro- } \\
\text { duction of pre- } \\
\text { scribing formular- } \\
\text { les helps GPs to } \\
\text { prescribe from a } \\
\text { narrower range of } \\
\text { NSAID's }\end{array}$ & $\begin{array}{l}\text { Lincoln- } \\
\text { shire, UK }\end{array}$ & $\begin{array}{l}\text { compared } \\
\text { interven- } \\
\text { tion study; } \\
\text { introduc- } \\
\text { tion of a } \\
\text { formulary } \\
\text { in } 10 \text { prac- } \\
\text { tices with } \\
\text { matched } \\
\text { controls }\end{array}$ & $\begin{array}{l}\text { following the development } \\
\text { of a formulary for NSAIDs, } \\
\text { practices prescribed from } \\
\text { a narrower range of drugs } \\
\text { and focussed a greater } \\
\text { proportion of their pre- } \\
\text { scribing on their three } \\
\text { most commonly used } \\
\text { drugs }\end{array}$ \\
\hline 133 & 1994 & $\begin{array}{l}\text { to identify areas of } \\
\text { growth ini cardio- } \\
\text { vascular drugs } \\
\text { and problem ar- } \\
\text { eas where pre- } \\
\text { scribing expensive } \\
\text { formulations led to } \\
\text { dramatic increase } \\
\text { in costs }\end{array}$ & $\begin{array}{l}\text { West Mid- } \\
\text { lands, UK }\end{array}$ & $\begin{array}{l}\text { analysis of } \\
\text { prescrip- } \\
\text { tions from } \\
\text { pharma- } \\
\text { cists send- } \\
\text { ing data to } \\
\text { a central } \\
\text { point for } \\
\text { reimburse- } \\
\text { ment }\end{array}$ & $\begin{array}{l}\text { prescriptions from pharma- } \\
\text { cists sending dala to a } \\
\text { central point for reimburse- } \\
\text { ment are a valuable tool in } \\
\text { assessment of prescribing } \\
\text { habits and can be used by } \\
\text { GP when preparing a for- } \\
\text { mulary }\end{array}$ \\
\hline 136 & 1994 & $\begin{array}{l}\text { to consider the } \\
\text { problem of making } \\
\text { the best use of } \\
\text { limited available } \\
\text { resources to attain } \\
\text { the highest quality } \\
\text { for the lowest cost. } \\
\text { particularty in } \\
\text { formulary-deci- } \\
\text { sions }\end{array}$ & $\begin{array}{l}\text { US of } \\
\text { America }\end{array}$ & $\begin{array}{l}\text { problem } \\
\text { description } \\
\text { and litera- } \\
\text { ture based } \\
\text { sugges- } \\
\text { tions for } \\
\text { solutions }\end{array}$ & $\begin{array}{l}\text { pharmaco-economic data } \\
\text { have become increasingly } \\
\text { available and will be play- } \\
\text { ing a major role in formu- } \\
\text { lary decisions in many } \\
\text { countries around the world }\end{array}$ \\
\hline
\end{tabular}




\begin{tabular}{|c|c|c|c|c|c|}
\hline 152 & 1987 & $\begin{array}{l}\text { to describe the } \\
\text { introduction of a } \\
\text { drug formulary in a } \\
\text { three-doctor gen- } \\
\text { eral practice and } \\
\text { the effects on pre- } \\
\text { scribing costs }\end{array}$ & $\begin{array}{l}\text { Tayside, } \\
\text { Scotiand } \\
\text { UK, intro- } \\
\text { duction in } \\
1981\end{array}$ & $\begin{array}{l}\text { descriptive } \\
\text { studly }\end{array}$ & $\begin{array}{l}\text { an increase of the propor- } \\
\text { tion of formulary drugs } \\
\text { was seen ( } 55 \% \rightarrow 60 \% \rightarrow \\
62 \%) \text {; non-repeat prescrip- } \\
\text { tions reached } 78 \% \text {; cost } \\
\text { savings both per patient } \\
\text { and per prescription } \\
\text { amounted } 10 \%\end{array}$ \\
\hline 154 & 1998 & $\begin{array}{l}\text { to determine the } \\
\text { influence of GPs' } \\
\text { outpatient medica- } \\
\text { tion on non-formu- } \\
\text { lary drug requests } \\
\text { in university hospi- } \\
\text { tals }\end{array}$ & $\begin{array}{l}\text { Gottingen, } \\
\text { Germany }\end{array}$ & $\begin{array}{l}1 \text { year re- } \\
\text { viewing } \\
\text { every non- } \\
\text { formulary } \\
\text { drug re- } \\
\text { quest }\end{array}$ & $\begin{array}{l}\text { non-formulary requests } \\
\text { attributable to previous } \\
\text { outpatient medication ac- } \\
\text { counts for less than } 20 \% \text {; } \\
\text { a minor portion of them } \\
\text { lack scientific proof of effi- } \\
\text { cacy; the hospital should } \\
\text { avoid a too restrictive drug } \\
\text { policy ; request justified } \\
\text { especially in the depart- } \\
\text { ment of psychiatry }\end{array}$ \\
\hline 155 & 1999 & $\begin{array}{l}\text { to study the suc- } \\
\text { cess of the model. } \\
\text { of consultation by } \\
\text { GPs and pharma- } \\
\text { cists in Asten }\end{array}$ & $\begin{array}{l}\text { Asten, The } \\
\text { Nether- } \\
\text { lands }\end{array}$ & interviews & $\begin{array}{l}\text { bottom-up consultation in } \\
\text { PTAMs in Asten resulting } \\
\text { in a computer-based for- } \\
\text { mulary together with com- } \\
\text { bining the knowledge and } \\
\text { expertise of GPs and phar- } \\
\text { macists and independence } \\
\text { from PCs make the Asten } \\
\text { modiel a success; the low } \\
\text { number of prescriptions } \\
\text { per patient and the low } \\
\text { costs per prescription } \\
\text { show this success }\end{array}$ \\
\hline \multicolumn{6}{|c|}{ electronic prescribing system / support by computers } \\
\hline 18 & 1986 & $\begin{array}{l}\text { to describe the } \\
\text { use of and the } \\
\text { improvements by } \\
\text { prescribing by } \\
\text { computer }\end{array}$ & UK & $\begin{array}{l}\text { analysis of } \\
\text { own prac- } \\
\text { tice pre- } \\
\text { scriptions }\end{array}$ & $\begin{array}{l}\text { the improvements were: } \\
\text { more safety, time saving, } \\
\text { decreasing costs and an } \\
\text { instant audit of all impor- } \\
\text { tant prescribing parame- } \\
\text { ters, more rational treat- } \\
\text { ment and improved ser- } \\
\text { vice for patients; } 31 \% \\
\text { were repeat prescriptions; } \\
\text { savings in costs do not } \\
\text { seem likely, unless a lim- } \\
\text { ited drug formulary is used }\end{array}$ \\
\hline
\end{tabular}




\begin{tabular}{|c|c|c|c|c|c|}
\hline 53 & 1996 & $\begin{array}{l}\text { to compare the } \\
\text { author's prescrib- } \\
\text { ing habits for anti- } \\
\text { biotics in two dif- } \\
\text { ferent work set- } \\
\text { tings and to study } \\
\text { the reasons for the } \\
\text { observed different } \\
\text { trends }\end{array}$ & $\begin{array}{l}\text { in Scandi- } \\
\text { navia in a } \\
\text { solo prac- } \\
\text { tice in a } \\
\text { fishing vil- } \\
\text { lage over } \\
1984-87 \\
\text { and a } \\
\text { group } \\
\text { practice in } \\
\text { a town } \\
\text { over } 1987- \\
92\end{array}$ & $\begin{array}{l}\text { a retro- } \\
\text { spective } \\
\text { database } \\
\text { study of } \\
\text { computer- } \\
\text { based pa- } \\
\text { tient re- } \\
\text { cords }\end{array}$ & $\begin{array}{l}\text { in solo-practice the GP } \\
\text { reduced the nr. of pre- } \\
\text { scriptions for antibiotics } \\
\text { significantly from } 82.9 \text { to } \\
63.8 \text { per } 1000 \text { contacts; in } \\
\text { group practice the nr. in- } \\
\text { creased from } 82.6 \text { to } 90.5 \\
\text { (NS); increase of workload } \\
\text { during the (latter) study } \\
\text { period(s), with a looser } \\
\text { affiliation to the patient } \\
\text { group; GPs should be able } \\
\text { to reduce prescriptions for } \\
\text { antibiotics if interested in } \\
\text { doing so; computer based } \\
\text { quality control essential, } \\
\text { because expectations of } \\
\text { the patients and work envi- } \\
\text { ronment of the doctor de- } \\
\text { termine to a great extent } \\
\text { his antibiotic prescribing } \\
\text { habits }\end{array}$ \\
\hline 153 & 1995 & $\begin{array}{l}\text { to support the in- } \\
\text { troduction of the } \\
\text { electronic version } \\
\text { of the BNF }\end{array}$ & $\begin{array}{l}\text { UK of Brit- } \\
\text { ain }\end{array}$ & $\begin{array}{l}\text { consider- } \\
\text { ations }\end{array}$ & $\begin{array}{l}\text { computer based prescrib- } \\
\text { ing and more sophisticated } \\
\text { decision support tools ilm- } \\
\text { proved drug choices, ac- } \\
\text { curacy of drug dosing and } \\
\text { saved time in repeat pre- } \\
\text { scriptions and costs; the } \\
\text { electronic BNF contains } \\
\text { full text of the paper ver- } \\
\text { sion; it will be structured as } \\
\text { a decision tool later }\end{array}$ \\
\hline 155 & 1999 & $\begin{array}{l}\text { to study the suc- } \\
\text { cess of the model } \\
\text { of consultation by } \\
\text { GPs and pharma- } \\
\text { cists in Asten }\end{array}$ & $\begin{array}{l}\text { Asten, The } \\
\text { Nether- } \\
\text { lands }\end{array}$ & interviews & $\begin{array}{l}\text { bottom-up consultation in } \\
\text { PTAMs in Asten resulting } \\
\text { in a computer-based for- } \\
\text { mulary together with com- } \\
\text { bining the knowledge and } \\
\text { expertise of GPs and phar- } \\
\text { macists and independence } \\
\text { from PCs make the Asten } \\
\text { model a success; the low } \\
\text { number of prescriptions } \\
\text { per patient and the low } \\
\text { costs per prescription } \\
\text { show this success }\end{array}$ \\
\hline
\end{tabular}




\begin{tabular}{|c|c|c|c|c|c|}
\hline \multicolumn{6}{|c|}{ discomfort in prescribing } \\
\hline 10 & 1992 & $\begin{array}{l}\text { to explore the dis- } \\
\text { comfort experi- } \\
\text { enced by GPs in } \\
\text { relation to deci- } \\
\text { sions about } \\
\text { wether or not to } \\
\text { prescribe }\end{array}$ & $\begin{array}{l}1 \text { family } \\
\text { practitioner } \\
\text { committee } \\
\text { in the } \\
\text { north of } \\
\text { England }\end{array}$ & $\begin{array}{l}\text { focussed } \\
\text { interviews } \\
\text { with } 74 \\
\text { respon- } \\
\text { dents ( } 69 \\
\text { principal } \\
\text { GPs, } 5 \\
\text { trainee } \\
\text { GPs) }\end{array}$ & $\begin{array}{l}\text { any drug and any condition } \\
\text { could be associated with } \\
\text { discomfort; patient expec- } \\
\text { tation, clinical appropriate- } \\
\text { ness, doctor-patient- rela- } \\
\text { tionship and precedents } \\
\text { were main reasons for } \\
\text { made decisions; concern } \\
\text { about drug toxicity, failure } \\
\text { to live up to the GP's own } \\
\text { expectations, concern } \\
\text { about the appropriateness } \\
\text { of treatment, ignorance or } \\
\text { uncertainty were main rea- } \\
\text { sons for feeling uncomfort- } \\
\text { able; many considerations } \\
\text { (medical, social and logis- } \\
\text { tic) influence decision, final } \\
\text { action depends on com- } \\
\text { plex interaction of sepa- } \\
\text { rate influences }\end{array}$ \\
\hline 111 & 1995 & $\begin{array}{l}\text { to identify patients } \\
\text { in the practice with } \\
\text { inappropriate } \\
\text { medication }\end{array}$ & $\begin{array}{l}\text { GPs' prac- } \\
\text { tice admin- } \\
\text { istrations }\end{array}$ & $\begin{array}{l}7 \mathrm{GPs} \\
\text { used vari- } \\
\text { ous } \\
\text { methods }\end{array}$ & $\begin{array}{l}25 \text { different drugs for } 40 \\
\text { patients identified inappro- } \\
\text { priate with current knowl- } \\
\text { edge; almost half the pa- } \\
\text { tients might consider } \\
\text { changing their medication, } \\
\text { community pharmacists } \\
\text { could help in reviewing } \\
\text { long-term medication }\end{array}$ \\
\hline 13 & 1998 & $\begin{array}{l}\text { to better under- } \\
\text { stand reasans for } \\
\text { antibiotics being } \\
\text { prescribed for sore } \\
\text { throats despite } \\
\text { well known evi- } \\
\text { dence that they } \\
\text { are generally of } \\
\text { little help }\end{array}$ & $\begin{array}{l}21 \text { GPs in } \\
\text { general } \\
\text { practices } \\
\text { in South } \\
\text { Wales and } \\
17 \text { patients. }\end{array}$ & $\begin{array}{l}\text { qualitative } \\
\text { study with } \\
\text { semi-struc- } \\
\text { tured inter- } \\
\text { views }\end{array}$ & $\begin{array}{l}\text { GPs often prescribed for } \\
\text { good relationships with } \\
\text { patients; most GPs found } \\
\text { prescribing "against the } \\
\text { evidence uncomfortable } \\
\text { and realised this probably } \\
\text { increased workload }\end{array}$ \\
\hline
\end{tabular}




\begin{tabular}{|c|c|c|c|c|c|}
\hline 108 & 1993 & $\begin{array}{l}\text { to determine the } \\
\text { effect of three } \\
\text { types of interac- } \\
\text { tions between } \\
\text { GPS and pharma- } \\
\text { ceutical compa- } \\
\text { nies }\end{array}$ & $\begin{array}{l}2227 \text { pa- } \\
\text { pers re- } \\
\text { viewed } \\
\text { within cri- } \\
\text { teria: } 36 \\
\text { studlies } \\
\text { matched }\end{array}$ & $\begin{array}{l}\text { literature } \\
\text { search } \\
1978- \\
1993\end{array}$ & $\begin{array}{l}\text { many GPs have concerns } \\
\text { about accepting money } \\
\text { from PCs for clinical trials; } \\
\text { GPs are affected by their } \\
\text { interactions with PCs }\end{array}$ \\
\hline \multicolumn{6}{|c|}{ feedback on prescribing figures } \\
\hline 11 & 1995 & $\begin{array}{l}\text { to identify patients } \\
\text { in the practice with } \\
\text { inappropriate } \\
\text { medication }\end{array}$ & $\begin{array}{l}\text { GPs' prac- } \\
\text { tice admin- } \\
\text { istrations }\end{array}$ & $\begin{array}{l}7 \text { GPs } \\
\text { used vari- } \\
\text { ous } \\
\text { methods }\end{array}$ & $\begin{array}{l}25 \text { different drugs for } 40 \\
\text { patients were identified as } \\
\text { inappropriate prescribing; } \\
\text { almost half of the patients } \\
\text { might consider changing } \\
\text { their medication, commu- } \\
\text { nity pharmacists could } \\
\text { help in reviewing long-term } \\
\text { medication }\end{array}$ \\
\hline 34 & 1999 & $\begin{array}{l}\text { to assess the ef- } \\
\text { fectiveness of a } \\
\text { mailed interven- } \\
\text { tion combining } \\
\text { confidential pre- } \\
\text { scribing feedback } \\
\text { with targeted edu- } \\
\text { cational bulletins } \\
\text { in increasing the } \\
\text { use of less expen- } \\
\text { sive, fist-line anti- } \\
\text { biotics by GPs }\end{array}$ & $\begin{array}{l}251 \text { GPs } \\
\text { from } \\
\text { Southern } \\
\text { Ontario: } \\
135 \text { inter- } \\
\text { vention } \\
\text { and } 116 \text { in } \\
\text { control } \\
\text { group }\end{array}$ & & $\begin{array}{l}\text { prescribing data were col- } \\
\text { lected from the claims da- } \\
\text { tabase; feedback took } \\
\text { place every } 2 \text { - } 6 \text { months; } \\
\text { costs rose in the control } \\
\text { group and remained con- } \\
\text { stant in the feedback- } \\
\text { group; first-line drug use } \\
\text { increased in the feedback } \\
\text { group but decreased in the } \\
\text { feedback group; } 82 \% \text { of the } \\
\text { GPs in the feed back } \\
\text { group would readilly partici- } \\
\text { pate in another, similar } \\
\text { program }\end{array}$ \\
\hline 71 & 1992 & $\begin{array}{l}\text { to study the effect } \\
\text { of the introduction } \\
\text { without continued } \\
\text { reinforcement of a } \\
\text { voluntary practice } \\
\text { formulary on } \\
\text { antimicrobial pre- } \\
\text { scribing in a group } \\
\text { practice }\end{array}$ & UK & $\begin{array}{l}\text { detailed } \\
\text { prescribing } \\
\text { feedback } \\
\text { for two } \\
\text { matched } \\
\text { periods, } \\
\text { before and } \\
\text { after the } \\
\text { launch of } \\
\text { the formu- } \\
\text { lary was } \\
\text { compared }\end{array}$ & $\begin{array}{l}\text { parameters were: adher- } \\
\text { ence to the formulary, ge- } \\
\text { neric prescribing and } \\
\text { costs; the high level of for- } \\
\text { mulary prescribing preva- } \\
\text { lent during the production } \\
\text { of the formulary was not } \\
\text { maintained following its } \\
\text { launch, probably because } \\
\text { of the lack of reinforce- } \\
\text { ment; prescribing costs in- } \\
\text { creased by } 32 \%\end{array}$ \\
\hline
\end{tabular}




\begin{tabular}{|c|c|c|c|c|c|}
\hline 146 & 1999 & $\begin{array}{l}\text { to evaluate the } \\
\text { effect on GPs" pre- } \\
\text { scribing of feed- } \\
\text { back on their lev- } \\
\text { els of prescription }\end{array}$ & $\begin{array}{l}\text { general } \\
\text { practice in } \\
\text { rural Aus- } \\
\text { tralia; } \\
2440 \text { GPs }\end{array}$ & $\begin{array}{l}\text { random- } \\
\text { ised con- } \\
\text { trolled trial }\end{array}$ & $\begin{array}{l}\text { this feed-back (mailed, } \\
\text { unsolicited, centralised, } \\
\text { govermment sponsored } \\
\text { and based on aggregate } \\
\text { data) had no impact on the } \\
\text { prescribing levels of GPs; } \\
\text { no reduced variability in } \\
\text { prescribing, nor affect on } \\
\text { very high or very low pre- } \\
\text { scribers }\end{array}$ \\
\hline \multicolumn{6}{|c|}{ specialists' prescriptions } \\
\hline 22 & 1993 & $\begin{array}{l}\text { differentiation be- } \\
\text { tween prescrip- } \\
\text { tions of GPs origi- } \\
\text { nally initiated by } \\
\text { hospital doctors } \\
\text { and prescriptions } \\
\text { originally initiated } \\
\text { by the GPs them- } \\
\text { selves }\end{array}$ & $\begin{array}{l}27 \text { GPs } \\
\text { and } 1.471 \\
\text { prescribed } \\
\text { items }\end{array}$ & $\begin{array}{l}\text { GPs } \\
\text { indicate on } \\
30 \text { pre- } \\
\text { scriptions } \\
\text { originally } \\
\text { prescribed } \\
\text { whether } \\
\text { they agree } \\
\text { with hosp. } \\
\text { doctors }\end{array}$ & $\begin{array}{l}63 \% \text { of the items initiated } \\
\text { by GPs, } 35 \% \text { of the items } \\
\text { by hospital doctors, } 2 \% \text { of } \\
\text { the items unknown; GPs } \\
\text { agreed with most of the } \\
\text { hospital initiated items }\end{array}$ \\
\hline 63 & 1996 & $\begin{array}{l}\text { to determine to } \\
\text { what extent GP's' } \\
\text { prescribing behav- } \\
\text { iour is a result of } \\
\text { repeat prescription } \\
\text { of medication } \\
\text { which has been } \\
\text { initiated by spe- } \\
\text { cialists }\end{array}$ & $\begin{array}{l}\text { six phar- } \\
\text { macies in } \\
\text { the north- } \\
\text { eastern } \\
\text { part of the } \\
\text { Nether- } \\
\text { lands }\end{array}$ & $\begin{array}{l}\text { pharma- } \\
\text { cists iden- } \\
\text { tified GPs' } \\
\text { prescrip- } \\
\text { tions } \\
\text { during } 1 \\
\text { month; } \\
1648 \\
\text { question- } \\
\text { naires to } \\
44 \text { GPs, } \\
\text { response } \\
1342 \\
(81 \%)\end{array}$ & $\begin{array}{l}\text { of drugs for cardiovascular } \\
\text { therapy that GPs pre- } \\
\text { scribed, } 66 \% \text { had originally } \\
\text { been prescribed by spe- } \\
\text { cialists; qualitative studies } \\
\text { should be made of the ap- } \\
\text { propriateness of chronic } \\
\text { medication, initiated by } \\
\text { specialists an continued in } \\
\text { repeat prescribing by GPS. }\end{array}$ \\
\hline \multicolumn{6}{|c|}{ (Un)awareness in prescribing } \\
\hline 6 & 1998 & $\begin{array}{l}\text { to revue issues of } \\
\text { legal liability in } \\
\text { prescribing choice }\end{array}$ & $\begin{array}{l}\text { antidepre } \\
\text { ssants in } \\
\text { psychiatry }\end{array}$ & $\begin{array}{l}\text { review } \\
\text { with partic- } \\
\text { ular refer- } \\
\text { ence to } \\
\text { prescribing } \\
\text { antidepres } \\
\text { sants }\end{array}$ & $\begin{array}{l}\text { adverse outcome of a } \\
\text { treatment raises the poten- } \\
\text { tial of professional negli- } \\
\text { gence claims to be } \\
\text { brought against medical } \\
\text { practitioners who prescribe } \\
\text { certain medicines of equal } \\
\text { efficacy for reasons other } \\
\text { than established medical } \\
\text { need }\end{array}$ \\
\hline
\end{tabular}




\begin{tabular}{|c|c|c|c|c|c|}
\hline 16 & 1999 & $\begin{array}{l}\text { Insight into the } \\
\text { reasons for actual } \\
\text { prescribing of anti- } \\
\text { biotics for acute } \\
\text { otitis media }\end{array}$ & $\begin{array}{l}70 \text { antibi- } \\
\text { otic pre- } \\
\text { scriptions } \\
\text { by } 22 \\
\text { Dutch GPs } \\
\text { were eval- } \\
\text { Uated }\end{array}$ & $\begin{array}{l}\text { discussion } \\
\text { in stimu- } \\
\text { lated recall } \\
\text { interviews }\end{array}$ & $\begin{array}{l}77 \% \text { of the prescriptions } \\
\text { did not follow the NHG- } \\
\text { guidelines; medical and } \\
\text { non-medical reasons; the } \\
\text { impact of GPs' awareness } \\
\text { of the latter should be in- } \\
\text { vestigated further. }\end{array}$ \\
\hline 36 & 1998 & $\begin{array}{l}\text { to gain more in- } \\
\text { sight in the prob- } \\
\text { lem concerning } \\
\text { drug choice and } \\
\text { recommendation }\end{array}$ & $\begin{array}{l}\text { The Neth- } \\
\text { erlands }\end{array}$ & $\begin{array}{l}\text { an analy- } \\
\text { sis of the } \\
\text { averall } \\
\text { drug } \\
\text { choice pro- } \\
\text { cess }\end{array}$ & $\begin{array}{l}\text { a cognitive model illustr- } \\
\text { ates nature, complexity } \\
\text { and dynamical feature of } \\
\text { the drug choice process } \\
\text { reveals factors involved } \\
\text { and may shed light on na- } \\
\text { ture and causes of } \\
\text { selection problems }\end{array}$ \\
\hline 37 & 1998 & $\begin{array}{l}\text { to analyse the } \\
\text { drug choice proce- } \\
\text { dure }\end{array}$ & $\begin{array}{l}\text { The Neth- } \\
\text { erlands }\end{array}$ & $\begin{array}{l}\text { an analy- } \\
\text { sis of the } \\
\text { bottle- } \\
\text { necks in } \\
\text { the drug } \\
\text { choice pro- } \\
\text { cess }\end{array}$ & $\begin{array}{l}\text { three categories recog- } \\
\text { nised and solutions sug- } \\
\text { gested: } 1 \text {. pharmaco- } \\
\text { therapeutic knowledge of } \\
\text { GPs and pharmacists / } \\
\text { (post-graduate) education; } \\
\text { 2. accessibility and value } \\
\text { of drug-infiormation/ readily } \\
\text { accessible data-base } 3 \text {. } \\
\text { subjective influences/ } \\
\text { discussion- and decision } \\
\text { procedures }\end{array}$ \\
\hline 56 & 1999 & $\begin{array}{l}\text { to argue that anal- } \\
\text { yses of the overall } \\
\text { system of events } \\
\text { which are imple- } \\
\text { mented to improve } \\
\text { medication use } \\
\text { are needed }\end{array}$ & Australia & $\begin{array}{l}\text { a case } \\
\text { study of a } \\
\text { sequence } \\
\text { of events } \\
\text { which led } \\
\text { to changes } \\
\text { in the utili- } \\
\text { sation of } \\
\text { flucloxa- } \\
\text { cillin }\end{array}$ & $\begin{array}{l}\text { effectiveness of individual } \\
\text { interventions dependent } \\
\text { on concurrently and previ- } \\
\text { ously implemented initia- } \\
\text { tives; changes in use of } \\
\text { flucloxacillin resulted from } \\
\text { both regulatory interven- } \\
\text { tions that raised the } \\
\text { awareness of the adverse } \\
\text { hepatic reaction and the } \\
\text { promotion of appropriate } \\
\text { alternative therapies; the } \\
\text { methodology provides } \\
\text { understanding of each ini- } \\
\text { tiative in the overall sys- } \\
\text { tem of activities which sup- } \\
\text { port quality use of medi- } \\
\text { cines }\end{array}$ \\
\hline
\end{tabular}




\begin{tabular}{|c|c|c|c|c|c|}
\hline 57 & 1998 & $\begin{array}{l}\text { to identify predic- } \\
\text { tors of antidepres- } \\
\text { sant pharmaco } \\
\text { therapy among } \\
\text { patients diag- } \\
\text { nosed with de- } \\
\text { pression and pre- } \\
\text { dictors of prescrip- } \\
\text { tion for SSRI or } \\
\text { SNRI }\end{array}$ & $\begin{array}{l}18.046 .29 \\
3 \text { office- } \\
\text { based } \\
\text { visits } \\
\text { resulting in } \\
\text { the } \\
\text { diagnosis } \\
\text { of } \\
\text { depression }\end{array}$ & $\begin{array}{l}\text { data from } \\
\text { the } 1995 \\
\text { NAMCS to } \\
\text { discern } \\
\text { variables: } \\
\text { age, race, } \\
\text { gender. } \\
\text { selif-report } \\
\text { of } \\
\text { depression } \\
\text { type of } \\
\text { pay }\end{array}$ & $\begin{array}{l}\text { the pattem of prescribing } \\
\text { antidepressant pharmaco } \\
\text { therapy is influenced by a } \\
\text { patients' age, gender, self- } \\
\text { report of depression and } \\
\text { type of insurance } \\
\text { coverage }\end{array}$ \\
\hline 72 & 1999 & $\begin{array}{l}\text { to investigate the } \\
\text { relevance of the } \\
\text { influence of the } \\
\text { attraction effect to } \\
\text { physicians } \\
\text { medication } \\
\text { prescribing } \\
\text { decisions }\end{array}$ & $\begin{array}{l}40 \text { internal } \\
\text { medicine } \\
\text { residents } \\
\text { each } \\
\text { reviewing } \\
\text { three } \\
\text { patient } \\
\text { cases }\end{array}$ & $\begin{array}{l}\text { comparing } \\
\text { two } \\
\text { versions of } \\
\text { cases; a } \\
\text { choice out } \\
\text { of } 2 \text { or } 3 \\
\text { drugs ( } 1 \text { : } \\
\text { target drug } \\
=\text { best; } 2 \text { : } \\
\text { competitor } \\
=\text { second } \\
\text { best; } 3: \\
\text { decoy }= \\
\text { inferior) }\end{array}$ & $\begin{array}{l}\text { introduction of the "decoy" } \\
\text { medication increased the } \\
\text { likelihood of choosing the } \\
\text { target medication; } \\
\text { physicians should be } \\
\text { aware of this attraction } \\
\text { effect when evaluating or } \\
\text { suggesting several } \\
\text { similarly attractive } \\
\text { medications or treatment } \\
\text { options for the same } \\
\text { medical condition }\end{array}$ \\
\hline 107 & 1994 & $\begin{array}{l}\text { promoting rational } \\
\text { prescribing on } \\
\text { behal of } \\
\text { hypnosedative } \\
\text { drugs }\end{array}$ & $\begin{array}{l}137 \text { GPs in } \\
\text { New South } \\
\text { Wales }\end{array}$ & $\begin{array}{l}\text { controlled } \\
\text { trial of an } \\
\text { educa- } \\
\text { tional } \\
\text { interventio } \\
n\end{array}$ & $\begin{array}{l}\text { self-rating of } \\
\text { benzodiazepine } \\
\text { prescribing greatly } \\
\text { underestimated actual } \\
\text { self-reported incidents of } \\
\text { prescribing }\end{array}$ \\
\hline 108 & 1993 & $\begin{array}{l}\text { to determine the } \\
\text { effect of three } \\
\text { types of } \\
\text { interactions } \\
\text { between GPs and } \\
\text { pharmaceutical } \\
\text { companies }\end{array}$ & $\begin{array}{l}2227 \\
\text { papers } \\
\text { reviewed } \\
\text { within } \\
\text { criteria: } 36 \\
\text { studies } \\
\text { matched }\end{array}$ & $\begin{array}{l}\text { literature } \\
\text { search } \\
1978 \text { - } \\
1993\end{array}$ & $\begin{array}{l}\text { interactions of GPs and } \\
\text { PCs affect GPs } \\
\text { prescribing behaviour, } \\
\text { information from detailers } \\
\text { makes prescribing prac- } \\
\text { tices less appropriate }\end{array}$ \\
\hline
\end{tabular}




\begin{tabular}{|c|c|c|c|c|c|}
\hline 110 & 1997 & $\begin{array}{l}\text { to describe the } \\
\text { mismatch be- } \\
\text { tween GPsi } \\
\text { recorded actions } \\
\text { and opinions in } \\
\text { the management } \\
\text { of acute asthrna }\end{array}$ & $\begin{array}{l}\text { nearly all } \\
\text { GPs of in } \\
\text { the } \\
\text { Welington } \\
\text { region of } \\
\text { New } \\
\text { Zealand }\end{array}$ & $\begin{array}{l}\text { comparing } \\
\text { clinical } \\
\text { record } \\
\text { data and } \\
\text { questionna } \\
\text { ire about } \\
\text { ideal } \\
\text { manage- } \\
\text { ment }\end{array}$ & $\begin{array}{l}\text { there were "gaps" between } \\
\text { opinion and action, among } \\
\text { others: in prescribing } \\
\text { asthma medication and } \\
\text { antibiotics; the findings } \\
\text { indicate the need for } \\
\text { implementation of } \\
\text { guidelines. }\end{array}$ \\
\hline \multicolumn{6}{|c|}{ Quality in prescribing } \\
\hline 5 & 1996 & $\begin{array}{l}\text { to examine the } \\
\text { effects of a } \\
\text { financial incentive } \\
\text { scheme on } \\
\text { prescribing in non- } \\
\text { fundholding } \\
\text { general practices }\end{array}$ & $\begin{array}{l}459 \text { non- } \\
\text { fundholdi- } \\
\text { ng } \\
\text { practices } \\
\text { in former } \\
\text { Northern } \\
\text { region. } \\
\text { UK, in } \\
1993-4\end{array}$ & $\begin{array}{l}\text { observat. } \\
\text { study with } \\
\text { interventio } \\
\mathrm{n} \text { : target } \\
\text { savings for } \\
\text { each } \\
\text { group of } \\
\text { practices, } \\
\text { if achieved } \\
\text { paid a } \\
\text { portion of } \\
\text { the } \\
\text { savings }\end{array}$ & $\begin{array}{l}\text { the prescribing behaviour } \\
\text { of non-fundholding GPs } \\
\text { responded to financial } \\
\text { incentives in a similar way } \\
\text { to that of fundholding GPS; } \\
\text { the incentive scheme did } \\
\text { not seem to reduce the } \\
\text { quality of prescribing }\end{array}$ \\
\hline 78 & 1996 & $\begin{array}{l}\text { to determine the } \\
\text { prevalence of } \\
\text { potentially } \\
\text { inappropriate long } \\
\text { term prescribing in } \\
\text { general practice }\end{array}$ & $\begin{array}{l}\text { UK of } \\
\text { Britain }\end{array}$ & $\begin{array}{l}\text { literature } \\
\text { review } \\
1980-1995\end{array}$ & $\begin{array}{l}\text { evidence base supporting } \\
\text { allegations of } \\
\text { inappropriate prescribing } \\
\text { in general practice is } \\
\text { unsound; scale of problem } \\
\text { unknown: limitations with } \\
\text { selection of standard, pub- } \\
\text { lication bias, uncertainty } \\
\text { on context of prescr. deci- } \\
\text { sions; opportunities for } \\
\text { cost savings and } \\
\text { effectiveness gains } \\
\text { therefore remain unclear }\end{array}$ \\
\hline
\end{tabular}




\begin{tabular}{|c|c|c|c|c|c|}
\hline 210 & 1998 & $\begin{array}{l}\text { to describe a } \\
\text { simple method for } \\
\text { assessing the } \\
\text { quality of drug } \\
\text { prescribing }\end{array}$ & $\begin{array}{l}\text { south- } \\
\text { western } \\
\text { Stockholm } \\
\text { Sweden }\end{array}$ & $\begin{array}{l}\text { drug } \\
\text { utilization } \\
\text { analysis } \\
\text { based on } \\
\text { prescriptio } \\
\text { ns } \\
\text { purchased } \\
\text { in } 24 \mathrm{PHC} \\
\text { centres in } \\
1995\end{array}$ & $\begin{array}{l}\text { drug utilization } 90 \% \text { is an } \\
\text { inexpensive, flexible and } \\
\text { simple method for } \\
\text { assessing quality of drug } \\
\text { prescribing; number of } \\
\text { products in the DU90\% } \\
\text { segment and adherence to } \\
\text { prescription guidelines } \\
\text { may be adapted to com- } \\
\text { pare between PHC } \\
\text { centres, hospitals, regions, } \\
\text { both cross-sectional and } \\
\text { longitudinal; other criteria, } \\
\text { specific for drugs com- } \\
\text { plement general } \\
\text { indicators. }\end{array}$ \\
\hline 181 & 1998 & $\begin{array}{l}\text { to study the } \\
\text { appropriateness of } \\
\text { prescribing }\end{array}$ & $\begin{array}{l}\text { Canadian } \\
\text { physicians }\end{array}$ & $\begin{array}{l}\text { review of } \\
\text { studies on } \\
\text { prescribing } \\
\text { to } \\
\text { individuals } \\
\text { and from } \\
\text { administrat } \\
\text { ive } \\
\text { databases } \\
\text { and } \\
\text { methods to } \\
\text { improve } \\
\text { prescribing } \\
\text { behaviour }\end{array}$ & $\begin{array}{l}\text { evidence reveals a } \\
\text { significant level of } \\
\text { inappropriate prescribing: } \\
\text { two important reasons } \\
\text { seem to be GPs' level of } \\
\text { knowledge and GPs" } \\
\text { practice settings; most } \\
\text { methods tried to improve } \\
\text { prescribing behaviour are } \\
\text { unsuccessful or difficult to } \\
\text { implement in Canada; } \\
\text { alternative forms of GP } \\
\text { payment are probably } \\
\text { necessary to make } \\
\text { prescribing more } \\
\text { appropriate }\end{array}$ \\
\hline
\end{tabular}




\section{table 2.4 information (evidence based medicine, medical audit, guidelines and}

protocolls, pharmaceutical companies, pharmacists)

\begin{tabular}{|c|c|c|c|c|c|}
\hline ref. & year & objective & setting & design & results / comments \\
\hline \multicolumn{6}{|c|}{ evidence based medicine } \\
\hline 35 & 1997 & $\begin{array}{l}\text { to review what can } \\
\text { be learnt from the } \\
\text { limitations of } \\
\text { evidence based } \\
\text { medicine of } \\
\text { current best } \\
\text { evidence for the } \\
\text { way to design } \\
\text { future studies }\end{array}$ & & $\begin{array}{l}\text { a literature } \\
\text { based } \\
\text { study }\end{array}$ & $\begin{array}{l}\text { for internal validity many } \\
\text { studies performed under } \\
\text { conditions and circum- } \\
\text { stances quite different } \\
\text { from clinical practice; } \\
\text { databases and practice } \\
\text { computer networks will } \\
\text { provide sampling frames } \\
\text { for clinical research; } \\
\text { solutions closely } \\
\text { connected with clinical } \\
\text { care may not be ideal, but } \\
\text { best achievable. }\end{array}$ \\
\hline 49 & 1998 & $\begin{array}{l}\text { to state that the } \\
\text { efficacy and safety } \\
\text { of the use of } \\
\text { diuretics is } \\
\text { wrongly neglected } \\
\text { by prescribers }\end{array}$ & $\begin{array}{l}\text { US } \\
\text { recommen } \\
\text { dation by } \\
\text { the UNC VI }\end{array}$ & $\begin{array}{l}\text { theoretical } \\
\text { foundation } \\
\text { of the } \\
\text { recom- } \\
\text { mendatio- } \\
\text { ns }\end{array}$ & $\begin{array}{l}\text { despite evidence based } \\
\text { national recommenclations } \\
\text { use of diuretics has steadi- } \\
\text { ly decreased over the past } \\
15 \text { years, reasons include } \\
\text { heavy promotion of other } \\
\text { medications and mis- } \\
\text { understandings on ad- } \\
\text { verse effects and lack of } \\
\text { efficacy }\end{array}$ \\
\hline 94 & 1998 & $\begin{array}{l}\text { study the effect of } \\
\text { several } \\
\text { controversial } \\
\text { reports about } \\
\text { calcium channell } \\
\text { blocking agents in } \\
\text { professional and } \\
\text { lay media }\end{array}$ & $\begin{array}{l}\text { all } \\
\text { physicians } \\
(4403) \text { in } \\
\text { British } \\
\text { Columbia }\end{array}$ & $\begin{array}{l}\text { a natural } \\
\text { experiment }\end{array}$ & $\begin{array}{l}\text { declining proportion of pa- } \\
\text { tients receiving CCB as } \\
\text { first-line therapy; adverse } \\
\text { news nor guidelines no } \\
\text { direct effect; gradual } \\
\text { change to thiazide with the } \\
\text { accumulation of reports }\end{array}$ \\
\hline 102 & 1993 & $\begin{array}{l}\text { to determine the } \\
\text { use of new drugs } \\
\text { (ACE-inhibitors, } \\
\text { broad spectrum } \\
\text { antibiotics and } \mathrm{H} 2 \\
\text { receptor } \\
\text { antagonists) in } \\
1988-91\end{array}$ & $\begin{array}{l}\text { all general } \\
\text { practices } \\
\text { in Northern } \\
\text { Ireland }\end{array}$ & $\begin{array}{l}\text { examinatio } \\
\text { n of pre- } \\
\text { script and } \\
\text { calculation } \\
\text { of DDD / } \\
\text { month }\end{array}$ & $\begin{array}{l}\text { study suggests that } \\
\text { profession did not institute } \\
\text { effective checks to ensure } \\
\text { that legitimate promotion } \\
\text { of new products does not } \\
\text { lead to inappropriate and } \\
\text { wasteful use }\end{array}$ \\
\hline
\end{tabular}




\begin{tabular}{|c|c|c|c|c|c|}
\hline 157 & 2000 & $\begin{array}{l}\text { to survey two } \\
\text { matrix-methods } \\
\text { for drug choice: } \\
\text { SOJA and Infor } \\
\text { Matrix }\end{array}$ & $\begin{array}{l}\text { the } \\
\text { Netherland } \\
\text { s }\end{array}$ & $\begin{array}{l}\text { description } \\
\text { and survey }\end{array}$ & $\begin{array}{l}\text { methods base their choic- } \\
\text { es on relevant and } \\
\text { rational, mutually } \\
\text { compensatory criteria, } \\
\text { agreed and weighed in ad- } \\
\text { vance, exciuding emo- } \\
\text { tional and/or unaware } \\
\text { interests; on these criteria } \\
\text { therapeutic value of } \\
\text { interchangeable drugs is } \\
\text { assessed; methods can be } \\
\text { useful aids for PTAM and } \\
\text { formulary committees, } \\
\text { insight in the complexity of } \\
\text { drug choice. }\end{array}$ \\
\hline \multicolumn{6}{|c|}{ medical audit } \\
\hline 1 & 1992 & $\begin{array}{l}\text { to estimate the } \\
\text { effects of medical } \\
\text { audit, particularly } \\
\text { setting clinical } \\
\text { standards, on } \\
\text { GPs' clinical } \\
\text { behaviour }\end{array}$ & $\begin{array}{l}84 \text { GP } \\
\text { trainers in } \\
64 \\
\text { practices } \\
\text { in the } \\
\text { north of } \\
\text { England }\end{array}$ & $\begin{array}{l}\text { before and } \\
\text { after } \\
\text { different } \\
\text { interventio } \\
\text { ns, } \\
\text { replicated } \\
\text { Latin } \\
\text { square }\end{array}$ & $\begin{array}{l}\text { changes were consistent } \\
\text { with the intervention by } \\
\text { introducing standards; } \\
\text { setting clinical standards } \\
\text { improved prescribing and } \\
\text { follow-up }\end{array}$ \\
\hline 3 & 1997 & $\begin{array}{l}\text { to bring } \\
\text { computerized } \\
\text { claims together } \\
\text { with explicit } \\
\text { criteria for } \\
\text { appropriate } \\
\text { prescribing in } \\
\text { order to assess } \\
\text { (in)appropriate- } \\
\text { ness and } \\
\text { associate it with } \\
\text { defined physician } \\
\text { characteristics }\end{array}$ & $\begin{array}{l}\text { a universal } \\
\text { and } \\
\text { comprehe } \\
\text { nsive drug } \\
\text { benefit } \\
\text { plan for } \\
\text { the elderly }\end{array}$ & $\begin{array}{l}\text { analysis of } \\
\text { computeriz } \\
\text { ed claims }\end{array}$ & $\begin{array}{l}\text { rate of potentially } \\
\text { inappropriate drug } \\
\text { receiving by elderly } \\
\text { patients } 38 \% \text { for } \\
\text { antidepressants, } 19 \% \text { for } \\
\text { oral hypoglycemics. } 18 \% \\
\text { for anti-inflamm. drugs; } \\
\text { older GPs and GPs with- } \\
\text { out speciality certification } \\
\text { more likely to prescribe } \\
\text { inappropriate; drug claims } \\
\text { databases provide over- } \\
\text { view of prescribing } \\
\text { problems at a population } \\
\text { level and reveal GPs } \\
\text { characteristics; linking to } \\
\text { more clinical details is } \\
\text { necessary for a more } \\
\text { definitive measure of } \\
\text { appropriateness. }\end{array}$ \\
\hline
\end{tabular}




\begin{tabular}{|c|c|c|c|c|c|}
\hline 12 & 1995 & $\begin{array}{l}\text { to test wether an } \\
\text { audit facilitator } \\
\text { could alter the } \\
\text { pattern of } \\
\text { diagnosis and } \\
\text { treatment of } \\
\text { childhood asthma }\end{array}$ & $\begin{array}{l}12 \text { general } \\
\text { practices } \\
\text { in Tayside, } \\
\text { UK }\end{array}$ & $\begin{array}{l}\text { randornise } \\
d \text { stratified } \\
\text { controlled } \\
\text { trial }\end{array}$ & $\begin{array}{l}\text { intervention-group more } \\
\text { practice initiated con- } \\
\text { sultations, new diagnoses } \\
\text { of asthma, and past } \\
\text { diagnoses reaffirmed; } \\
\text { hospital inpatient days fell } \\
\text { in inte-rvention-group and } \\
\text { rose in control-group; audit } \\
\text { facilitator can favourably } \\
\text { influence diagnosis and } \\
\text { treatment of childhood } \\
\text { asthma in general practice }\end{array}$ \\
\hline 23 & 1990 & $\begin{array}{l}\text { to describe a } \\
\text { special format for } \\
\text { individualised } \\
\text { feedback }\end{array}$ & $\begin{array}{l}\text { the Nelson } \\
\text { region in } \\
\text { New } \\
\text { Zealand }\end{array}$ & $\begin{array}{l}\text { descriptive } \\
\text { paper }\end{array}$ & $\begin{array}{l}\text { format developed for GPS } \\
\text { participating in the Nelson } \\
\text { prescribing project; } \\
\text { successfully in conjunction } \\
\text { with a preferred medicines } \\
\text { list; it provides unbiased, } \\
\text { reliable information }\end{array}$ \\
\hline 24 & 1990 & $\begin{array}{l}\text { to develop a } \\
\text { model for cost } \\
\text { effective } \\
\text { prescribing in } \\
\text { general practice }\end{array}$ & $\begin{array}{l}\text { a pilot } \\
\text { audit of } \\
\text { regional } \\
\text { prescribing } \\
\text { patterns }\end{array}$ & $\begin{array}{l}\text { descriptive } \\
\text { paper } \\
\text { about a } \\
\text { pilot study }\end{array}$ & $\begin{array}{l}\text { marked variation between } \\
\text { GPs in medicines choice, } \\
\text { cost and number of } \\
\text { scripts; benzodiazepine } \\
\text { prescribing not in line with } \\
\text { current guidelines and was } \\
\text { high, audited prescription } \\
\text { data allows definitions of } \\
\text { educational and pricing } \\
\text { strategies }\end{array}$ \\
\hline 25 & 1985 & $\begin{array}{l}\text { to determine } \\
\text { prescription } \\
\text { activity of doctors } \\
\text { during a period of } \\
\text { self-audit }\end{array}$ & UK & $\begin{array}{l}\text { prescriptio } \\
n \text { forms } \\
\text { obtained } \\
\text { from } 34 \\
\text { GPs } \\
\text { during } 2 \\
\text { control } \\
\text { weeks and } \\
1 \text { month of } \\
\text { observatio } \\
n \text { period }\end{array}$ & $\begin{array}{l}\text { in last week of observation } \\
\text { period the number of } \\
\text { prescriptions was reduced } \\
\text { in one group (control } \\
\text { weeks after observation), } \\
\text { not in second group } \\
\text { (observation after control } \\
\text { weeks); proportion of } \\
\text { drugs in the various } \\
\text { categories was consistent ; } \\
\text { self-audit does not appear } \\
\text { to influence the underlying } \\
\text { activity audited. }\end{array}$ \\
\hline
\end{tabular}




\begin{tabular}{|c|c|c|c|c|c|}
\hline 26 & 1985 & $\begin{array}{l}\text { to determine to } \\
\text { which extent GPS } \\
\text { would participate } \\
\text { in quality } \\
\text { assessment } \\
\text { activities based on } \\
\text { objective evidence } \\
\text { of performance } \\
\text { and the personal } \\
\text { and professional } \\
\text { characteristics of } \\
\text { interested doctors }\end{array}$ & $\begin{array}{l}\text { UK, } \\
\text { Leicester- } \\
\text { shire and } \\
\text { Lincoln- } \\
\text { shire }\end{array}$ & $\begin{array}{l}508 \text { replies } \\
\text { on } 669 \\
\text { questionna } \\
\text { ires }\end{array}$ & $\begin{array}{l}\text { most of the responcents } \\
(61 \%) \text { were interested in } \\
\text { audit activities }\end{array}$ \\
\hline 50 & 1996 & $\begin{array}{l}\text { to demonstrate } \\
\text { wether } \\
\text { standardization of } \\
\text { practice } \\
\text { populations by } \\
\text { age and sex } \\
\text { changes the } \\
\text { internai } \\
\text { prescription } \\
\text { ranking order of a } \\
\text { group of practices }\end{array}$ & $\begin{array}{l}41 \text { GPs in } \\
35 \\
\text { practices } \\
\text { in } \\
\text { Randers, } \\
\text { Aarhus } \\
\text { county, } \\
\text { Denmark }\end{array}$ & $\begin{array}{l}\text { data from } \\
\text { a county- } \\
\text { based } \\
\text { database } \\
\text { on } \\
\text { prescribing } \\
\text { of cardio- } \\
\text { vascular } \\
\text { drugs in a } \\
\text { group of } \\
\text { practices }\end{array}$ & $\begin{array}{l}\text { change from crude to stan- } \\
\text { dardized utilization index } \\
\text { glave an entirely new } \\
\text { ranking order of practices; } \\
\text { the slope between the } \\
\text { highest and lowest ranked } \\
\text { practice did not diminish } \\
\text { after standardization; prior } \\
\text { age and sex stan- } \\
\text { dardization is } \\
\text { recommended when } \\
\text { comparing peer prescr. } \\
\text { patterns }\end{array}$ \\
\hline 81 & 1994 & $\begin{array}{l}\text { to survey the } \\
\text { information } \\
\text { sources used by } \\
\text { GPs, with a } \\
\text { special interest for } \\
\text { the short drug } \\
\text { letters provided by } \\
\text { hospital } \\
\text { pharmacists and } \\
\text { community phar- } \\
\text { macists }\end{array}$ & $\begin{array}{l}\text { Betuwe } \\
\text { region in } \\
\text { the middle } \\
\text { of The } \\
\text { Neth- } \\
\text { erlands }\end{array}$ & $\begin{array}{l}\text { question- } \\
\text { naires }\end{array}$ & $\begin{array}{l}\text { drug letter was the most } \\
\text { frequently used } \\
\text { information source in the } \\
\text { decision stage, especially } \\
\text { section about advantages } \\
\text { and disadvantages of new } \\
\text { drugs; at introduction } \\
\text { stage the MR seems most } \\
\text { frequently used source; at } \\
\text { information stage it is the } \\
\text { Dutch Drug Bulletin; in } \\
\text { only } 20 \% \text { of PTAM-groups } \\
\text { attention is paid to the } \\
\text { drug letter }\end{array}$ \\
\hline
\end{tabular}




\begin{tabular}{|l|l|l|l|l|l|}
\hline 106 & 1999 & $\begin{array}{l}\text { using prescription } \\
\text { data from } \\
\text { pharmacy-com- } \\
\text { puters in pharma- } \\
\text { co therapeutic } \\
\text { audit meetings }\end{array}$ & $\begin{array}{l}\text { Dutch } \\
\text { phar- } \\
\text { macies }\end{array}$ & $\begin{array}{l}\text { discussion, } \\
\text { and } \\
\text { PTAM's }\end{array}$ & $\begin{array}{l}\text { for several aims (quality of } \\
\text { of } \\
\text { drug choice, volume, } \\
\text { measures } \\
\text { and } \\
\text { suggestion } \\
\text { costs) of PTAMs, } \\
\text { prescription data provide } \\
\text { useful information if data } \\
\text { sufficiently cover GPs } \\
\text { patient population and } \\
\text { repeat prescriptions are } \\
\text { recognised. }\end{array}$ \\
\hline
\end{tabular}




\begin{tabular}{|c|c|c|c|c|c|}
\hline \multicolumn{6}{|c|}{ guidelines / protocols } \\
\hline 16 & 1999 & $\begin{array}{l}\text { insight into the } \\
\text { reasons for actual } \\
\text { prescribing of } \\
\text { antibiotics for } \\
\text { acute otitis media }\end{array}$ & $\begin{array}{l}70 \\
\text { antibiotic } \\
\text { prescriptio } \\
\text { ns by } 22 \\
\text { Dutch GPs } \\
\text { were eval- } \\
\text { uated }\end{array}$ & $\begin{array}{l}\text { discussion } \\
\text { in } \\
\text { stimulated } \\
\text { recall } \\
\text { interviews }\end{array}$ & $\begin{array}{l}77 \% \text { of the prescriptions } \\
\text { did not follow the NHG- } \\
\text { guidelines; appropriate } \\
\text { use of antibiotics might not } \\
\text { be reached by focusing } \\
\text { only on the efficacy of } \\
\text { these drugs }\end{array}$ \\
\hline 43 & 1999 & $\begin{array}{l}\text { to describe } \\
\text { prescriptive } \\
\text { behaviour among } \\
\text { GPs in choosing } \\
\text { an empirical } \\
\text { antibiotic regimen } \\
\text { for LRTIs and to } \\
\text { begin an } \\
\text { educational } \\
\text { process }\end{array}$ & $\begin{array}{l}76 \text { GPs in } \\
\text { Sicily. } \\
\text { september } \\
1995 / \text { may } \\
1996\end{array}$ & $\begin{array}{l}\text { question- } \\
\text { naires for } \\
\text { each } \\
\text { therapeutic } \\
\text { interventio } \\
\text { n which } \\
\text { ended with } \\
\text { an } \\
\text { antibiotic }\end{array}$ & $\begin{array}{l}\text { the marked variation } \\
\text { reflects lack of availability } \\
\text { or knowledge of any local } \\
\text { or national guidelines; }\end{array}$ \\
\hline 45 & 1999 & $\begin{array}{l}\text { to survey primary } \\
\text { care physicians' } \\
\text { antihypertensive } \\
\text { prescribing } \\
\text { practices and their } \\
\text { treatment } \\
\text { recommendations } \\
\text { for patients with } \\
\text { comorbidities }\end{array}$ & $\begin{array}{l}\text { US of } \\
\text { America } \\
\text { over } 18 \\
\text { manths }\end{array}$ & $\begin{array}{l}\text { a direct } \\
\text { mail } \\
\text { survey } \\
\text { sent to a } \\
\text { national } \\
\text { random } \\
\text { sample of } \\
\text { doctors }\end{array}$ & $\begin{array}{l}\text { ACE-inhibitors increased } \\
\text { in patients with congestive } \\
\text { heart failure and diabetes; } \\
\text { beta-blockers increased } \\
\text { for MI patients; GPS did } \\
\text { not follow JNC recomm. } \\
\text { for black patients, older } \\
\text { patients or with mild renal } \\
\text { failure; more prescribing } \\
\text { was in line with JNC } \\
\text { recommendations after } 19 \\
\text { months; younger } \\
\text { physicians prescribe more } \\
\text { consistent with the } \\
\text { guidelines }\end{array}$ \\
\hline
\end{tabular}




\begin{tabular}{|c|c|c|c|c|c|}
\hline 70 & 1990 & $\begin{array}{l}\text { to see wether } \\
\text { changes in } \\
\text { prescribing of oral } \\
\text { antibacterials in } \\
\text { Northern Ireland } \\
\text { show the need for } \\
\text { a community } \\
\text { antibiotics policy }\end{array}$ & $\begin{array}{l}\text { audit of } \\
\text { anti- } \\
\text { infective } \\
\text { prescribing } \\
\text { in general } \\
\text { practice in } \\
\text { Northern } \\
\text { Ireland } \\
\text { over } 5 \\
\text { years }\end{array}$ & $\begin{array}{l}\text { analysis of } \\
\text { prescribing } \\
\text { totals for } \\
\text { several } \\
\text { oral } \\
\text { antiblotics } \\
\text { obtained } \\
\text { retrospecti } \\
\text { vely from } \\
\text { the } \\
\text { prescriptio } \\
\text { n pricing } \\
\text { bureau for } \\
\text { the years } \\
1983-7\end{array}$ & $\begin{array}{l}\text { there was a gradual } \\
\text { decrease in the rellative } \\
\text { use of "common" agents } \\
\text { from } 82 \% \text { to } 77 \% \text {; with a } \\
\text { complementary increase in } \\
\text { the use of "occasional" } \\
\text { agents from } 5 \% \text { to } 10 \% \text {; } \\
\text { reasonably conservative } \\
\text { prescribing was found and } \\
\text { the trend towards } \\
\text { increased use of } \\
\text { occasional agents could } \\
\text { be addressed by the use } \\
\text { of a prescribing formulary }\end{array}$ \\
\hline 90 & 1999 & $\begin{array}{l}\text { voluntary changes } \\
\text { in antiemetic } \\
\text { prescribing } \\
\text { practice }\end{array}$ & $\begin{array}{l}\text { postanes- } \\
\text { thesia care } \\
\text { in acad. } \\
\text { medical } \\
\text { centre }\end{array}$ & $\begin{array}{l}\text { prospectiv } \\
e_{1} \\
\text { observatio } \\
\text { nal } \\
\text { randomize } \\
\text { d study }\end{array}$ & $\begin{array}{l}\text { protocols were followed } \\
\text { voluntarily }\end{array}$ \\
\hline 93 & 1995 & $\begin{array}{l}\text { to study the effect } \\
\text { of "academic } \\
\text { group detailing" on } \\
\text { prescribing lipid- } \\
\text { lowering drugs }\end{array}$ & $\begin{array}{l}134 \\
\text { community } \\
\text { health } \\
\text { centres in } \\
\text { Swedish } \\
\text { primary } \\
\text { care }\end{array}$ & $\begin{array}{l}\text { interventio } \\
\text { n-vs } \\
\text { control- } \\
\text { group }\end{array}$ & $\begin{array}{l}\text { guidelines for the } \\
\text { management of } \\
\text { hyperlipidaemia increased } \\
\text { the prescription of lipid- } \\
\text { lowering drugs }\end{array}$ \\
\hline 110 & 1997 & $\begin{array}{l}\text { to describe the } \\
\text { mismatch be- } \\
\text { tween GPs' } \\
\text { recorded actions } \\
\text { and opinions in } \\
\text { the management } \\
\text { of acute asthma }\end{array}$ & $\begin{array}{l}\text { nearly all } \\
\text { GPs of in } \\
\text { the } \\
\text { Wellington } \\
\text { region of } \\
\text { New } \\
\text { Zealand }\end{array}$ & $\begin{array}{l}\text { comparing } \\
\text { clinical } \\
\text { records } \\
\text { and quest- } \\
\text { ionnaire on } \\
\text { ideal } \\
\text { managem } \\
\text { ent }\end{array}$ & $\begin{array}{l}\text { there were "gaps" between } \\
\text { opinion and action; the } \\
\text { findings indicate the need } \\
\text { for implementation of } \\
\text { guidelines. }\end{array}$ \\
\hline 112 & 1996 & $\begin{array}{l}\text { evaluate the } \\
\text { impact of a } \\
\text { protocol-driven } \\
\text { antihypertensive } \\
\text { therapy on } \\
\text { outcomes }\end{array}$ & $\begin{array}{l}\text { New York } \\
\text { City, three } \\
\text { periods: } \\
1986-87 \text { vs } \\
1990-91 \text { vs } \\
1992\end{array}$ & $\begin{array}{l}\text { viz. } 231, \\
213 \text { and } \\
106 \\
\text { presumabl } \\
y \\
\text { untreated } \\
\text { patients }\end{array}$ & $\begin{array}{l}\text { first prescr. changed from } \\
85-90 \% \text { diuretics or beta- } \\
\text { bl. to } 90 \% \text { calcium ch. bl. } \\
\text { or ACE inh. and then to an } \\
\text { even distribution of drugs } \\
\text { in period } 11 \text {, little discern- } \\
\text { able impact on short term } \\
\text { patient outcomes; blood } \\
\text { pressure response similar } \\
\text { over the three periods }\end{array}$ \\
\hline
\end{tabular}




\begin{tabular}{|c|c|c|c|c|c|}
\hline 39 & 1987 & $\begin{array}{l}\text { to give a stated } \\
\text { opinion about the } \\
\text { spending of drug } \\
\text { companies on } \\
\text { promoting their } \\
\text { products }\end{array}$ & Canada & $\begin{array}{l}\text { opinion } \\
\text { forming } \\
\text { paper }\end{array}$ & $\begin{array}{l}\text { although industry adopted } \\
\text { a voluntary code of } \\
\text { advertising practice, there } \\
\text { is still excess of } \\
\text { pharmaceutical promotion } \\
\text { adding to the cost of } \\
\text { drugs, leading to poor } \\
\text { prescribing and significant } \\
\text { adverse health effects for } \\
\text { patients; reforms are } \\
\text { possible but unlikely to } \\
\text { come from med. } \\
\text { profiession or government }\end{array}$ \\
\hline 49 & 1998 & $\begin{array}{l}\text { to state that the } \\
\text { efficacy and safety } \\
\text { of the use of } \\
\text { diuretics is } \\
\text { wrongly neglected } \\
\text { by prescribers }\end{array}$ & $\begin{array}{l}\text { US } \\
\text { recommen } \\
\text { dation by } \\
\text { the JNC VI }\end{array}$ & $\begin{array}{l}\text { theoretical } \\
\text { foundation } \\
\text { of the } \\
\text { recommen } \\
\text { dations }\end{array}$ & $\begin{array}{l}\text { despite evidence based } \\
\text { national recommendations } \\
\text { the use of diuretics has } \\
\text { steadily decreased over } \\
\text { the past } 15 \text { years, reasons } \\
\text { include the heavy } \\
\text { promotion of other } \\
\text { medications and } \\
\text { misunderstandings about } \\
\text { adverse effects and lack of } \\
\text { efficacy }\end{array}$ \\
\hline 79 & 1995 & $\begin{array}{l}\text { to examine the } \\
\text { type and number } \\
\text { of interactions of } \\
\text { doctors with sales } \\
\text { representatives of } \\
\text { phamaceutical } \\
\text { companies and } \\
\text { the attitudes of } \\
\text { physicians in } \\
\text { training towards } \\
\text { these interactions }\end{array}$ & $\begin{array}{l}7 \text { teaching } \\
\text { hospitals } \\
\text { affiliated } \\
\text { with the } \\
\text { Departmen } \\
\text { t of } \\
\text { Psychiatry, } \\
\text { University } \\
\text { of Toronto; } \\
10-1993 \text { till } \\
2-1994\end{array}$ & $\begin{array}{l}\text { self report } \\
\text { questionna } \\
\text { ire }\end{array}$ & $\begin{array}{l}\text { interactions between MRs } \\
\text { and doctors were com- } \\
\text { mon; many disavowed the } \\
\text { potential of interactions to } \\
\text { influence prescribing; } \\
\text { physicians in training per- } \\
\text { ceived little educational } \\
\text { value; } 71 \% \text { disagreed with } \\
\text { banning MRs from making } \\
\text { presentations; fewer than } \\
\text { half would maintain the } \\
\text { same degree of contact } \\
\text { without receiving } \\
\text { promotional gifts; the more } \\
\text { gifts a physician in training } \\
\text { received, less he belleved } \\
\text { that discussions with MRs } \\
\text { did not affect prescribing }\end{array}$ \\
\hline
\end{tabular}




\begin{tabular}{|c|c|c|c|c|c|}
\hline 80 & 1995 & $\begin{array}{l}\text { to learn more } \\
\text { about patients } \\
\text { awareness of and } \\
\text { attitude about gifts } \\
\text { to GPs from } \\
\text { pharmaceutical } \\
\text { companies }\end{array}$ & $\begin{array}{l}\text { the waiting } \\
\text { rooms of } \\
\text { two family } \\
\text { practices } \\
\text { in central } \\
\text { Missouri }\end{array}$ & $\begin{array}{l}\text { self- } \\
\text { administer } \\
\text { ed } \\
\text { questionna } \\
\text { ire }\end{array}$ & $\begin{array}{l}\text { respondents distinguished } \\
\text { between gifts, high appro- } \\
\text { val rates for trivial gifts or } \\
\text { with potential value to } \\
\text { patient care; disapproval } \\
\text { for gifts withmonetary } \\
\text { value or no benefit for } \\
\text { patients; opinions related } \\
\text { to perceptions of gift } \\
\text { effects on prescribing and } \\
\text { costs }\end{array}$ \\
\hline 81 & 1994 & $\begin{array}{l}\text { to survey the } \\
\text { information } \\
\text { sources used by } \\
\text { GPs, with a } \\
\text { special interest for } \\
\text { the short drug } \\
\text { letters provided by } \\
\text { hospital } \\
\text { pharmacists and } \\
\text { community } \\
\text { pharmacists }\end{array}$ & $\begin{array}{l}\text { Betuwe } \\
\text { region in } \\
\text { the middle } \\
\text { of The } \\
\text { Neth- } \\
\text { eriands }\end{array}$ & $\begin{array}{l}\text { questionna } \\
\text { ires }\end{array}$ & $\begin{array}{l}\text { the drug letter was the } \\
\text { most frequently used } \\
\text { information source in the } \\
\text { decision stage; especially } \\
\text { the section about } \\
\text { advantages and } \\
\text { disadvantages of new } \\
\text { drugs compared to other } \\
\text { drugs; at the introductions } \\
\text { stage the MR seems to be } \\
\text { the most frequently used } \\
\text { source; at the information } \\
\text { stage it is the Dutch Drug } \\
\text { Bulletin; in only } 20 \% \text { of the } \\
\text { regional PTAM-groups } \\
\text { attention is paid to the } \\
\text { drug letter }\end{array}$ \\
\hline 83 & 1998 & $\begin{array}{l}\text { to compare } \\
\text { physicians" and } \\
\text { their patients' } \\
\text { attitudes toward } \\
\text { pharmaceutical } \\
\text { gifts }\end{array}$ & $\begin{array}{l}\text { two tertiary } \\
\text { medical } \\
\text { centres: } \\
\text { one } \\
\text { military } \\
\text { and one } \\
\text { civilian }\end{array}$ & $\begin{array}{l}\text { survey of } \\
\text { physicians } \\
\text { and their } \\
\text { patients }\end{array}$ & $\begin{array}{l}10 \text { pharmaceutical gifts } \\
\text { were rated whether or not } \\
\text { appropriate or likely to } \\
\text { influence prescription; } \\
\text { patients feel } \\
\text { pharmaceutical gifts less } \\
\text { appropriate and more } \\
\text { influential then GPs }\end{array}$ \\
\hline
\end{tabular}




\begin{tabular}{|c|c|c|c|c|c|}
\hline 84 & 1997 & $\begin{array}{l}\text { to consider the } \\
\text { relationship } \\
\text { between MRs and } \\
\text { physicians in the } \\
\text { framework argued } \\
\text { for by Engelhardt }\end{array}$ & & $\begin{array}{l}\text { philosophi } \\
\text { cal } \\
\text { considerati } \\
\text { on }\end{array}$ & $\begin{array}{l}\text { four major criticisms on } \\
\text { MR-physician relation- } \\
\text { ships: influence, patients } \\
\text { pay, vioiation of ethical } \\
\text { principles, erosion of } \\
\text { patient-physician relations; } \\
\text { each shown unpersuasive } \\
\text { under Engelhardtian } \\
\text { philosophy; as long as the } \\
\text { principles of permission } \\
\text { and informed consent } \\
\text { were obtained without } \\
\text { coercion, the interaction } \\
\text { would be construed to be } \\
\text { morally permissible }\end{array}$ \\
\hline 85 & 1997 & $\begin{array}{l}\text { to survey physi- } \\
\text { cians' attitudes } \\
\text { surrounding the } \\
\text { "gift relationship" } \\
\text { between } \\
\text { pharmaceutical } \\
\text { companies and } \\
\text { physicians }\end{array}$ & $\begin{array}{l}\text { West } \\
\text { Virginia, } \\
283 \\
\text { responses } \\
\text { on } 1000 \\
\text { mailed } \\
\text { surveys }\end{array}$ & survey & $\begin{array}{l}\text { physicians slightly agreed } \\
\text { that PCs give gifts to } \\
\text { influence prescribing and } \\
\text { that PCs' sponsoring of } \\
\text { CME-programmes are } \\
\text { promotional gimmicks: it } \\
\text { may be inappropriate to } \\
\text { accept gifts from PCs; } \\
\text { moderately disagreed that } \\
\text { gifts express professional } \\
\text { recognition; strongly } \\
\text { disagree that their } \\
\text { behaviour could be influ- } \\
\text { enced by gifts; GPs slightly } \\
\text { averse to having their } \\
\text { relationship made public; } \\
\text { correlation analysis show- } \\
\text { ed greater likeliness of } \\
\text { gifts to GPs the larger the } \\
\text { nr. of pat. patients/day } \\
\text { and prescr./ day; the latter } \\
\text { GPs were more likely to } \\
\text { condone the practice of } \\
\text { gifts }\end{array}$ \\
\hline
\end{tabular}




\begin{tabular}{|c|c|c|c|c|c|}
\hline 86 & 1996 & $\begin{array}{l}\text { to evaluate the } \\
\text { influence of GPs } \\
\text { attifudes toward } \\
\text { and use of } \\
\text { information } \\
\text { provided by MRs } \\
\text { on prescribing } \\
\text { costs in } \\
\text { ambulatory } \\
\text { practice }\end{array}$ & $\begin{array}{l}\text { Kentucky } \\
\text { physicians } \\
\text { practising } \\
\text { primary } \\
\text { care adult } \\
\text { medicine } \\
(n=1603)\end{array}$ & $\begin{array}{l}\text { questionna } \\
\text { ires }\end{array}$ & $\begin{array}{l}\text { frequency of use of } \\
\text { information by MRs and } \\
\text { group practice setting } \\
\text { were significant, } \\
\text { independent positive } \\
\text { predictors of cost in the } \\
\text { multi variable regression } \\
\text { model; non-academic and } \\
\text { non-hospital setting } \\
\text { associated with increased } \\
\text { GP's prescribing costs }\end{array}$ \\
\hline 87 & 1996 & $\begin{array}{l}\text { to evaluate the } \\
\text { literature about the } \\
\text { relationship } \\
\text { between MRs and } \\
\text { physicians }\end{array}$ & & $\begin{array}{l}\text { philosophi } \\
\text { cal survey }\end{array}$ & $\begin{array}{l}\text { MR-physician relationship } \\
\text { may put patient-doctor } \\
\text { relationship in jeopardy; } \\
\text { pragmatically this woulld } \\
\text { constitute enough warrant } \\
\text { to shun such relationships; } \\
\text { no research supports this } \\
\text { contention; research leav- } \\
\text { es one ambivalent at best }\end{array}$ \\
\hline 98 & 1993 & $\begin{array}{l}\text { to review the } \\
\text { pattern of } \\
\text { prescribing } \\
\text { medicines in the } \\
\text { UK and compare it } \\
\text { with that in other } \\
\text { European markets }\end{array}$ & $\begin{array}{l}\text { UK and } \\
\text { Europe }\end{array}$ & review & $\begin{array}{l}\text { British doctors prescribe } \\
\text { fewer items, less products } \\
\text { containing a NCE and } \\
\text { progressively from a } \\
\text { smaller number of active } \\
\text { substances for greater } \\
\text { proportion of prescriptions; } \\
\text { as a result pharmaceutical } \\
\text { industry more dependent } \\
\text { on sales of older products } \\
\text { and the ability to fund } \\
\text { investment in research into } \\
\text { yet unconquered diseases } \\
\text { is reduced against the } \\
\text { interests of both patients } \\
\text { and the British economy. }\end{array}$ \\
\hline 108 & 1993 & $\begin{array}{l}\text { to determine the } \\
\text { effect of three } \\
\text { types of } \\
\text { interactions } \\
\text { between GPs and } \\
\text { pharmaceutical } \\
\text { companies }\end{array}$ & $\begin{array}{l}2227 \\
\text { papers } \\
\text { reviewed } \\
\text { within } \\
\text { criteria: } 36 \\
\text { studies } \\
\text { matched }\end{array}$ & $\begin{array}{l}\text { literature } \\
\text { search } \\
1978 \text { - } \\
1993\end{array}$ & $\begin{array}{l}\text { GPs do not have a high } \\
\text { opinion about company- } \\
\text { sponsored CME and they } \\
\text { may have a commercial } \\
\text { bias; GPs are affected by } \\
\text { their interactions with PCs }\end{array}$ \\
\hline
\end{tabular}




\begin{tabular}{|c|c|c|c|c|c|}
\hline \multicolumn{6}{|c|}{ pharmacists } \\
\hline 11 & 1995 & $\begin{array}{l}\text { to identify patients } \\
\text { in the practice with } \\
\text { inappropriate } \\
\text { medication }\end{array}$ & $\begin{array}{l}\text { GPs' } \\
\text { practice } \\
\text { administrat } \\
\text { ions }\end{array}$ & $\begin{array}{l}7 \text { GPs } \\
\text { used } \\
\text { various } \\
\text { methods }\end{array}$ & $\begin{array}{l}25 \text { different drugs for } 40 \\
\text { patients identified } \\
\text { inappropriate; almost half } \\
\text { the patients might consider } \\
\text { chan-ging their } \\
\text { medication } \text { community } \text { pharmacists could help in } \\
\text { reviewing long-term } \\
\text { medication }\end{array}$ \\
\hline 30 & 1990 & $\begin{array}{l}\text { to explore to which } \\
\text { extent the } \\
\text { inclusion of } \\
\text { pharmacies in } \\
\text { health care } \\
\text { centres has } \\
\text { provided } \\
\text { opportunities for } \\
\text { GPs to become } \\
\text { better acquainted } \\
\text { with pharmacists }\end{array}$ & $\begin{array}{l}13 \text { GPs } \\
\text { and } 10 \\
\text { pharmacist } \\
\mathrm{s} \text { in } 10 \\
\text { health care } \\
\text { centres in } \\
\text { England; } \\
\text { controls } 9 \\
\text { GPs and } \\
10 \text { pharm. }\end{array}$ & $\begin{array}{l}\text { a } \\
\text { qualitative } \\
\text { study } \\
\text { based on } \\
\text { interviews }\end{array}$ & $\begin{array}{l}\text { GPS attitudes towards } \\
\text { health centre pharmacists } \\
\text { differed imarkedly form the } \\
\text { attitudes of calleagues } \\
\text { working in relative isolation } \\
\text { from pharmacists; it } \\
\text { appears that GPs working } \\
\text { closely with the pharmacist } \\
\text { develop a collaborative } \\
\text { approach to health care. }\end{array}$ \\
\hline 31 & 1988 & $\begin{array}{l}\text { to determine } \\
\text { family practice } \\
\text { physicians' } \\
\text { perceptions of the } \\
\text { usefulness and } \\
\text { clinical outcome of } \\
\text { drug therapy } \\
\text { recommendations } \\
\text { made by clinical } \\
\text { pharmacists in a } \\
\text { family medicine } \\
\text { clinic }\end{array}$ & $\begin{array}{l}\text { US of } \\
\text { America }\end{array}$ & $\begin{array}{l}\text { questionna } \\
\text { ires, self } \\
\text { reporting }\end{array}$ & $\begin{array}{l}\text { GPs in a family medicine } \\
\text { residency training program } \\
\text { had positive perceptions of } \\
\text { the usefulness of drug } \\
\text { therapy recommendations } \\
\text { made by clinical } \\
\text { pharmacists; a majority of } \\
\text { the physicians believed } \\
\text { that the recommendations } \\
\text { had a positive effect on } \\
\text { patients' clinical status }\end{array}$ \\
\hline 61 & 1994 & $\begin{array}{l}\text { to describe the } \\
\text { development and } \\
\text { implementation of } \\
\text { a list of recom- } \\
\text { mended drugs }\end{array}$ & $\begin{array}{l}125 \text { GPs at } \\
27 \text { health } \\
\text { centres in } \\
\text { the south } \\
\text { west } \\
\text { region of } \\
\text { Stockholm, } \\
\text { Sweden }\end{array}$ & & $\begin{array}{l}\text { GPs started a process } \\
\text { towards rational } \\
\text { prescribing with the help of } \\
\text { local pharmacists } \\
\text { providing prescribing data; } \\
\text { a list of } 167 \text { recommended } \\
\text { drugs was developed; cost } \\
\text { cautiousness seemed to } \\
\text { increase, volume per } \\
\text { prescription decreased, } \\
\text { and costs were } 20 \% \text { below } \\
\text { the national prescribing } \\
\text { pattern }\end{array}$ \\
\hline
\end{tabular}




\begin{tabular}{|c|c|c|c|c|c|}
\hline 81 & 1994 & $\begin{array}{l}\text { to survey the } \\
\text { information } \\
\text { sources used by } \\
\text { GPs, with a } \\
\text { special interest for } \\
\text { the short drug } \\
\text { letters provided by } \\
\text { hospilal } \\
\text { pharmacists and } \\
\text { community phar- } \\
\text { macists }\end{array}$ & $\begin{array}{l}\text { Betuwe } \\
\text { region in } \\
\text { the middle } \\
\text { of The } \\
\text { Neth- } \\
\text { erlands }\end{array}$ & $\begin{array}{l}\text { question- } \\
\text { naires }\end{array}$ & $\begin{array}{l}\text { the drug letter was the } \\
\text { most frequently used } \\
\text { information in the decision } \\
\text { stage, esp. section on } \\
\text { advantages and } \\
\text { disadvantages of new } \\
\text { drugs; at introduction MR } \\
\text { seems to be the most } \\
\text { frequently used source; at } \\
\text { the information stage it is } \\
\text { the Dutch Drug Bulletin; in } \\
\text { only } 20 \% \text { of the PTAM- } \\
\text { groups attention is paid to } \\
\text { the drug letter }\end{array}$ \\
\hline 93 & 1995 & $\begin{array}{l}\text { to study the effect } \\
\text { of "academic } \\
\text { group detailing" on } \\
\text { prescribing lipid- } \\
\text { lowering drugs }\end{array}$ & $\begin{array}{l}134 \text { GP } \\
\text { community } \\
\text { health } \\
\text { centres in } \\
\text { Sweden }\end{array}$ & $\begin{array}{l}\text { interven- } \\
\text { tion group } \\
\text { vs. control- } \\
\text { group }\end{array}$ & $\begin{array}{l}\text { academic group detailing } \\
\text { by pharmacists can be an } \\
\text { effective method for } \\
\text { influencing prescribing } \\
\text { practices }\end{array}$ \\
\hline 95 & 1996 & $\begin{array}{l}\text { to evaluate the } \\
\text { effect of sustained } \\
\text { clinical pharmacist } \\
\text { interventions }\end{array}$ & $\begin{array}{l}208 \\
\text { patients } \\
(>65 y)\end{array}$ & $\begin{array}{l}\text { randomize } \\
\text { d } \\
\text { controlled } \\
\text { trial }\end{array}$ & $\begin{array}{l}\text { pharmaceutical care by a } \\
\text { clinical pharmacist can } \\
\text { reduce inappropriate } \\
\text { prescribing and adverse } \\
\text { drug effects without } \\
\text { adversely affecting health- } \\
\text { related quality of life }\end{array}$ \\
\hline 106 & 1999 & $\begin{array}{l}\text { using prescription } \\
\text { data from } \\
\text { pharmacy-com- } \\
\text { puters in pharma- } \\
\text { co therapeutic } \\
\text { audit meetings }\end{array}$ & $\begin{array}{l}\text { Dutch } \\
\text { phar- } \\
\text { macies } \\
\text { and } \\
\text { PTAM's }\end{array}$ & $\begin{array}{l}\text { discussion, } \\
\text { selection } \\
\text { of } \\
\text { measures } \\
\text { and } \\
\text { suggestion } \\
\text { s }\end{array}$ & $\begin{array}{l}\text { for several aims (quality of } \\
\text { drug choice, volume, } \\
\text { costs) of audit meetings, } \\
\text { prescription data covering } \\
\text { GPs patient population } \\
\text { provide usefull information, } \\
\text { if repeat prescriptions are } \\
\text { recognised. }\end{array}$ \\
\hline
\end{tabular}




\begin{tabular}{|c|c|c|c|c|c|}
\hline $\mathbb{1 1 5 5}$ & 1999 & $\begin{array}{l}\text { to study the } \\
\text { success of the } \\
\text { model of } \\
\text { consultation by } \\
\text { GPs and } \\
\text { pharmacists in } \\
\text { Asten }\end{array}$ & $\begin{array}{l}\text { Asten, The } \\
\text { Netherland } \\
\text { s }\end{array}$ & interviews & $\begin{array}{l}\text { boltom-up consultation in } \\
\text { PTAMs in Asten resulting } \\
\text { in a computer-based } \\
\text { regional formulary } \\
\text { combining the knowledge } \\
\text { and expertise of GPs and } \\
\text { lacal pharmacists together } \\
\text { with independence from } \\
\text { information and influence } \\
\text { of pharmaceutical } \\
\text { companies make the } \\
\text { Asten model successful; } \\
\text { the low number of pre- } \\
\text { scriptions per patient and } \\
\text { low costs per prescription } \\
\text { illustrate this success }\end{array}$ \\
\hline
\end{tabular}


table 2.5 patients (age of patients, patients" demands, satisfaction and complaints)

\begin{tabular}{|c|c|c|c|c|c|}
\hline ref. & year & objective & setting & design & results / comments \\
\hline \multicolumn{6}{|c|}{ age of patients } \\
\hline 42 & 1998 & $\begin{array}{l}\text { to use the DDD } \\
\text { method to study } \\
\text { wariation in the } \\
\text { volume and cost } \\
\text { of drugs with a } \\
\text { view to comparing } \\
\text { different methods } \\
\text { of setting } \\
\text { prescribing } \\
\text { budgets }\end{array}$ & $\begin{array}{l}\text { in } 1995 \text { : } \\
129 \\
\text { general } \\
\text { practices } \\
\text { in Lothian. } \\
\text { covering } \\
808.059 \\
\text { patients }\end{array}$ & $\begin{array}{l}\text { study of } \\
\text { one year of } \\
\text { prescribing } \\
\text { statistics }\end{array}$ & $\begin{array}{l}\text { the wolume of drugs } \\
\text { prescribed for } \\
\text { "gastrointestinal", } \\
\text { cardiovascular" and } \\
\text { "endocrine" was affected } \\
\text { by age structure of prac- } \\
\text { tices; "respiratory" and } \\
\text { "CNS" by deprivation } \\
\text { structure; costs of DDD } \\
\text { largely independent of } \\
\text { age, deprivation structure } \\
\text { or fund-holding status; } \\
\text { DDD-based prescribing } \\
\text { budgets differed sub- } \\
\text { stantially from historic } \\
\text { budgets; setting budgets } \\
\text { and researching } \\
\text { prescribing variations } \\
\text { should be based on DDD } \\
\text { statistics }\end{array}$ \\
\hline 48 & 1993 & $\begin{array}{l}\text { to derive a } \\
\text { predictive model } \\
\text { for national pre- } \\
\text { scribing behaviour } \\
\text { in terms of basic } \\
\text { morbidity and } \\
\text { demographic } \\
\text { factors. }\end{array}$ & $\begin{array}{l}90 \text { family } \\
\text { health } \\
\text { service } \\
\text { authorities } \\
\text { in England } \\
\text { for } 1989 .\end{array}$ & $\begin{array}{l}24 \\
\text { demograph } \\
\text { ic, } \\
\text { morbidity } \\
\text { and prac- } \\
\text { tice factors } \\
\text { into a } \\
\text { multiple } \\
\text { regression } \\
\text { analysis to } \\
\text { determine } \\
\text { the net } \\
\text { ingredient } \\
\text { cost per } \\
\text { patient }\end{array}$ & $\begin{array}{l}2 \text { demographic factors ( } \\
\text { numbers of pensioners } \\
\text { and mobility of the } \\
\text { registered population) and } \\
2 \text { (morbidity factors: } \\
\text { standardised mortality } \\
\text { ratios and numbers of } \\
\text { prepayment certificates) } \\
\text { significantly contributed; } \\
81 \% \text { of the variation in net } \\
\text { ingredient cost per } \\
\text { registered patient was ex- } \\
\text { plained; weighting factor } \\
\text { for elderly patients was } \\
4.6 \text { ( } 3.2-6.7 .95 \% \text { ); } \\
\text { variations essentially } \\
\text { reflect demand. }\end{array}$ \\
\hline
\end{tabular}




\begin{tabular}{|c|c|c|c|c|c|}
\hline 50 & 1996 & $\begin{array}{l}\text { to demonstrate } \\
\text { wether } \\
\text { standardization of } \\
\text { practice } \\
\text { populations by } \\
\text { age and sex } \\
\text { changes the } \\
\text { internal } \\
\text { prescription } \\
\text { ranking order of a } \\
\text { group of practices }\end{array}$ & $\begin{array}{l}41 \text { GPs in } \\
35 \\
\text { practices } \\
\text { in } \\
\text { Randers, } \\
\text { Aarhus } \\
\text { county, } \\
\text { Denmark }\end{array}$ & $\begin{array}{l}\text { data on the } \\
\text { prescribing } \\
\text { of } \\
\text { cardiovasc } \\
\text { ular drugs } \\
\text { in a group } \\
\text { of practices } \\
\text { were ob- } \\
\text { tained from } \\
\text { a county- } \\
\text { based } \\
\text { database }\end{array}$ & $\begin{array}{l}\text { the change from crude to } \\
\text { standardized utillization } \\
\text { index gave an entirely } \\
\text { new ranking order of the } \\
\text { practices; the slope be- } \\
\text { tween the highest and } \\
\text { lowest ranked practice did } \\
\text { not diminish after } \\
\text { standardization; prior age } \\
\text { and sex standardization is } \\
\text { recommended when } \\
\text { comparing peer } \\
\text { prescribing patterns }\end{array}$ \\
\hline 57 & 1998 & $\begin{array}{l}\text { to identify } \\
\text { predictors of } \\
\text { antidepressant } \\
\text { pharmaco therapy } \\
\text { among patients } \\
\text { diagnosed with } \\
\text { depression and } \\
\text { predictors of } \\
\text { prescription for } \\
\text { SSRI or SNRI }\end{array}$ & $\begin{array}{l}18,046,29 \\
3 \text { office- } \\
\text { based } \\
\text { visits } \\
\text { resulting in } \\
\text { the } \\
\text { diagnosis } \\
\text { of } \\
\text { depression }\end{array}$ & $\begin{array}{l}\text { data from } \\
\text { the } 1995 \\
\text { NAMCS } \\
\text { used to } \\
\text { discern } \\
\text { variables: } \\
\text { age, race, } \\
\text { gender, } \\
\text { self-report } \\
\text { of } \\
\text { depression, } \\
\text { payer type }\end{array}$ & $\begin{array}{l}\text { the pattern of prescribing } \\
\text { antidepressant pharmaco- } \\
\text { therapy is influenced by a } \\
\text { patients' age, gender, } \\
\text { self-report of depression } \\
\text { and type of insurance } \\
\text { coverage }\end{array}$ \\
\hline 104 & 1993 & $\begin{array}{l}\text { describe temporal } \\
\text { trends in } \\
\text { prescription drug } \\
\text { use and the } \\
\text { determinants of } \\
\text { those trends }\end{array}$ & $\begin{array}{l}\text { British } \\
\text { Columbia; } \\
1981-82 \text { vs } \\
1988-89\end{array}$ & $\begin{array}{l}\text { data from } \\
\text { prescription } \\
\text { drug } \\
\text { program for } \\
\text { the elderly }\end{array}$ & $\begin{array}{l}\text { drug expenditures under } \\
\text { the program increased } \\
317 \%, 24 \% \text { to increased } \\
\text { age-specific utilization } \\
\text { rates of old drugs, } 14 \% \text { to } \\
\text { the increased size of the } \\
\text { elderly population }\end{array}$ \\
\hline
\end{tabular}




\begin{tabular}{|c|c|c|c|c|c|}
\hline \multicolumn{6}{|c|}{ patients" whishes / demands } \\
\hline 10 & 1992 & $\begin{array}{l}\text { to explore the } \\
\text { discomfort } \\
\text { experienced by } \\
\text { GPs in relation to } \\
\text { decisions about } \\
\text { wether or not to } \\
\text { prescribe }\end{array}$ & $\begin{array}{l}1 \text { family } \\
\text { practitioner } \\
\text { committee } \\
\text { in the } \\
\text { north of } \\
\text { England }\end{array}$ & $\begin{array}{l}\text { focussed } \\
\text { interviews } \\
\text { with } 74 \\
\text { respondent } \\
\text { s ( } 69 \\
\text { principal } \\
\text { GPs } 5 \\
\text { trainee } \\
\text { GPs) }\end{array}$ & $\begin{array}{l}\text { any prescribable item } \\
\text { condition could be } \\
\text { associated with dis- } \\
\text { comfort, patient } \\
\text { expectation, clinical } \\
\text { appropriateness, doctor- } \\
\text { patient- relationship and } \\
\text { precedents were main } \\
\text { reasons for the decisions; } \\
\text { concern about drug } \\
\text { toxicity, failure to live up } \\
\text { to the GP's own } \\
\text { expectations, concern } \\
\text { about appropriate treat- } \\
\text { ment, ignorance or } \\
\text { uncertainty were main } \\
\text { reasons for feeling } \\
\text { uncomfortable; many } \\
\text { considerations (medical, } \\
\text { social and logistic) } \\
\text { influenced decision to } \\
\text { prescribe; the final action } \\
\text { depends on complex } \\
\text { interaction of these } \\
\text { separate influences }\end{array}$ \\
\hline 13 & 1998 & $\begin{array}{l}\text { to better } \\
\text { understand } \\
\text { reasons for } \\
\text { antibiotics being } \\
\text { prescribed for sore } \\
\text { throats despite } \\
\text { well known } \\
\text { evidence that they } \\
\text { are generally of } \\
\text { little help }\end{array}$ & $\begin{array}{l}21 \text { GPs in } \\
\text { general } \\
\text { practices } \\
\text { in South } \\
\text { Wales and } \\
17 \text { patients }\end{array}$ & $\begin{array}{l}\text { qualitative } \\
\text { study with } \\
\text { semi- } \\
\text { structured } \\
\text { interviews }\end{array}$ & $\begin{array}{l}\text { the prescribing decision is } \\
\text { greatly influenced by } \\
\text { considerations of the } \\
\text { doctor-patient- } \\
\text { relationship, information } \\
\text { about risk to individual } \\
\text { patients might change } \\
\text { doctors' prescribing }\end{array}$ \\
\hline
\end{tabular}




\begin{tabular}{|c|c|c|c|c|c|}
\hline 14 & 1997 & $\begin{array}{l}\text { to examine the } \\
\text { effect of patients' } \\
\text { expectations for } \\
\text { medication and } \\
\text { doctors' } \\
\text { perceptions of } \\
\text { patients" } \\
\text { expectations on } \\
\text { prescribing when } \\
\text { patients present } \\
\text { with new } \\
\text { conditions }\end{array}$ & $\begin{array}{l}\text { GPS in } \\
\text { Newcastle, } \\
\text { Australia }\end{array}$ & $\begin{array}{l}\text { a } \\
\text { questionnail } \\
\text { re study } \\
\text { with } 22 \\
\text { non- } \\
\text { randomly } \\
\text { selected } \\
\text { GPs and } \\
336 \text { of their } \\
\text { patients } \\
\text { with a } \\
\text { newly } \\
\text { diagnosed } \\
\text { medical } \\
\text { condition }\end{array}$ & $\begin{array}{l}50 \% \text { of the patients } \\
\text { receiwed a prescription, } \\
\text { patients who expected } \\
\text { medication were nearly } \\
\text { three times more likely to } \\
\text { receive medication; when } \\
\text { the GP thought the patient } \\
\text { expected medication the } \\
\text { patient was } 10 \text { times more } \\
\text { likely to receive it; the } \\
\text { doctors opinion about the } \\
\text { patients' expectations } \\
\text { were the strongest } \\
\text { determinants of } \\
\text { prescribing }\end{array}$ \\
\hline 46 & 1999 & $\begin{array}{l}\text { to determine the } \\
\text { prevalence of } \\
\text { perceived patient } \\
\text { demand in } \\
\text { physician-patient } \\
\text { encounters; to } \\
\text { identify } \\
\text { characteristics of } \\
\text { the patient, } \\
\text { physician and } \\
\text { prescribing } \\
\text { situation that are } \\
\text { associated with } \\
\text { perceived demand } \\
\text { and to determine } \\
\text { the influence of } \\
\text { perceived demand } \\
\text { on physicians } \\
\text { prescribing } \\
\text { behaviour }\end{array}$ & $\begin{array}{l}\text { over a } 2- \\
\text { day period } \\
20 \text { GPs in } \\
\text { the } \\
\text { Toronto } \\
\text { area } \\
\text { prescribing } \\
\text { for } \\
\text { infectious } \\
\text { disease }\end{array}$ & $\begin{array}{l}\text { observation } \\
\text { al study by } \\
\text { questionnai } \\
\text { res and } \\
\text { interviews }\end{array}$ & $\begin{array}{l}\text { perceived patient demand } \\
\text { was reported in } 48 \% \text { of } \\
\text { the } 260 \text { encounters; in } \\
80 \% \text { the GP did not think } \\
\text { the demand of influence } \\
\text { on the prescribing } \\
\text { decision; } 82 \% \text { of the } \\
\text { patients seeking an anti- } \\
\text { infective were prescribed } \\
\text { one, } 50 \% \text { of them } \\
\text { influenced by their own } \\
\text { demand; patient demands } \\
\text { had more influence when } \\
\text { GPs were uncertain of the } \\
\text { need for an anti-infective. }\end{array}$ \\
\hline
\end{tabular}




\begin{tabular}{|c|c|c|c|c|c|}
\hline 53 & 1996 & $\begin{array}{l}\text { to compare the } \\
\text { author's } \\
\text { prescribing habits } \\
\text { for antibiotics in } \\
\text { two different work } \\
\text { settings and to } \\
\text { study the reasons } \\
\text { for the observed } \\
\text { different trends }\end{array}$ & $\begin{array}{l}\text { in } \\
\text { Scandinavi } \\
\text { a in a solo } \\
\text { practice in } \\
\text { a fishing } \\
\text { village } \\
\text { over } 1984- \\
87 \text { and a } \\
\text { group } \\
\text { practice in } \\
\text { a town } \\
\text { over } 1987- \\
92\end{array}$ & $\begin{array}{l}\text { a retro- } \\
\text { spective } \\
\text { database } \\
\text { study of } \\
\text { computer- } \\
\text { based } \\
\text { patient re- } \\
\text { cords }\end{array}$ & $\begin{array}{l}\text { in the solo-practice the } \\
\text { GP reduced the number } \\
\text { of prescriptions for } \\
\text { antibiotics significantly } \\
\text { from } 82.9 \text { to } 63.8 \text { per } \\
1000 \text { contacts; in the } \\
\text { group practice the number } \\
\text { increased from } 82.6 \text { to } \\
90.5 \text { (NS); there was an } \\
\text { increase of workload } \\
\text { during the (latter)study } \\
\text { period(s), with a looser } \\
\text { affiliation to the patient } \\
\text { group; the expectations of } \\
\text { the patients, the } \\
\text { surrounding of the doctor } \\
\text { and his work environment } \\
\text { determine to a great } \\
\text { extent his antibiotic } \\
\text { prescribing habits }\end{array}$ \\
\hline 88 & 1999 & $\begin{array}{l}\text { review strategies } \\
\text { that may influence } \\
\text { prescribing and } \\
\text { discussion }\end{array}$ & $\begin{array}{l}\text { review } \\
\text { article }\end{array}$ & $\begin{array}{l}\text { review } \\
\text { article }\end{array}$ & $\begin{array}{l}\text { concerning tolerance the } \\
\text { patient has a major } \\
\text { influence on prescribing, } \\
\text { communication between } \\
\text { healthcare providers } \\
\text { assumes a vital role }\end{array}$ \\
\hline
\end{tabular}




\begin{tabular}{|c|c|c|c|c|c|}
\hline \multicolumn{6}{|c|}{ patients" satisfaction } \\
\hline 19 & 1995 & $\begin{array}{l}\text { to observe } 1 \mathrm{GPs} \text { " } \\
\text { practice attempt to } \\
\text { reduce prescribing } \\
\text { costs through the } \\
\text { introduction of a } \\
\text { generic formulary } \\
\text { and to assess the } \\
\text { impact on patients } \\
\text { and prescribing } \\
\text { patterns }\end{array}$ & $\begin{array}{l}1 \text { urban } \\
\text { practice } \\
\text { with } 5 \\
\text { partners in } \\
\text { Scotiand, } \\
1993\end{array}$ & $\begin{array}{l}\text { observation } \\
\text { al study by } \\
\text { interviews } \\
\text { with pa- } \\
\text { tients and } \\
\text { GPs and } \\
\text { re-search } \\
\text { of repeat } \\
\text { pre-script- } \\
\text { ions to } \\
\text { identify } \\
\text { changes in } \\
\text { prescription }\end{array}$ & $\begin{array}{l}\text { the practice achieved a } \\
\text { large reduction in pre- } \\
\text { scribing costs rapidly } \\
\text { (onset within } 4 \text { months) } \\
\text { caused by generic } \\
\text { substitution and a } \\
\text { reduction of the volume of } \\
\text { treatment dispensed, the } \\
\text { changes were tolerated } \\
\text { by patients, none of whom } \\
\text { is thought to have left the } \\
\text { practice for this reason, } \\
\text { great care must be taken } \\
\text { to inform patients } \\
\text { appropriately }\end{array}$ \\
\hline 40 & 1997 & $\begin{array}{l}\text { to assess three } \\
\text { prescribing } \\
\text { strategies for sore } \\
\text { throat }\end{array}$ & $\begin{array}{l}11 \text { general } \\
\text { practices } \\
\text { in South } \\
\text { and West } \\
\text { region of } \\
\text { the UK }\end{array}$ & $\begin{array}{l}\text { prospective } \\
\text { randomised } \\
\text { study over } \\
714 \text { pa- } \\
\text { tients in } \\
\text { three } \\
\text { groups } \\
\text { ( } 81 \% \text { docu- } \\
\text { mented } \\
\text { subjects) }\end{array}$ & $\begin{array}{l}\text { prescribing antibiotics for } \\
\text { sore throats only } \\
\text { marginally affects the } \\
\text { resolution of symptoms, } \\
\text { but enhances belief in } \\
\text { antibiotics and intention to } \\
\text { consult in future when } \\
\text { compared with the } \\
\text { acceptable strategies of } \\
\text { no prescription or delayed } \\
\text { prescription }\end{array}$ \\
\hline 77 & 1996 & $\begin{array}{l}\text { description of one } \\
\text { practice reducing } \\
\text { prescribing } \\
\text { expenditure as a } \\
\text { part of the move to } \\
\text { fundholding }\end{array}$ & $\begin{array}{l}53 \\
\text { interviews } \\
\text { with } 17 \\
\text { patients }\end{array}$ & $\begin{array}{l}\text { interviews } \\
\text { with } \\
\text { practice } \\
\text { staff and } \\
\text { patients, } \\
\text { prescribing } \\
\text { statistics } \\
\text { and } \\
\text { questionnai } \\
\text { re }\end{array}$ & $\begin{array}{l}\text { most patients were willing } \\
\text { to try cheaper treatments, } \\
\text { dissatisfaction was } \\
\text { primarily with the } \\
\text { communication; large- } \\
\text { scale economies in } \\
\text { prescribing are feasible } \\
\text { for some practices, and } \\
\text { patients will tolerate such } \\
\text { changes if attention is } \\
\text { paid to sensitive } \\
\text { communication }\end{array}$ \\
\hline
\end{tabular}




\begin{tabular}{|c|c|c|c|c|c|}
\hline 80 & 1995 & $\begin{array}{l}\text { to learn more } \\
\text { about patients" } \\
\text { awareness of and } \\
\text { attitude about gifts } \\
\text { to GPs from } \\
\text { pharmaceutical } \\
\text { companies }\end{array}$ & $\begin{array}{l}\text { the wating } \\
\text { rooms of } \\
\text { two family } \\
\text { practices } \\
\text { in central } \\
\text { Missouri }\end{array}$ & $\begin{array}{l}\text { self- } \\
\text { administere } \\
\text { d ques- } \\
\text { tionnaire }\end{array}$ & $\begin{array}{l}\text { respondents distinguished } \\
\text { between particular gifts, } \\
\text { approval rates were high } \\
\text { for gifts generally } \\
\text { considered to be trivial or } \\
\text { that have potential value } \\
\text { to patient care; } \\
\text { disapproval rates were } \\
\text { relatively high for gifts that } \\
\text { have some monetary } \\
\text { value but have little or no } \\
\text { benefit for patients; } \\
\text { opinions about gifts were } \\
\text { related to perceptions of } \\
\text { their effects on } \\
\text { prescribing behaviour and } \\
\text { costs }\end{array}$ \\
\hline 83 & 1998 & $\begin{array}{l}\text { to compare } \\
\text { physicians' and } \\
\text { their patients' } \\
\text { attitudes toward } \\
\text { pharmaceutical } \\
\text { gifts }\end{array}$ & $\begin{array}{l}\text { two tertiary } \\
\text { medical } \\
\text { centres: } \\
\text { one } \\
\text { military } \\
\text { and one } \\
\text { civilian }\end{array}$ & $\begin{array}{l}\text { survey of } \\
\text { physicians } \\
\text { and their } \\
\text { patients }\end{array}$ & $\begin{array}{l}10 \text { pharmaceutical gifts } \\
\text { were rated: whether of not } \\
\text { appropriate; whether or } \\
\text { not likely to influence } \\
\text { prescription behaviour; } \\
\text { patients feel } \\
\text { pharmaceutical gifts less } \\
\text { appropriate and more } \\
\text { influential then physicians }\end{array}$ \\
\hline 84 & 1997 & $\begin{array}{l}\text { to consider the } \\
\text { relationship } \\
\text { between MRs and } \\
\text { physicians in the } \\
\text { framework argued } \\
\text { for by Engelhardt }\end{array}$ & & $\begin{array}{l}\text { philosophic } \\
\text { al } \\
\text { considerati } \\
\text { an }\end{array}$ & $\begin{array}{l}\text { four major criticisms on } \\
\text { MR-physician relation- } \\
\text { ships are: influence, } \\
\text { patients,donot chross, } \\
\text { but they pay, violation of } \\
\text { ethical principles and } \\
\text { erosion of the patient- } \\
\text { physician relationship; } \\
\text { each is shown } \\
\text { unpersuasive under } \\
\text { Engelhardtian philosophy; } \\
\text { as long as the principle of } \\
\text { permission and informed } \\
\text { consent is obtaine without } \\
\text { coercion, the interaction } \\
\text { would be construed to be } \\
\text { morally permissible }\end{array}$ \\
\hline
\end{tabular}




\begin{tabular}{|c|c|c|c|c|c|}
\hline 90 & 1999 & $\begin{array}{l}\text { voluntary changes } \\
\text { in antiemetic } \\
\text { prescribing } \\
\text { practice }\end{array}$ & $\begin{array}{l}\text { post-anes- } \\
\text { thesia care } \\
\text { unit in an } \\
\text { academic } \\
\text { medical } \\
\text { center }\end{array}$ & $\begin{array}{l}\text { prospective } \\
\text { obesenvatio } \\
\text { nal study } \\
\text { with ran- } \\
\text { domized } \\
\text { component }\end{array}$ & $\begin{array}{l}\text { patients satisfaction be- } \\
\text { tween ondansetron } 4 \mathrm{mg} \\
\text { and droperidol } 0,625 \mathrm{mg} \\
\text { did not differ in spite of } \\
\text { slightly greater efficacy of } \\
\text { ondiansetron }\end{array}$ \\
\hline \multicolumn{6}{|c|}{ patients' complaînts } \\
\hline 88 & 1999 & $\begin{array}{l}\text { to review strate- } \\
\text { gies that may in- } \\
\text { fluence prescrib- } \\
\text { ing behaviour and } \\
\text { to discuss practi- } \\
\text { cal considerations } \\
\text { for achieving opti- } \\
\text { mal prescribing in } \\
\text { view of tolerablity } \\
\text { concerns }\end{array}$ & $\begin{array}{l}\text { The Neth- } \\
\text { erlands }\end{array}$ & $\begin{array}{l}\text { review and } \\
\text { discussion }\end{array}$ & $\begin{array}{l}\text { the patient has a major } \\
\text { influence on prescribing; } \\
\text { communication between } \\
\text { health care workers as- } \\
\text { sumes a vital role, mes- } \\
\text { sages regarding patients } \\
\text { prescribing patterns and } \\
\text { drug tolerability should be } \\
\text { coherent and transferable. }\end{array}$ \\
\hline
\end{tabular}


CHAPTER III

OUTLINE OF THE INVESTIGATION 
Introduction. In modern medicine pharmacotherapy is an important part of the treatment of many patients suffering from various diseases. For the physicians who consider themselves responsible for optimal treatment of their patients, the selection of drugs is often not an easy task. Not only the uncertainty of favourable action of prescribed drugs in a number of cases but also the possibly occurring unwanted side effects have to be taken into consideration. Moreover, the doctor's opinion on treatment and drugs to be administered is not always in line with the expectations of the patient (14). Refusal to prescribe drugs could lead to misunderstanding or in extreme cases even to legal malpractice claims against the doctor (6). But the prescription of drugs which do not meet the patient's expectations or cause annoying and sometimes dangerous side effects might have the same consequences. Moreover, there is constant pressure on prescribing physicians to reduce the ever increasing rise of expenditures for pharmacotherapy $(66,136)$. In short, the selection of appropriate drugs is not only a difficult but also a highly responsible activity.

A possible source of inconsistent drug selection is the wide range of different chemical entities in almost every category of drugs from which an appropriate choice must be made. Professional societies recognised this problem and published guidelines $(27,47,97)$ including recommended drug therapy for the treatment of a number of diseases, e.g. the NHG-guidelines from the Dutch College of General Practitioners (147). These are important items for discussion in pharmaco-therapeutic audit meetings (PTAMs) where selection and administration of drugs are studied by general practitioners and pharmacists together (155). Information is also provided by the pharmaceutical industry which as a matter of fact is interested in introduction of new drugs which often have to proof its value in daily practice. A prescription policy of 'trial and error' can thus be induced and the results of such trials can be rather confusing to the prescribers of the new drugs and sometimes not without risk for the patients $(41,103)$.

In some PTAMs regional formularies have been composed based on the experience and expertise of the participants. These formularies contained a restricted list of drugs in order to avoid too many problems in drug selection. The participating GPs then agreed to aim at prescription within the scope of the formulary considering that prescription of a limited number of drugs might contribute to increased experience and expertise. Moreover, "trial and error" prescription behaviour could thus be avoided.

The main source of information on the prescribing behaviour of general practitioners are the prescriptions which they hand out to their patients. Studying these prescriptions over an extended period of time will provide data on consis- 
tency and instability of prescription behaviour. Many consequences of this behaviour, both of medical and social character, have a direct influence on the daily practice of medicine. Rational prescription policy is of utmost importance and has to keep in pace with developments in pharmacotherapy. Increasing knowledge of diseases and insight in the basic biochemistry of pathological processes goes in line with the introduction of newly developed drugs and causes longitudinal changes in selection of chemical entities as preferable drugs for treatment. These changes reflect the prescription behaviour of individual physicians and its effects on the practice of general medicine.

Having reviewed the literature (cf.chapter I) we decided to study the following items with the aim to contribute to increased insight in the prescription behaviour of GPS and its longitudinal developments:

- the prescription behaviour of physicians in general practice without special agreements on drug selection and prescription ('unbound prescription');

- the prescription behaviour of GPs who aimed at prescribing within the limits of a regional limited formulary ('formulary-bound prescription');

- influence of the formulary on several aspects of prescription policy: a comparative study;

- the subjective evaluation of their prescription behaviour by the GPs;

- the influence of formulary-bound prescription policy on expenditures of pharmacotherapy.

The general practitioners. Seven GPs in the 'unbound prescription' group (reference-group; R-group) were retrospectively selected for participation on the criterion that they were geographically situated near the central pharmacy and that the patients were for their prescriptions mainly oriented at the central pharmacy. They were free to select any drug from one of the included ATCcategories. The GPs provided health care for a population of 19,000 patients in a middle-size Dutch town.

As a comparable group (audit-group; A-group) seven GPs were selected who voluntarily aimed to keep their prescriptions within the scope of a limited formulary (A-formulary) which had been composed in common discussion and agreement in monthly pharmaco-therapeutic audit meetings. This 'formulary bound prescription" group provided health care in a semi-rural region for a population of 14,000 patients.

In order to avoid influence of the GPs by changing their prescription behaviour during the course of the investigation as a result of the study, prescription data were collected retrospectively and single-blind. This means that during the 
collection of the prescriptions the GPs were not aware of the ongoing procedure. They were informed after completion of collection of all prescriptions whereupon their permission to use the collected data for investigation was requested and obtained.

Data on physicians and practices are summarised in table 3.1 .

Categories of drugs. An important aspect was the selection of drug categories from the Anatomical Therapeutical Chemical (ATC) Classification, which were to be included in the study. In each category a sufficient number of interchangeable chemical identities should be available for proper selection and the study should include a broad spectrum of common diseases for which prescription of drugs from the selected categories was medically indicated. These criteria were satisfied by the following six ATC-categories, i.e. NSAIDs (ATC-code M01A), ACE inhibitors (C09A), antidepressants (N06A), beta-blocking agents (C07A), calcium-channel blocking agents $(\mathrm{COBC})$ and cholesterol synthesis inhibitors (C10AA). The total number of different chemical entities in these categories together amounted up to 77 drugs (table 3.2).

Special attention had to be paid to the drugs listed in viz. the A-formulary and the NHG-guidelines. In agreement with other investigators $(210,222)$ we decided to designate 'drugs of personal preference' those that would be prescribed in more than $10 \%$ of the total prescriptions in its category.

The Asten formulary. Since 1979 GPs and pharmacists in Asten/southern Netherlands meet to discuss pharmaco-therapy. The electronic version of the agreements from these meetings has been implemented in the practice computer of the GPs in 1997 as the "Asten formulary". It automatically produces the first, second and third choice pharmaco-therapeutic treatment after giving the ICPC as a diagnosis. Reconsideration and updating the formulary follows the changes of the NHG-guidelines (table 3.3). Notwithstanding the fact, that the formulary did not meet all recommendations made by Kamps (64), we judged the compliance with the Asten formulary to be a good audit compliance, because the formulary had a long history and proved ten years of good implementation and thorough acceptance by the GPs in Asten (155).

The prescriptions. In the R-group ('unbound' prescription) any selection from the total list of 77 different drugs in the combined six ATC-categories could be made. NHG-guidelines could have an influence on the actual selection of the drug to be prescribed. 
In the A-group ("formulary bound" prescription) only a limited number of drugs per ATC-category was voluntarily listed in a formulary of preference: the Aformulary. This formulary was computerised and easily accessible on the doctor's desk. It must be kept in mind that the possibility to deviate from the formulary in special cases still existed but this required extra effort from the GPS. The GPs in the A-group voluntarily aimed to restrict their prescriptions to the drugs from the A-formulary but strict obligation was not agreed.

Repeat prescriptions could not be distinguished from initial prescriptions, nor could we detect if prescriptions were originally started by the actual prescribing GP. For each patient under treatment, however, the general practitioner decided the most appropriate drug to be prescribed and was responsible for this (repeat)prescription. Every repeat prescription grants the prescriber the opportunity and the responsibility to decide wether to repeat, change or stop medication, or to refer the patient back to the original prescriber.

In order to investigate the selection process all prescriptions per active ingredient from each individual prescriber were to be collected and counted. A clear picture of each physician's prescription behaviour would thus be obtained.

Time span. It was decided that the prescriptions would retrospectively be collected and accordingly be classified in seven half year groups. When we started the collection of the data we could not go back further than three and a half year which is why we classified seven half year periods. In each half year group the drugs were subdivided according to ATC-categories. The chosen time span of half year periods enabled us to collect a sufficient number of prescriptions per period. Moreover, registration of drug selection bias of short duration e.g. from trial prescriptions would thus be avoided.

The pharmacies. The central pharmacy in the R-group is a community pharmacy in the centre of a middle size Dutch town under the direction of two pharmacists. Five other pharmacies are located within a range of three kilometres. Prescriptions of about $70-80$ different prescribers, GPs as well as consultants/specialists from the central hospital, are handled in the R-pharmacy. There are no special reasons for prescribers to refer specific patients to the pharmacy nor do patients have special reasons to visit the pharmacy, other than the convenience of the location.

The central pharmacy in the A-group, also under management of two pharmacists, is the only pharmacy in this region. Patients who want to visit an other pharmacy have to travel more than 10 kilometres. Prescriptions of about $20-45$ different prescribers are handled in the A-pharmacy. 
The pharmacists. The pharmacists of the A-group pharmacy, strongly involved in PTAMs of the A-group, were only informed and asked for their cooperation after the period of our study had passed and the actual retrospective data collection was to be started. Their cooperation was kindly granted to us in 1999. The pharmacists of the R-group-pharmacy were informed and asked for their cooperation in 1996, but they were not involved in the PTAMs of the Rgroup. There was no structured pharmaco-therapeutical consultation between the GPs of the R-group and the pharmacists of the R-region pharmacy.

The pharmacy computer system. The computer system used in both the Rpharmacy and in the A-pharmacy is the Euroned Apcos system. This is an administrative database for declaration, data-storage and surveillance of interactions and contra-indications, used for these purposes in about 700 pharmacies in the Netherlands. The Euroned system stores all relevant data of all prescriptions that are processed in the pharmacy. Among these data are the personal code of the prescriber and the ATC-code of the drug that is prescribed and delivered. Data are stored with easy access for at least 5 years in each pharmacy. The data for the numbers of prescriptions have been retrieved from the computer by a Musqle script, that sorts all prescriptions within ATC-classification in a given period according to the different prescribers. The data in the system concern all prescriptions that have been filled by the pharmacy and delivered to the patient. The system automatically assigns the ATC-code to the prescription after typing the name of the drug. The records are used for financial and stock administration and pharmacotherapeutical surveillance of dosage, contraindications and interactions is built on them. All prescriptions are checked and double checked every day with the computer print-out. Pharmacotherapeutical errors are corrected immediately, because of the medication surveillance. Administrative errors are corrected before the end of the month, when the claims for the insurance companies and individual patients are due to be made.

Pharmaco-therapeutic audit meetings. Both the GPs in the R-group and the GPs in the A-group participated in PTAMs. The GPs in the R-group were divided among two different PTAM-groups with participation of local pharmacists. The GPs in the A-group formed one PTAM-group with the pharmacists of the central pharmacy. Medical representatives from the pharmaceutical industry were regularly received by each individual physician in the R-group. The GPs in the A-group decided that medical representatives would be received by the 
local pharmacists and that the obtained information be distributed and discussed during the monthly audit meetings.

Longitudinal changes in selection of drugs for prescription. In order to evaluate the longitudinal changes in preference for the prescription of certain drugs, the number of prescriptions for each drug in its ATC-category in every half year period would be registered. The varying numbers of prescriptions for each drug from one period to another demonstrate the changing preferences.

NHG-guidelines. NHG-guidelines are widely known and recognised plausible options for treatment policy (149) and standards by law as national guidelines for good medical practice in primary care setting (150). Therefore we decided that these guidelines could be used to measure and judge compliance, even in a group of GPs, who were free to choose to prescribe any suitable drug on the Dutch market. In order to do so we searched all NHG-guidelines (147) to detect the standards that recommended drugs within the ATC-categories in our study. An overview of these standards, as well as the dates of changes, are presented in table 3.3 .

Compliance with A-formulary and NHG-guidelines. The compliance with both the A-formulary (for the A-group) and the NHG-guidelines (for the R-group and for the A-group) must be checked. Although none of the groups or individual GPs was bound in any way to follow the NHG-guidelines, it was decided that compliance had to be measured because influence on prescription behaviour could not be excluded or even might be supposed. The longitudinall course of compliance with the NHG-guidelines and with the A-formulary had to be registered to provide information on prescription discipline.

Expenditures for pharmacotherapy. Control of expenditures for pharmacotherapy in general practice is an actual problem and is highly dependent on the prescription behaviour of GPs. The latter might be dependent on practice characteristics such as patients' age categories and morbidity patterns. Influence of deliberate prescription behaviour such as prescription in line with guidelines or a formulary must be considered as well.

Comparing available data between the R-region and the A-region and the influence of formulary-bound prescription was supposed to provide a valuable contribution to our study. 
Data collection and data processing. It was decided that the collected data would be processed in such a way that information was obtained on various aspects of prescription behaviour of each individual physician such as the selection of drugs of personal preference, longitudinal changes in selection behaviour and compliance with formulary and/or guidelines for pharmacotherapy. Differences between prescription policies of R-group and A-group were to be registered and will be discussed in the following chapters.

Another procedure of data collection was performed through the computer of the regional health insurance company. From the computerised monthly claims by community pharmacies the regional health insurance company has built a data base. Data from this data base can be asked for by PTAM-groups to be used for feedback on prescription policy.

Retrospective evaluation of prescription behaviour. The obtained results were to be discussed with the participating physicians. This retrospective evaluation aimed at self reported reasons for changes and stabilities. Several possibilities for influence on prescription behaviour were considered such as PTAMs, visits by medical representatives, the existence of a common formulary, etc. Whether the GPs on retrospection were aware of such aspects and how they looked back and/or wanted to change their behaviour was of utmost interest for future prescription policy.

Contacts between GPs" and pharmacists' computer systems. In the Agroup all practice computers were connected to the pharmacy computer. Five GPs of the R-group had an electronic connection between their practice computer and the pharmacy computer. From these practices electronic prescriptions were sometimes sent. Two GPs could not send electronic prescriptions. Paper prescriptions from all seven GPs were processed in the pharmacy. The difference between processing electronic prescriptions and paper prescriptions is that the electronic prescription automatically produces the drug and the dosage chosen by the prescriber whilst from the paper prescriptions these have to be read and typed in the computer. Both the selection of the drug and the dosage of the electronic and the paper-written prescriptions can be changed in the pharmacy when necessary or after feed-back consultation.

References: cf. general reference list (chapter II). 
table 3.1. Combined data on practices of GPs in the Audit-group and in the Reference-group.

\begin{tabular}{|c|c|c|}
\hline & A-group & R-group \\
\hline nr. GPs & 7 & 7 \\
\hline $\begin{array}{l}\text { total nr. patients } \\
\text { nr. NHS-registered patients * } \\
\text { (compulsory health insurance) }\end{array}$ & $\begin{array}{l}13,899 \\
8,395 \\
(60 \% \text { of total nr. })\end{array}$ & $\begin{array}{l}19,087 \\
10,358 \\
(55 \% \text { of total nr. })\end{array}$ \\
\hline 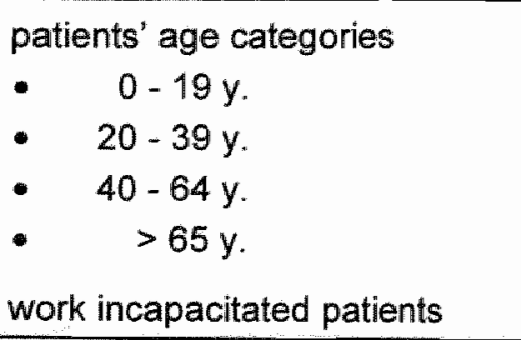 & $\begin{array}{l}22.4 \% \\
32.1 \% \\
30.1 \% \\
15.4 \% \\
7.3 \% \\
\end{array}$ & $\begin{array}{r}15.8 \% \\
31.4 \% \\
31.9 \% \\
20.9 \% \\
8.2 \% \\
\end{array}$ \\
\hline $\begin{array}{l}\text { prescribed drugs selected from } \\
\text { nr. different drugs availlable }\end{array}$ & $\begin{array}{l}\text { A-formulary (priority) } \\
\text { and ATC-list } \\
\text { formulary: } \\
15 \text { drugs }\end{array}$ & $\begin{array}{l}\text { complete ATC-list; } \\
\text { no formulary } \\
77 \text { drugs }\end{array}$ \\
\hline
\end{tabular}

* number of statutorily insured patients, registered following the National Healthcare System (NHS) 
table 3.2. ATC-categories with indication of drugs listed in the A-formulary and in the NHG-guidelines.

\begin{tabular}{|c|c|c|c|c|c|}
\hline NSAIDS & $\begin{array}{l}\text { ACE- } \\
\text { inhibitors }\end{array}$ & $\begin{array}{l}\text { anti- } \\
\text { depressants }\end{array}$ & $\begin{array}{l}\text { beta-blocking } \\
\text { agents }\end{array}$ & $\begin{array}{l}\text { Ca-chaninel } \\
\text { block. }\end{array}$ & $\begin{array}{l}\text { chol. } \\
\text { inhibitors }\end{array}$ \\
\hline M01A & $\operatorname{CogA}$ & N06A & C07A & $\mathrm{COBC}$ & C10AA \\
\hline \multicolumn{6}{|l|}{ A-formulary } \\
\hline diclofenac & Captopril & paroxetine & atenolol & nifedipine & simvastatin \\
\hline ibuprofen & enalapril & clomipramine & pindolol & amlodipine & pravastatin \\
\hline nabumetone & & moclobemide & & & fluvastatin \\
\hline \multicolumn{6}{|l|}{ NHG-guidelines } \\
\hline diclofenac & captopril & amitriptyline & atenolol & nifedipine & simvastatin \\
\hline buprofen & enalapril & imipramine & metoprolol & nitrendipine & pravastatin \\
\hline naproxen & & fluvoxamine & & & \\
\hline \multicolumn{6}{|l|}{ complete ATC-list } \\
\hline aceclofenac & benazepril & amitriptyline & acebuttolo & amiodipine & atorvastatin \\
\hline azapropazone & captopril & citalopram & alprenolol & felodipine & cerivastatin \\
\hline diclof./misopr. & cilazapril & clomipramine & atenolol & irsadipine & fluvastatin \\
\hline diclofenac & enalapril & desipramine & betaxolol & lacidipine & pravastatin \\
\hline fenylbutazone & fosinopril & dosulepine & bisoprolol & lercanidipine & simvastatin \\
\hline flurbiprofen & lisinopril & doxepine & carvedilol & mibefradil " & \\
\hline ibuprofen & perindopril & fluoxetine & celiprolol & nicardipine & \\
\hline indometacin & quinaprill & fiuvoxamine & labetalol & nifedipine & \\
\hline ketoprofen & ramipril & imipramine & metoprolol & nimodipine & \\
\hline meloxicam & trandolapril & maprotiline & nebivolol & nisoldipine & \\
\hline nabumetone & & mianserine & oxprenolol & nitrendipine & \\
\hline naproxen & & mirtazapine & pindolol & & \\
\hline piroxicam & & moclobemide & propanolol & & \\
\hline tenoxicam & & nefazodone & sotalol & & \\
\hline tiaprof. acid & & nortriptyline & tertatolol & & \\
\hline \multirow[t]{5}{*}{ tolfenamic acid } & & paroxetine & & & \\
\hline & & sertraline & & & \\
\hline & & trazodone & & & \\
\hline & & trimipramine & & & \\
\hline & & venlafaxine & & & \\
\hline total numbers 16 & 10 & 20 & 15 & 11 & \\
\hline
\end{tabular}

* withdrawn from the market on account of interactions 
table 3.3. NHG-guidelines concerning the ATC-categories M01A (NSAIDs), C09A (ACE-inhibitors), N06A (antidepressants), C07A (beta-blocking agents), C08C (Ca-channel blocking agents) and/or C10AA (cholesterol synthesis inhibitors).

\begin{tabular}{|c|c|c|c|c|c|}
\hline \multirow[t]{2}{*}{ nr. } & \multirow[t]{2}{*}{ diagnosis } & \multirow{2}{*}{$\begin{array}{l}\text { date of } \\
\text { last } \\
\text { change }\end{array}$} & \multirow[t]{2}{*}{$\begin{array}{l}\text { ATC- } \\
\text { category }\end{array}$} & \multicolumn{2}{|c|}{$\begin{array}{l}\text { change of importance for this } \\
\text { study }\end{array}$} \\
\hline & & & & $\mathrm{NHG}$ & $\begin{array}{l}\text { dev. } \\
\text { A-form. }\end{array}$ \\
\hline M08 & shoulder compl. & 1999 & M01A & & 1 \\
\hline M17 & hypertension & 1999 & $\begin{array}{l}\text { CO7A } \\
\text { C08C } \\
\text { CO9A }\end{array}$ & $\begin{array}{l}\text { CO8A and CO9A in } \\
\text { first step treat- } \\
\text { ment }\end{array}$ & 2,3 \\
\hline M19 & migraine & 1999 & $\begin{array}{l}\text { M01A, } \\
\text { C07A }\end{array}$ & & 1,2 \\
\hline M2O & elev. blood chol. & 1999 & C1OAA & $\begin{array}{l}\text { C1OAA in first step } \\
\text { treatment; } \\
\text { enlarged diagnos. }\end{array}$ & \\
\hline M41 & rheum. arthritis & 1996 & Mo1A & & 1 \\
\hline M43 & angina pectoris & 1996 & $\begin{array}{l}\text { CO7A } \\
\text { COBC }\end{array}$ & & 2,3 \\
\hline M44 & mental depress. & 1994 & No6A & & 4 \\
\hline M51 & heart failure & 1995 & CogA & C09A basic ther. & \\
\hline M54 & low back pain & 1996 & M01A & & 1 \\
\hline M55 & $\begin{array}{l}\text { lumbosacral radic. } \\
\text { syndrome }\end{array}$ & 1996 & M01A & & 1 \\
\hline M60 & epicondylitis & 1997 & M01A & & 1 \\
\hline M62 & anxiety disorders & 1997 & NO6A & $\begin{array}{l}\text { fluvoxamine } \\
\text { added }\end{array}$ & 4 \\
\hline M63 & urin tract stones & 1997 & M01A & & 1 \\
\hline M69 & osteoporosis & 1999 & M01A & & 1 \\
\hline
\end{tabular}

legend deviations A-formulary: 1. nabumetone instead of naproxen; 2 . pindolol i.o. metoprolol; 3. amlodipin i.o. nitrendipin; 4. paroxetin, clomipramin and moclobemide instead of amitriptylin, imipramin and fluvoxamin. 
CHAPTER IV

LONGITUDINAL CHANGES IN 'UNBOUND' DRUG PRESCRIPTION 
Introduction. General practitioners treating their patients with drugs can often choose between interchangeable drugs from the same category. This may well lead to variation in prescription not only between different family physicians ( 3 , $9,24,38,44,51,58$, ) but also by one physician in the course of time (4). However, to increase knowledge on the optimal treatment of a certain disease an efficient use of drugs and avoiding much variation in the choice of these is to be preferred $(62,210)$. In this way the experience of the individual prescriber accumulates and his/her specific knowledge increases. Therefore there is a tendency to base the prescription policy in general practice on up to date medical scientific knowledge (64). Several (other) interventions to minimise the gap between optimal prescribing and practice have more or less successfully been tried (73). The use of guidelines can be greatly facilitated when all prescribing is done by computer from a limited drug formulary $(74,75,153)$. It may be supposed that a physician using a consistent prescription policy has a preference for certain drugs based on sound criteria. Such an attitude will lead to what could be called a narrow prescription spectrum in favour of increased personal experience. Otherwise in most cases the decision making process of family physicians in choosing drugs depends on evoked set /ready memory (68) and will inevitably be influenced by, among other things, a wide choice and the introduction of new drugs $(8,54)$. Another important development is the growing impact of regionally organised pharmaco-therapeutic audit meetings, so called FTO-meetings, for discussion and consultation between physicians and pharmacists on aspects of optimising drug therapy (76).

The extent of variability in prescription policy will vary between doctors. This variation can be studied and audited by collection of all prescriptions from different physicians linked to a central data base $(89,106)$.

In order to obtain detailed information on this subject we started an investigation on the following aspects of drug prescription in general practice:

- what is the extent of variability in choice between interchangeable drugs in a certain category at any moment in a group of physicians working in similar circumstances;

- which variability is observed in the prescription policy of each individual physician over an extended period of time:

- to what extent physicians tend to adhere to proposed standards of treatment (prescription guidelines of the Dutch College of General Practitioners; $\mathbb{N H G}$ );

- which longitudinal changes in selection of drugs can be observed in a group of general practitioners over an extended period of time. 


\section{Methods}

Data collection. Prescription data were retrospectively collected from the computerised administration system of the dispensing central pharmacy through which all of the drugs in this study were delivered. In this pharmacy all prescriptions from the general practitioners were collected and registered. Only data were used from general practitioners from whom in the foregoing 42 months a sufficient number of prescriptions had been received.

The general practitioners. The GPs were retrospectively selected for participation on the criterion that they were geographically situated near the central pharmacy and that the patients were for their prescriptions mainly oriented at the central pharmacy. Together they were designated as R-group (University of Maastricht group).

All doctors had their practice in a middle size Dutch town. Four of them worked independently each in his own practice whilst three others participated in two group practices. Together they were serving a population of 19,000 people, each practice containing between 2500 and 3000 patients. The rate of compulsory vs. voluntary NHS-insured patients varied from 40-60\%. Only one of the GPs mentioned a majority of patients over 65 years of age in his practice. Overall no significant differences between the practices were reported. The age of the GPs ranged from 40-55 years. They all worked in their practice for many years.

In order to avoid deliberate influence of the GPs on the course of the investigation, the prescriptions have retrospectively been collected over seven consecutive half-year periods in a semi blind procedure. This means that not earlier than after collection of all data the general practitioners have been informed. Their permission was then asked to include their prescription data in our study and their cooperation for evaluation of the processed data was requested. They all eagerly agreed with the only restriction that their prescription data would be anonymised before publication.

Categories of drugs. A number of different categories of drugs have been selected so that in each of them a sufficient number of prescriptions could be collected. For NSAIDs and antidepressants this means that at least 200 prescriptions in any period of six months were collected. An important criterion was also that a sufficient number of interchangeable drugs in any category should be available to make an individual choice possible. The six following drug categories (with ATC codes) fulfilling these criteria were selected for investigation: NSAIDs (ATC code M01A), ACE inhibitors (CO9A), antidepressants 
(NO6A), beta-blocking agents (C07A), calcium channel blocking agents (C08C) and cholesterol inhibitors (C10AA). Those drugs for which in any period of six months the number of prescriptions exceeded $10 \%$ of total prescriptions in its group, were designated as 'drugs of personal preference". Comparable procedures have been published by other investigators $(113,210)$. Prescriptions where this $10 \%$ limit was not reached were collected in a so called rest group designated as 'other drugs'. In the other categories the number of available drugs allows to mention them all.

Time span. All prescriptions have retrospectively been collected during seven consecutive half year periods and were accordingly classified in seven groups. In each half year group the drugs were subdivided in ATC-categories. The time span of half year periods enabled us to collect a sufficient number of prescriptions per period. Moreover, registration of drug selection bias of short duration could thus be avoided. This occurs sometimes e.g. as trial prescriptions during a short period after introduction of new drugs. All prescription data concerning the consecutive six months periods and over the entire period of three and a half years were processed and studied.

The prescriptions. For each new prescription the physician decides on the most appropriate drug which he wants to prescribe for the patient under treatment. The first step in this decision process is the selection of a category of drugs followed by the choice of an active ingredient c.q. chemical entity in this category. This determines which drug actually is prescribed. For this study drugs were selected from six ATC-categories containing together a total number of 77 different drugs. Prescriptions were selected on chemical entity without consideration of dosage, way of administration and/or nature of the disease for which the drug was prescribed. Assuming that all prescriptions are clinically indicated the Dutch College of General Practitioners (NHG) provides treatment guidelines for a number of diseases suggesting prescription of specified drugs. No obligation whatever existed to follow these guidelines by the prescription of recommended drugs.

The selection process was studied by collecting and counting all prescriptions from each individual prescribing GP per active ingredient. This was done retrospectively over seven consecutive six months periods and a clear picture of each physician's prescription behaviour was obtained per half year and over the whole 42 months.

Longitudinal changes in prescription. In order to evaluate the longitudinal changes in preference for the prescription of certain drugs, the percentage of prescriptions for each drug in its ATC-category in every half year period has 
been registered. The variation of this percentage from one period to another represents the changing preference for each drug. Calculating the coefficient of variation for the so obtained series of seven percentages of preference over the entire period of three and a half years, for each drug and physician, provides a measure for the varying prescription behaviour. A small value for the said coefficient of variation points to a consistent preference while larger values are connected with stronger varying preferences over the consecutive half year periods. A convenient survey of longitudinal changes in prescription of specified drugs was obtained by graphical presentation of preferences of each GP for prescription of specified drugs in consecutive half year periods (figs $4.1-7$, for each ATC-category; the GPs are indicated by numerals 1-7; the ATC-categories are indicated by characters viz. $N$ for NSAIDs, $A C$ for $A C E$-inhibitors, $A D$ for antidepressants, $B$ for beta-blocking agents, $C a$ for calcium-channel blocking agents and $\mathrm{Ch}$ for cholesterol inhibitors).

Compliance with NHG-guidelines. The compliance with NHG-guidelines was checked by counting all prescriptions and calculating the percentage of prescriptions where these NHG-guidelines had been followed. In this way we determined the "global compliance', i.e the use of a drug which is recommended in the guidelines (64). We determined the number of prescriptions for the recommended drugs in relation to the total number of prescriptions. E.g. 265 prescriptions for diclofenac, 180 for ibuprofen and 88 for naproxen in one half year period out of a totall number of 626 prescriptions for NSAIDs give percentages of $42 \%, 29 \%$ and $14 \%$ viz. for diclofenac, ibuprofen and naproxen. These three drugs together being the NHG-recommended medication in the NSAID category so produce a summarised compliance of $85 \%$.

Regional "prescription density". Numbers of prescriptions have been related to numbers of registered patients in the R-region by calculating the "prescription density" (numbers of prescriptions per 100 patients per 42 months) for each ATC-category and overall. Adjustments for different age distributions were made by indirect standardisation taking the total population of the Netherlands as a standard.

Data processing. Data in tables and graphical presentations are presented on prescription policy per physician, per drug and category of drugs and per six months period and over the whole 42 months period. Comparisons in numbers and percentages are given concerning both the actual situation in any six months period and on longitudinal changes. Moreover, the compliance of each physician with NHG-recommended guidelines for treatment is registered.

Differences between proportions were statistically tested with the chi-square test 
for $k \times z$ tables, using a two sided significance level of $5 \%$. The variability of prescription preferences over the seven consecutive half year periods was analysed using coefficients of variation.

\section{Results}

General prescription behaviour. A total number of 41,131 prescriptions covering the six selected ATC-categories in three and a half years were retrospectively collected from the central pharmacy. We observed that all physicians prescribed different drugs in each category even within a relatively short period of six months. Observed over the total seven consecutive half year periods the variation in selection of chemical entities is quite considerable. From a total overall number of 77 available drugs in all six categories the number of selected different chemical entities varied per physician from 48 to 67 which means that from $62 \%-87 \%$ of all the drugs on the market in these ATC-categories have been prescribed. However, each individual made his personal selection of drugs. Differences between individual selections were noted, especially of 'drugs of personal preference' which were prescribed in at least $10 \%$ of cases and often much more. A considerable number of drugs appeared never to be selected for this purpose so that the number of drugs of personal preference which were used during three and a half years varied between physicians from 22 to 29 drugs, i.e. $29 \%-38 \%$ of all drugs available in the six ATC-categories. Statistically significant variation in prescription between physicians was registered for the category of anti-depressants and for the combination of all categories (table 4.2).

A detailed survey of prescriptions in different ATC-categories is presented in tables 4.3.a-f. It appeared that in all categories $88 \%-98 \%$ (weighted means) of all prescriptions was covered by the combined 'drugs of personal preference'. The highest score $(98 \%)$ was registered for cholesterol synthesis inhibitors. The categories containing a larger number of different interchangeable drugs for selection scored lower, but nevertheless at least $88 \%$ viz. $89 \%$ of prescriptions in the large categories of anti-depressants and beta-blocking agents were covered by drugs of personal preference.

In many categories the individual GPs prescribed a wide variety of drugs. In the largest collection, 16368 prescriptions for NSAIDs in 42 months, differences between individual GPs ranged from 11-15 drugs out of an available number of 16. As expected, the number of drugs of personal preference varied less and ranged from 4-6 different drugs which were prescribed for $89 \%-93 \%$ of all 
prescriptions (table 4.3.a).

The widest selected range was noted in the category of anti-depressants. The numbers of different drugs for prescription varied between GPs from 11-20 out of an available number of 20 drugs. Nevertheless, the numbers of different drugs of personal preference still ranged from 4-7 (table 4.3.c). Small numbers of drugs of personal preference, 2-4, were especially registered for calciumchannel blocking agents although a wide spectrum of 11 drugs was available (table 4.3.e).

Influence of NHG-guidelines. Different influences of NHG-guidelines were observed between GPs in every ATC-category and between these categories as such. Similar patterns of differing preferences were observed for the prescription of medication in all categories. For each general practitioner the total numbers of prescriptions in each category and the numbers of prescriptions following the NHG-guidelines were determined. The compliance was expressed as the percentage of prescriptions following the guidelines vs. the total number of prescriptions. For each ATC-category weighted means were calculated. Significant variation between drugs in percentage agreement with NHG-guidelines was observed (table 4.4).

This procedure was illustrated by a detailed observation concerning 16,368 prescriptions for NSAIDs. The NHG recommended drugs diclofenac, ibuprofen and naproxen were always registered as drugs of personal preference although with many other ones (table 4.3.a). Within the group of NHG-recommended drugs, however, remarkable differences were noted between preferences of individual physicians, e.g. preference for diclofenac varied from $17-44 \%$, ibuprofen $15-38 \%$ and naproxen $6-46 \%$. Nonetheless, from the combined percentages of prescriptions in compliance with NHG-guidelines for recommended drugs in the NSAID category it appeared that all physicians prescribed those in $64 \%$ to $86 \%$ of all cases. Inter-doctor variation in percentage of agreement with NHG-guidelines appeared to be significantly beyond chance (table 4.5). A significant although not complete adherence to the NHG-guidelines was thus observed. On average the guidelines for prescription of NSAIDs were followed by the general practitioners in $79 \%$ (weighted mean) of a grand total of 16,368 prescriptions.

Longitudinal changes of prescription. In general in the prescription policy of each individual physician gradual changes from each half year period to the next one were retrospectively observed over the full 42 months period.

The course of prescription of NSAIDs by each individual GP in consecutive half 
year periods is illustrated in figures 4.1.N -3.7.N. Most physicians prescribed preferably the NHG-recommended drugs diclofenac (figs. 4.2-7.N), ibuprofen (figs. $4.2,4,5,6 . \mathrm{N}$ ) and naproxen (figs. $4.2,4,5 . \mathrm{N}$ ). Although these drugs were selected in $79 \%$ of the total number of prescriptions, no really steady prescription behaviour was observed. Both steadily growing (ibuprofen figs. 4.1,2.N and diclofenac figs. 4.4,7.N) as well as steadily decreasing preferences (diclofenac figs. 4.2,3.N and naproxen figs. 4.1,4.N) have been registered over a longer period. It also happened that a long growing preference turned to decrease in the end, e.g. ibuprofen (fig. 4.2.N). Finally a rather consistent prescription of a wide variety of NSAIDs was seen as well (figs. 4.4.N). Some drugs apparently were prescribed during shorter periods and abandoned afterwards (piroxicam, fig. 4.3.N; nabumetone, fig. 4.7.N; meloxicam, fig. $4.1 \mathrm{~N}$ and fig. $4.2 \mathrm{~N}$ ) suggesting trial and error prescription policy.

In the category of ACE-inhibitors most GPs demonstrated a rather steady prescription behaviour for a wide spectrum of drugs. Small numbers of possibly intuitive prescriptions were noted as well, e.g. for quinapril, ramipril and trandolapril (figs. 4.1,3,4,6.AC). However, deliberate longitudinal changes were also observed, e.g. GPs nr. 2, 4,6 and 7 increasingly prescribed fosinopril, often simultaneously decreasing captopril prescriptions (figs. 4.2,4,6,7.AC).

In the category of anti-depressants the largest number of different chemical entities was prescribed by all GPs. Nevertheless, some often increasing preferences were registered for fluoxetine, paroxetine and fluvoxamine (figs. 4.1,37.AD). Remarkably increasing total numbers of prescriptions were observed in this category.

Increasing numbers of prescriptions were also registered for beta-blocking agents in some practices (figs. $4.5,7 . B$ ). Especially metoprolol appeared to be the drug of choice (figs. 4.1,4-6.B), sometimes with atenolol (figs. 4.2,7.B).

A steady prescription behaviour was generally noted for calcium-channel blocking agents. A certain competition between prescriptions for the most prescribed drugs nifedipine and amlodipine was observed (figs. 4.1,3,4,6,7.Ca).

A similar pattern was registered for the prescription of cholesterol inhibitors. Evidently simvastatin was the drug of choice (figs. $4.1-3,5,7 . \mathrm{Ch}$ ) although some GPs demonstrated a growing interest for pravastatin (figs. 4.4,6,7.Ch). Rising and declining interest for atorvastatin was equally observed (figs. 4.3-5. Ch).

A numerical approach for the evaluation of the degree of longitudinal changes in prescription policy for any drug in a certain category was realised by counting the varying numbers of prescriptions for each specific drug in its category during 
consecutive half year periods. Determination of the mean value with its coefficient of variation of the so obtained series of seven quantities over the total period of 42 months provides data on the degree of changes of selection. Calcullations have been made for the varying degrees of prescription of drugs of personal preference in all categories (table 4.6). A small coefficient of variation represents a prescription behaviour with only minor changes from one half year to the other meaning a consistent preference for prescription of the concerned drug. This was observed e.g. for the prescription of diclofenac by GPs $\mathrm{nr} .1,2,5-$ , 6 and 7 . Stronger longitudinal changes are represented by larger coefficients of variation such as e.g. the prescription of meloxicam by GPs nr. 2 and 3 in the NSAID-category. Similar patterns have been observed in the other ATC-categories.

Regional prescription density. The number of prescriptions per ATC-category and per 100 patients in 42 months was registered (table 4.7). It appeared that the largest majority of prescriptions had been written for the relatively unspecific category of NSAIDs followed by $\beta$-blocking agents, anti-depressive drugs and ACE-inhibitors. The smallest proportions were for Ca-channel blocking agents and cholesterol synthesis inhibitors. For comparative purposes a correction for the relatively high proportion of elderly patients in the R-region was made using available data on age distribution on a national scale (132). Adjusting the total number of 215.5 prescriptions per 100 patients to national means reduced this figure to 180.6 prescriptions / 100 patients / 42 months.

\section{Discussion}

The participating physicians have been selected retrospectively on the criterion that each one of them provided at least a sufficient number of prescriptions in every ATC-category during the period of investigation. Moreover, the practices of these physicians have many points in common and are similar as far as the population of patients in this urban area is concerned. A common aspect is also that all prescriptions were processed and have been stored in the administrative computer system of the central pharmacy.

In order to come to generalized conclusions the study should preferably include large numbers of data. This is why we selected the indicated categories of often prescribed drugs (table 4.1). Differentiation between interchangeable drugs in each category has been investigated not only during six months but especially over a period of three and a half years. By data collection over consecutive six months periods the influence of short term changes was avoided so that longitu- 
dinal changes in prescription could be studied.

The longitudinal prescription behaviour of each physician showed varying preferences from each half year period compared to the next one. This was demonstrated by quantitative comparison of numbers of prescriptions for specific drugs in each category per half year. Varying preferences between GPs were demonstrated (table 4.2).

From the collected data it is clear that all physicians used a variety of drugs even in the same category (tables 3.3.a-f). Cumulation of data led to a great number of different chemical entities selected in every category of drugs. No great differences in behaviour between the selected family practices were detected. Generally selection led to a broad spectrum of prescribed drugs, however, varying from one practice to another. From the difference in prescription patterns it could also be concluded that there had been little mutual influence between practices and no strong common influence from e.g. prescription policies of hospital consultants or repeat prescriptions.

Similar policies can be noted for the prescription of 'drugs of personal preference', i.e. prescribed in more than $10 \%$ of cases. Some authors (210) suggest that the number of drugs accounting for $90 \%$ of drug utilisation (designated DU90\%) may serve as an indicator of the quality of drug prescribing. Although this is a possibility, the mere counting of drugs gives only partial information on changing prescription behaviour. We agree that improved prescription behaviour is often illustrated by deliberate selection from a reduced spectrum of available chemical entities. Indeed, a decreased DU90\% reveals selection from a smaller number of drugs but no information is given about the selection of the 'drug of choice', which can be changing based on e.g. therapeutic evidence. Therefore we preferred to provide an example of the full picture of the development of the selection process in the course of time (figs. 4.1-7.N/AC/AD/B/Ca/Ch). We observed that the choice of drugs of personal preference was variable and actually never led to consistent prescription policy such as observed with the NHG-advised drugs. It could be concluded that the introduction of new drugs in a category often insufficiently convinced the prescriber of real therapeutic advantages or better practical applicability. Again, the accumulation of evidence based knowledge on advised medication could be a valuable contribution to consistent prescription which is supposed to enhance personal experience and expertise.

No clear evidence for external influences was detected. However, the exception was the apparent although not consistent influence of NHG-guidelines which 
were followed to a changing extent. All physicians displayed a certain although varying preference for the medication policy as advised in the NHG guidelines thus actually somewhat reducing the variety in their prescriptions. This preference for NHG-recommended drugs varied from an average of only $28 \%$ for antidepressants to $84 \%$ for cholesterol inhibitors (table 4.4). Evidently the publication of nationally agreed prescription guidelines sometimes happened to go in line with personal preferences (e.g. cholesterol inhibitors) and sometimes not (e.g. anti-depressants) which was also registered elsewhere (64). When they do, it leads to a slightly narrower prescription spectrum of drugs in a certain category. When they do not a wide prescription spectrum is seen. It is worth considering that the use of guidelines can be greatly facilitated by computer processing of prescriptions from a limited formulary. Again, we emphasize that we studied global compliance (64). The reason is that in the Netherlands it is common practice that the diagnosis is not mentioned on the prescription. However, the discussion on this subject is continuing and will not be over soon. As the set-up of our study was meant to be easy to be copies in everyday practice, we restricted our judgement to global compliance.

Longitudinally strongly changing preferences over three and a half years for certain chemical entities have been observed, demonstrated by large coefficients of variation (table 5 ). In some cases a growing preference for a certain drug was observed (e.g. ibuprofen, fig. 4.1) and sometimes a changing (e.g. naproxen, fig. 4.4) or decreasing preference was noted (e.g. naproxen fig. 4.1). However, also rather consistent preferences were seen with little longitudinal changes c.q. small coefficients of variation (e.g. simvastatin, table 5). It appeared that the prescription of 'older' (long known) drugs is subject to gradual changes while newly developed drugs were liable to rapidly changing preferences. This was true for the whole group of physicians and might be a demonstration of a 'trial and error' policy regarding newly introduced drugs which is in line with other studies $(116,103)$.

The increase of experience by consistent drug therapy is regarded as good medical practice (35). Changing from opinion based practice to evidence based medicine will doubtlessly contribute to improved quality of treatment (156). The observed prescription policy of all physicians had elements of this aspect but should be strengthened by more strict regulations such as the introduction of electronic formularia based on the NHG-guidelines or other formularia. Although the relatively large number of prescriptions in the R-region could partly be attributed to a high proportion of elderly patients, formulary prescription could 
lead to a more restricted prescription policy e.g. for NSAIDs and anti-depressants which together represent more than $50 \%$ of all prescriptions (table 4.7 ), possibly for rather unspecific indications. Moreover, active participation in structured pharmaco-therapeutic audit conferences of prescribing physicians with dispensing pharmacists should be encouraged and perhaps even made obligatory.

In summary we conclude that, based on different personal preferences, physicians in general practice prescribe a wide variety of chemical entities within each category of interchangeable drugs. Moreover, every individual GP had his own limited list of 'drugs of personal preference' in each ATC-category. These drugs of personal preference might well be supposed to represent the "drugs of choice" for optimal treatment of the disease for which they had been prescribed. That the selection of these drugs differed between physicians can not easily be explained and clearly accentuates the need for evidence based medicine as a guideline for the selection of drugs of choice. Existing advised standards for drug therapy (NHG-guidelines) are often followed to a limited extent. Inconsistent prescription policy is demonstrated by longitudinal changes in preferences for many drugs. We recommend that the selection in an ATC-category be limited in order to increase the accumulation of medicine based evidence on the use of these drugs. Also the compliance to NHG-guidelines must be stimulated in order to develop a common and optimal drug therapy based not only on personal experience but also on evidence based medical science. Pharmaco-therapeutic audit conferences should be obligatory and active to develop formularies based on medical scientific literature and cumulated experience of the participants. Maintenance and continuous evaluation by retrospective study of prescription data will keep these necessary formularies up to date with the state of the art.

References: cf. general reference list (ch. II). 
table 4.1. ATC-categories with indication of drugs listed in the NHG-guidelines.

\begin{tabular}{|c|c|c|c|c|c|}
\hline NSAIDS & $\begin{array}{l}\text { ACE- } \\
\text { inhibitors }\end{array}$ & $\begin{array}{l}\text { anti- } \\
\text { depressants }\end{array}$ & $\begin{array}{l}\text { beta-blocking } \\
\text { agents }\end{array}$ & $\begin{array}{l}\text { Ca-channe } \\
\text { block. agen- }\end{array}$ & $\begin{array}{l}\text { chol. } \\
\text { inhibitors }\end{array}$ \\
\hline category M01A & CO9A & NOGA & C07A & $\mathrm{COBC}$ & C10AA \\
\hline \multirow{2}{*}{\multicolumn{6}{|c|}{ NHG-guidelines }} \\
\hline & & & & & \\
\hline diclofenac & captopril & amitriptyline & ateniolol & nifedipine & simvastatin \\
\hline buprofen & enalapril & imipramine & metoprola & nitrendipine & pravastatin \\
\hline naproxen & & fluvoxamine & & & \\
\hline \multicolumn{6}{|l|}{ complete ATC-list } \\
\hline aceclofenac & benazepril & amitriptyline & acebutolol & amlodipine & atorvastatin \\
\hline azapropazone & captopril & citalopram & alprenolol & felodipine & cerivastatin \\
\hline diclof/misopr. & cilazapril & clomipramine & atenolol & irsadipine & fluvastatin \\
\hline diclofenac & enalapril & desipramine & betaxolol & lacidipine & pravastatin \\
\hline fenylbutazone & fosinopril & dosulepine & bisoprolol & lercanidipine \# & simvastatin \\
\hline flurbiprofen & lisinopril & doxepine & carvedilol & mibefradil \#* & \\
\hline ibuprofen & perindopril & fluoxetine & celiprolol & nicardipine & \\
\hline indometacin & quinapril & fluvoxamine & Iabetalol & nifedipine & \\
\hline ketoprofen & ramipril & impramine & metoprolol & nimodipine & \\
\hline meloxicam & trandolapril & maprotiline & nebivolol & nisoldipine \# & \\
\hline nabumetone & & mianserine & oxprenolol & nitrendipine & \\
\hline naproxen & & mirtazapine & pindolol & & \\
\hline piroxicam & & moclobemide & propanolol & & \\
\hline tenoxicam & & nefazodone & sotalol & & \\
\hline tiaprof.acid & & nortriptyline & tertatolol & & \\
\hline tolfenamic acid & & paroxetine & & & \\
\hline & & sertraline & & & \\
\hline & & trazodone & & & \\
\hline & & trimipramine & & & \\
\hline & & venlafaxine & & & \\
\hline $\mathrm{nr}$. of drugs & 10 & 20 & 15 & 11 & \\
\hline
\end{tabular}

\# introduced as new drug during the study

" withdrawn from the market on account of interactions 
table 4.2. Ranges of variety in prescription between GPs in the R-group per ATC-category of drugs.

Number of different drugs overall and number of different drugs of personal preference prescribed in all consecutive six months periods.

\begin{tabular}{|l|l|l|l|}
\hline category (ATC-code) & $\begin{array}{l}\text { total nr. of } \\
\text { available } \\
\text { drugs }\end{array}$ & $\begin{array}{l}\text { range of differ- } \\
\text { ent drugs over- } \\
\text { all }\end{array}$ & $\begin{array}{l}\text { range of different } \\
\text { drugs of personal } \\
\text { preference }\end{array}$ \\
\hline NSAID's (MO1A) & 16 & $11-15$ & $4-5$ \\
\hline ACE-inhibitors (C09A) & 10 & $6-8$ & $3-7$ \\
\hline antidepressants * (N06A) & 20 & $11-20$ & $4-7$ \\
\hline B-blocking agents (CO7A) & 15 & $8-10$ & $3-5$ \\
\hline $\begin{array}{l}\text { Ca-channel blocking agents } \\
\text { (CO8C) }\end{array}$ & 11 & $6-10$ & $2-4$ \\
\hline cholesterol inhib. (C10AA) & 5 & $4-5$ & $2-4$ \\
\hline all drugs * & 77 & $48-67$ & $22-29$ \\
\hline
\end{tabular}

* variation in prescription between physicians significantly beyond chance $(p<0.05$; chi-square test) 
table 4.3.a. NSAIDs prescribed by individual physicians in a period of $\mathbf{4 2}$ months.

Varying selection of drugs of personal preference (prescriptions $>10 \%$ ) with combined percentage prescriptions for these drugs and selection of other drugs with percentage prescriptions;

number of selected different drugs with total number of prescriptions.

\begin{tabular}{|l|l|l||l|l||c|c|}
\hline $\begin{array}{l}\text { R- } \\
\text { group }\end{array}$ & $\begin{array}{l}\text { personal } \\
\text { preference }\end{array}$ & $\begin{array}{l}\text { percent } \\
\text { prescr. }\end{array}$ & other drugs & $\begin{array}{l}\text { percent } \\
\text { prescr. }\end{array}$ & $\begin{array}{l}\text { nr. diff. } \\
\text { drugs }\end{array}$ & $\begin{array}{l}\text { total nr. } \\
\text { prescr. }\end{array}$ \\
\hline GP 1 & $\begin{array}{l}1,2,3, \\
6,8\end{array}$ & $93 \%$ & $\begin{array}{l}5,9,11,12,13, \\
15,16\end{array}$ & $7 \%$ & 12 & 2137 \\
\hline GP 2 & $\begin{array}{l}1,2,3, \\
5,8\end{array}$ & $89 \%$ & $\begin{array}{l}6,9,11,12,13, \\
15,16\end{array}$ & $11 \%$ & 12 & 2050 \\
\hline GP 3 & $\begin{array}{l}1,2,3, \\
6,8,15\end{array}$ & $92 \%$ & $\begin{array}{l}5,7,9,10,11, \\
13,16\end{array}$ & $8 \%$ & 13 & 1793 \\
\hline GP 4 & $\begin{array}{l}1,2,3, \\
5\end{array}$ & $91 \%$ & $\begin{array}{l}6,7,8,9,11,12, \\
13,15,16\end{array}$ & $9 \%$ & 13 & 4275 \\
\hline GP 5 & $\begin{array}{l}1,2,3, \\
13,16\end{array}$ & $91 \%$ & $\begin{array}{l}5,6,8,11,12, \\
15\end{array}$ & $9 \%$ & 12 & 1608 \\
\hline GP 6 & $\begin{array}{l}1,2,3, \\
5,6\end{array}$ & $91 \%$ & $\begin{array}{l}4,7,8,9,11,12, \\
13,14,15,16\end{array}$ & $9 \%$ & 15 & 3161 \\
\hline GP 7 & $\begin{array}{l}1,2,3, \\
6,9,15\end{array}$ & $92 \%$ & $5,8,11,13,16$ & $8 \%$ & 11 & 1345 \\
\hline means & & $92 \%$ & & $8 \%$ & & t. 16368 \\
\hline
\end{tabular}

legend drug identification numbers:

NHG-recommended drugs: 1-diclofenac; 2-ibuprofen; 3-naproxen.

other drugs: 4-aceclofenac; 5-diclofenac/misoprostol; 6-piroxicam; 7 -tenoxicam;

8-meloxicam; 9-indometacin; 10-sulindac; 11-ketoprofen;

12-flurbiprofen; 13-tiaprofenic acid; 14-tolfenaminic acid;

15-nabumetone; 16-azapropazone. 
table 4.3.b. ACE-inhibitors prescribed by individual physicians in a period of $\mathbf{4 2}$ months.

Varying selection of drugs of personal preference and other drugs.

\begin{tabular}{|l|l|l|l|l|l|l|}
\hline $\begin{array}{l}\text { R- } \\
\text { group }\end{array}$ & $\begin{array}{l}\text { personal pref- } \\
\text { erence }\end{array}$ & $\begin{array}{l}\text { percent. } \\
\text { prescr. }\end{array}$ & other drugs & $\begin{array}{l}\text { per- } \\
\text { cent. } \\
\text { prescr. }\end{array}$ & $\begin{array}{l}\text { nr. diff. } \\
\text { drugs }\end{array}$ & $\begin{array}{l}\text { total nr. } \\
\text { prescr. }\end{array}$ \\
\hline GP 1 & $\begin{array}{l}1,2,3,4,5,6, \\
7\end{array}$ & $98 \%$ & 8 & $2 \%$ & 8 & 458 \\
\hline 2 & $1,2,4,5,6$ & $96 \%$ & 3,8 & $4 \%$ & 7 & 725 \\
\hline 3 & $1,2,3,4$ & $98 \%$ & $5,6,7,8$ & $2 \%$ & 8 & 567 \\
\hline 4 & $1,2,3,4,5,6$ & $99 \%$ & 7,8 & $1 \%$ & 8 & 1654 \\
\hline 5 & $1,2,3,4$ & $92 \%$ & 6,8 & $8 \%$ & 6 & 369 \\
\hline 6 & $1,2,3,4,5,6$ & $97 \%$ & 7,8 & $3 \%$ & 8 & 1053 \\
\hline 7 & $1,2,6$ & $89 \%$ & $3,4,5$ & $11 \%$ & 6 & 815 \\
\hline means & & $96 \%$ & & $4 \%$ & & t. 5641 \\
\hline
\end{tabular}

legend drug identification numbers:

NHG-recommended drugs: 1-captopril; 2-enalapril

other drugs: 3-lisinopril; 4-perindopril; 5-ramipril; 6-fosinopril; 7-trandolapril;

8-quinapril 
table 4.3.c. Anti-depressants prescribed by individual physicians in a period of $\mathbf{4 2}$ months.

Varying selection of drugs of personal preference and other drugs.

\begin{tabular}{|l|l|l|l|l|l|l|}
\hline $\begin{array}{l}\text { R- } \\
\text { group }\end{array}$ & $\begin{array}{l}\text { personal } \\
\text { preference }\end{array}$ & $\begin{array}{l}\text { percent. } \\
\text { prescr. }\end{array}$ & other drugs & $\begin{array}{l}\text { percent. } \\
\text { prescr. }\end{array}$ & $\begin{array}{l}\text { nr. diff. } \\
\text { drugs }\end{array}$ & $\begin{array}{l}\text { total nr. } \\
\text { prescr. }\end{array}$ \\
\hline GP 1 & $1,3,4,5,1$, & $94 \%$ & $6,9,12,17,20$ & $6 \%$ & 11 & 376 \\
\hline 2 & $\begin{array}{l}1,3,4,9,11,1- \\
2,21\end{array}$ & $84 \%$ & $\begin{array}{l}5,6,13,14,16, \\
17\end{array}$ & $16 \%$ & 13 & 532 \\
\hline 3 & $1,3,4,14$ & $87 \%$ & $\begin{array}{l}2,5,6,11,12, \\
13,16,20\end{array}$ & $13 \%$ & 12 & 835 \\
\hline 4 & $\begin{array}{l}1,4,11,12, \\
14,21\end{array}$ & $88 \%$ & $\begin{array}{l}2,3,5,6,7,9, \\
10,13,15,17, \\
18,19,20\end{array}$ & $12 \%$ & 19 & 1394 \\
\hline 5 & $1,3,4,11,21$ & $96 \%$ & $\begin{array}{l}5,6,12,14,16, \\
20\end{array}$ & $4 \%$ & 11 & 483 \\
\hline 6 & $1,3,4,11,12$, & $85 \%$ & $\begin{array}{l}2,5,6,7,9,10, \\
13,14,15,16, \\
17,18,19,20\end{array}$ & $15 \%$ & 20 & 1512 \\
\hline 7 & $2,3,4,5,11$, & $87 \%$ & $\begin{array}{l}1,7,9,13,14, \\
17\end{array}$ & $13 \%$ & 13 & 629 \\
\hline means & 12,21 & $88 \%$ & & $12 \%$ & & t. 5761 \\
\hline
\end{tabular}

legend drug identification numbers:

NHG-recommended drugs: 1-amitriptyline; 2-imipramine; 3-fluvoxamine

other drugs: 4-paroxetine; 5-clomipramine; 6-moclobemide; 7-citalopram; 8-desipramine; 9-dasulepine; 10-doxepine; 11-fluoxetine; 12-maprotiline; 13-mianserine; 14-mirtazapine; 15-nefazodone; 16-nortryptiline; 17-sertraline; 18-trazodone; 19-trimipramine; 20-venlafaxine. 
table 4.3.d. Beta-blocking agents prescribed by individual physicians in a period of 42 months.

Varying selection of drugs of personal preference and other drugs.

\begin{tabular}{|l|l|l|l|l|l|c|}
\hline $\begin{array}{l}\text { R- } \\
\text { group }\end{array}$ & $\begin{array}{l}\text { personal } \\
\text { preference }\end{array}$ & $\begin{array}{l}\text { percent. } \\
\text { prescr. }\end{array}$ & other drugs & $\begin{array}{l}\text { percent. } \\
\text { prescr. }\end{array}$ & $\begin{array}{l}\text { nr. diff. } \\
\text { drugs }\end{array}$ & $\begin{array}{l}\text { total nr. } \\
\text { prescr. }\end{array}$ \\
\hline GP 1 & $\mathbf{1 , 2 , 1 4 , 1 5}$ & $87 \%$ & $3,7,8,9,10,12$ & $13 \%$ & 10 & 972 \\
\hline 2 & $\begin{array}{l}1,2,7,14, \\
15\end{array}$ & $94 \%$ & $9,10,12$ & $6 \%$ & 8 & 793 \\
\hline 3 & $2,7,14,15$ & $86 \%$ & $1,3,8,9,10,12$ & $14 \%$ & 10 & 738 \\
\hline 4 & $1,2,7,15$ & $89 \%$ & $4,8,9,10,12,13$ & $11 \%$ & 10 & 1961 \\
\hline 5 & $2,14,15$ & $88 \%$ & $\begin{array}{l}1,3,4,7,9,10, \\
12\end{array}$ & $12 \%$ & 10 & 738 \\
\hline 6 & $1,2,7,15$ & $87 \%$ & $4,8,9,10,12,13$ & $13 \%$ & 10 & 1191 \\
\hline 7 & $1,2,7,14$, & $95 \%$ & $4,11,13,15$ & $5 \%$ & 9 & 820 \\
\hline means & 15 & $89 \%$ & & $11 \%$ & & t. 7213 \\
\hline
\end{tabular}

legend drug identification numbers:

NHG-recommended drugs: 1-atenolol; 2-metoprolol other drugs: 3-pindolol; 4-acebutolol; 5-alprenolol; 6-betaxolol; 7-bisoprolol; 8-carvedilol" 9-celiprolol; 10-labetalol; 11-nebivolol; 12-oxprenolol; 13-propanolol; 14-sotalol; 15-tertatolol. 
table 4.3.e. Calcium-channel blocking agents prescribed by individual physicians in a period of $\mathbf{4 2}$ months.

Varying selection of drugs of personal preference and other drugs.

\begin{tabular}{|l|l|l|l|l|l|l|}
\hline $\begin{array}{l}\text { R- } \\
\text { group }\end{array}$ & $\begin{array}{l}\text { personal } \\
\text { preference }\end{array}$ & $\begin{array}{l}\text { percent. } \\
\text { prescr. }\end{array}$ & other drugs & $\begin{array}{l}\text { percent. } \\
\text { prescr. }\end{array}$ & $\begin{array}{l}\text { nr. diff. } \\
\text { drugs }\end{array}$ & $\begin{array}{l}\text { total } \\
\text { nr. } \\
\text { prescr. }\end{array}$ \\
\hline GP 1 & 1,2 & $88 \%$ & $4,5,7,10$ & $12 \%$ & 6 & 350 \\
\hline 2 & $1,2,3$ & $95 \%$ & 4,10 & $5 \%$ & 5 & 391 \\
\hline 3 & 1,2 & $83 \%$ & $3,4,5,6,10$ & $17 \%$ & 7 & 304 \\
\hline 4 & 1,2 & $82 \%$ & $\begin{array}{l}3,4,5,6,7,8, \\
10,11\end{array}$ & $18 \%$ & 10 & 883 \\
\hline 5 & $1,2,3,4$ & $93 \%$ & 5,10 & $7 \%$ & 6 & 328 \\
\hline 6 & $1,2,3$ & $89 \%$ & $4,5,6,7,8,10,11$ & $11 \%$ & 10 & 557 \\
\hline 7 & $1,2,3$ & $93 \%$ & $5,6,10$ & $7 \%$ & 6 & 376 \\
\hline means & & $88 \%$ & & $12 \%$ & & t. 3189 \\
\hline
\end{tabular}

legend drug identification numbers:

NHG-recommended drugs: 1-nifedipine

other drugs: 2-amlodipine; 3-felodipine; 4-isradipine; 5-lacidipine; 6-lercanidipine;

7-mibefradil; 8-nicardipine; 9-nimodipine; 10-nisoldipine; 11-nitrendipine. 
table 4.3.f. Cholesterol inhibitors prescribed by individual physicians in a period of $\mathbf{4 2}$ months.

Varying selection of drugs of personal preference and other drugs.

\begin{tabular}{|l|l|l|l|l|l|l|}
\hline $\begin{array}{l}\text { R- } \\
\text { group }\end{array}$ & $\begin{array}{l}\text { personal } \\
\text { prefer- } \\
\text { ence }\end{array}$ & $\begin{array}{l}\text { percent. } \\
\text { prescr. }\end{array}$ & $\begin{array}{l}\text { other } \\
\text { drugs }\end{array}$ & $\begin{array}{l}\text { percent. } \\
\text { prescr. }\end{array}$ & $\begin{array}{l}\text { nr. diff. } \\
\text { drugs }\end{array}$ & $\begin{array}{l}\text { total nr. } \\
\text { prescr. }\end{array}$ \\
\hline GP 1 & $1,2,4$ & $96 \%$ & 3 & $4 \%$ & 4 & 298 \\
\hline 2 & $1,2,3$ & $97 \%$ & 4,5 & $3 \%$ & 5 & 350 \\
\hline 3 & $1,2,4$ & $96 \%$ & 3,5 & $4 \%$ & 5 & 229 \\
\hline 4 & $1,2,3,4$ & $99 \%$ & 5 & $1 \%$ & 5 & 1059 \\
\hline 5 & $1,2,4$ & $99 \%$ & 3 & $1 \%$ & 4 & 233 \\
\hline 6 & $1,2,3,4$ & $99 \%$ & 5 & $1 \%$ & 5 & 483 \\
\hline 7 & 1,2, & $98 \%$ & 3,4 & $2 \%$ & 4 & 307 \\
\hline means & & $98 \%$ & & $2 \%$ & & t. 2959 \\
\hline
\end{tabular}

legend drug identification numbers:

NHG-recommended drugs: 1-simvastatin; 2-pravastatin other drugs: 3-fluvastatin; 4-atorvastatin; 5-cerivastatin 
table 4.4. Ranges of compliance of physiclans in the R-group for the prescription of NHG recommended drugs.

The percentage prescriptions for NHG recommended drugs (range between GPs and weighted means ) per ATC-category with the total number of prescriptions in 42 months have been registered.

\begin{tabular}{|l|l|l|l|}
\hline & $\%$ compliance range & weighted mean & total nr. prescr. \\
\hline NSAIDs & $64-86$ & 79 & 16368 \\
\hline ACE inhib. & $25-74$ & 41 & 5641 \\
\hline anti-depress. & $16-55$ & 28 & 5761 \\
\hline B-blocking agents & $37-70$ & 60 & 7213 \\
\hline $\begin{array}{l}\text { Ca-ch. blocking } \\
\text { agents }\end{array}$ & $38-65$ & 50 & 3189 \\
\hline chol. inhib. & $77-98$ & 84 & 2959 \\
\hline
\end{tabular}

table 4.5. Range of percentages of prescriptions for NHG recommended NSAIDs by physicians in the R-group in $\mathbf{4 2}$ months.

Total number 16368 prescriptions for NSAIDs.

\begin{tabular}{|c|c|c|c|}
\hline NSAID: & range $\%$ prescr. & mean $\%$ prescr. & range $\mathrm{nr}$. prescr. \\
\hline diclofenac & $17-44$ & 32 & $890-2305$ \\
\hline ibuprofen & $15-38$ & 25 & $614-1555$ \\
\hline naproxen & $6-46$ & 21 & $206-1650$ \\
\hline$\%$ NHG compliance & $64-86 \%$ & $79 \%$ & $10476-14076$ \\
\hline
\end{tabular}

* inter-doctor variation in percentage of agreement with NHG-guidelines significantly beyond chance ( $p<0.05$; chi-square test). 
table 4.6. Coefficients of variation concerning prescription of drugs of personal preference by GPs in the R-group over seven consecutive half year periods.

Ranges of cv's per drug and mean cv's per ATC-category (cf: Methods). (bold type: NHG-recommended drugs).

\begin{tabular}{|c|c|c|c|}
\hline \multirow{2}{*}{\multicolumn{2}{|c|}{ NSAIDS }} & & c.w. range \\
\hline & & \multicolumn{2}{|c|}{ BETA-BLOCKING AGENTS } \\
\hline diclofenac & $12-34$ & propranolol & $26-46$ \\
\hline diclof/misopr & $68-131$ & sotalol & $15-39$ \\
\hline piroxicam & $36-105$ & metoprolol & $6-15$ \\
\hline meloxicam & $106-219$ & atenolol & $11-25$ \\
\hline ibuprofen & $10-51$ & bisoprolol & $6-28$ \\
\hline naproxen & $15-55$ & mean of category & 22 \\
\hline tiaprofenic acid & 40 & & \\
\hline nabumetone & $72-123$ & & \\
\hline azapropazone & $0-51$ & & \\
\hline mean of category & 66 & & \\
\hline \multicolumn{2}{|l|}{ ACE-INHIBITORS } & \multicolumn{2}{|c|}{ CA-CHANNEL BLOCKING AGENTS } \\
\hline captopril & $22-34$ & amlodipine & $11-70$ \\
\hline enalapril & $8-26$ & felodipine & $25-51$ \\
\hline lisinopril & $24-90$ & isradipine & 52 \\
\hline perindopril & $17-67$ & nifedilipine & $5-29$ \\
\hline ramipril & $21-57$ & lercanidipine & 174 \\
\hline fosinopril & $49-126$ & mean of category & 62 \\
\hline trandolapril & 59 & & \\
\hline mean of category & 45 & & \\
\hline \multicolumn{2}{|l|}{ ANTI-DEPRESSANTS } & \multicolumn{2}{|c|}{\begin{tabular}{|l} 
CHOLESTEROL INHIBITORS \\
\end{tabular}} \\
\hline imipramine & 212 & simvastatin & $6-24$ \\
\hline clomipramine & $83-101$ & pravastatin & $9-49$ \\
\hline amitriptyline & $13-67$ & fluvastatin & $30-72$ \\
\hline nortryptiline & 265 & atorvastatin & $118-152$ \\
\hline dosulepine & 146 & mean of category & 54 \\
\hline maprotiline & $28-125$ & & \\
\hline fluoxetine & $20-66$ & & \\
\hline paroxetine & $27-79$ & & \\
\hline fluvoxamine & $28-68$ & & \\
\hline mirtazapine & $57-66$ & & \\
\hline venlafaxine & $22-95$ & & \\
\hline mean of category & 96 & & \\
\hline
\end{tabular}


table 4.7. Regional prescription density.

Total numbers of prescriptions with percentages per ATC-category during

42 months and numbers of prescriptions per 100 patients.

\begin{tabular}{|c|c|c|c|}
\hline & \multicolumn{3}{|c|}{$R$ - region: 19087 patients } \\
\hline & nr. prescriptions & $\begin{array}{l}\% \text { of total number } \\
\text { of prescriptions }\end{array}$ & $\begin{array}{l}\text { nr. of prescriptions } \\
\text { per } 100 \text { patients }\end{array}$ \\
\hline NSAIDS & 16368 & $40.5 \%$ & 85.7 \\
\hline ACE inhib. & 5641 & $14.0 \%$ & 29.5 \\
\hline $\begin{array}{l}\text { anti- } \\
\text { depress. }\end{array}$ & 5761 & $12.6 \%$ & 30.2 \\
\hline$\beta$-bl. agents & 7213 & $17.8 \%$ & 37.7 \\
\hline $\begin{array}{l}\text { Ca-ch. bl. } \\
\text { agents }\end{array}$ & 3189 & $7.8 \%$ & 16.7 \\
\hline $\begin{array}{l}\text { cholesterol } \\
\text { inhib. }\end{array}$ & 2959 & $7.3 \%$ & 15.5 \\
\hline $\begin{array}{l}\text { total (all } \\
\text { drugs) }\end{array}$ & 41131 & $100 \%$ & 215.5 \\
\hline
\end{tabular}


legends to the figures:

figs. 4.1.N-4.7.N

Prescriptions of NSAIDs.

Numbers of prescriptions by individual physicians GP1 - GP7 for specific NSAIDs in seven consecutive six months periods.

figs. 4.1.AC - 4.7.AC

\section{Prescriptions of ACE-inhibitors.}

Numbers of prescriptions by individual physicians GP1 - GP7 for specific ACEinhibitors in seven consecutive six months periods.

figs. 4.1.AD - 4.7.AD

Prescriptions of anti-depressants.

Numbers of prescriptions by individual physicians GP1 - GP7 for specific antidepressants in seven consecutive six months periods.

figs. 4.1.B - 4.7.B

Prescriptions of beta-blocking agents.

Numbers of prescriptions by individual physicians GP1 - GP7 for specific betablocking agents in seven consecutive six months periods.

figs. 4.1.Ca - 4.7.Ca

Prescriptions of calcium-channel blocking agents.

Numbers of prescriptions by individual physicians GP1 - GP7 for specific calcium-channel blocking agents in seven consecutive six months periods.

figs. 4.1.Ch - 4.7.Ch

\section{Prescriptions of cholesterol inhibitors.}

Numbers of prescriptions by individual physicians GP1 - GP7 for specific cholesterol inhibitors in seven consecutive six months periods. 


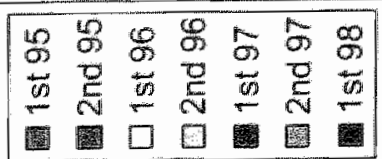

$z \frac{x}{N}$
$y 0$
0

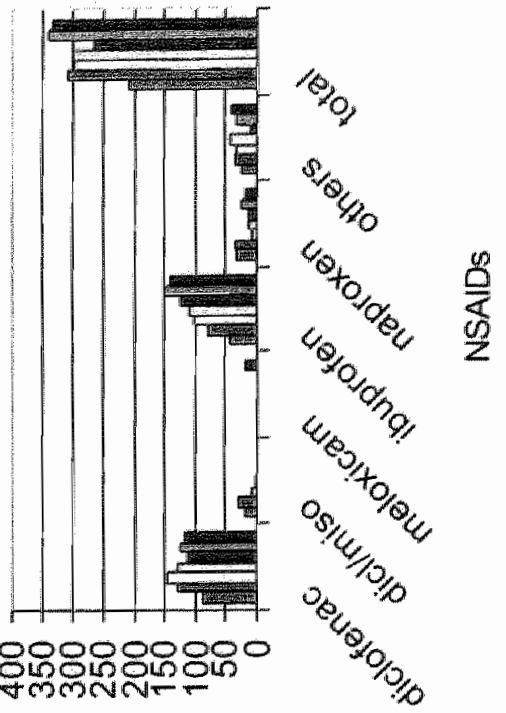

suonduosesd to jequnu

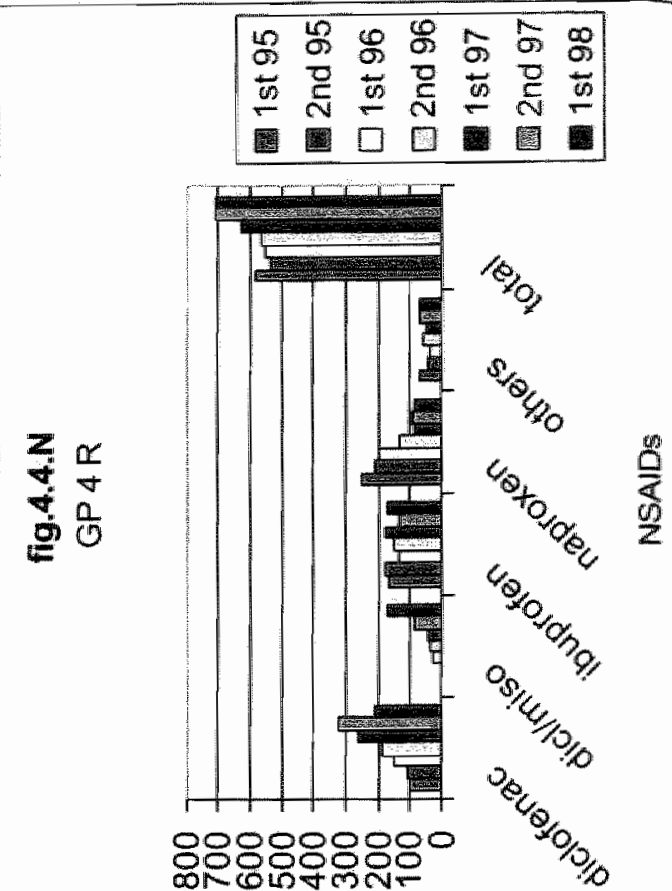

suond usesd fo səqunu $z \alpha$
$\dot{z} \frac{a}{0}$
$\dot{v}$
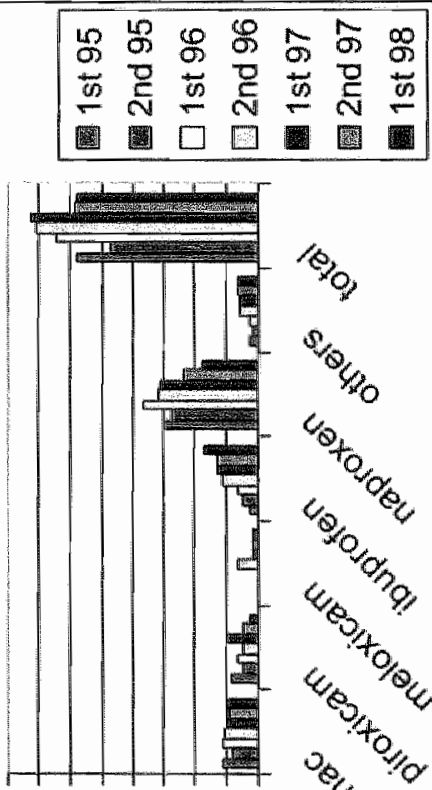

00000000

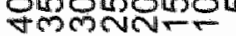<smiles>[C-]#[Co]</smiles><smiles></smiles>

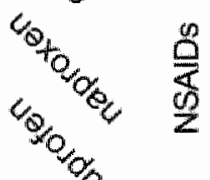<smiles>C1=C[C@H]2CC[C@H]1C2</smiles>

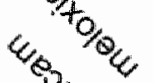

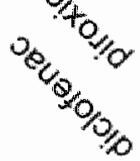

suonduldosesd to Jequnu

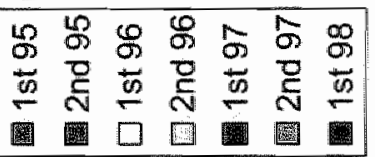

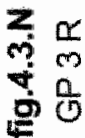

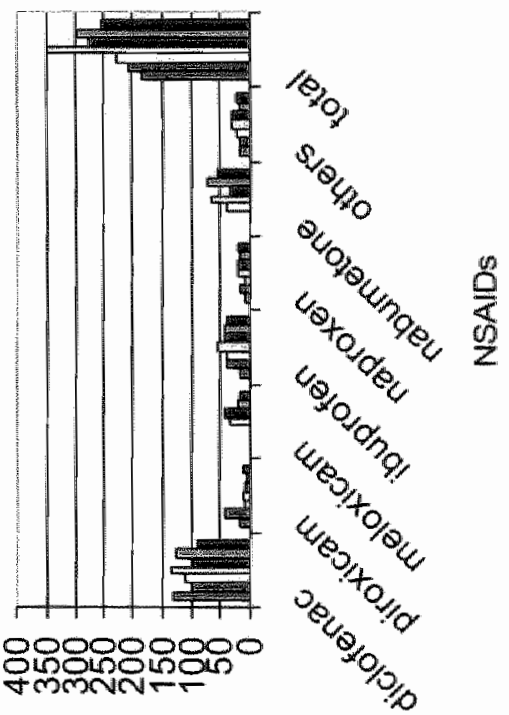

suondlussaıd jo jaqunu 

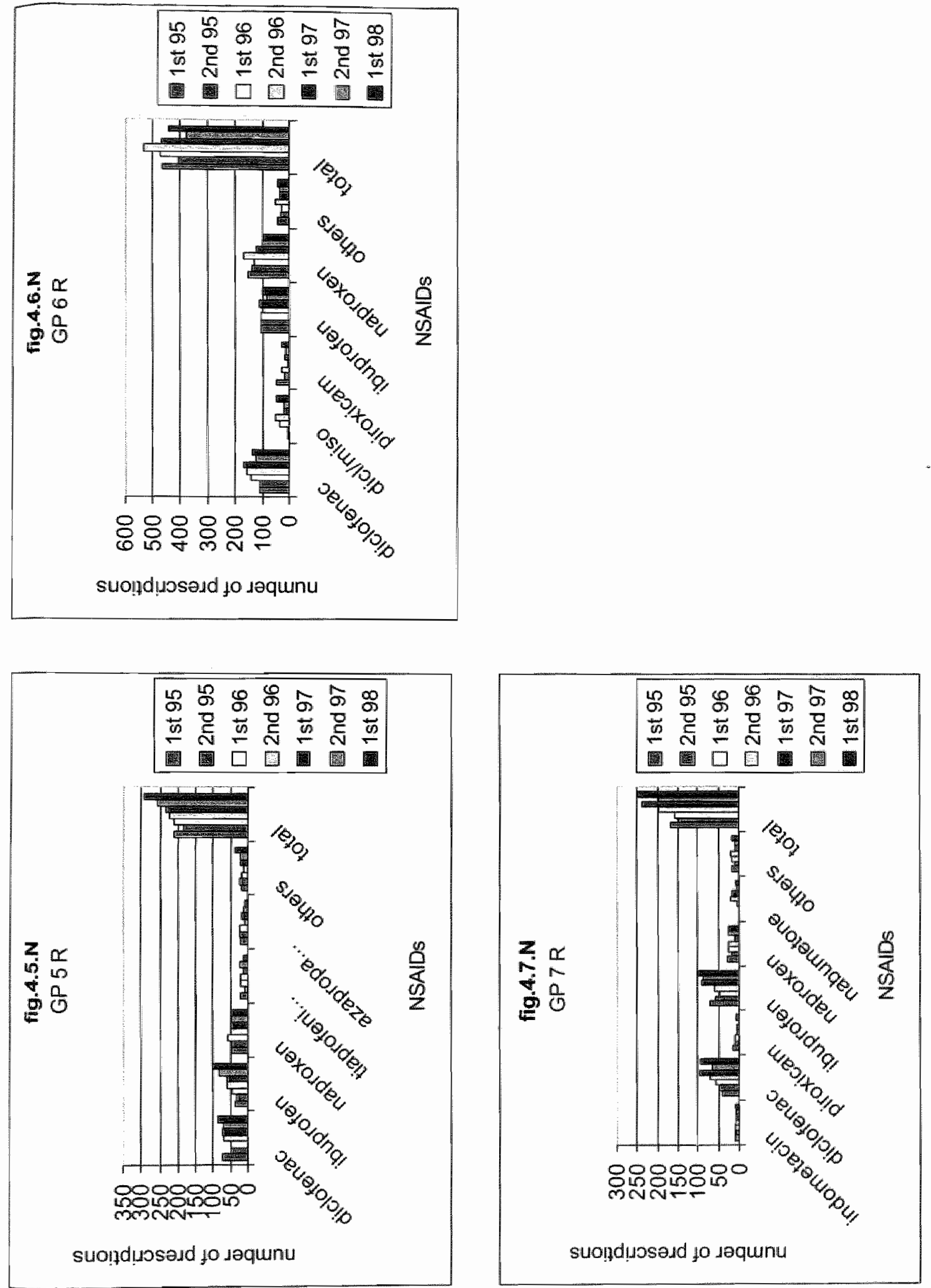

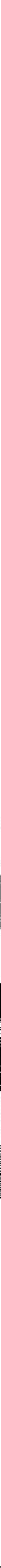

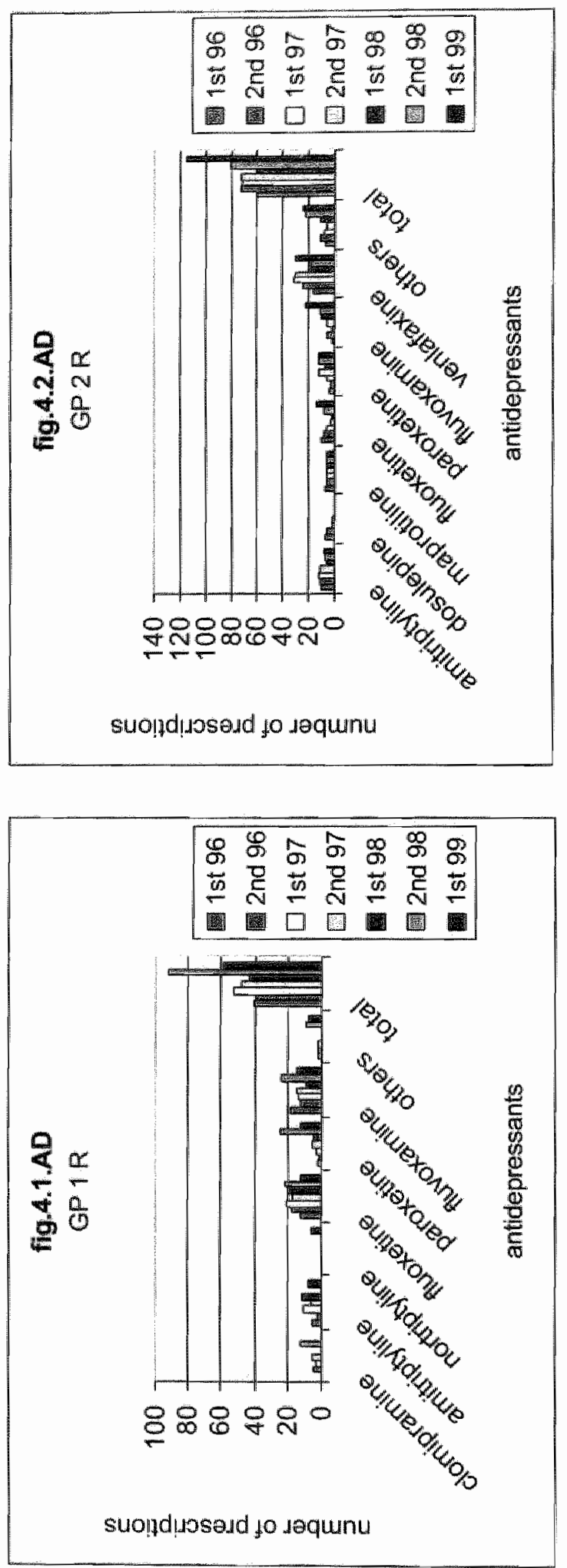
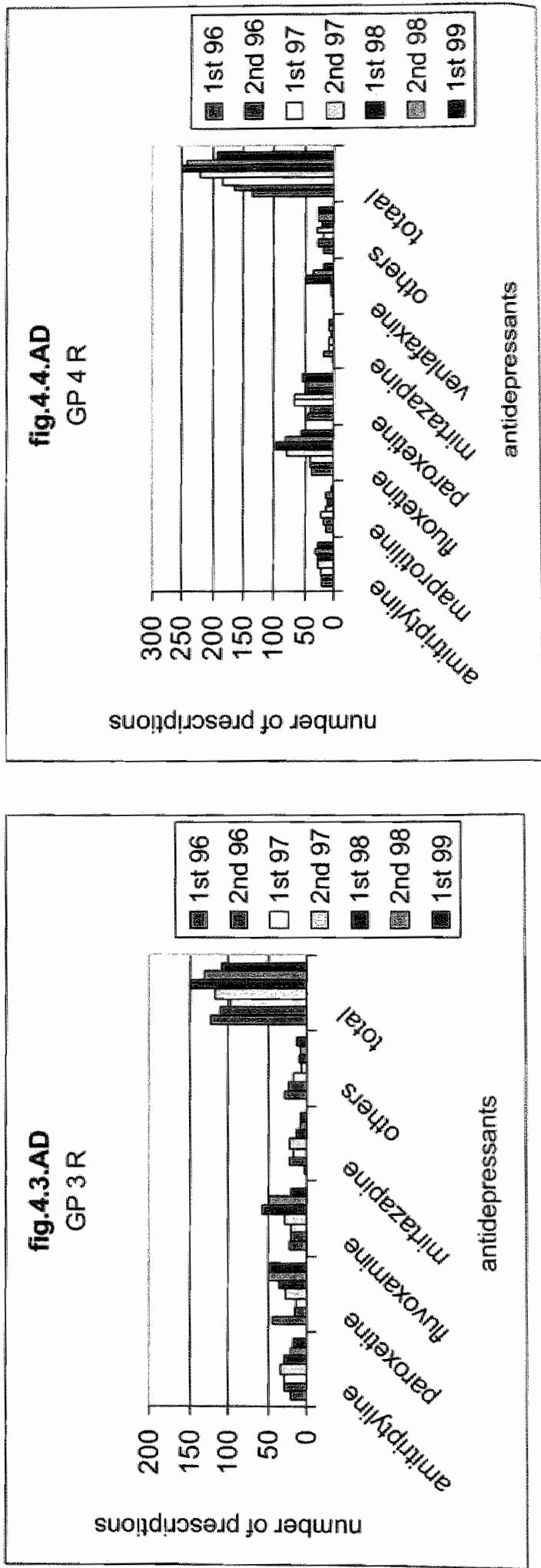

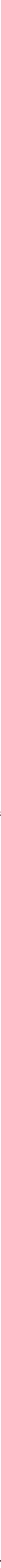

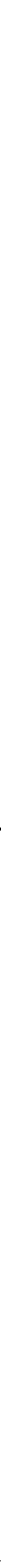

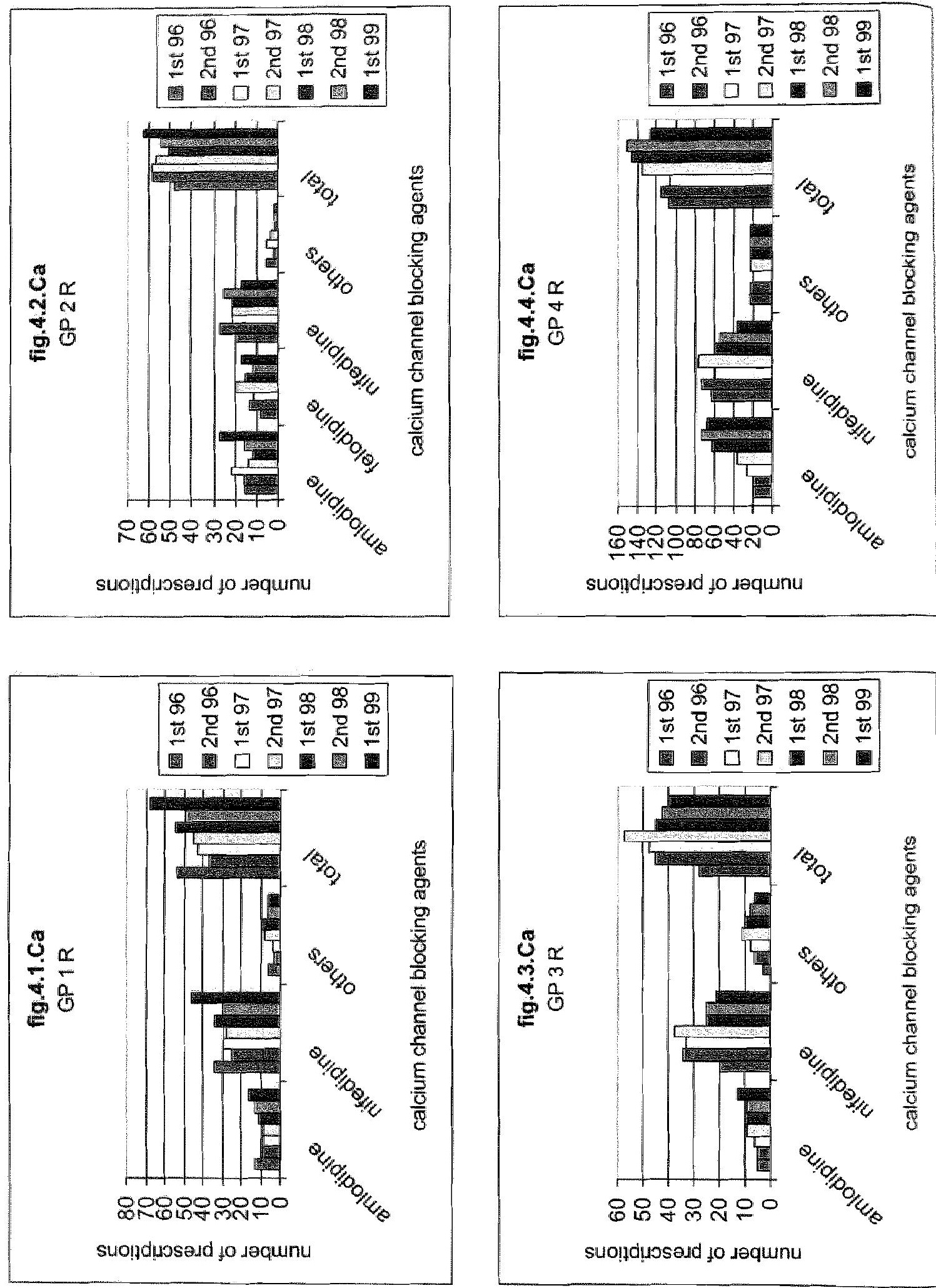

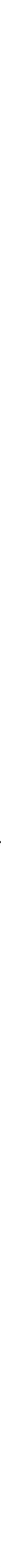


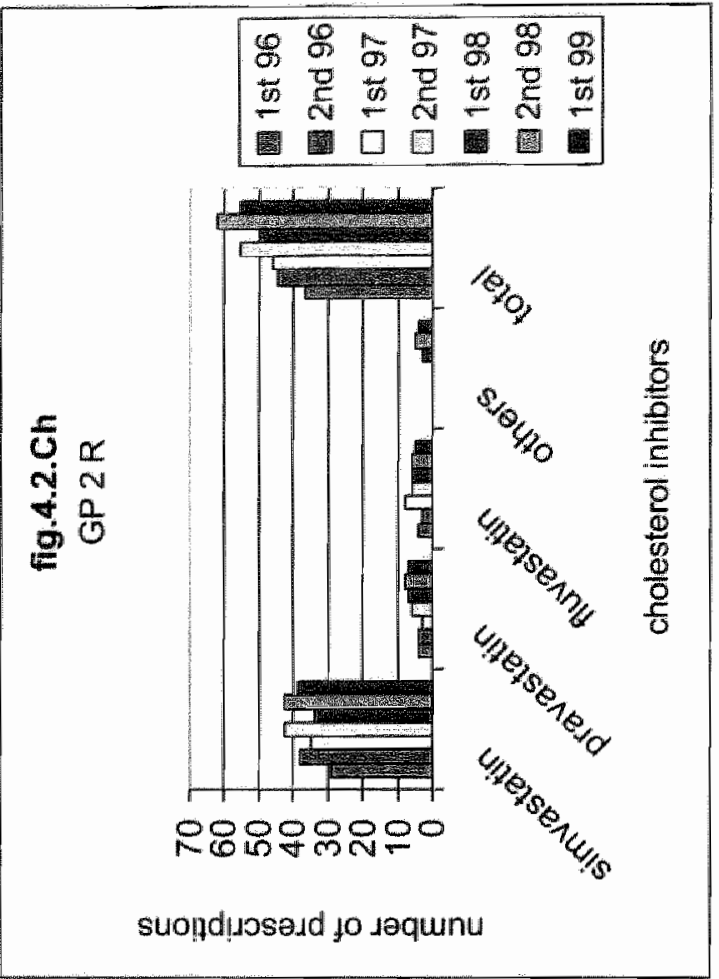

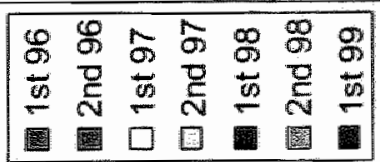
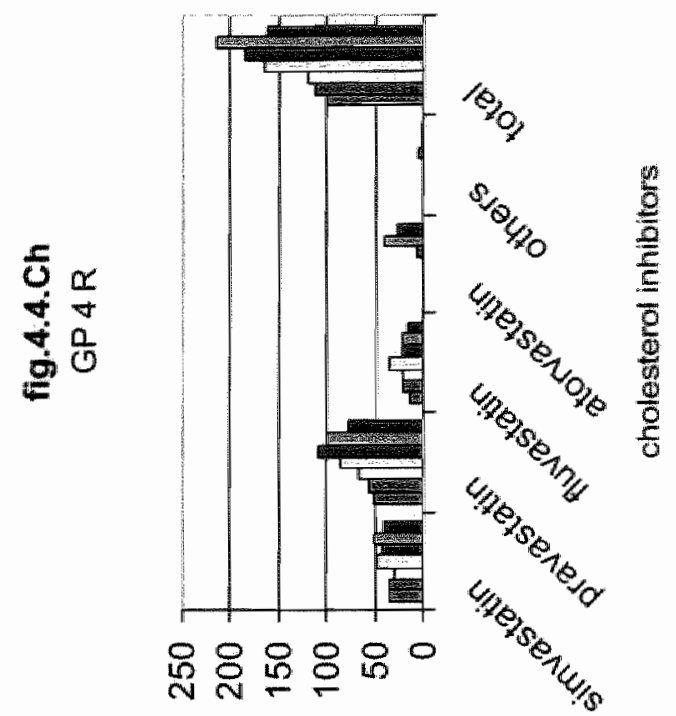

suondlusasd to saquinu
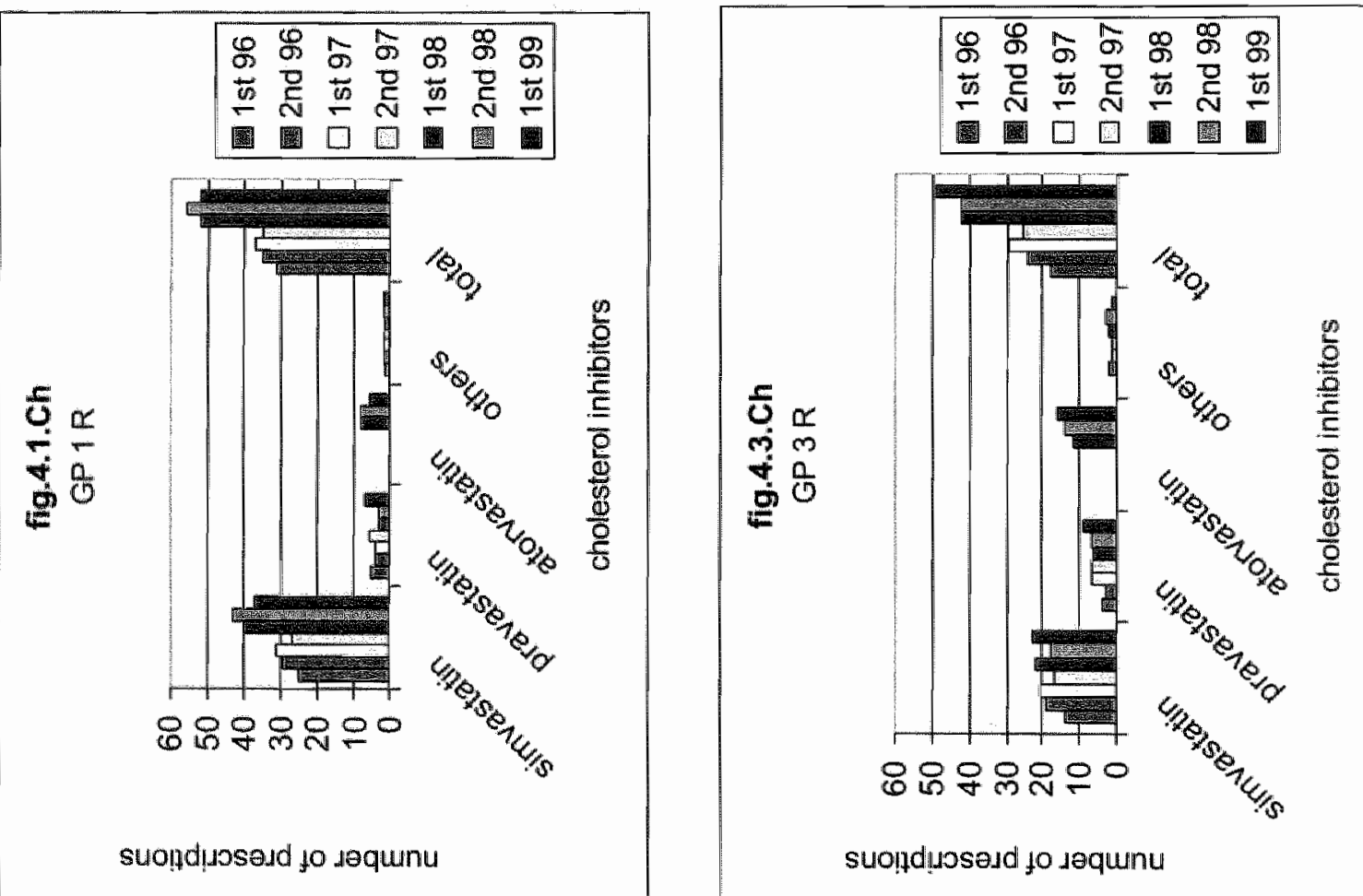

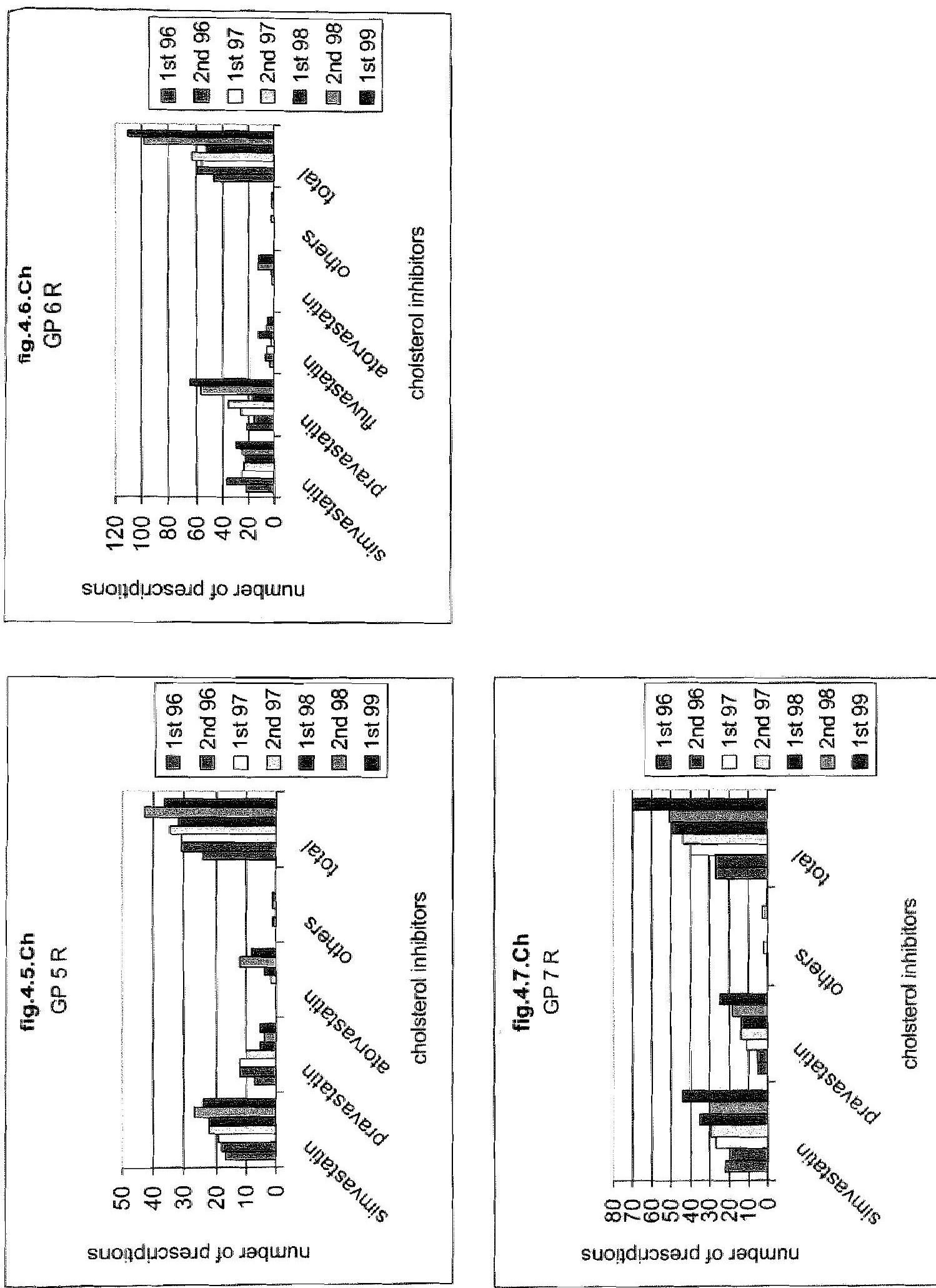

CHAPTER V

\section{LONG TERM INFLUENCE OF FORMULARY-BOUND DRUG PRESCRIPTION}

A COMPARATIVE INVESTIGATION ON THE INFLUENCE OF A REGIONAL LIMITED FORMULARY ON DRUG PRESCRIPTION

IN GENERAL PRACTICE 
Introduction. The prescription of drugs is an integral and important part of medical practice. Consequently, professional organisations introduced guidelines for treatment including formularies for a majority of common diseases $(117,118)$. Such a list of "drugs of choice' should lead to the use of a limited number of chemical entities with optimal pharmaco-therapeutic effects. Already many years ago a number of studies on rational prescription have been performed $(119,120)$. Many of these studies aimed not only at improving pharmacotherapy but also at reducing the ever increasing costs of treatment due to the continuous development of newer often expensive drugs $(121,152)$. The Dutch College of General Practitioners (NHG) published national guidelines for treatment which included recommended drugs for prescription (NHGguidelines). However, the introduction of national formularies was only hesitatingly and incompletely accepted (122). Many physicians experienced a certain degree of aversion to guidelines imposed by national authorities which they interpreted as undemanded interference with their professional independence and responsibility. They expressed their preference for regional or local formularies based on consensus in medical audit meetings. A good compliance might only be expected with a formulary composed in cooperation with the local practitioners and wherein they could recognise themselves $(64,123)$. This was effectuated in Asten. The Netherlands, by a regional group of seven GPs and the local pharmacists considering that a limited formulary might lead to a more conscious prescription behaviour and thus contribute to increasing experience and expertise of the prescribers. By mutual agreement they composed a list of recommended drugs and aimed to keep their prescriptions mainly within the limited scope of this regional computerised 'Asten formulary' (155).

In order to obtain information on the effects of formulary-bound prescription of drugs in general practice, we compared the prescription behaviour of the GPs in Asten (designated Audit-group) with the 'unbound' prescription behaviour in a Reference-group of GPs who used no specific local formulary and prescribed from the same ATC-categories.

The following parameters were compared:

- the variety in total numbers of prescribed different chemical entities/drugs;

- the variety in numbers of different 'drugs of personall preference';

- the compliance with NHG-guidelines in both A- and R-groups of GPs and with the A-formulary in the A-group;

- the longitudinal changes in prescription behaviour;

- prescription patterns in the regional patient populations;

- cost of pharmacotherapy in both regions. 


\section{Methods}

The general practitioners. In order to avoid deliberate influence of the GPS on the course of the investigation, they were not informed earlier than after collection of all prescriptions. Their permission was then asked and obtained to include their prescription data in our study.

General data on physicians and practices are summarised in table 5.1.

The Audit-group. In a semi-rural area a number of seven GPs provide medical care for a population of 13,899 patients. In common monthly pharmaco-therapeutic audit meetings of GPs and pharmacists a limited regional formulary has been composed and is regularly updated. This A-formulary was based on the professional experience and expertise of all participants. The NHG-guidelines were included in the discussion and by general agreement partly incorporated in the A-formulary which was installed and ready for use in every GP's computerised practice administration. The GPs voluntarily aimed to keep their prescriptions within its scope but necessary deviations were allowed. An important aspect was the commitment of all participants which was stimulated by the monthly feedback consultations.

Another item in the A-group was the relation with the pharmaceutical industry. In order to effectuate independent prescription it was agreed that none of the GPs received visits from medical representatives but that all contacts were maintained by the pharmacists. The obtained information, filtered by the professional knowledge of the pharmacists, was commented and distributed during the monthly meetings. In this way trial and error policy of the GPs in the prescription of new drugs could be prevented and the prescription spectrum kept limited (155).

The Reference group. In the reference group seven general practitioners participated who all had their practice in the same province in a middle size Dutch town. Together they served a population of 19,087 patients. Each physiclan was free to prescribe the drug of his choice from the relevant ATC-category. No binding to any formulary was agreed although like every Dutch GP they were familiar with the NHG-guidelines. On a more or less regular basis they participated in pharmaco-therapeutic audit meetings.

Data collection. The prescriptions from all participating GPs in the same region (A-region or $\mathrm{R}$-region) were registered and dispensed through one central pharmacy in each region. Prescription data were retrospectively collected from the computerised administration system of the central pharmacy.

Time span. All prescriptions from seven consecutive half year periods have been collected. Collection of prescriptions per half year periods was chosen in order to prevent registration of short duration bias of drug selection. Moreover, 
this time span enabled us to collect and study larger numbers of prescriptions per period. A clear picture of each physician's prescription behaviour was obtained per half year and over the whole period of 42 months.

Categories of drugs. In order to provide ample possibilities for selection of interchangeable drugs in each category, six ATC-categories of often prescribed drugs were included: NSAIDs (ATC code M01A), ACE inhibitors (C09A), antidepressants (N06A), beta-blocking agents (C07A), calcium-channel blocking agents (COBC) and cholesterol inhibitors (C10AA). The GPs in the R-group could freely choose any drug from the total number of 77 different chemical entities. For the A-group the number of interchangeable drugs for selection was principally determined by the A-formulary which reduced the number of recommended drugs to 15 chemical entities. Special attention was also payed to the prescription in both groups of 14 chemical entities which were recommended in the NHG-guidelines. For reasons of comparison, the complete ATC-lists are given with the selection of 15 drugs for the A-formulary and indication of 14 NHG-recommended drugs (table 5.2). Those drugs for which in any period of six months the number of prescriptions by any of the physicians exceeded $10 \%$ of total prescriptions in its group, were arbitrarily designated as "drugs of personal preference'. Prescriptions where this $10 \%$ limit was not reached were classified in a group 'other drugs'.

The prescriptions. For each patient under pharmaceutical treatment the physician decided on the most appropriate drug to be prescribed. In order to investigate the selection process all prescriptions per active ingredient from each individual prescriber were collected, classified according to ATC-categories and counted.

Special attention has been payed to the largest drug category (NSAIDs). Numbers of prescriptions in this category allowed to compare prescription behaviour in one category between GPs within each group.

Compliance with NHG-guidelines and with A-formulary. The compliance with the national guidelines (NHG-standards) and with the A-formulary was determined by counting all prescriptions per ATC-category and calculating the percentage of prescriptions where the A-formulary and/or the NHG-guidelines had been followed. E.g., if in one half year period 203 prescriptions for NSAIDs are prescribed by one GP, of which 77 for diclofenac, 75 for ibuprofen and 12 for nabumeton, the prescriptions in terms of percentage for the saild drugs are viz. $38 \%, 37 \%$ and $6 \%$. These three drugs together being the recommended medication in the NSAID category so produced a summarised compliance with the A-formulary of $81 \%$ in this period.

Compliance was calculated per GP in each group for each ATC-category in 
seven consecutive half year periods each. The longitudinal course of compliance could thus be studied. After calculation of all values a mean overall value for the A-group was determined for compliance with the A-formulary and with the NHG-guidelines. For the R-group the compliance with the NHG-guidelines was determined although no agreements on prescription following these guidelines had been made.

Longitudinal changes in prescription preference. In order to evaluate the longitudinal changes in preference for the prescription of certain drugs, the number of prescriptions for each drug in its ATC-category in every half year period has been registered. The varying numbers of prescriptions for each drug from one period to another demonstrated the changing preferences. A numerical evaluation of changing preferences was made by calculating the mean value and the coefficient of variation (c.v.) for the series of seven numbers of prescriptions i.e. preference for each drug over the entire period of seven consecutive half years. This calculation was made per drug and per physician. Moreover, the mean c.v. per ATC-category was determined. A small c.v. value points to a consistent preference for prescription of the concerned drug while larger values are connected with stronger varying preferences over the consecutive half year periods.

Regional 'prescription density'. Numbers of prescriptions have been related to numbers of registered patients in both the A-region and the R-region by calculating the 'prescription density' (numbers of prescriptions per 100 patients per 42 months) for each ATC-category and overall. Adjustments for different age distributions were made by indirect standardisation taking the total population of the Netherlands as a standard.

Data processing. Data in tables and graphical presentations are presented on prescription pattern per physician, per drug and category of drugs, per six months and over the whole 42 months period. Comparisons in numbers and percentages are given concerning both the situation in any six months period and on longitudinal changes. Moreover, the compliance of each physician with the A-formulary and/or with the NHG-recommended guidelines for treatment was registered by calculating the percentage of prescriptions for recommended drugs (A-formulary or NHG-guideline) on the total number of prescriptions.

Observed differences in specified aspects of prescription policy between the Agroup and the R-group were statistically evaluated with the chi-square test using a two sided significance level of $5 \%$. This concerned numbers and ranges of selected drugs, compliance with NHG-guidelines and prescription density. For the A-group the compliance with the A-formulary and with NHGguidelines was also compared. The variability of prescription preferences over 
the seven consecutive half year periods in both groups was andysed using coefficients of variation. Adjustment for age was carried out with indirect standardisation using the total Dutch population as the standard. Both patient groups were converted to virtual populations based on national age distributions.

Costs of pharmacotherapy. Data on expenditures for pharmacotherapy in both regions were kindly supplied by the health insurance companies. These will be dealt with in a separate chapter (ch. VII).

\section{Results}

In table 5.1 some characteristics on GP-practices in the A-group and in the Rgroup are presented. Although the number of GPs in both groups are equal the number of patients in the A-group is smaller than in the R-group. Consequently the number of patients in each separate practice in group $A$ was smaller than in group R. Moreover, in group $R$ the elderly patients ( $>65$ years of age) constitute a larger part (20.9\%) of the total patient population than in group A (15.4\%) whilst the opposite is true for the youngest age group. This will be taken into account when the overall drug consumption and related costs between both groups are compared. The ratio between male and female patients was equal in both groups.

Prescription behaviour in the A-group. A total number of 22,721 prescriptions for drugs from the six selected ATC-categories prescribed in 42 months, were retrospectively collected and studied. All GPs prescribed a variety of drugs from all categories, in total from $31-42$ out of a total number of 77 available drugs. Many drugs were selected outside the recommended A-formulary. From $17-24$ chemical entities were selected as "drugs of personal preference" (table 5.3). Detailed information on prescriptions per ATC-category is presented. It appeared that drugs of personal preference with few exceptions were prescribed in $90 \%$ of all prescriptions (tables $5.4 . a-f$ ).

The largest collection among the six categories in this study were the NSAIDs, for which in 42 months a total number of 10,034 prescriptions were registered (table 5.4.a). All GPs together prescribed 7-11 different chemical entities overall in this category but only $2-5$ drugs were selected as personal preference. The latter taken together covered $89-98 \%$ of all prescriptions in this category. Similar patterns were also observed in the other ATC-categories. Small numbers of drugs of personal preference were selected for ACE-inhibitors, Ca-channel blocking agents and cholesterol inhibitors (tables $5.4 . b, e, f)$. Larger selections were found for beta-blocking agents (table 5.4.d) and especially for anti-depressants (table 5.4.c). In the latter category many prescriptions were even registered outside the range of drugs of personal preference. Drugs listed in the A- 
formulary and/or in the NHG-guidelines are specially indicated.

The prescription of recommended NSAIDs by individual GPs is an example of prescription policy. Specified quantitative data were collected from each physician and for the group weighted means were determined (table 5.5).

In table 5.6 the compliance of GPs in the A-group with the A-formulary and with the NHG-guidelines is given and compared with the R-group for prescription of drugs from all six ATC-categories.

A graphical survey of longitudinal changes in prescription of specified drugs is presented in figs. 5.1-7, for each ATC-category and in table 5.7 a numerical survey and comparison between A-group and R-group is given. The degree of change was expressed by calculating the mean number of prescriptions for each drug over the seven consecutive half year periods with its coefficient of variation.

Prescription behaviour in the R-group. A full description and discussion of the prescription behaviour of the GPs in the reference group is presented in chapter IV.

Comparative investigation. The data concerning prescription behaviour in the A-group have been compared to the corresponding data obtained in the $\mathrm{R}$ group (cf. chapter IV, tables $4.2-4.6$ and figs $4.1-4.7$ ). The results of the comparative investigation are presented in tables $5.9-5.14$.

Differences in prescribing behaviour. In both groups the selection of drugs per ATC-category and per individual physician and per group has been recorded. The total number of prescriptions in the A-group in three and a half year was 22,721 (population 13,899) and in the R-group 41,131 (population 19,087). All GPs prescribed drugs from all six ATC-categories. The largest collection of prescriptions in both groups concerned the NSAIDs, in the Aregion $44 \%$ of all prescriptions and in the R-region $41 \%$.

The selection of drugs varied between individual physicians in both groups. A significant difference was found between the overall number of selected drugs, in the R-group ranging from 48-67 and in the A-group from 31-42. The ranges of 'drugs of personal preference' showed a similar difference (table 5.9). In the A-group the combined prescriptions for these drugs covered $94-98 \%$ of all prescriptions except for anti-depressants. A somewhat lower percentage of 88 $92 \%$ was registered in the R-group (table 5.8).

Compliance with NHG-guidelines and with A-formulary (table 5.6). Although the GPs in the R-group were not bound to any formulary, they often followed the NHG-guidelines (mean compliance 58\%). Good compliance was observed for cholesterol inhibitors and for NSAIDs but a low compliance (28\%) was observed for anti-depressants (table 5.6). In the A-group a better overall mean 
compliance with NHG-guidelines (70\%) was observed which was exceeded by compliance with the A-formulary $(82 \%)$. Surprisingly a lower mean compliance for NSAIDs was registered here with the A-formulary ( $87 \%$ ) than with the NHGguidelines $(93 \%)$. This appeared to be due to the apparent low preference for nabumetone (listed in the A-formulary) and the higher preference for NHGlisted naproxen. For the other ATC-categories the compliance with the A-formulary generally either exceeded or equalled the adherence to the NHG-guidelines (table 5.6). Studying the course of compliance with the A-formulary in the A-group over seven consecutive periods we observed a steady or increasing pattern for all ATC-categories. With the NHG-guidelines which only partially overlapped the A-formulary lower values were found. In the R-group for four ATC-categories poor compliance with the NHG-guidelines was observed and values were much lower than in the A-group for compliance with the A-formulary (table 5.9).

Longitudinal changes in prescription behaviour. A convenient survey of longitudinal changes was obtained by graphical presentation of preferences of each individual GP for prescription of specified drugs in consecutive half year periods (figs. 5.1 - 5.7, for each ATC-category). The GPs are indicated by numbers 1-7; the ATC-categories are indicated by characters viz. N, AC, AD, B, $\mathrm{Ca}$ and $\mathrm{Ch}$. Differences in longitudinal changes were registered and graphically illustrated by comparing figs. 5.1-7 for the A-group with figs. 4.1-7 (chapter IV) for the R-group. Numerical data on longitudinal changes in prescriptions (coefficients of variation for seven consecutive half year periods) for drugs of personal preference in all categories were calculated for both groups (tables 4.7 and 4.8). For comparison between groups a list of mean coefficients of variation per drug of personal preference is presented (table 5.7). Although the A-formulary contains only 15 drugs in the six ATC-categories together, still a total number of 32 different chemical entities have been prescribed in the A-group out of 77 drugs listed in the complete ATC-list. However, for about $90 \%$ and more of all prescriptions drugs of personal preference were selected mostly from the regional formulary. Consistent prescription behaviour (mean c.v. $<50 \%$ ) was observed in all ATC-categories, overall for 16 drugs (of which 7 listed in the Aformulary) out of a total number of 32 . Elevated c.v. values were found where significant changes in prescription preference were observed e.g. prescription of amlodipine by only one GP.

In the R-group consistent prescription was also observed although with more variety between the GPs in the group. A mean c.v. $<50 \%$ was registered for 21 from 41 different drugs of personal preference (table 5.7).

Prescriptions for NSAIDs. By far the largest proportion of prescriptions in both 
groups were prescribed for NSAIDs and the prescription policy for this ATCcategory is therefore presented (table 5.10) as an example for the study of several aspects of prescription behaviour. The majority of prescriptions in both groups were for drugs of personal preference, slightly better in the A-group where four GPs selected these drugs even in 95-98\%. In the R-group most of these drugs were taken from the NHG-guidelines whilst the GPs in the A-group followed the A-formulary. Remarkably, although nabumeton was indicated as recommended drug in the A-formulary, it was only selected as drug of personal preference by one of the physicians. Three GPs restricted their personal preference $(89-93 \%)$ to either diclofenac or ibuprofen (table 5.4 .a). These two drugs are also listed in the NHG-guidelines showing overlapping between the regional formulary and national guidelines. Personal preference in cornpliance with the NHG-guidelines was also registered in the R-group (table 3.3.a). From the preference for diclofenac and ibuprofen it can be concluded that evidently the expertise and experience on which the composition of the A-formulary was based goes in line with principles by which national guidelines were composed. For each physician and in each ATC-category the numbers of prescriptions in consecutive half year periods were registered and graphically depicted. Differences in prescription policy between GPs were observed. An example of longitudinal changes in prescription behaviour for NSAIDs is presented in figs. 5.1-7.N and 4.1-7.N (chapter IV). Sometimes there is a growing preference for a specified drug through the entire three and a half years period. E.g. the prescription of ibuprofen by one of the GPs gradually increased from $2 \%$ in the first half year to $54 \%$ in the last period. In the prescriptions of this physician the preference for diclofenac at the same time decreased from $78 \%$ to finally $34 \%$. Prescriptions for diclofenac seemed to be substituted by those for ibuprofen (fig. 5.1.N). This is an example of a steady and deliberate changing preference. Steady prescription levels were also observed (fig. $5.2 . \mathrm{N}$ ) as well as changing rise and fall of preference (fig. 5.6.N).

Similar prescription patterns have been observed in all ATC-categories. A deliberate selection of recommended drugs was sometimes hesitantly and incompletely made. Finally the number of prescriptions for a certain drug could increase because of apparently growing medical indication as was observed in the practice of one of the GPs who every half year prescribed more and more simvastatine (fig. 5.7. Ch) and another GP whose prescriptions for nifedipine (fig. 5.1.Ca) steadily increased. In individual cases deliberate longitudinally changing selection of drugs was observed (e.g. figs. 5.1.N, 5.1. Ca, 5.3.AC, 5.3.AD and 5.3.B) which also led to elevated c.v. values but inconsistent prescribing behaviour was also observed (e.g. figs. 5.5.AC and 5.5.AD). 
Regional prescription patterns. Differences were found between prescription densities (numbers of prescriptions/100 patients) in the A-region (163.4) compared with the R-region (215.5), i.e. $31.8 \%$ more prescriptions $/ 100$ patients/42 months in the R-group (table 5.11). This could partly be explained by the fact that in the R-group the proportional population of elderly patients exceeded this population in the A-group (table 5.1). After adjustment for different age ranges (table 5.12) these figures were converted to 156.2 prescr. $/ 100$ pat./42 months in the A-group and 180.6 prescr. $/ 100$ pat./42 months in the R-group. The number of prescriptions in the R-group still exceeds the number in the A-group by $15.7 \%$ (table 5.13 ). About half of the actual excess appeared to be due to age differences.

Differences between proportional prescription densities (percentages of prescriptions per ATC-category vs. total number of prescriptions) were less pronounced especially for the larger ATC-categories: NSAIDs $44 \%$ vs. $40 \%$ and beta-blocking agents $19 \%$ vs. $18 \%$ (table 5.13 ). A striking difference was observed for the percentage prescriptions of cholesterol synthesis inhibitors which was remarkably lower in the A-region (4\%) than in the R-region (7\%). This might be connected with marketing activities by medical representatives from pharmaceutical industries: as a matter of fact, promotional activities for NSAIDs appeared to be limited whilst promotional activities for ACE-inhibitors and cholesterol synthesis inhibitors were much more intensive. It must be reminded that in the A-region the reception of medical representatives was restricted to the local pharmacists. Consequently the direct influence of promotional activities on the GPs' prescription behaviour in the A-region was much less than in the R-region.

\section{Discussion}

A limited formulary is supposed to lead to a more conscious prescription behaviour which contributes to increasing experience and expertise of the physicians (118). Comparable procedures have been published by other investigators $(113,210)$. The quality of medical practice will be improved and this is certainly to the benefit of both the doctors and the patients. Moreover, if such a limited formulary has been composed by the GPs themselves who use it in their own practice, a good compliance may be supposed (64). Experience and expertise of the physicians on which the selection of drugs is based will increase by retrospective evaluation and updating of the formulary. Finally a reduction of costs per patient for pharmacotherapy might be expected as was reported elsewhere (152).

Prescription behaviour. The selection of an ATC-category followed by the 
choice of an active ingredient c.q. chemical entity in this category determines which drug actually will be prescribed. So far drug selection did not depend on dosage or way of administration. Assuming that all prescriptions are clinically indicated the Dutch College of General Practitioners (NHG) has published guidelimes for treatment, including pharmacotherapy, for a number of diseases suggesting prescription of specified drugs. All GPs in both groups disposed of these guidelines as well as of the complete ATC-list. However, in the A-formulary on the doctor's desk in the A-group only a limited number of drugs per ATC-category was listed as preferable for prescription so that intuitive selection of drugs outside the formulary was discouraged. In the R-group no such restrictions existed.

The GPs in the A-group voluntarily aimed to select drugs from the A-formulary, which had been composed by mutual agreement in pharmaco-therapeutic audit meetings in which all GPs and the local pharmacists participated. As in comparable situations the GPs accepted the professional influence of the latter $(30$, 31) although this could lead to differences with e.g. national guidelines. That the formulary was based on personal expertise and experience of local pharmacists and physicians (155) was in line with other prescription trials $(118,119$, 121). It is not surprising that an overlap between the A-formulary and the NHGguidelines was registered for 8 drugs (table 5.2) because both recommendations aim at a common target. Overlapping recommendations were observed in all ATC-categories except for anti-depressive drugs. It must be remarked that complete absence of overlapping recommendations might raise questions as to the validity of either the national or the regional formulary. Nevertheless, this was observed for the category of anti-depressants where three drugs were recommended in the NHG-guidelines and three other drugs listed in the Aformulary. Similar observations were made by other authors (54) but smaller differences between formularies for GPs have also been reported $(64,123)$ as could be explained by different experiences and opinions between GPs (131) and by the influence of local pharmacists $(30,31)$. However, good agreements between NHG-guidelines and the A-formulary suggested that the latter goes in line with principles on which national guidelines have been based. This was e.g. illustrated for the prescription of e.g. diclofenac and ibuprofen and many other drugs which were selected by GPs in both R-group and A-group.

Selection of drugs outside formulary or guidelines might be due to trial and error behaviour or to other influences such as a patient's preference, continuation of a specialist's prescription, etc. However, drugs selected as personal preference were for the greater part restricted to the recommended drugs as listed in the formulary (tables 5.4.a-f). In the category of anti-depressants a 
large prescription spectrum might indicate uncertainty of diagnosis and trial and error behaviour of therapy (table 5.4.c).

Compliance. Prescribers both in the R-group as well as in the A-group selected drugs from all ATC-categories. The GPs in the R-group prescribed 48-67 different chemical entities which is $62-86 \%$ of all available drugs. A substantially smaller spectrum might be expected in the A-group and indeed selection of 31 42 drugs ( $40-54 \%$ of available drugs) was observed. A similar but smaller difference was registered for the selection of drugs of personal preference. This limitation of the variety of prescribed drugs indicates a more rational prescription policy by GPs in the A-group. Comparable results have been reported by Bergman et al. (210) who used the DU- $90 \%$ as a parameter for prescription quality.

Although the A-formulary meant to be of major influence on prescription in the A-group, other factors such as patients' demands and introduction of new drugs could not be neglected $(13,16)$. A variety of drugs outside the formulary in all six ATC-categories was prescribed in individual cases (table 5.9). However, "drugs of personal preference" were for the greater part selected from the Aformulary except for antidepressants. In the A-group (up to 12 different drugs) as well as in the R-group (up to 20 different drugs) the large prescription spectrum for anti-depressants might indicate uncertainty of diagnosis and trial and error behaviour of therapy. It has been suggested that prescription of antidepressants in general practice often raises problems both in making the correct diagnosis and also concerning selection of optimal therapy $(54,41)$. These problems evidently were recognised in the discussions in the pharmaco-therapeutic audit meetings in the A-group. As a result common agreement on medication was reached and the compliance with the A-formulary longitudinally developed from $48 \%$ to $71 \%$ (mean $65 \%$ ) of prescriptions for anti-depressants. This was in contrast with the prescriptions for these drugs in the R-group where no mutual agreement between GPs existed and the compliance with the NHGguidelines decreased longitudinally from $35 \%$ to $26 \%$; the mean value over the whole period was 30\% (table 5.9).

In the categories of ACE-inhibitors, calcium-channel blocking agents and cholesterol inhibitors the compliance with the A-formulary was better than $90 \%$ (mean values) of all prescriptions. No doubt the existence of the formulary contributed to consistent prescription behaviour which is supposed to be in line with good medical practice (120).

Prescription discipline evidently led to rational and consistent prescribing behaviour and a steady or increasing compliance pattern confirms such a policy. From these data it can be concluded that in the A-group a better prescription 
policy was found than in the R-group.

Longitudinal variety in prescription. One of the explicit aims in compiling a limited formulary for use in general practice has been described as to avoid the inclusion of drugs which have been in use for less than five years unless there is overwhelming evidence of a drug's advantage over older preparations (118). Long term unchanged medication in general practice is often based on favourable experiences with the concerned drugs and evidence of adequate therapy and has been supported even in academic hospitals where in general new drugs are easily introduced (33). In our study the A-formulary evidently influenced prescription behaviour to a large extent. A low coefficient of variation indicates a steady preference for the concerned drug whereas larger values point to larger changes in selection preference (table 5.5). Such changes may be the result of deliberate prescription policy following PTAM agreements causing gradually increasing or decreasing of prescription of a certain drug, e.g. the prescription of ibuprofen by one GP who gradually substituted this drug for other NSAIDs. Varying selection leading to elevated c.v. values could also be due to uncertainty and trial and error policy. In the A-group prescription stability was better than in the R-group which could be evaluated as a positive effect of formulary-bound prescription behaviour. This implicates that the study of longitudinal variety in prescription is useful for evaluation of the efficacy of an introduced formulary.

Some controversy is observed in the literature where it has been reported that patients' preference has a very strong influence on prescription behaviour and maintenance $(14,13,16,88)$. On the other hand the use of a limited formulary (114) and the fact that many adverse drug reactions remain unreported (105) can be helpful in discussions to convince patients whenever changes in medication are inevitable (77).

In individual cases deliberate longitudinally changing selection of drugs was observed, which also led to elevated C.V. values but inconsistent prescriptions were also observed. Deliberate changing drug selection may be supposed to result from pharmaco-therapeutic audit meetings as practised in the A-group, positively illustrating growing tendencies to prescribe in line with the formulary. This could be illustrated by the increasing total numbers of prescriptions for ACE-inhibitors and for cholesterol inhibitors following the new recommendations of the revised NHG-guidelines (figs. 5.1-7.AC and 5.1/2/5/7.Ch) and the increasing amounts of prescriptions for ibuprofen and paroxetine following formular agreements (figs. 5.1/3.N and 5.2/6.AD).

NSAIDs. The selection of NSAIDs as a representative ATC-category was based on the fact that these are often prescribed drugs allowing general con- 
clusions on prescription policy to be drawn (143, 144, 145). A detailed study was possible because sufficient prescriptions could be collected for evaluation and comparison between GPs within the A-group and within the R-group and between groups. The results obtained here support the validity of the general conclusions of the study i.e. more restricted prescription policy in the A-group and as might be expected less mutual variety between prescriptions in the Agroup than in the R-group. It must be remarked that the GPs from this group reported to prescribe paracetamol for a number of patients although this drug was not listed in the formulary and escaped our study.

Regional prescription patterns. Comparing overall prescription patterns between A-region and R-region no large differences were observed in the proportional distribution in terms of percentage of prescriptions over the six ATC-categories (table 5.11) especially for the larger categories NSAIDs and beta-blocking agents. This suggested the existence of similar morbidity patterns which was also concluded from interviews with the GPs from each group. Comparison of statistical data on health and morbidity in both regions could not be performed, however, due to different registration methods of local health authorities as was also reported by other investigators (35). Remarkably lower percentages of prescriptions were found in the A-group for cholesterol synthesis inhibitors and also for Ca-entry blocking agents. The GPs explained this by a reluctant attitude towards prescription of these drugs which they initially considered not to belong to the medication for prescription in general practice.

Despite similar morbidity patterns it appeared that not only the variety of prescribed drugs in the A-group was smaller than in the R-group but the total number of prescriptions per 100 patients was evidently smaller too. Partly this could be due to a larger proportion of elderly patients in the R-region. On a national scale data on the relation between age distribution and prescription of drugs are available (132) demonstrating that drug consumption and drug expenditures in the elderly population strongly exceed the national average (table 5.14). Using these data the influence of different age distributions between Agroup and R-group could be eliminated by conversion of both patient populations to the same virtual age distribution based on national figures. Still existing differences between both groups after age correction must be attributed to different prescription policies. In multiple linear regression analysis it was confirmed that the influence of practice group $(A=1 ; R=0)$ was highly significant and independent from practice size and age distribution (cf. table 7.10).

After adjustment for age differences (table 5.12) the number of prescriptions per 100 patients in the A-group (table 5.11) would be reduced to 156.2 and to 180.6 in the R-group in three and a half years. For the six ATC-categories 
involved this means 0.446 prescriptions/patient/year in the A-region and 0.516 $\mathrm{pr} . / \mathrm{pat} / \mathrm{year}$ in the R-region. This leaves a difference of $15.6 \%$ more prescriptions in the R-group due to differences in prescription policies between both groups. Evidently the GPs in the A-group had written out less prescriptions per patient than their colleagues in the R-group which indirectly must be attributed to PTAM agreements and perhaps also to the absence of direct marketing influence of medical representatives.

\section{Conclusions}

In the Audit group monthly pharmaco-therapeutic audit meetings and the use of a formulary influenced gradually changing prescription behaviour towards recommended drugs. The compliance with the A-formulary longitudinally developed favourably. It is beyond doubt that this contributes to increased practical experience and expertise of the general practitioners. The compliance even with NHG-guidelines in the A-group was better than in the R-group demonstrating lack of prescription discipline in the latter group.

Comparing formulary-bound prescription behaviour in the A-group vs. "unbound" prescription in the R-group we registered a significantly lower number of prescriptions overall and per 100 patients in the A-group, accompanied by an important reduction of costs (see chapter VIII). In almost every aspect a more reluctant attitude characterised the prescription policy in the A-group. This may be supposed to be due to continuing education and discussions on diagnoses and treatments during PTAMs leading to better awareness of the effects of pharmacotherapy. Moreover, considering the often big efforts of the pharmaceutical industry to promote their products by direct mail and personal contacts with GPs through medical representatives, the absence of the latter contacts in the A-group can be supposed to avoid 'trial' of new drugs by individual physicians and to strengthen compliance with the formulary.

Evidently the voluntarily acceptation and introduction of a regional formulary based on common experience and expertise in a group of general practitioners led to a more consistent prescription behaviour. An increasingly conscious selection of drugs and growing compliance with the formulary stimulated growing experience and expertise of the general practitioners to the benefit of medical practice.

References: cf. general reference list (chapter II). 


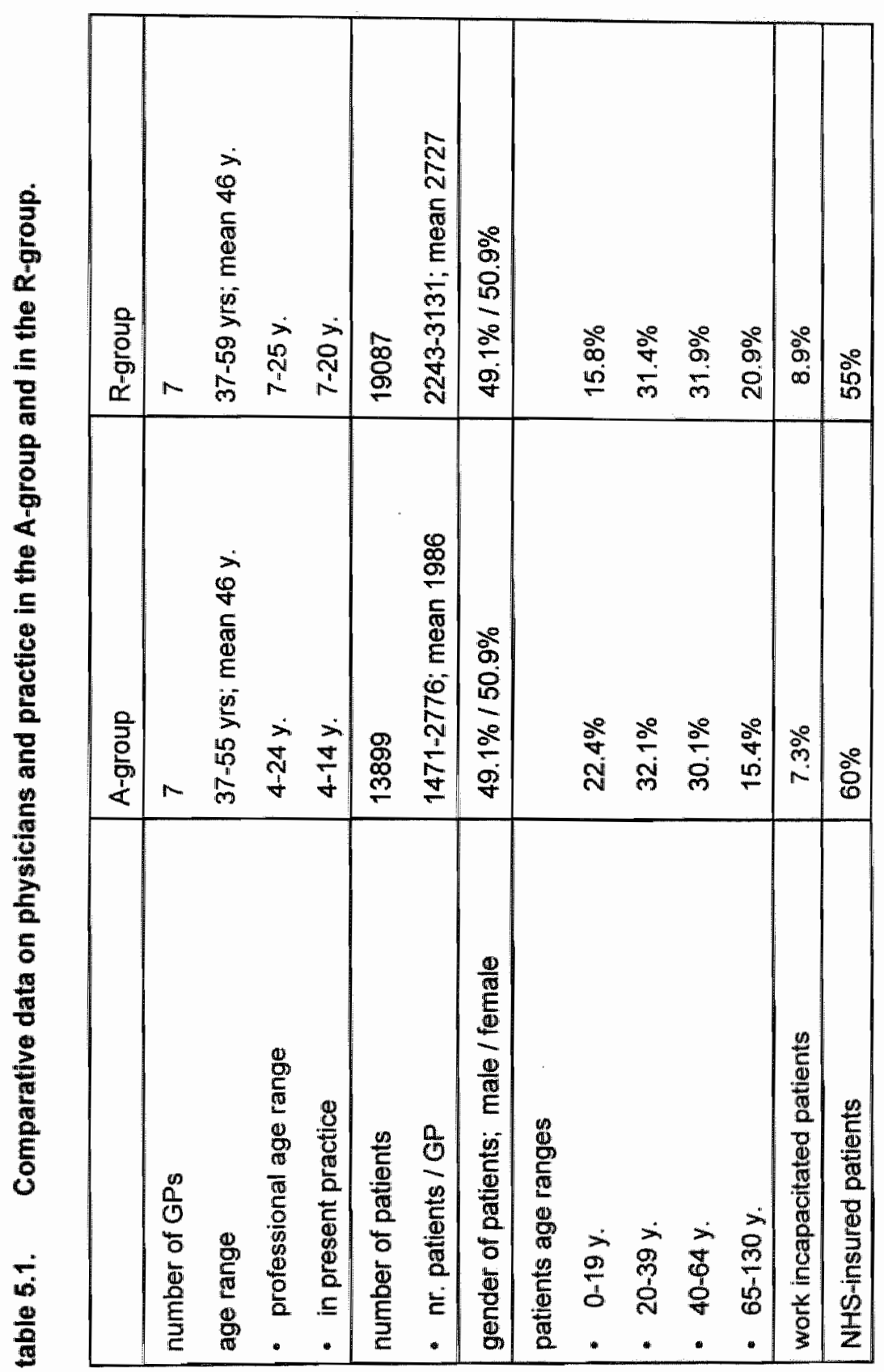


table 5.2. ATC-categories with indication of drugs listed in the A-formulary and in the NHG-guidelines.

\begin{tabular}{|c|c|c|c|c|c|}
\hline NSAIDS & $\begin{array}{l}\text { ACE- } \\
\text { inhibitors }\end{array}$ & $\begin{array}{l}\text { anti- } \\
\text { depressants }\end{array}$ & $\begin{array}{l}\text { beta-blocking } \\
\text { agents }\end{array}$ & $\begin{array}{l}\text { Ca-channel } \\
\text { block. }\end{array}$ & $\begin{array}{l}\text { chol. } \\
\text { inhibitors }\end{array}$ \\
\hline M01A & CO9A & NOEA & COTA & $\mathrm{COBC}$ & C10AA \\
\hline \multicolumn{6}{|l|}{ A-formulary } \\
\hline diclofenac & captopril & paroxetine & |atenolol & nifedipine & simvastatin \\
\hline ibuprofen & enalapril & clomipramine & pindolol & amlodipine & pravastatin \\
\hline nabumetone & & moclobemide & & & fluvastatin \\
\hline \multicolumn{6}{|l|}{ NHG-guidelines } \\
\hline diclofenac & captopril & amitriptyline & atenolol & nifedipine & Simvastatin \\
\hline ibuprofen & enalapril & imipramine & metoprolol & nitrendipine & pravastatin \\
\hline naproxen & & fluvoxamine & & & \\
\hline \multicolumn{6}{|l|}{ complete ATC-list } \\
\hline aceclofenac & benazepril & amitriptyline & acebutolol & amlodipine & atorvastatin \\
\hline azapropazone & captopril & citalopram & alprenolol & felodipine & cerivastatin \\
\hline diclof./misopr. & cilazapril & clomipramine & atenolo & irsadipine & fluvastatin \\
\hline diclofenac & enalapril & desipramine & betaxolol & lacidipine & pravastatin \\
\hline fenylbutazone & fosinopril & dosulepine & bisoprolol & lercanidipine & simvastatin \\
\hline flurbiprofen & lisinopril & doxepine & carvedilol & mibefradil & \\
\hline buprofen & perindopril & fluoxetine & celiprolol & nicardipine & \\
\hline indometacin & quinapril & fluvoxamine & |abetalol & nifedipine & \\
\hline ketoprofen & ramipril & imipramine & metoprolol & nimodipine & \\
\hline meloxicam & trandolapril & maprotiline & nebivolal & nisoldipine & \\
\hline nabumetone & & milanserine & oxprenolol & nitrendipine & \\
\hline naproxen & & mirtazapine & pindolol & & \\
\hline piroxicam & & moclobemide & propanolol & & \\
\hline tenoxicam & & nefazodone & sotalol & & \\
\hline tiaprof.acid & & nortriptyline & tertatolol & & \\
\hline tolfenamic acid & & paroxetine & & & \\
\hline & & sertraline & & & \\
\hline & & trazodone & & & \\
\hline & & trimipramine & & & \\
\hline & & venlafaxine & & & \\
\hline total numbers 16 & 1 & 20 & 15 & 1 & \\
\hline
\end{tabular}

' withdrawn from the market on account of interactions 


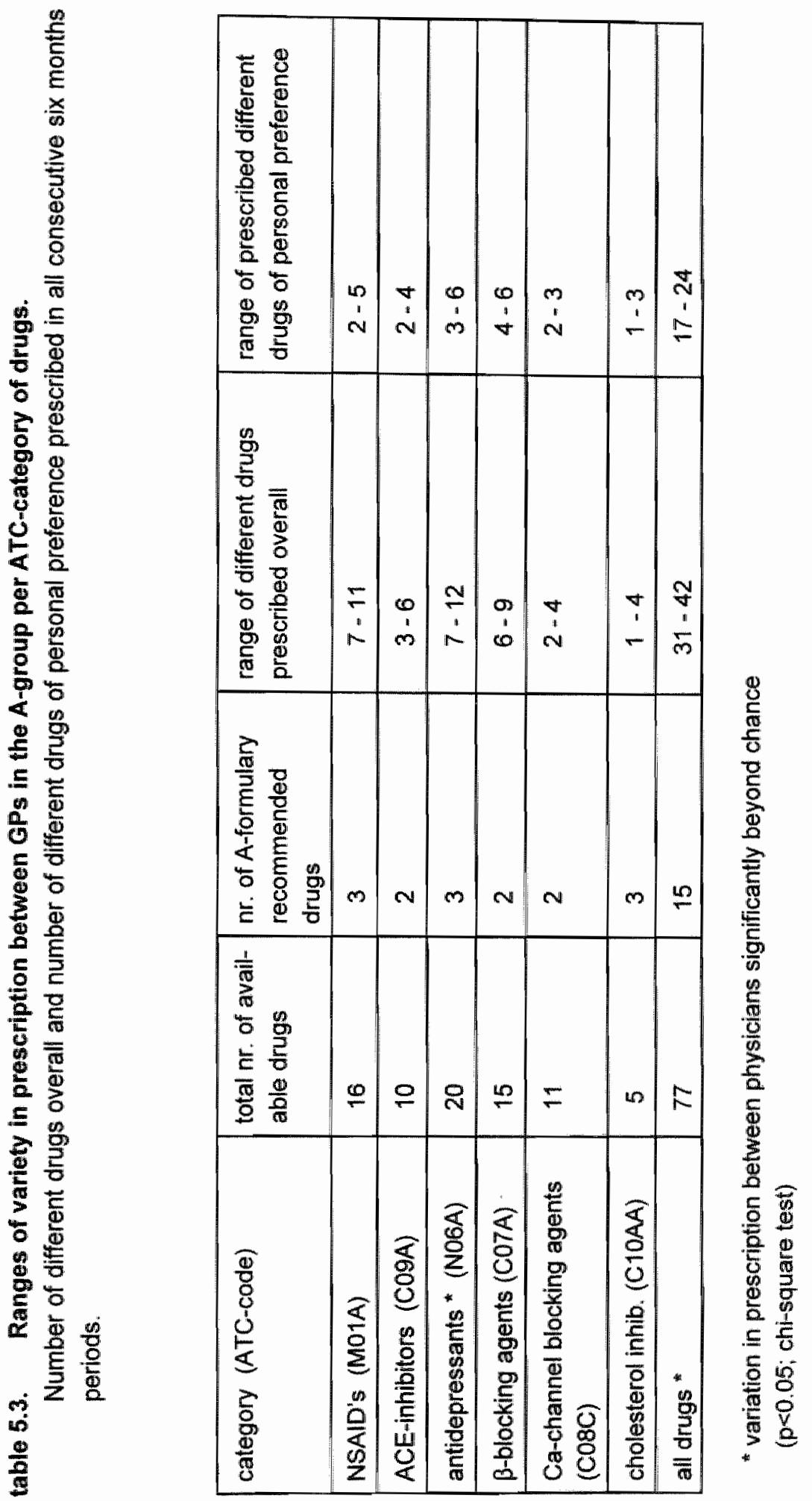


table 5.4.a. NSAIDs prescribed by individual physicians

in a period of $\mathbf{4 2}$ months.

Varying selection of drugs of personal preference (prescriptions $>10 \%$ ) with percentage prescriptions and selection of other drugs with percentage prescriptions; number of different drugs with total number of prescriptions.

\begin{tabular}{|c|l|l||l|l|l||c|}
\hline $\begin{array}{l}\text { A - } \\
\text { group }\end{array}$ & $\begin{array}{l}\text { personal } \\
\text { preference }\end{array}$ & $\begin{array}{l}\text { percent } \\
\text { prescr. }\end{array}$ & other drugs & $\begin{array}{l}\text { percent } \\
\text { prescr. }\end{array}$ & $\begin{array}{l}\text { nr. diff. } \\
\text { drugs }\end{array}$ & $\begin{array}{l}\text { total nr. } \\
\text { prescr. }\end{array}$ \\
\hline GP 1 & $1,2,3,5,15$ & $98 \%$ & $4,6,9,11,16$ & $2 \%$ & 10 & 1166 \\
\hline 2 & $1,2,3$ & $97 \%$ & $\begin{array}{l}4,5,6,8,9,11, \\
15\end{array}$ & $3 \%$ & 10 & 1894 \\
\hline 3 & 1,2 & $93 \%$ & $\begin{array}{l}3,5,6,8,9,13, \\
15\end{array}$ & $7 \%$ & 9 & 715 \\
\hline 4 & $1,2,3$ & $96 \%$ & $\begin{array}{l}5,6,8,9,10,13, \\
15,16\end{array}$ & $4 \%$ & 11 & 2240 \\
\hline 5 & 1,2 & $91 \%$ & $\begin{array}{l}3,5,6,9,11, \\
15\end{array}$ & $9 \%$ & 8 & 996 \\
\hline 6 & 1,2 & $89 \%$ & $\begin{array}{l}3,5,6,7,8,13, \\
15\end{array}$ & $11 \%$ & 9 & 1585 \\
\hline 7 & $1,2,3$ & $95 \%$ & $\begin{array}{l}5,9,11, \\
15\end{array}$ & $5 \%$ & 7 & 1438 \\
\hline
\end{tabular}

legend drug identification numbers:

- NHG-recommended drugs:

1-diclofenac; 2-ibuprofen; 3-naproxen.

- Asten formulary recommended drugs: 1-diclofenac; 2-ibuprofen; 15-nabumetone.

- other drugs: 4-aceclofenac; 5-diclofenac/misoprostole; 6-piroxicam; 7-tenoxicam; 8-meloxicam; 9-indometacin; 10-sulindac; 11-ketoprofen; 12-flurbiprofen; 13-tiaprofenic acid; 14-tolfenaminic acid; 16-azapropazone. 
table 5.4.b. ACE-inhibitors prescribed by individual physiclans in a period of $\mathbf{4 2}$ months.

Varying selection of drugs of personal preference and other drugs.

\begin{tabular}{|c|l|l|l|l|l|l|}
\hline A-group & pers.pref. & $\%$ prescr. & $\begin{array}{l}\text { other } \\
\text { drugs }\end{array}$ & $\%$ prescr. & $\begin{array}{l}\text { nr. diff. } \\
\text { drugs }\end{array}$ & $\begin{array}{l}\text { total nr. } \\
\text { prescr. }\end{array}$ \\
\hline GP 1 & $\mathbf{1 , 2}, 5$ & $100 \%$ & - & - & 3 & 222 \\
\hline 2 & $\underline{\mathbf{1}} \underline{\mathbf{2}}$ & $97 \%$ & $3,6,8$ & $3 \%$ & 5 & 605 \\
\hline 3 & $\underline{\mathbf{1}}, \mathbf{2}, 3,4$ & $100 \%$ & - & - & 4 & 191 \\
\hline 4 & $\underline{\mathbf{1}}, \mathbf{2}$ & $97 \%$ & $\mathbf{3}, 4,8$ & $3 \%$ & 5 & 655 \\
\hline 5 & $\underline{\mathbf{1}}, \mathbf{2}, 3,4$ & $98 \%$ & 6,8 & $2 \%$ & 6 & 215 \\
\hline 6 & $\underline{\mathbf{1}}, \mathbf{2}$ & $94 \%$ & $3,4,5,8$ & $6 \%$ & 6 & 359 \\
\hline 7 & $\mathbf{1}, \mathbf{2}, 3$ & $90 \%$ & $4,5,8$ & $10 \%$ & 5 & 343 \\
\hline
\end{tabular}

legend drug identification numbers:

- NHG-recommended drugs:

= Asten formulary recommended drugs:

- other drugs: 1-captopril; 2-enalapril

1-captopril; 2-enalapril

3-lisinopril; 4-perindopril; 5-ramipril;

6-fosinopril; 7-trandolapril; 8-quinapril 
table 5.4.c. Anti-depressants prescribed by individual physicians in a period of $\mathbf{4 2}$ months.

Varying selection of drugs of personal preference and other drugs.

\begin{tabular}{|c|l|c|l|l|l|l|}
\hline A-group & pers.pref. & $\%$ prescr. & other drugs & $\begin{array}{l}\% \\
\text { prescr. }\end{array}$ & $\begin{array}{l}\text { nr. diff. } \\
\text { drugs }\end{array}$ & $\begin{array}{l}\text { total nr. } \\
\text { prescr. }\end{array}$ \\
\hline GP 1 & $\begin{array}{l}1,3, \underline{4}, \underline{5} \\
11,19\end{array}$ & $91 \%$ & $\begin{array}{l}2,12,14, \\
17,20\end{array}$ & $9 \%$ & 11 & 496 \\
\hline 2 & $1, \underline{4}, \underline{5}, 19$ & $87 \%$ & $\begin{array}{l}3,11,12,13, \\
14,16,17,20\end{array}$ & $13 \%$ & 12 & 589 \\
\hline 3 & $3, \underline{4}, \underline{5}, \underline{6}$ & $95 \%$ & $1,9,17$ & $5 \%$ & 7 & 246 \\
\hline 4 & $1,3, \underline{4}, \underline{5}, 11$ & $82 \%$ & $\begin{array}{l}2,6,9,12,14, \\
15,16\end{array}$ & $18 \%$ & 12 & 685 \\
\hline 5 & $1,3, \underline{4}, \underline{5}$ & $98 \%$ & $2,9,11$ & $2 \%$ & 7 & 372 \\
\hline 6 & $3, \underline{4}, \underline{5}$ & $89 \%$ & $\begin{array}{l}1,2,6,9,11, \\
12,13,14,20\end{array}$ & $11 \%$ & 12 & 839 \\
\hline 7 & $\underline{4}, \underline{5}, 11$ & $87 \%$ & $\begin{array}{l}1,3,12,14 \\
16,18\end{array}$ & $13 \%$ & 9 & 569 \\
\hline
\end{tabular}

legend drug identification numbers:

- NHG-recommended drugs: 1-amitriptyline; 2-imipramine; 3-fluvoxamine.

- Asten formulary recomm. drugs: 4-paroxetine; $\underline{5}$-clomipramine; $\underline{6}$-moclobemide.

- other drugs: 7-citalopram; 8-desipramine; 9-dosulepine; 10 -doxepine;

11-fluoxetine; 12-maprotiline; 13-mianserine; 14- mirtazapine;

15-nefazodon; 16-nortriptyline; 17-sertraline; 18-trazodone;

19 -trimipramine; 20 -venlafaxine. 
table 5.4.d. Beta-blocking agents prescribed by individual physicians in a period of $\mathbf{4 2}$ months.

Varying selection of drugs of personal preference and other drugs.

\begin{tabular}{|c|l|l|l|l|l|l|}
\hline A-group & pers.pref. & $\%$ prescr. & other drugs & $\begin{array}{l}\% \\
\text { prescr. }\end{array}$ & $\begin{array}{l}\text { nr. diff. } \\
\text { drugs }\end{array}$ & $\begin{array}{l}\text { total nr. } \\
\text { prescr. }\end{array}$ \\
\hline GP 1 & $\begin{array}{l}1,2,3,7, \\
14,15\end{array}$ & $99 \%$ & 8 & $1 \%$ & 7 & 559 \\
\hline 2 & $\begin{array}{l}1,2,3 \\
14,15\end{array}$ & $99 \%$ & 10 & $1 \%$ & 7 & 540 \\
\hline 3 & $\begin{array}{l}1,2,3 \\
14,15\end{array}$ & $96 \%$ & 7,8 & $4 \%$ & 7 & 323 \\
\hline 4 & $1,3,14,15$ & $94 \%$ & $2,7,8,9$ & $6 \%$ & 8 & 876 \\
\hline 5 & $\begin{array}{l}1,3,7, \\
14,15\end{array}$ & $95 \%$ & 2 & $5 \%$ & 6 & 269 \\
\hline 6 & $1,3,14,15$ & $90 \%$ & $2,7,8$ & $10 \%$ & 7 & 769 \\
\hline 7 & $\begin{array}{l}1,2,3 \\
14,15\end{array}$ & $95 \%$ & $7,8,9,12$ & $5 \%$ & 9 & 1025 \\
\hline
\end{tabular}

legend drug identification numbers:

- NHG-recommended drugs: 1-atenalol; 2-metoprolol.

- Asten formulary recomm. drugs: 1-atenolol; $\underline{3}$-pindolol.

- other drugs: : $\quad$ 4-acebutolol; 5-alprenolol; 6-betaxolol; 7-bisoprolol; 8-carvedilol; 9-celiprolol; 10-labetalol; 11-nebivolol; 12-oxprenolol;

13-propranolol; 14-sotalol; 15-tertatolol. 
table 5.4.e. Calcium-channel blocking agents prescribed by individual physicians in a period of $\mathbf{4 2}$ months.

Varying selection of drugs of personal preference and other drugs.

\begin{tabular}{|c|l|l|l|l|l|l|}
\hline A-group & pers.pref. & $\%$ prescr. & other drugs & $\begin{array}{l}\% \\
\text { prescr. }\end{array}$ & $\begin{array}{l}\text { nr. diff. } \\
\text { drugs }\end{array}$ & $\begin{array}{l}\text { total nr. } \\
\text { prescr. }\end{array}$ \\
\hline GP 1 & $1,2$. & $99 \%$ & 9 & $1 \%$ & 3 & 221 \\
\hline 2 & $1,2$. & $100 \%$ & - & - & 2 & 214 \\
\hline 3 & $1,2$. & $92 \%$ & 3 & $8 \%$ & 3 & 75 \\
\hline 4 & 1,2, & $98 \%$ & 3 & $2 \%$ & 3 & 127 \\
\hline 5 & 1,2, & $99 \%$ & 8 & $1 \%$ & 3 & 109 \\
\hline 6 & $\underline{1}, \underline{2}, 8$ & $99 \%$ & 3 & $1 \%$ & 4 & 192 \\
\hline 7 & $\underline{1}, \underline{2}$, & $99 \%$ & 4 & $1 \%$ & 3 & 121 \\
\hline
\end{tabular}

legend drug identification numbers:

- NHG-recommended drugs: 1-nifedipine.

- Asten formulary recomm. drugs: 1-nifedipine; 2-amlodipine.

- other drugs: 3-felodipine; 4-isradipine; 5-lacidipine; 6-lercanidipine; 7-mibefradil;

8-nicardipine; 9-nimodipine; 10-nisoldipine; 11-nitrendipine. 
table 5.4.f. Cholesterol inhibitors prescribed by individual physicians in a period of $\mathbf{4 2}$ months.

Varying selection of drugs of personal preference and other drugs.

\begin{tabular}{|c|l|l|l|l|l|l|}
\hline A-group & pers.pref. & $\%$ prescr. & other drugs & $\begin{array}{l}\% \\
\text { prescr. }\end{array}$ & $\begin{array}{l}\text { nr. diff. } \\
\text { drugs }\end{array}$ & $\begin{array}{l}\text { total nr. } \\
\text { prescr. }\end{array}$ \\
\hline GP 1 & $\underline{1}, 4$ & $98 \%$ & $\underline{2}$ & $2 \%$ & 3 & 123 \\
\hline 2 & $\underline{1}, \underline{2}, \underline{3}$ & $98 \%$ & 4 & $2 \%$ & 4 & 207 \\
\hline 3 & 1 & $100 \%$ & - & - & 1 & 28 \\
\hline 4 & $\underline{1}, \underline{3}$ & $99 \%$ & 5 & $1 \%$ & 3 & 80 \\
\hline 5 & $\underline{1}, 4$ & $100 \%$ & - & - & 2 & 34 \\
\hline 6 & $\underline{1}, \underline{2}, 4$ & $100 \%$ & - & - & 3 & 176 \\
\hline 7 & $\underline{1}, \underline{2}$, & $96 \%$ & $\underline{3}, 4$ & $4 \%$ & 4 & 233 \\
\hline
\end{tabular}

legend drug identification numbers:

NHG-recommended drugs: 1-simvastatin; 2-pravastatin.

Asten formulary recommended drugs: 1-simvastatin; 2-pravastatin; $\underline{3}$-fluvastatin. other drugs: 4-atorvastatin; 5-cerivastatin. 
table 5.5. Ranges of percentages of prescriptions for A-formulary and/or NHG recommended NSAIDs by GPs in the A-group in $\mathbf{4 2}$ months.

Total number 10034 prescriptions for NSAIDs.

\begin{tabular}{|l|l|l||c|}
\hline NSAID: & range \% prescr. & mean \% prescr. & range nr. prescr. \\
\hline diclofenac & $48-75$ & 63 & $3034-4741$ \\
\hline ibuprofen & $12-43$ & 25 & $301-1079$ \\
\hline nabumetone & $0-9$ & 2 & $0-181$ \\
\hline naproxen & $4-17$ & 9 & $36-154$ \\
\hline $\begin{array}{l}\% \text { A-formulary com- } \\
\text { pliance }\end{array}$ & $81-93 \%$ & $87 \%$ & $7071-8119$ \\
\hline $\begin{array}{l}\% \text { NHG *com- } \\
\text { pliance }\end{array}$ & $78-98 \%$ & $94 \%$ & $7357-9243$ \\
\hline
\end{tabular}

* inter-doctor variation in percentage of agreement with NHG-guidelines significantly beyond chance $(p<0.05$; chi-square test). 


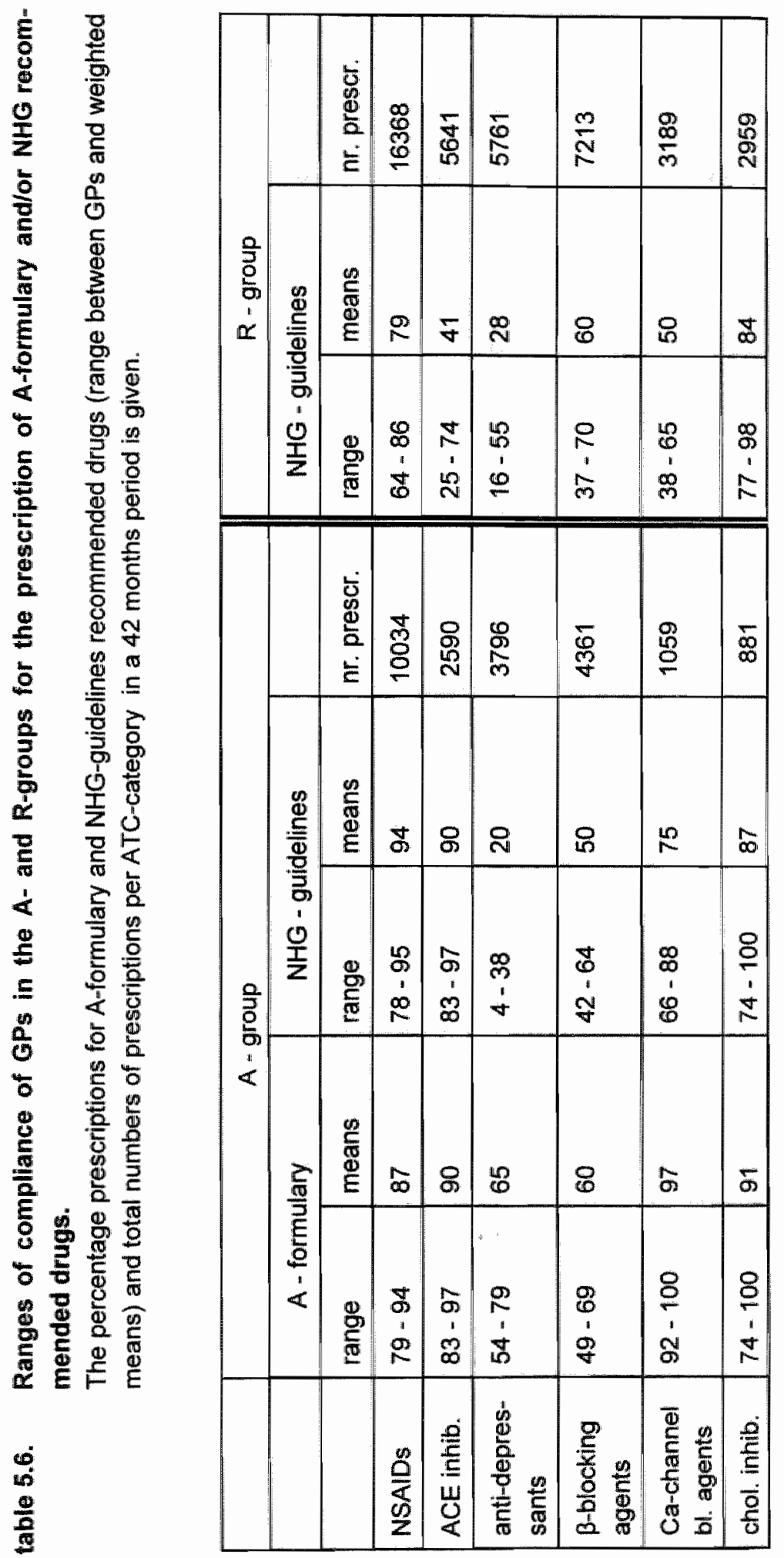


table 5.7 Coefficients of variation concerning prescription of drugs of personal preference by GPs in the A-viz. R-group over seven consecutive half year periods.

Ranges of cv's per drug and mean cv's per ATC-category (cf. Methods). A-formulary drugs: underlined; NHG-recommended drugs: bold type.

\begin{tabular}{|c|c|c|c|c|c|}
\hline & \multicolumn{2}{|c|}{ c.v. range } & & \multicolumn{2}{|c|}{ c.v. range } \\
\hline & A-group & $\overline{R-g r o u p ~}$ & & $A-$ group & $\bar{R}$-group \\
\hline \multicolumn{3}{|l|}{ NSAIDs } & \multicolumn{3}{|c|}{ BETA-BLOCKING AGENTS } \\
\hline diclofenac & $6-53$ & $12-34$ & propranolol & $15-66$ & $26-46$ \\
\hline diclof/misopr & 51 & $68-131$ & sotalol & $20-67$ & $15-39$ \\
\hline piroxicam & & $36-105$ & metoprolol & $14-94$ & $6-15$ \\
\hline meloxicam & & $106-219$ & atenolol & $11-63$ & $11-25$ \\
\hline ibuprofen & $30-103$ & $10-51$ & bisoprolol & $55-67$ & $6-28$ \\
\hline naproxen & $7-38$ & $15-55$ & pindolol & $6-63$ & \\
\hline tiaprofenic acid & & 40 & mean of category & 42 & 22 \\
\hline nabumetone & 40 & $72-123$ & & & \\
\hline azapropazone & & $0-51$ & & & \\
\hline mean of category & 42 & 66 & & & \\
\hline \multicolumn{3}{|l|}{ ACE-INHIBITORS } & \multicolumn{3}{|c|}{ CA-CHANNEL BLOCKING AGENTS } \\
\hline captopril & $15-84$ & $22-34$ & amlodipine & $21-122$ & $11-70$ \\
\hline enalapril & $21-87$ & $8-26$ & felodipine & & $25-51$ \\
\hline lisinopril & $42-69$ & $24-90$ & isradlipine & & 52 \\
\hline perindopril & $39-62$ & $17-67$ & Nicardipine & 65 & \\
\hline ramipril & 42 & $21-57$ & nifedipine & $9-53$ & $5-29$ \\
\hline fosinopril & & $49-126$ & lercanidipine & & 174 \\
\hline trandolapril & & 59 & mean of category & 52 & 62 \\
\hline quinapril & 56 & & & & \\
\hline mean of category & 52 & 45 & & & \\
\hline \multicolumn{3}{|l|}{ ANTI-DEPRESSANTS } & \multicolumn{3}{|c|}{ CHOLESTEROL INHIBITORS } \\
\hline imipramine & & 212 & simvastatin & $12-92$ & $6-24$ \\
\hline clomipramine & $33-121$ & $83-101$ & pravastatin & $50-96$ & $9-49$ \\
\hline amitriptyline & $45-89$ & $13-67$ & fluvastatin & $82-133$ & $30-72$ \\
\hline nortryptiline & & 265 & atorvastatin & 198 & $118-$ \\
\hline dosulepine & & 146 & mean of category & 104 & 54 \\
\hline maprotiline & 32 & $28-125$ & & & \\
\hline fluoxetine & $25-111$ & $20-66$ & & & \\
\hline paroxetine & $14-85$ & $27-79$ & & & \\
\hline fluvoxamine & $31-71$ & $28-68$ & & & \\
\hline moclobemide & 58 & & & & \\
\hline mirtazapine & & $57-66$ & & & \\
\hline trazodone & $12-49$ & & & & \\
\hline venlafaxine & & $22-95$ & & & \\
\hline mean of category & 51 & 96 & & & \\
\hline
\end{tabular}


table 5.8. Variety in prescription per ATC-category and overall;

comparison between data from A-group and from R-group.

- total numbers of prescriptions with percentage (weighted means) prescriptions of drugs of personal preference per group;

- prescribed numbers of different 'drugs of personal preference': ranges between individual GPs per group;

- prescribed numbers of all different drugs: ranges between individual GPs per group.

\begin{tabular}{|c|c|c|c|c|c|c|c|}
\hline $\begin{array}{l}\text { category } \\
\text { ATC-code }\end{array}$ & $\begin{array}{l}\text { NSAID"s } \\
\text { (M01A) }\end{array}$ & $\begin{array}{l}\text { ACE- } \\
\text { inhibitors } \\
(\mathrm{COSA})\end{array}$ & $\begin{array}{l}\begin{array}{l}\text { anti- } \\
\text { depress. }\end{array} \\
\text { (N06A) }\end{array}$ & $\begin{array}{l}\text { beta- } \\
\text { blockers } \\
(\operatorname{Co7} A)\end{array}$ & $\begin{array}{l}\text { Ca-ch. } \\
\text { blockers } \\
(\mathrm{CO} C \mathrm{C})\end{array}$ & $\begin{array}{l}\text { chol. } \\
\text { inhibitors } \\
\text { (C1DAA) }\end{array}$ & all drugs \\
\hline $\begin{array}{l}\text { ATC totall } \\
\text { mr. of drugs }\end{array}$ & 16 & 10 & 20 & 15 & 11 & 5 & 77 \\
\hline \multicolumn{8}{|l|}{ A-range } \\
\hline $\begin{array}{l}\text { total } \mathrm{nr} \text {. of } \\
\text { prescr. }\end{array}$ & 10034 & 2590 & 3796 & 4361 & 1059 & 881 & 22721 \\
\hline $\begin{array}{l}\% \text { prescr. } \\
\text { pers.pref. }\end{array}$ & $94 \%$ & $96 \%$ & $87 \%$ & $95 \%$ & $98 \%$ & $98 \%$ & $94 \%$ \\
\hline $\begin{array}{l}\text { nr. drugs of } \\
\text { pers. pref. }\end{array}$ & $2-5$ & $2-4$ & $3-6$ & $4-6$ & $2-3$ & $1-3$ & $17-24$ \\
\hline $\begin{array}{l}\text { all different } \\
\text { drugs prscr. }\end{array}$ & $7-11$ & $3-6$ & $7-12$ & $6-9$ & $2-4$ & $1-4$ & $31-42^{*}$ \\
\hline \multicolumn{8}{|l|}{ R-range } \\
\hline $\begin{array}{l}\text { total } \mathrm{nr} \text {. of } \\
\text { prescr. }\end{array}$ & 16368 & 5641 & 5761 & 7213 & 3189 & 2959 & 41131 \\
\hline $\begin{array}{l}\% \text { prescr. } \\
\text { pers. pref. }\end{array}$ & $92 \%$ & $98 \%$ & $88 \%$ & $89 \%$ & $88 \%$ & $98 \%$ & $91 \%$ \\
\hline $\begin{array}{l}\text { nr. drugs of } \\
\text { pers. pref. }\end{array}$ & $4-5$ & $3-7$ & $4-7$ & $3-5$ & $2-4$ & $2-4$ & $22-29$ \\
\hline $\begin{array}{l}\text { all different } \\
\text { drugs prscr. }\end{array}$ & $11-15$ & $6-8$ & $11-20$ & $8 \cdot 10$ & $5-10$ & $4-5$ & $48-67^{*}$ \\
\hline
\end{tabular}

* variation in number and range of prescribed drugs between A-group and R-group beyond chance ( $p<0.01$; chi-square test). 
table 5.9. Longitudinal mean compliance (\%) by GPs in the A-group with the A-formulary and with NHG-guidelines and by GPs in the R-group with the NHG-guidelines in seven consecutive half year periods and overall.

\begin{tabular}{|c|c|c|c|c|c|c|c|c|c|c|c|c|c|c|c|c|}
\hline periad & 199 & $6 / 1$ & 199 & $96 / 2$ & 190 & $7 / 1$ & 198 & $77 / 2$ & 195 & $8 / 1$ & 195 & $8 / 2$ & 195 & $9 / 1$ & ove & \\
\hline A-group & A 1 & $\mathrm{NHG}$ & A & $\mathrm{NHG}$ & A & NHG & A & NHG & A & NHG & A & NHG & A & NHG & & NHG \\
\hline NSAIDs & 87 & 94 & 88 & 92 & 85 & 91 & 84 & 92 & 87 & 94 & 88 & 94 & 90 & 95 & 87 & 94 \\
\hline ACE-inh. & 89 & 89 & 87 & 87 & 87 & 87 & 87 & 87 & 91 & 91 & 92 & 92 & 92 & 92 & 90 & 90 \\
\hline $\begin{array}{l}\text { anti- } \\
\text { depress. }\end{array}$ & 48 & 27 & 50 & 18 & 65 & 23 & 66 & 21 & 67 & 18 & 68 & 13 & 71 & 12 & 65 & 20 \\
\hline $\begin{array}{l}\beta \text {-block. } \\
\text { agents }\end{array}$ & 57 & 39 & 65 & 48 & 60 & 45 & 62 & 52 & 61 & 55 & 58 & 53 & 58 & 55 & 60 & 50 \\
\hline $\begin{array}{l}\text { Ca-entry } \\
\text { bl. agents }\end{array}$ & 83 & 60 & 84 & 60 & 83 & 68 & 83 & 69 & 96 & 77 & 98 & 78 & 98 & 69 & 97 & 75 \\
\hline cholinh. & 100 & 100 & 86 & 86 & 86 & 86 & 97 & 97 & 93 & 90 & 93 & 90 & 90 & 89 & 92 & 87 \\
\hline all drugs & 77 & 68 & 77 & 65 & 78 & 67 & 80 & 70 & 83 & 71 & 82 & 70 & 83 & 69 & 82 & 70 \\
\hline R-group & & $\mathrm{NHG}$ & & $\mathrm{NHG}$ & & NHG & & $\mathrm{NHG}$ & & $\mathrm{NHG}$ & & NHG & & NHG & & NHG \\
\hline NSAIDS & & 80 & & 81 & & 80 & & 77 & & 80 & & 80 & & 76 & & 79 \\
\hline ACE-inh. & & 55 & & 58 & & 56 & & 49 & & 47 & & 37 & & 39 & & 48 \\
\hline $\begin{array}{l}\text { anti- } \\
\text { depress. }\end{array}$ & & 35 & & 31 & & 35 & & 30 & & 31 & & 27 & & 26 & & 30 \\
\hline $\begin{array}{l}\text { B-block. } \\
\text { agents }\end{array}$ & & 55 & & 54 & & 52 & & 50 & & 47 & & 51 & & 47 & & 51 \\
\hline $\begin{array}{l}\text { Ca-entry } \\
\text { bl. agents }\end{array}$ & & 55 & & 54 & & 52 & & 50 & & 47 & & 51 & & 47 & & 51 \\
\hline chollinh. & & 95 & & 92 & & 91 & & 92 & & 82 & & 77 & & 81 & & 86 \\
\hline all drugs & & 63 & & 62 & & 61 & & 58 & & 56 & & 54 & & 53 & & 58 \\
\hline
\end{tabular}




\begin{tabular}{|c|c|c|c|c|c|c|c|c|}
\hline 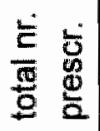 & $\frac{n}{n}$ & ำ & $\stackrel{n}{R}$ & $\stackrel{8}{8}$ & 串 & $\bar{m}_{m}^{\frac{6}{m}}$ & $\frac{5}{5}$ & 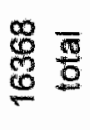 \\
\hline 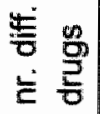 & $\stackrel{N}{\sim}$ & $\stackrel{\sim}{\sim}$ & 2 & $?$ & $\stackrel{N}{2}$ & $\stackrel{2}{\circ}$ & $\approx$ & \\
\hline 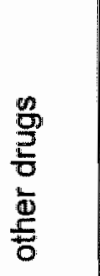 & $\begin{array}{l}m \\
m \\
F \\
\infty \\
\infty\end{array}$ & $\begin{array}{l}\stackrel{m}{\sigma} \\
\stackrel{\sigma}{\sigma} \\
=0 \\
\sigma \\
\infty\end{array}$ & 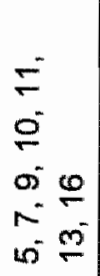 & $\begin{array}{l}= \\
= \\
0 \\
0 \\
\infty\end{array}$ & $\begin{array}{l}\frac{0}{2} \\
\mathbb{2} \\
= \\
\infty \\
0 \\
0\end{array}$ & $\begin{array}{l}\frac{N}{=} \\
=0 \\
\sigma \\
\infty \\
N \\
N\end{array}$ & $\begin{array}{l}0 \\
\infty \\
5 \\
5 \\
\infty\end{array}$ & \\
\hline 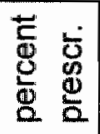 & के & ஓ̊요 & ๙̊ํ & $\frac{2}{\sigma}$ & $\frac{2}{\infty}$ & $\frac{\circ}{\sigma}$ & ๙ั & ๙ั้ \\
\hline 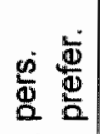 & $\begin{array}{l}\infty \\
=\infty\end{array}$ & $\begin{array}{l}m \\
r \\
r\end{array}$ & $\begin{array}{l}\omega^{4} \\
\sim \infty \\
=\omega^{\circ}\end{array}$ & $\begin{array}{l}m \\
=10\end{array}$ & $\begin{array}{l}m e \\
\sim \\
N\end{array}$ & $\begin{array}{l}m \\
\sim\end{array}$ & 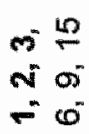 & \\
\hline 용 응 & $\frac{-}{0}$ & $\frac{N}{0}$ & $\frac{m}{0}$ & $\begin{array}{l}+ \\
0 \\
0\end{array}$ & $\frac{0}{0}$ & $\frac{0}{0}$ & $\frac{1}{0}$ & 恖 \\
\hline 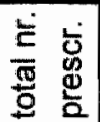 & $\stackrel{\mathscr{O}}{\check{C}}$ & \& & $\frac{n}{n}$ & $\frac{\text { V̀ }}{N}$ & $\mathscr{8}$ & 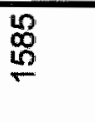 & 帒 & $\stackrel{\Phi}{8}$ \\
\hline $\begin{array}{ll}\frac{4}{0} & 0 \\
\end{array}$ & $\stackrel{\rho}{2}$ & 운 & $\infty$ & $F$ & $\infty$ & $\sigma$ & $N$ & \\
\hline $\begin{array}{l}\frac{n}{0} \\
\frac{2}{0} \\
\frac{5}{6} \\
\frac{5}{5}\end{array}$ & $\begin{array}{l}\frac{0}{\pi} \\
= \\
5 \\
5\end{array}$ & $\begin{array}{l}\sigma^{-} \\
\sigma^{\circ} \\
\infty \\
\infty \\
0^{\circ} \\
+5\end{array}$ & $\begin{array}{l}m \\
\sigma^{\circ} \\
\infty \\
0 \\
\omega^{\infty} \\
m\end{array}$ & $\begin{array}{l}0 \\
0 \\
0 \\
\infty \\
\infty \\
0 \\
0\end{array}$ & $\begin{array}{l}= \\
\sigma \\
\infty \\
\min \\
\min ^{\circ}\end{array}$ & $\begin{array}{l}m^{-} \\
\infty \\
n^{-} \\
\infty^{-} \\
m^{-}\end{array}$ & $\begin{array}{l}= \\
\text { का } \\
\text { in }\end{array}$ & \\
\hline
\end{tabular}

는

8

링

a

$\frac{8}{5}$
$\frac{5}{8}$
5
5

8

\begin{tabular}{|c|c|c|c|c|c|c|c|c|}
\hline $\begin{array}{ll}\frac{\pi}{8} & 5 \\
\frac{8}{9} & 8 \\
2\end{array}$ & $\begin{array}{l}00 \\
0 \\
0\end{array}$ & o̊ & \%े & 8 & $\frac{2}{\sigma}$ & $\frac{9}{\infty}$ & ㅇํㅇ & $\frac{8}{0}$ \\
\hline 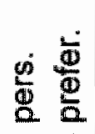 & $\begin{array}{l}\text { का } \\
\text { Ni } \\
-10^{-1}\end{array}$ & $\frac{m}{n}$ & $\underset{-1}{N}$ & $\begin{array}{c}m \\
-1 \\
-1\end{array}$ & $\begin{array}{l}N ! \\
-1\end{array}$ & il & $\begin{array}{l}m \\
-1 \\
-1\end{array}$ & \\
\hline$<\frac{0}{2}$ & $\frac{\pi}{0}$ & $N$ & $m$ & $\nabla$ & 10 & 0 & $N$ & $\frac{\frac{5}{8}}{\mathscr{E}}$ \\
\hline
\end{tabular}
$\frac{3}{2}$ 

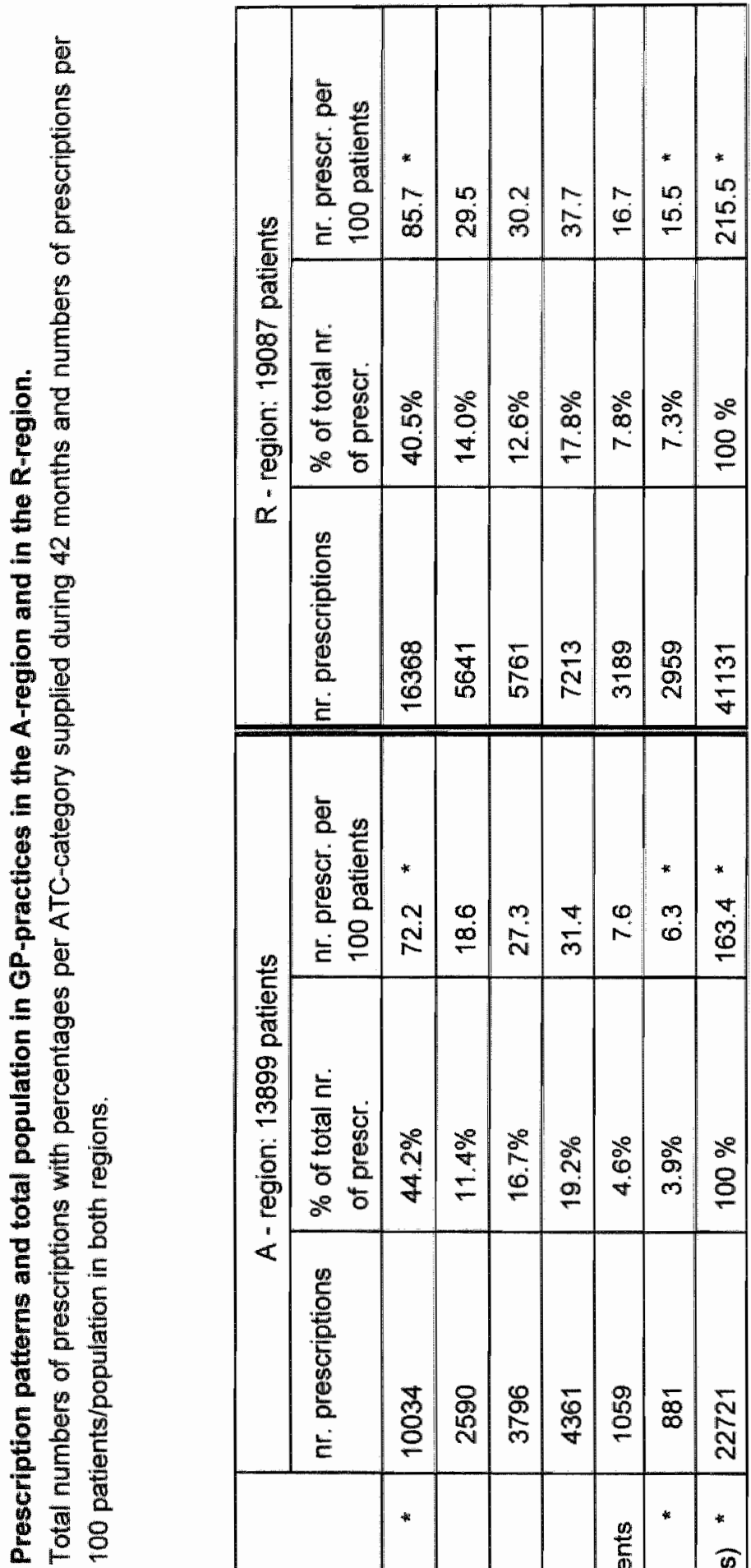

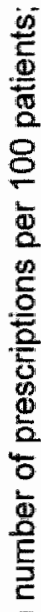

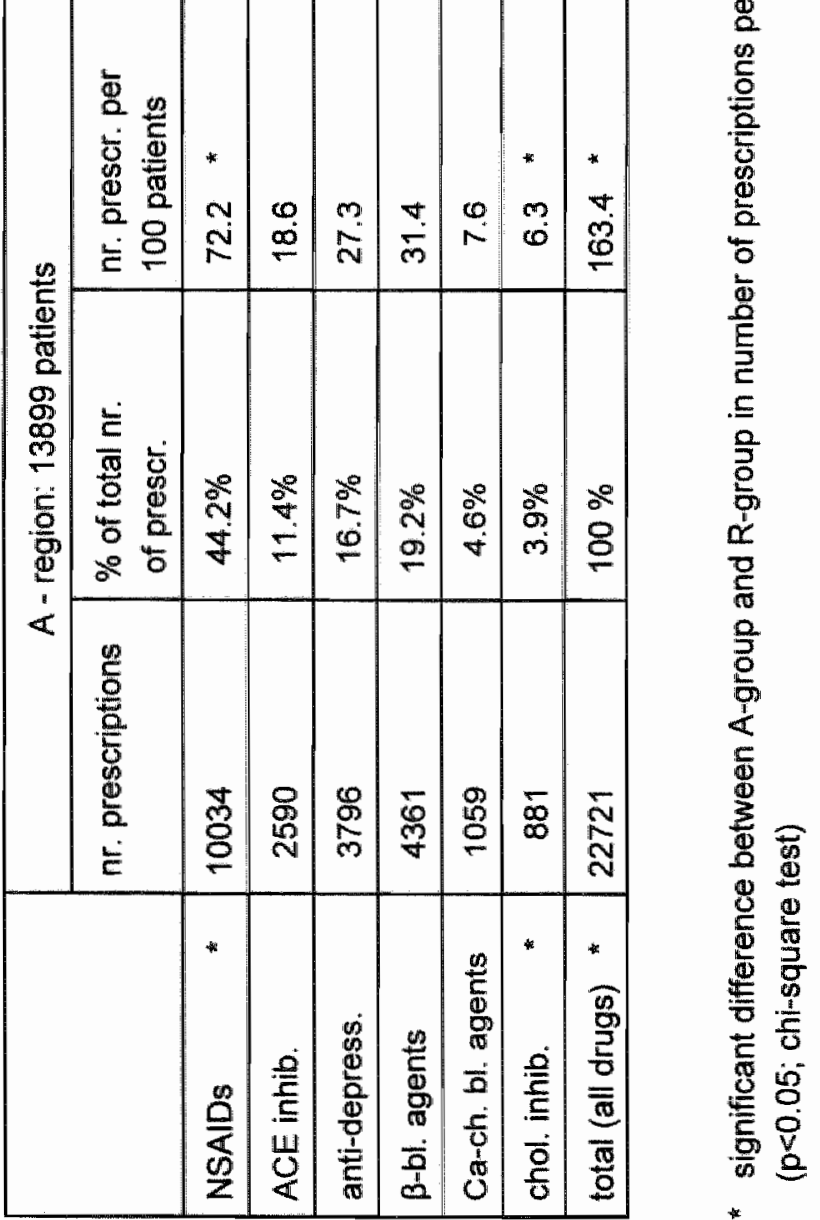




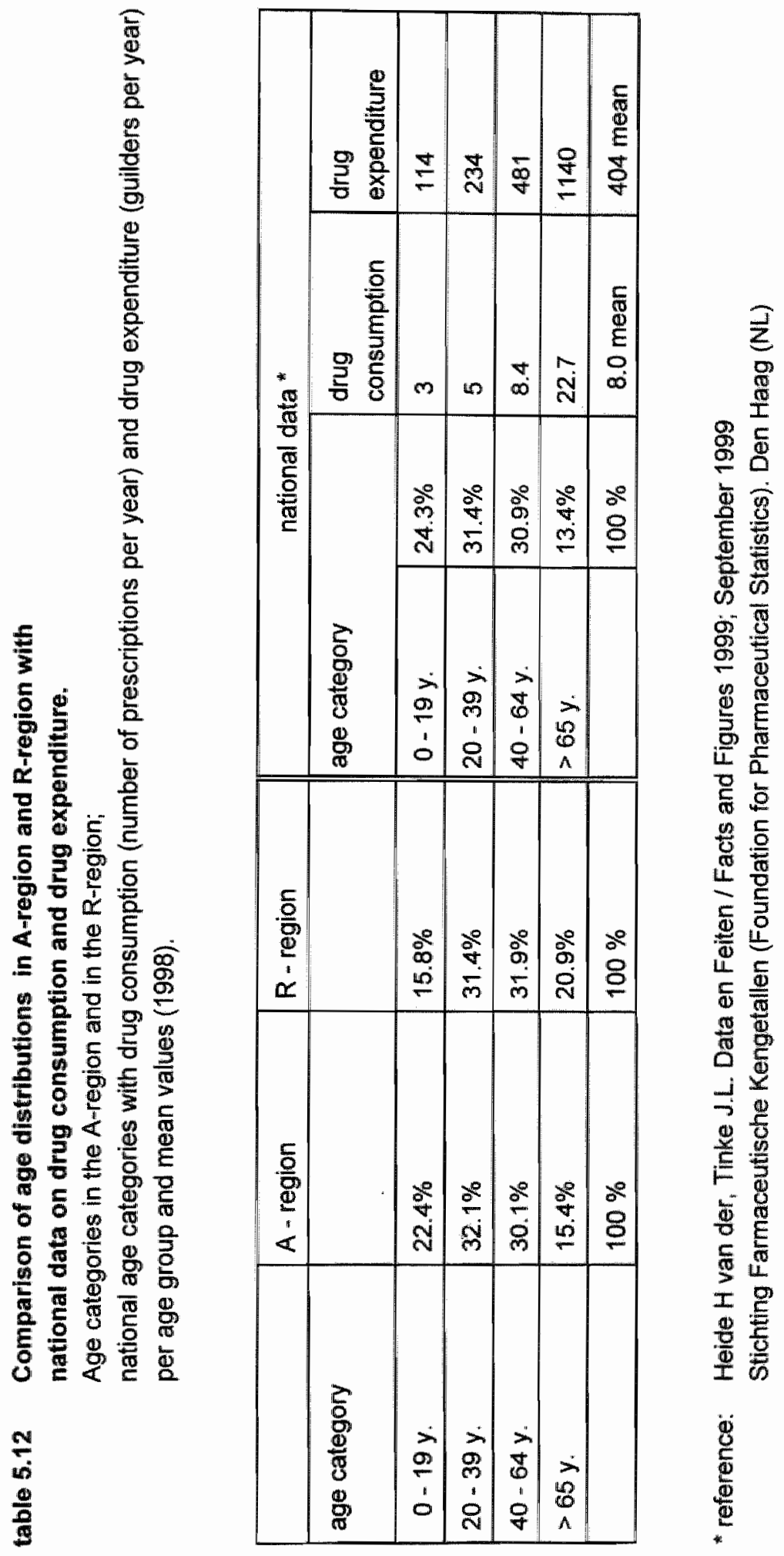




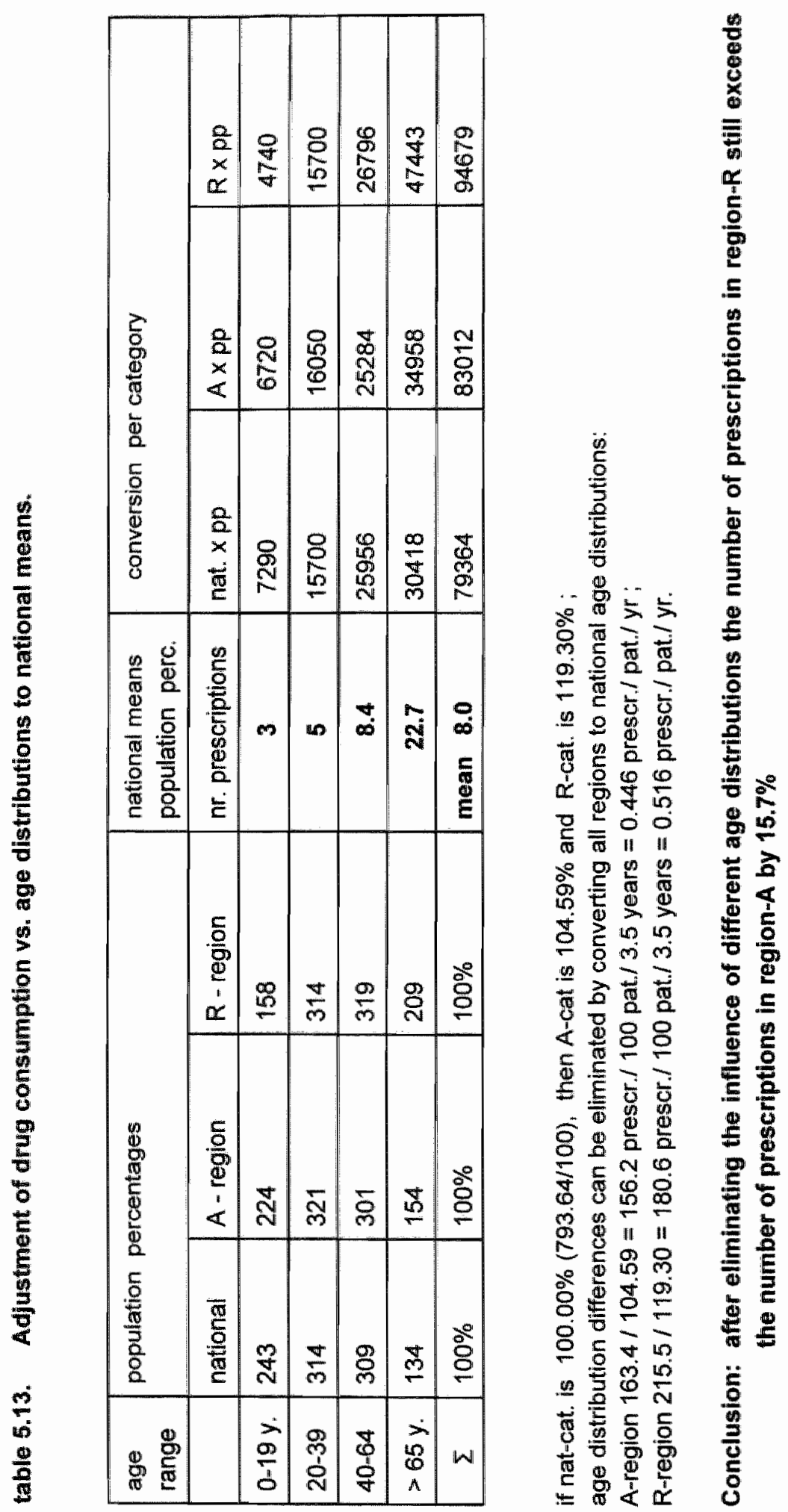


Fig. 5.1 - 5.7. Graphical presentations of prescriptions of different general practitioners in the A-group.

legends to the figures (cf. Methods):

figs. 5.1.N $-5.7 . \mathrm{N}$

Prescriptions of NSAIDs.

Numbers of prescriptions by individual physicians GP1 - GP7 for specific NSAIDs in seven consecutive six months periods.

figs. 5.1.AC - 5.7.AC

\section{Prescriptions of ACE-inhibitors.}

Numbers of prescriptions by individual physicians GP1 - GP7 for specific ACEinhibitors in seven consecutive six months periods.

figs. 5.1.AD - 5.7.AD

Prescriptions of anti-depressants.

Numbers of prescriptions by individual physicians GP1 - GP7 for specific antidepressants in seven consecutive six months periods.

figs. 5.1.B - 5.7.B

Prescriptions of beta-blocking agents.

Numbers of prescriptions by individual physicians GP1 - GP7 for specific betablocking agents in seven consecutive six months periods.

figs. 5.1.Ca - 5.7.Ca

Prescriptions of calcium-channel blocking agents.

Numbers of prescriptions by individual physicians GP1 - GP7 for specific calcium-channel blocking agents in seven consecutive six months periods.

figs. 5.1.Ch - 5.7. Ch

Prescriptions of cholesterol inhibitors.

Numbers of prescriptions by individual physicians GP1 - GP7 for specific cholesterol inhibitors in seven consecutive six months periods. 

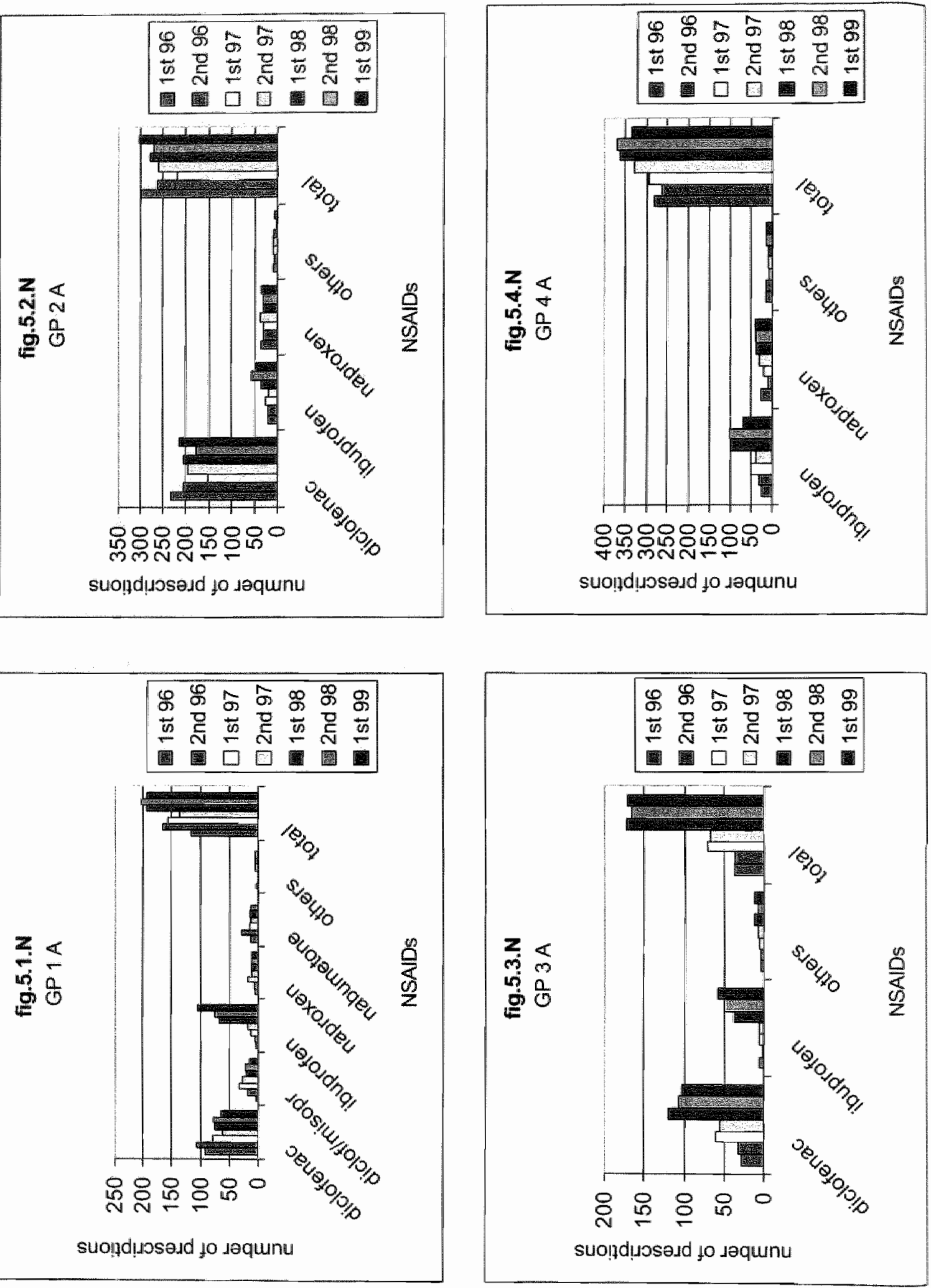

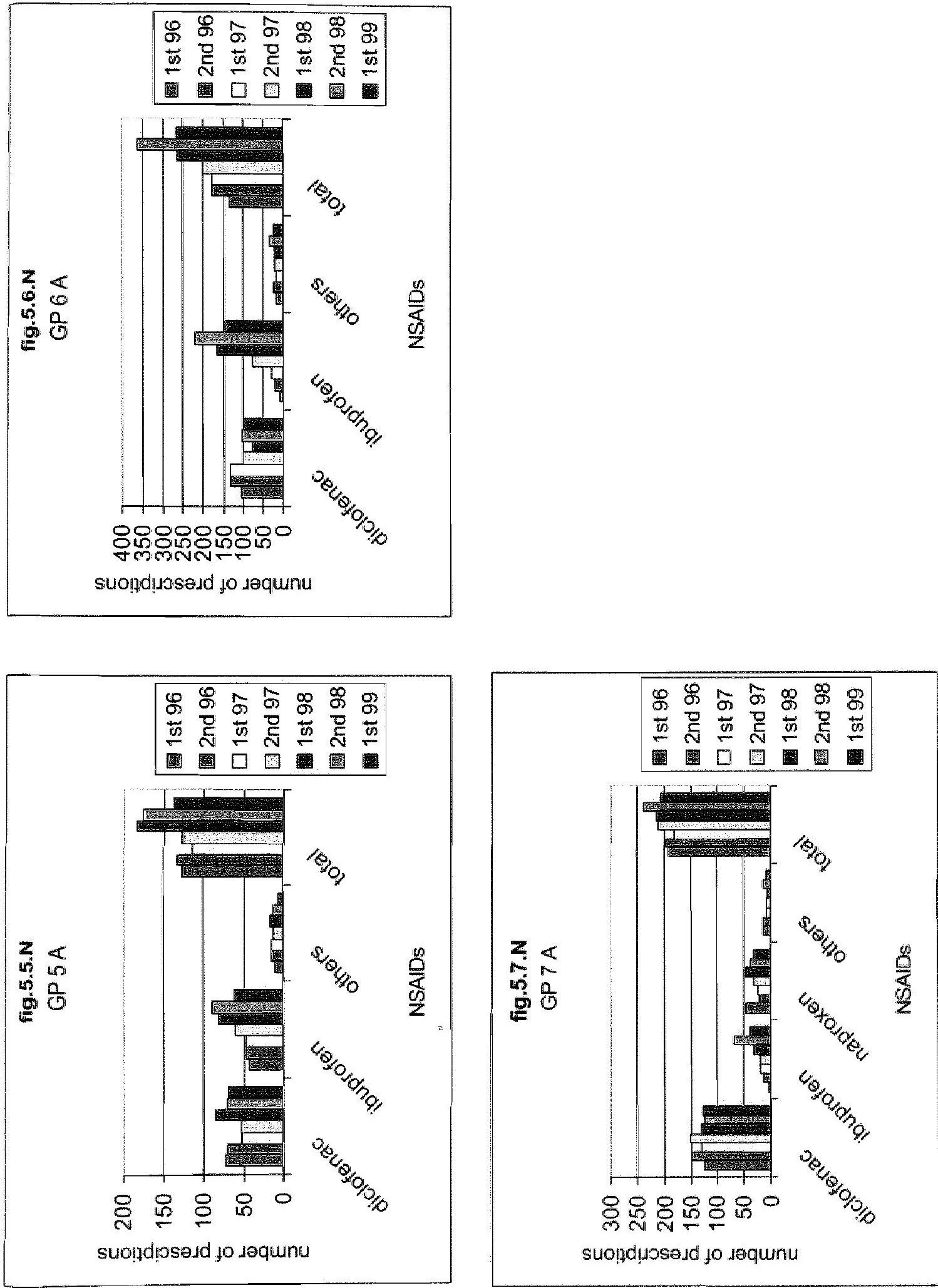

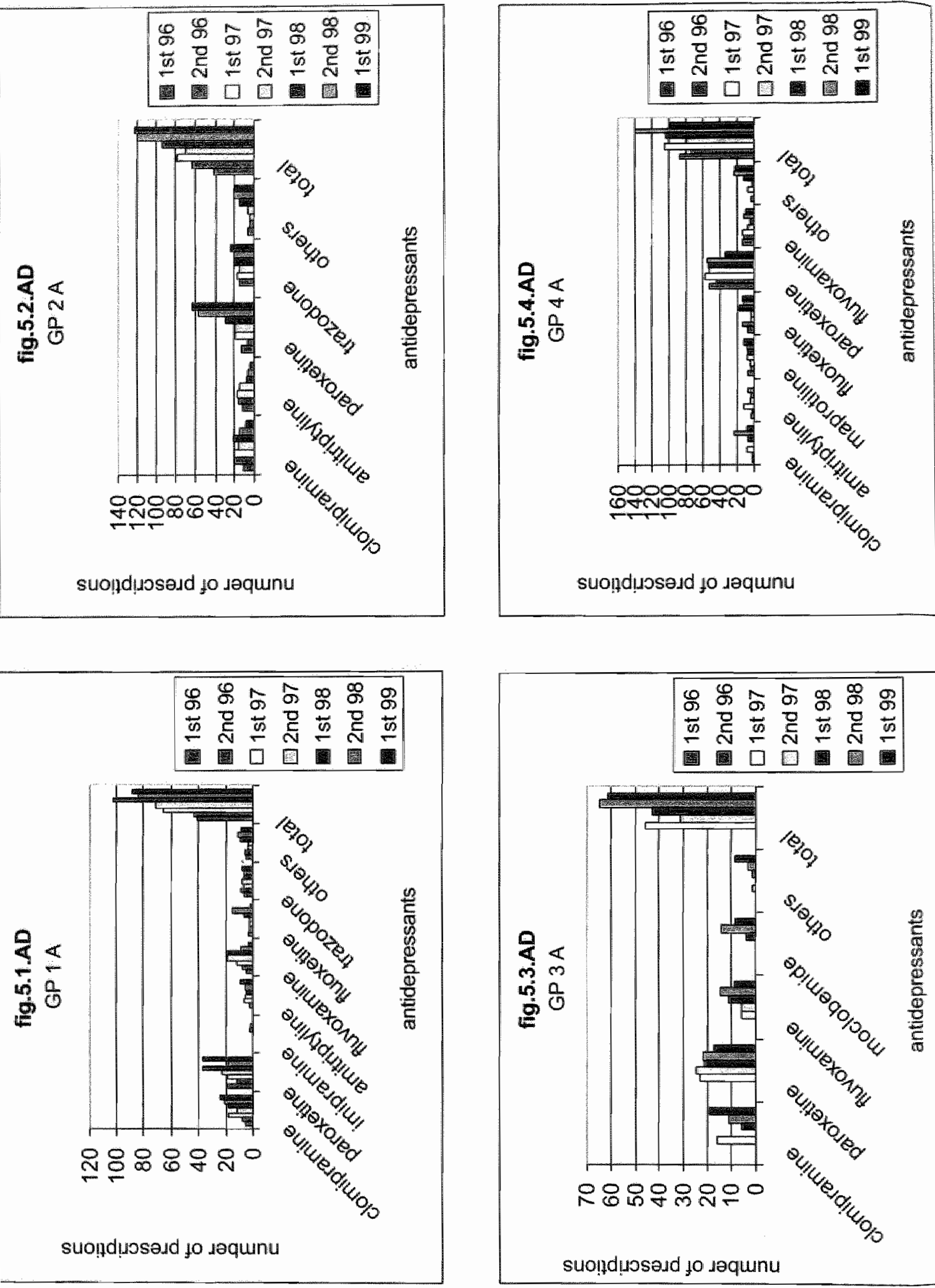

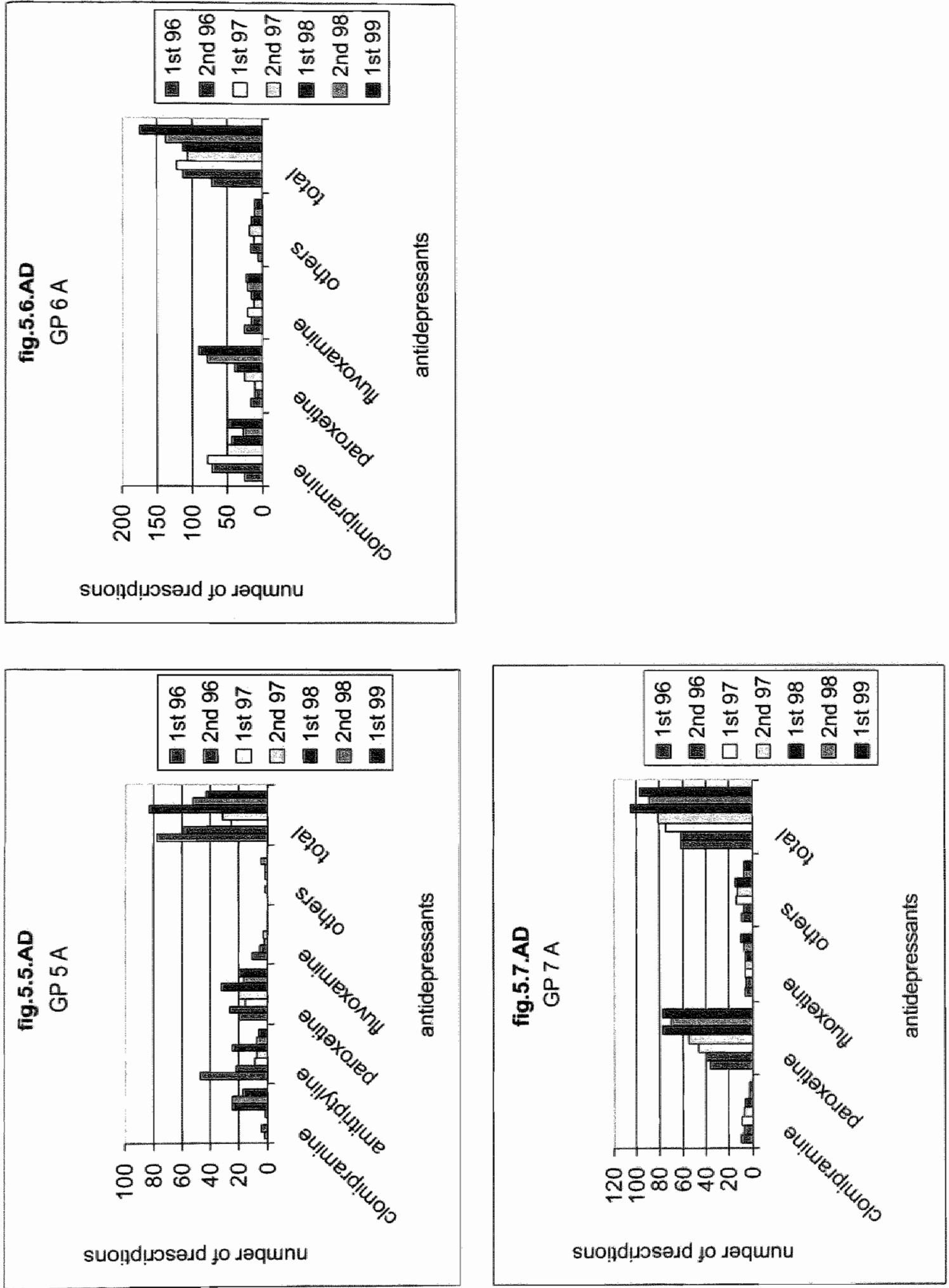

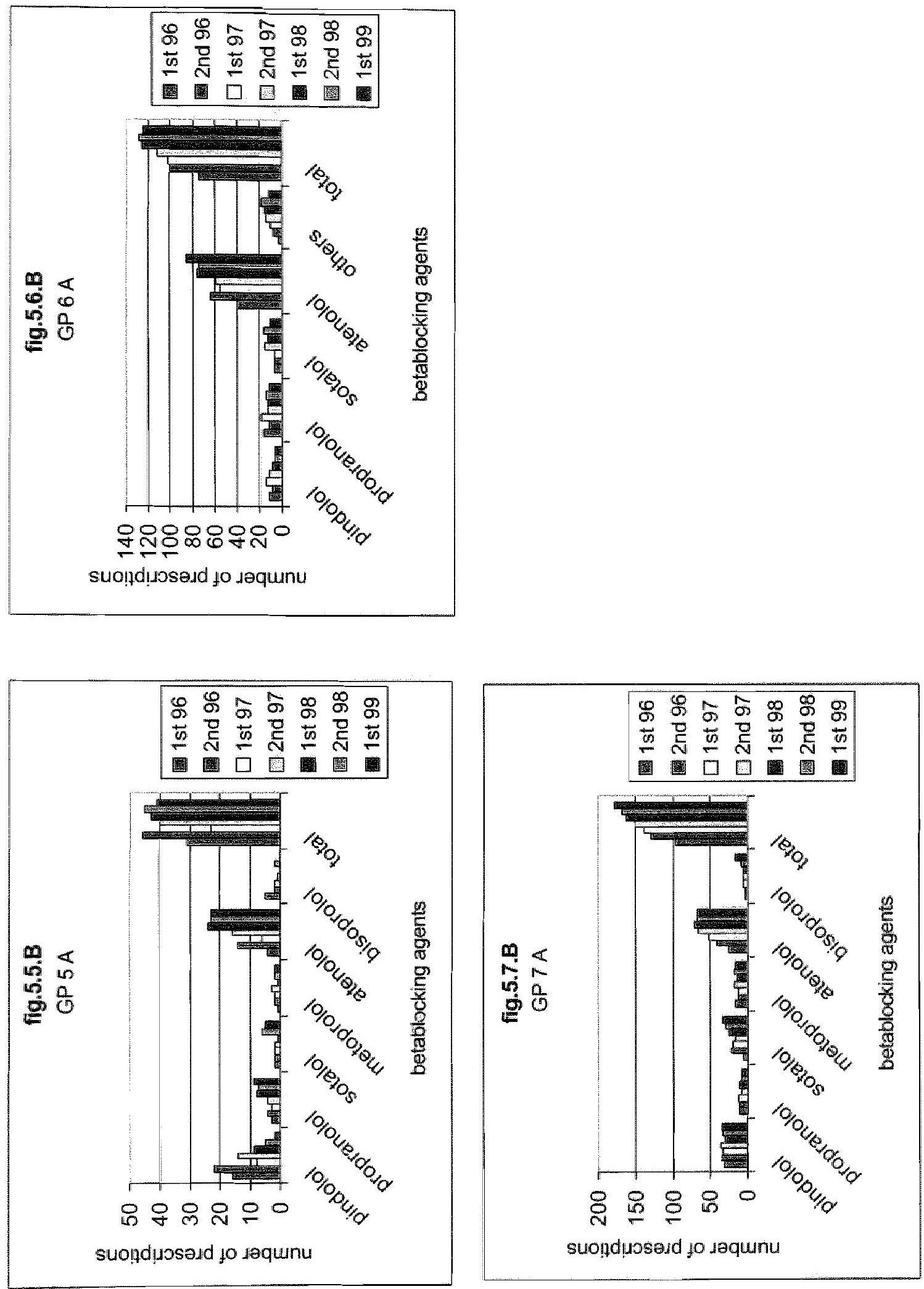

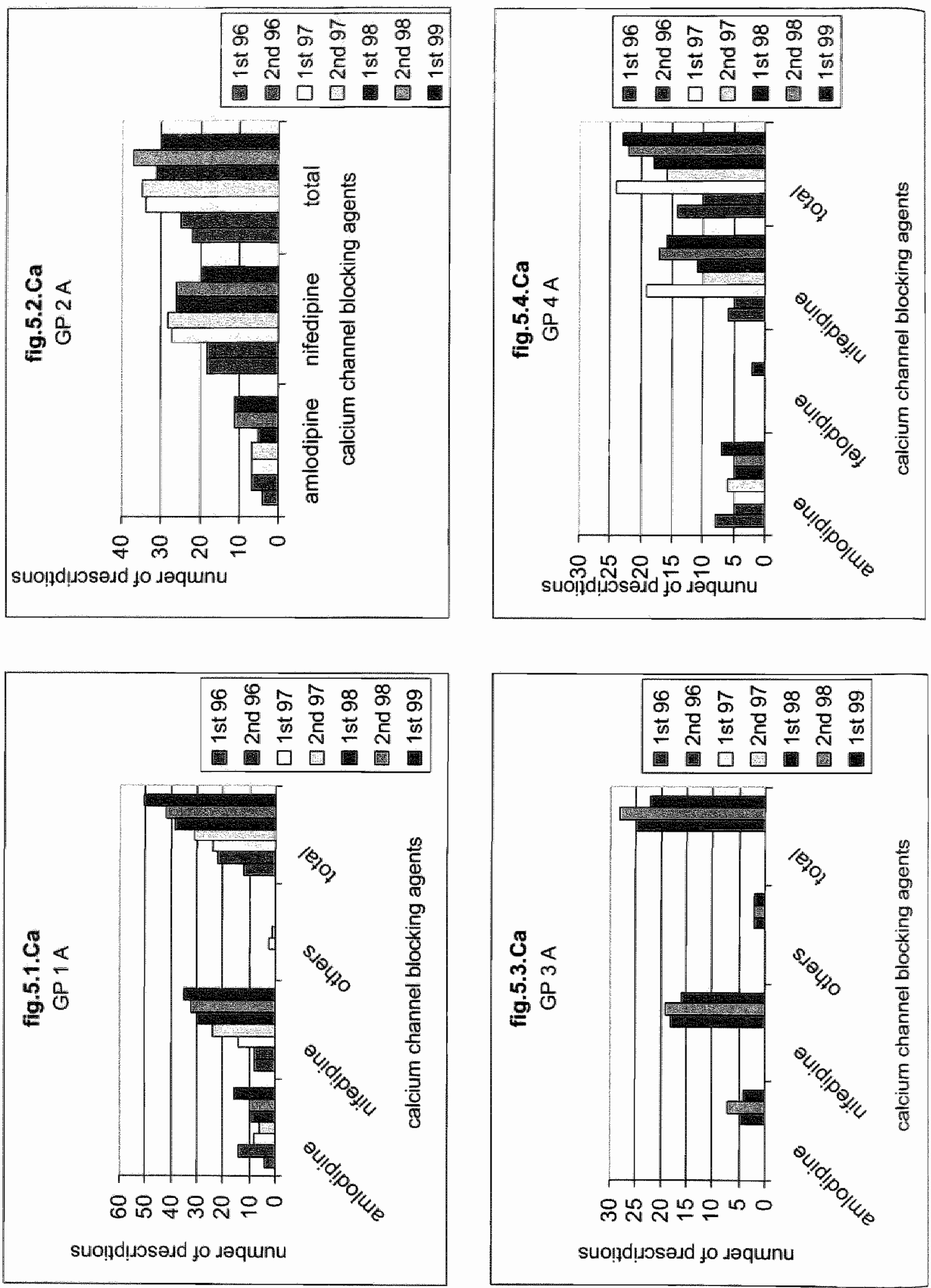

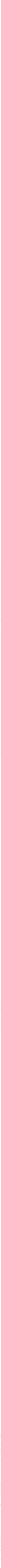

CHAPTER VI

\section{EVALUATION OF LONGITUDINAL CHANGES IN DRUG PRESCRIPTION}

A QUALITATIVE STUDY ON PRESCRIBING IN GENERAL PRACTICE 
Introduction. The process of drug selection by general practitioners has been the subject of many studies $(17,38,68,72,124)$, aiming at improved prescription behaviour (73). Good prescribing is generally considered to be rational, effective, efficient and efficacious (113). Moreover, prescription protocols should be standardised and based both on evidence and on long-term experience $(125,126$, 127). The diversity of prescribed drugs, different chemical entities, should be limited in order to avoid confusion. For individual prescription an appropriate choice out of this limited number of drugs must be made (64). The medication must be safe, i.e. taking the individual properties of the patient into account, he/she should be exposed to the lowest possible risks (128). Finally, when suitable drugs are fully interchangeable, the cheapest one must be selected $(128,129)$. All these aspects receive some attention from physicians when choosing drugs for the treatment of their patients. Taking this into account many GPs developed a 'personal evoked set' from which the majority of their prescriptions is taken (36). In the course of time, however, different drugs are sometimes chosen under comparable circumstances. Changing preference for certain drugs may be due to the introduction of newer drugs in the personal evoked set at the expense of older ones or as a an addition to the evoked set. It could also happen that the order of preference of listed drugs were changed. Individual GPs can decide to change every moment that they choose to prescribe. Instead of the introduction of 'personal evoked sets' some groups of GPs prefer guidelines for prescription leading to agreement on a general common formulary. The Dutch College of General Practitioners (NHG) published national guidelines for the treatment of a number of common diseases including recommendations for pharmaco-therapy. New agreements on behalf of the guidelines also lead to changes in prescription behaviour (chapters IV and V).

We studied the prescription behaviour of GPs in two groups, i.e. one group (audit group; A-group) where agreements existed on prescription from a common formulary and a reference group (R-group) where no such agreements had been made (chapters IV and $V$ ). In the R-group a total number of 41,131 prescriptions were included in the study; the number of prescriptions in the A-group amounted to 22,721. Both short term and long term changes in preferences of each individual physician were registered. Short term changes were often seen with newly licensed drugs whereas long term changes were primarily observed with drugs about which experience during a longer period was available. Although in some categories drugs were to some extent prescribed in agreement with national guidelines (NHG), also within these categories we observed different preferences between prescribers.

Assuming that these changes in some way or other influenced the quality of 
medical treatment it might be important to obtain insight in the underlying reasons of each individual GP for changing prescription habits. It may also be supposed that instability of prescription has a confusing effect on the building of cumulative experience and expertise of the prescribers. As it must be assumed that decisions for changing prescription behaviour are based on good medical practice, insight in the underlying reasons for changing preferences may contribute to the development of more consistent and rational prescription behaviour. Therefore, in order to provide information leading to a more consistent and rational prescription behaviour we retrospectively studied the motives for the observed longitudinal changes in prescription policy. This was realised by interviews with the individual GPs about their prescription patterns from the preceding three and a half years. as they were found and elucidating both the objective and the subjective reasons for changes in prescription policy in good cooperation with each of the GPs.

\section{Methods}

After collection of prescription data from seven consecutive half year periods, each of the GPs was retrospectively informed about the study. All fourteen GPs of the A-group and the R-group were asked for retrospective evaluation in an individual interview. One of the GPs in the A-group had moved to a new practice in the Netherlands. The new GP who recently joined the A-group was interviewed instead about her experiences in this group as a beginner. All accepted the invitation for the interviews and granted permission for the anonymous publication of their prescription pattern in this thesis and in scientific journals. They were highly interested in the results of our data collection. To each physician his individual prescription patterns from the studied six ATC-categories over the preceding three and a half years were revealed and the collected data were discussed with each individual prescriber. For this purpose we composed guidelines for discussion (table 6.1) in accordance with considerations described by other authors $(5,15)$. In the A-group we added four special questions about the PTAM-agreements and the formulary (table 6.1, additional questions for group A). All interviews, the processing of the data and concerning correspondence were performed by the same person, i.e. the author. Afterwards every GP checked his answers as they had been written down during the interview. Based on these answers we performed our evaluation study classifying the results of the individual interviews according to the following items:

- (Un)awareness of prescribing. In the interview the GP was questioned on his subjective degree of awareness on each prescription/selection of drugs and on changes in the selection pattern on retrospective observation. Moreover, we discussed what motives beyond the GP's awareness might have played a role. 
- Items mentioned to cause changes in prescribing. The GP was confronted with all changes in his prescription pattern over the preceding three and a half years. He was asked whether he recognised these patterns. His comments were collected and discussed.

- Items relevant to maintain stability of prescription. We registered all reasons for stable prescription patterns, as they were mentioned in writing or speech by the GP while studying his own prescription patterns.

- Items with and without recognised influence on prescription. A number of questions on possible influences on prescription was answered by the GPS and additional influences mentioned by them. The given answers were extensively discussed. About all influences the GP was asked for whether they affected his prescribing behaviour.

- Maintenance and development of professional pharmaco-therapeutic expertise and of professional education. In this section attention was payed to the scientific literature indicated to be read by the GP and to his own policy of keeping up with current therapeutic developments.

- 'Bottlenecks'. The 'bottlenecks' in prescribing as they were mentioned by the GPs during the interviews were discussed and described in this section.

- Answers to the additional questions for group A. The answers given on extra questions for the GPs of the A-group were discussed and registered.

\section{Results}

Each GP participated in retrospective evaluation by granting an extensive oral interview along the guidelines given in table 6.1. Seven GPs from the R-group and also seven GPs from the A-group have been interviewed. After interviewing the GPs from the A-group it appeared that their answers and comments were almost mutually identical. For an explanation they referred to the strong prescription discipline and frequent mutual consultation in this group.

The results of the interviews are systematically presented:

(Un)awareness of prescription (table 6.1.a). Before being faced with a detailed survey of their prescriptions during the past three and a half years, four of the GPS of the Reference-group predicted to be fully aware of their own prescription pattern, but during the interview two of them were surprised by the results and so suggest a certain degree of unawareness. Three GPs said not to be able to predict their own prescription reviews which was affirmed by their reactions during the interview.

The basic idea of the GPs in the A-group was that they were all well aware of their prescription choices. One GP said to be surprised by the number of (repeat-) prescriptions for diclofenac/misoprostoll (a relic from a preceding period of a 
personal preference for this combination) and by the decrease of prescriptions for beta-blocking agents which appeared to be more and more substituted by ACEinhibitors. Another GP said to be surprised that not all diclofenac had been replaced by ibuprofen.

Items mentioned to cause changes in prescribing (table 6.1.b). All GPs in the $R$-group showed changing prescription behaviour in the course of the preceding three and a half years: e.g. increase or decrease of the number of prescriptions for piroxicam, meloxicam, nabumetone, fosinopril and atorvastatin. Trial and error concerning the prescription of newly available drugs was indicated by all seven GPs in the R-group to be a reason for temporarily changing drugs preferences (table 6.2). Trial of new drugs was said to be stimulated by own medical curiosity and sometimes by presents of the pharmaceutical industry. 'Error' was recognised when side effects of the drug under trial turned out to be inconvenient or the expected greater effectiveness failed to occur. Five GPs in the R-group explicitly specified some of these trials as stimulated by pharmaceutical industries (table 6.2). However, we could not establish a clear relation between the number of drug trials, whether or not on request of a pharmaceutical company, and the attitude of the GPs towards visits of medical representatives.

A minority of the GPs in the R-group spontaneously mentioned some clearly defined reasons for an ever growing number of prescriptions for NSAIDs and ACE inhibitors such as a proportional increasing number of elderly patients, longer waiting lists for hospital admission for e.g. hip joint operations or cardiac surgery and a trend towards more and more early discharges from hospital. Three GPs explicitly pointed at the growing tendency to diagnose and medically treat depression as a reason for the increasing numbers of prescriptions for antidepressants (table 6.2).

Also in the A-group changing prescription behaviour was observed in the patterns of all GPs such as steadily changing preferences for e.g. ibuprofen, diclofenac, captopril, paroxetine, fluvoxamine, amitriptyline, nifedipine and simvastatin. All changing preferences were explained by changes in the common formulary. PTAM-discusions and agreements and adherence with NHG-guidelines were mentioned as the only reason for these changes. This was illustrated by e.g. the following remarks which were noted during the interviews:

- $\quad$ "ibuprofen-prescriptions increase at the expense of diclofenac, because it is now our first choice NSAID";

- "fluvoxamine prescriptions decrease, and paroxetine prescriptions increase, because it was decided (PTAM) that paroxetine became our first choice";

- "heart failure is now mentioned in the NHG-guideline as an indication for prescription of ACE-inhibitors"; 
"some time ago cholesterol-inhibiting medication was rarely started by the general practitioners in this region but due to changed NHG-guidelines there is an increasing number of these prescriptions".

Items mentioned to maintain stability of prescription (table 6.1.c). Next to changes in prescription policy, all GPs in the R-group also showed stable prescription patterns for some drugs, e.g. diclofenac, simvastatin, metoprolol, atenolol and enalapril. The main reason for this policy was the safety experienced by the GP over a longer period of time while prescribing these drugs. This could be interpreted as a successful 'personal trial'. The confirmation of own choices by national guidelines, PTAMs, satisfied patients, experienced effectiveness and specialists' prescriptions were spontaneously mentioned as good reasons for stable prescribing, however, by a minority of the GPs. Three GPs mentioned their own conservative attitude towards prescribing as a reason for stability (table 6.2). In the A-group stable prescription patterns were seen for $\mathrm{eg}$. diclofenac, fluvoxamine, paroxetine, atenolol, amlodipine and atorvastatin. As main reasons for stability were again mentioned PTAM-agreements (table 6.2) often confirming an earlier made decision for drugs of choice that was already a drug of preference, next to a stable amount of repeat-prescriptions for patients who were satisfied with the use of drugs that were a former formulary choice.

Items with and without recognised influences on prescription behaviour (table 6.1.d). Aspects that could affect prescription behaviour were discussed with each of the GPs. Their comments could be summarised as follows:

- Recognised effectiveness, safety and routine were confirmed by all prescribers in the R-group to affect their prescribing behaviour (table 6.3.a). The GPs of the A-group mentioned the effects of discussions about effectiveness, safety and routine behaviour in their monthly PTAM (table 6.3.b). They recognised that prescription routine is hard to change, but the gradual changes as shown in the patterns are feasible results of discussions. The computerisation of the formulary has helped a great deal to introduce and maintain the PTAM-agreements in daily practice.

- Own experience and information by medical representatives were confirmed to have influence on prescribing habits by five GPs of the R-group, but two GPs denied the influence of the latter item (table 6.3.a). The influence of the pharmaceutical industry was generally mentioned as an easy way of information about new drugs and two GPs recognised the influence on specific items in their own prescription patterns by industry attentions/presents offered to them (table 6.3.a). All GPs in the R-group said to be aware of the subjective character of the information given by medical representatives. Five GPs denied the influence of industry presents and some of them memorised their clear refusal of some trials 
for this very reason.

Invariably own experience in the A-group was seriously discussed in PTAM (table 6.3.b). The fact, that consideration of every individual GP's own experience was part of the discussion was mentioned as an important support for the ready acceptation of (new) formulary-agreements. By common agreement only the pharmacists of the group and none of the GPs received visits from medical representatives. Information provided by the latter was forwarded with comments by the pharmacists. Direct influence on prescription by visits of medical representatives of the pharmaceutical industry was thus avoided.

- NHG-guidelines, professional literature, professional education and pharmacists (tables 5.3.a and 5.4). Objective sources that mean to be of great influence, such as NHG-guidelines, professional literature, professional education and pharmacists in or outside PTAMs, were more or less recognised for their effects by four GPs in the R-group. The other GPs did not give them the credit for their efforts (130). Together a total number of fourteen different literature sources were mentioned to be of interest. However, many of these were consulted by one single GP in the group. Forwarding of information from these sources was not mentioned.

In the A-group the opinion concerning NHG-guidelines, professional literature, professional education and the teaching role of the pharmacists was unanimous (tables 5.3.b and 5.4). The NHG-guidelines were mentioned as the leading basis in PTAMs. The GPs of the A-group read professional literature, but they did not mention as many journals as their colleagues in the R-group. The opinion of the group was that one should read as a targeted research, or very little to none, because randomly reading could possibly have the same effect as information from pharmaceutical companies: a narrow and distorted view. The GPs in the Agroup stated that the pharmacists had proved themselves as the drug specialists and that they read the professional literature as a targeted research for every single PTAM subject. They explicitly gave them the credit for their better pharmaco-therapeutical education and knowledge and did not try to equal or outrun them. They deliberately sought a pharmacist's assistance and support for these reasons. Moreover, objective professional education was better and more frequently followed in the A-group. Mutual education of colleagues was practised on a regular basis.

- Side effects are mentioned by seven GPs of the R-group to have influence on prescribing patterns (table 6.3.a). All GPs reported personal experience with side effects. Some these were so dramatic that the number of prescriptions for specified drugs had been halved (see also chapter IV, figs. NSAIDs 4.4 and 4.5) or trials were stopped (see ch.IV, figs. NSAIDs 4.2 and 4.3).

The GPs of the A-group evaluated and compared literature about side-effects with 
their own experiences with side-effects which were monthly discussed in the PTAMs (table 6.3.b). Even in case of a pharmaco-therapeutic accident, the GPs tended to keep with their PTAM-agreements, because they felt that these were based on good reasons and solid experience.

- Contra-indications. The influence of contra-indications for prescription of specified drugs was positively confirmed by four GPs in the R-group (table 6.3.a). Three of them also explicitly mentioned consideration of pharmaco-kinetic properties. Although not always mentioned, these influences were never denied. No explicit examples were given.

In the A-group contra-indications and pharmacokinetic properties are part of the PTAM-discussions as they are part of the NHG-guidelines (table 6.3.b).

- Repeat-prescriptions following medication originally initiated by medical specialists, other GPs or dentists, were six times confirmed in the R-group to have influence (table 6.3.a). Nevertheless, studying all prescription patterns, no mutual similarity was found. It might therefore be supposed that repeat-prescriptions are of lesser importance for their individual prescription patterns than was suggested by the answers of six GPs. One GP denied that repeat prescriptions affected his individual prescription behaviour.

In the A-group repeat-prescriptions, e.g. from hospital consultants, were readily recognised by the GPs in their individual patterns as prescriptions differing from the formulary (table 6.4.b). When a patient is treated by a medical specialist, the repeat-prescriptions are prescribed by this specialist. Only after discharge from the specialist's supervision, patients return to the GP for further treatment and either repeat-prescriptions will be continued or drugs will be prescribed by the GP in line with the formulary.

- Dosage forms and cost of medication. Six GPs of the R-group said that the convenience and ease of dosage-forms actually affected their prescription behaviour (table 6.3.a). A broad variety of different dosage-forms with a certain chemical entity, e.g. effervescent tablets, injections and/or combination-preparations, were reported to influence the choice of five out of seven GPs. As a reason for this influence an increasing probability of better compliance by the patient was mentioned. Increasing or changing the variety of dosage-forms is a well known strategy by pharmaceutical industries to keep their market share after expiration of the patent emphasising more convenience and better compliance. Two GPs could not confirm the influence of dosage-forms. Patients' wishes, such as earlier success with prescription or as OTC-product, were generally confirmed to influence the choice for the same successful chemical entity. Only one GP denied this influence (table 6.3.a). Three GPs confirmed and four GPs denied that costs affected the choice between chemical entities in the same ATC-category. Some 
of the GPs who denied this influence built their opinion on the sheer absence of information on costs even on the computer, while prescribing, but recognised them as a part of the choice for their own "evoked set" of drugs within an ATC-category. In the A-group the GPs and the pharmacists considered the variety and the usefulness of different dosage-forms in the PTAMs (table 6.3.b). As such it was recognised as an item with influence during prescribing. The GPs in the A-group had the feeling that patients' wishes were easily coped with because they always could reproduce the discussions in the PTAM. Furthermore, the pharmacists were readily involved in the discussion if at any time a patient could not be convinced. A fitting alternative was always easily found. Costs aspects were part of the formulary agreements but only had direct influence when two chemical entities ended up equal after ample pharmaco-therapeutic discussion. The cheapest drug was then chosen. Sometimes even a complete category of drugs was excluded from the formulary. such as oral antimycotics now and cholesterol-inhibitors in an earlier period.

- Presents/attentions from pharmaceutical companies. Five out of seven GPs of the R-group denied that presents in any form by medical representatives affected their prescribing habits (table 6.3.a). Two GPs confirmed when asked for, that they had received gifts from pharmaceutical industries in return for prescription-trials with new drugs.

In the A-group the GPs stated that industry-involvement in the discussion about formulary-drugs as performed in their PTAM, is out of the question (table 6.3.b). Some of the GPs said to be suspicious of information by pharmaceutical companies, when they compare this information with the strict objectivity they had become used to in the PTAMs. If such objectivity could be guaranteed pharmaceutical companies were invited to give presentations in PTAMs, however.

'Bottlenecks' (table 6.1.e). During the interviews a number of possibly interesting items of different nature turned up as shortly are reported here:

In the R-group the following 'bottlenecks' were mentioned:

- the choice for an ATC-group is easier made than the choice between chemical entities within the ATC-group because of lack of appropriate information;

- medical representatives tend to give "coloured information' and sometimes cause a feeling of uncertainty with their 'me-too-preparations' and with drugs that were introduced with much palaver but were afterwards silently withdrawn from the market;

- "I sometimes take the responsibility for repeat-prescriptions of chemical entities which for some reason or other I still don't like";

- "I sometimes forget the contra-indication of a bad renal function when prescribing NSAIDs"; 
- where the effectiveness of NSAIDs is easily observed, anti-hypertensive medication is more difficult to assess; the absence of side effects was sometimes taken as a guideline for selection;

- ATC-groups with many new drugs are confusing and make you read more about them;

- much literature comes from industry-sources and is also read by consultants and its validity is then confirmed based on this not always independent literature;

- there is a need for better updating of computerised NHG-guidelines which includes the visualisation of costs during the prescription procedure;

In the A-group the following "bottlenecks" were mentioned:

- discussions on ATC-categories with many new drugs and confusing NHGguidelines often require (too) much time in repeated PTAM discussions;

- "nabumeton was a rational choice, but the results are somewhat disappointing as can be seen in our prescription patterns";

- "when we started our strict prescription policy, some problems arose with the hospital consultants about our refusal of repeat-prescriptions during their treatment; in the course of time, however, those problems are gone";

- "at the start it was often difficult to remember new first choices of drugs, especially when the PTAM and the first diagnosis were far apart in time; the computerised formulary has overcome these difficulties".

Answers to the additional questions for group A (table 6.1.f). All GPs of the A-group expressed great satisfaction with their PTAMs. The atmosphere was described as inspiring, safe, open, pleasant and social. They said to feel free to choose and maintain the best prescription policy. They stated that the expertise of the pharmacists and their own experience made this possible. The electronic formulary was mentioned as a product of all members of the PTAM and so none had the feeling that their hands were tied by regulations.

Their experiences from elsewhere were limited. The younger GPs had sometimes fulfilled their time a a trainee in other teaching practices and some had experience with temporary replacements in other practices. They were faced with both positive and negative attitudes towards their home situation.

The negative feelings of colleagues and pharmacists from other PTAMs towards the PTAM of the A-group were said to be sceptical and suspicious. Wrong ideas of doctors about pharmacists, wrong ideas of pharmacists about doctors, the fear that guidelines might be imposed top-down and then weigh down on you, were mentioned as possible reasons. The positive comments were curiosity, highly interested and jealous about the good cooperation in this close group. The opinion of the GPs about this judgement was that "some pharmacists do not deserve the credit for their PTAM, but because of prejudices sometimes pharmacists do not 
even get the chance to prove their quality".

Comparison with procedures in other PTAM-groups made all four individual GPs express as their opinion that without prejudices about one another and with sound ideas, agreements about the constitution and feed back maintenance of a formulary is possible in the majority of PTAM-groups.

\section{Discussion}

In order to evaluate the prescribing behaviour of general practitioners a number of different procedures and strategies can be considered. Registration of diseases and treatment with drugs provides information on prescription behaviour. Medication prescribed by GPs can be compared to guidelines for optimal treatment composed by experts and accepted and published by medical scientific societies. Deviations from the guidelines can be discussed and medical education can be directed at improvement of prescription behaviour. However, many prescribing physicians have a reticent attitude towards this type of intervention which they experience as unrequested interference with their own professional responsibility $(64,122)$. Assuming that drugs are prescribed according to a certain strategy (36) it seems to be important to gather information on the underlying considerations of the prescribing GPs. Once the strategy of prescription can be explained or at least elucidated, interventions might be more successful (37). In agreement with other investigators $(17,38)$ we therefore chose to evaluate the GP's prescription behaviour by investigating their knowledge and expectations as well as their considerations for the choice of the present therapy by individual interviews. We realised that this approach had some limitations due to differences between $R$ group and A-group practices, e.g. smaller numbers of patients in the practices in the A-group than in the R-group which might promote the opportunity for increased attention of the GPs in the A-group for individual patients. The patients' populations also showed some differences such as a greater proportion of elderly patients in the R-group practices. General limitations of our comparison method were the absence of diagnostic considerations in this study of aspects of drug therapy. However, this is in agreement with the supposition on which the NHGguidelines for therapy are based, i.e. that all doctors make the right diagnoses to the same extent.

Notwithstanding these limitations still the results of this study may lead to valuable general conclusions. We have reasons to suppose that 'unbound prescription' policy as we found in the R-group is common practice in the majority of PATMgroups in the Netherlands. The 'formulary-bound prescription' as practised in the A-group forms is at this moment only found in a small minority. In the near future, however, the official role of community pharmacists in the Netherlands and the 
legally implied influence of the health insurance companies, will bring about obligatory changes $(139,140,141)$ of which restriction of the freedom of prescription is mentioned to be involved.

All GPs appeared to be highly interested in retrospective investigation of their prescription behaviour. In the personal interviews they agreed that this might have a feed-back effect on future prescriptions as has been reported in studies on problem oriented education $(20,106)$.

The R-group. The GPs in the R-group generally overestimated their awareness of prescribing. This is in good accordance with a study about self-estimated performance and actual compliance of physicians with locally peer-defined quality evaluation criteria (131). It could hardly be expected that for each prescription a deliberate selection was made from the drugs available in the ATC-category concerned. This does not exclude, however, that attention is always paid to possible harm or damage to the individual patients to whom the drugs were administered. Nevertheless, a routine attitude could lead to irrational prescription, a habit which is difficult to cure and must be prevented by proper education (65). During the interviews many possible items were mentioned of which a number were only recognised as such after discussion. Obvious influences were bad experiences with some drugs such as lack of effect of treatment with sometimes complaints of patients. These were more prominent where the subjective experience of either doctor or patient played a significant role, e.g. gastric complaints during treatment with NSAIDs or unwanted (somatic) side effects of anti-depressive drugs. The influence of promotional activities by the pharmaceutical industry was another item. These included advertisements in professional literature, direct mail, provision of facilities and visits by medical representatives. Some trial and error procedures were registered leading to short term selection of new drugs but not to consistent changes in prescription. Finally changes in prescription were often induced by observed unwanted side effects and/or patients' complaints. In these cases the risk of trial and error policy can not be denied but could be diminished by proper education in drug therapy (13).

'Trial and error' on own initiative or stimulated by pharmaceutical companies were mentioned as a main reason for short term changes in prescription patterns. Some successful trials were confirmed by experienced effectiveness e.g. by satisfied patients, experienced safety, prescriptions from hospital specialists "NHGguidelines, professional literature and/or PTAM-discussions. The drugs from these trials might become a stable part of the 'evoked set' of the GP and from then on be routinely prescribed. Such policy is in accordance with other studies and is called the accumulation model (4). Lack of experienced effectiveness, side effects and/or accidents were said to lead to intentionally decreasing the number of 
prescriptions for the chemical entity in question. This is called the challenge model (4). It is surprising that the re-introduction of a known chemical entity which a GP had bad experiences with, could as a new brand mislead the same GP to take it in a trial it again. This was mentioned for e.g. piroxicam vs. piroxicam- $\beta-$ cyclodextrine-complex. Sometimes unconsciously recognised influences on e.g. safety, effectiveness and side effects were overruled by curiosity. At first the GPs hardly recognised that this led to persistently changing preferences for certain drugs which, however, could be demonstrated by the collected data from each practice. On closer inspection it was agreed that the reported changes often caused widening of the prescription spectrum, i.e. the prescription of more chemical entities from the relevant ATC-categories. This was especially so if a clear diagnosis was not easily made. An example was the treatment of patients who suffered from mental depression. From the vast number of different drugs in the ATC-category of anti-depressive agents, an increasingly varying number was prescribed in the course of time. Although exclusion of evidently inferior medication alternatives has been reported to lead to an increase of prescriptions for the better drugs (72), a decrease of prescriptions for drugs of supposed equal merit could not be observed. This behaviour was confirmed by other investigators (41) and improvement of treatment was not found (54). These observations emphasise the need for appropriate education in the field of antidepressive pharmaco-therapy. Surprisingly influence on prescription by marketing activities of the pharmaceutical industry was generally denied. Considering the huge efforts of the industry in informing, visiting and providing facilities to the profession, it might be supposed that prescription behaviour were influenced by those activities. This, however, was not only denied by the GPs participating in our investigation but was also confirmed in other studies (5). Although all GPs more or less frequently were visited by medical representatives, they did not recognise influence on their prescription behaviour. Nevertheless it was admitted that some trial and error procedures were caused by just these visits and the information from industrial sources. Participation in trials with new drugs was explicitly reported by three physicians in this group. Actually it seems improbable that these activities had no influence at all.

Another item was the influence on selection of drugs by therapy guidelines edited by professional bodies, which was reported to be only marginal. Similar reactions have been reported by others $(16,123)$. The indicated reasons for this lack of compliance were diverse. Medical reasons such as way of administration of the drugs or allergic reactions were recognised but also other reasons such as duration of treatment or patient's preference. Nonetheless in some ATC-categories a significant compliance to these guidelines was abserved. It may be questioned 
whether the promotion of guidelines is insufficiently stimulating and how this could be improved. It has been reported that compliance to guidelines increases if the latter are composed in cooperation with the users, i.e. the regional GPs (131). Considering prescriptions from hospital consultants, the GPs estimated this influence rather low. Although sometimes for patients leaving the hospital, specialist prescriptions were continued, this was no reason for GPs to change their own prescription behaviour in general. This statement was evidently supported by the observed diversity in GPs' prescription patterns which might be less if specialists from the local hospital would set the trend. An equally small significance was attributed to incidental discussions on therapy with colleagues in general practice. It was also mentioned that some drugs although not being the GPs first choice over the whole period still kept being prescribed in order to maintain a stable prescription pattern.

'Stability in prescribing' came up as an item during the interviews. We did not quantify the difference between stable and changing patterns. We tried to do so earlier in Chapters IV and V by determining the coefficients of variation. As we stated there, the coefficient of variation does not point clearly at good or bad changes viz. stability, without simultaneous study of the graphical change patterns. During the interviews there was never a difference of opinion to designate patterns as changing or stable. This might also be the case during PTAM. Nevertheless, when differences become smaller in free prescribing PTAM-groups, because formulary agreements are better followed, the need for a more precise instrument for the assessment of stability vs. change might arise.

A number of problems have been reported of which some were less expected. It was mentioned that choosing the most appropriate ATC-category was easier than the selection of the drug of choice within that category. The need was mentioned for development of strong pharmaco-therapeutic audit conferences where new drugs could be objectively discussed and their effects as abtained from medicalscientific studies be evaluated.

In proceeding the prescription even when it is computerised, some facts might have eluded the prescriber's actual attention. Nevertheless, these items could be important: contra-indications, pharmaco-kinetic properties, evidence from literature and professional education, pharmacist's advises, costs. This phenomenon was also described elsewhere for other items and risks (21). The authors judged that the risk assessment was too psychologically complex a task to be performed intuitively and that decision aids and clear protocols are needed. Still other authors suggested that a sequence of events may lead to changes (56).

The GPs in the R-group mentioned more influences for changing prescription behaviour than reasons for stability. This might partly explain the wide spectrum 
of prescribed different chemical entities and the high variety in prescriptions as found in the R-group (see also chapters $V$ and V).

The A-group. Interviewing the GPs from the A-group revealed that different objective sources such as professional literature, NHG-guidelines, professional education, information by pharmacists and PTAM discussions were positively appreciated. These GPs appeared to be more open to pharmaco-therapeutic knowledge from external sources than their colleagues in the R-group. Furthermore, their good experience with what they already learned from these sources convinced them of the positive value of active external information. Professional education and pharmaco-therapeutic expertise were maintained by reading information from the government and a limited number of professional journals. Participation in medical scientific courses and conferences was generally thought to be useful and even necessary but could seldom be realised due to the always heavy work load in general practice. However, substantial information was often primarily obtained by attending pharmaco-therapeutic audit conferences where contacts with leading pharmacists induced discussion and increase of knowledge. Much emphasis was also layed on one's own experience in general practice. This was also reflected in their self-assured attitude towards wishes of their patients, knowing that pharmacists were always ready to give an advise.

GPs' perceptions of the usefulness of drug therapy recommendations made by hospital pharmacists was also studied by other authors (30, 31). A majority of the physicians believed that the recommendations had a positive effect on patients' clinical status (31). Moreover, it appeared, that general practitioners working in close cooperation with pharmacists develop a collaborative approach to health care. We observed that the changes which were registered in the prescription patterns of the GPs of the A-group follow the continuity model, i.e. changing against a background of willingness to change (4).

After completion of our study a number of reports on the functional effects of PTAMs appeared containing interesting information (135). We summarised some relevant data (table 6.5). From these data it can be concluded that in the A-district the degree of structured cooperation was more developed than in the R-district, which is in line with our observations on the corresponding regional groups. Cooperation between GPs and pharmacists for the organisation of PTAMs is much better in the A-district and the same is true for the objectives aiming at improved prescription behaviour such as the willingness to make agreements on a common formulary, the attitude towards the use of a computerised formulary and the use of prescription data to obtain insight in one's own absolute and comparative prescribing behaviour. The developments in these districts support the point of view that improved prescription behaviour can be achieved by good cooperation 
between physicians and pharmacists, i.e. by optimal functioning of obligatory pharmaco-therapeutic audit meetings.

\section{Conclusions}

For valid conclusions from this retrospective evaluation a number of data have to be considered (table 6.4). Although the numbers of GPs in the A-group and in the R-group were equal, the numbers of prescriptions per 100 patients were significantly smaller in the A-group. This was also true for the diversity of prescribed drugs. Striking differences were also registered during the retrospective interviews on prescription policy. The number of (subconscious) influences on prescriptions in the R-group evidently exceeded that number in the A-group, where many influences had been prevented by the PTAM agreements and the resulting common formulary. No trial and error was allowed in the A-group, only deliberately changing patterns. In the R-group trial and error and increased prescription of more different drugs was recognised only by external influences. It might be concluded that the physicians in the A-group seemed to be more aware of their prescription behaviour than the physicians in the R-group. Although less prescribing does not always point at a better quality of prescription behaviour, nevertheless, we qualify the prudent and restrictive attitude towards prescribing by the GPs in the A-group as 'good prescription behaviour' which is emphasized by the smaller number of prescriptions (table 5.11).

Summarising the obtained information it can be concluded that prescription of drugs in general practice is still liable for improvement. In the first place the prescriber's awareness of the effects of his selection of a specified chemical entity must be increased. This can be realised by providing appropriate information on pharmacotherapy in specified cases of pathology. The stimulation of the use of guidelines for drugs prescription is an option. However, these guidelines should be clear and unambiguously developed in close cooperation with the GPs who are supposed to use them as a formulary $(123,131)$. Guidelines should be presented in a convincing style. This means that adequate and updated information on the 'state of the art' is indispensable. Moreover, in the obligatory schedules for continued education of GPs, pharmacotherapy should be treated with ample emphasis. Developments in the field must be brought to the attention of the GPs both structured and on a regular basis. This can be performed and in many places already is common practice through obligatory pharmaco-therapeutic audit meetings. Where practised, these PTAMs appeared to be potentially useful but often were not scheduled frequently enough. Discussions of physicians and pharmacists with representatives of the pharmaceutical industry should be directed at improvement of the necessary cooperation of the latter with the profession. The 
efficacy of the considerable efforts and costs of the industry to inform the prescribers is to a large extent denied by the latter which can be regretted. Improved information could perhaps be obtained through active interference by local pharmacists.

References: cf. general reference list (ch. II). 
table 6.1. Guideline for retrospective interviews with general practitioners on prescription of interchangeable drugs in specified ATC-categories.

a) Can you remember your own prescription-pattern (aware/unaware) as described here?

yes/no; comment.

b) Can you remember how the variation as shown here, has been achieved? drug 1, 2, 3 etc.

c) Can you remember how the stability as shown here, has been achieved? drug 1, 2, 3 etc.

d) Interview following the considerations in the article of Denig (17) as far as the topics possibly influence the stability or the variation of the prescription pattern; explain every item and ask whereupon these considerations are based:

\begin{tabular}{|l|l|l|}
\hline \multicolumn{1}{|c|}{ aspect: } & drugs & considerations \\
\hline effectiveness & & \\
\hline safety & & \\
\hline routine & & \\
\hline own experiences & & \\
\hline information by industry consultants & & \\
\hline colleagues' experiences & & \\
\hline expectations and appreciation afterwards & & \\
\hline side effects; contra-indications & & \\
\hline information by pharmacist & & \\
\hline information in pharmacotherapy audit group & & \\
\hline national guidelines (NHG) & & \\
\hline post academic professional training & & \\
\hline prescriptions initialised by hospital consultants & & \\
\hline convenience of dosage or administration & & \\
\hline wishes of the patient & & \\
\hline costs & & \\
\hline $\begin{array}{l}\text { have "presents" of the industry been of any } \\
\text { influence }\end{array}$ & & \\
\hline
\end{tabular}


e) Name the bottlenecks mentioned in the article of Koomen $(36,37)$ and discuss them one by one with possible solutions: pharmaco-therapeutic skills (especially in the therapeutic groups in this study), accessibility and informative value of drug information of different sources: electronic prescription systems, formularies, auditgroup agreements, effect of subjective influences on drug-choices and advises.

\begin{tabular}{|c|c|}
\hline \multirow{2}{*}{$\begin{array}{l}\text { pharmacotherapeutical skills, knowledge and experi- } \\
\text { ence about NSAIDs }\end{array}$} & considerations \\
\hline & \\
\hline 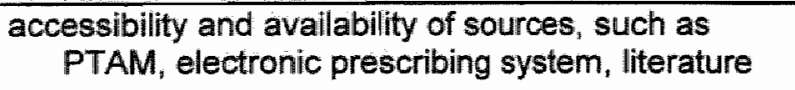 & \\
\hline $\begin{array}{l}\text { practical informative value of sources such as PTAM, } \\
\text { electronic prescribing system, literature, etc. }\end{array}$ & \\
\hline $\begin{array}{l}\text { effects of subjective information on drug-choice and } \\
\text { drug-information. }\end{array}$ & \\
\hline general remarks and observations: & \\
\hline
\end{tabular}

\section{f) additional questions for group A:}

\begin{tabular}{|l|l|}
\hline how do you like this way of practical behaviour & \\
\hline do you have practical experience elsewhere & \\
\hline $\begin{array}{c}\text { what do you know about the judgement of col- } \\
\text { leagues in other PTAM-groups and what is your } \\
\text { opinion about their judgement }\end{array}$ & \\
\hline $\begin{array}{l}\text { how do you compare their prescription policy with } \\
\text { your own prescription behaviour }\end{array}$ & \\
\hline
\end{tabular}


table 6.2. Items spontaneously mentioned by numbers of GPs in the R-group to have influence on variability or stability in prescribing

\begin{tabular}{|c|c|c|}
\hline $\begin{array}{l}\text { nr of } \\
\text { GPs }\end{array}$ & reasons for changing & reasons for stability \\
\hline \multicolumn{3}{|c|}{ R-group } \\
\hline 7 & own trial and error & \\
\hline 5 & trial on request of industry & \\
\hline 3 & $\begin{array}{l}\text { ageing of patients, presents of industry, } \\
\text { depression is more often diagnosed } \\
\text { and medically treated now }\end{array}$ & $\begin{array}{l}\text { own conservative character, } \\
\text { experienced safety of used } \\
\text { drugs }\end{array}$ \\
\hline 2 & $\begin{array}{l}\text { longer waiting-lists create increasing } \\
\text { prescription numbers }\end{array}$ & $\begin{array}{l}\text { own first choices confirmed by } \\
\text { NHG, choices confirmed by } \\
\text { satisfied patients }\end{array}$ \\
\hline 1 & $\begin{array}{l}\text { earlier discharging from hospital makes } \\
\text { increasing prescription numbers, } \\
\text { ineffectiveness, side effects }\end{array}$ & $\begin{array}{l}\text { specialists" prescriptions, own first } \\
\text { choices confirmed by PTAM, } \\
\text { effectiveness }\end{array}$ \\
\hline \multicolumn{3}{|c|}{ A-group } \\
\hline 7 & $\begin{array}{l}\text { PTAM and NHG-guidelines, including } \\
\text { safety, effectiveness, side effects, } \\
\text { pharmacokinetic properties, own } \\
\text { experience, convenience of dosage } \\
\text { forms and costs, specialists' pre- } \\
\text { scriptions }\end{array}$ & $\begin{array}{l}\text { PTAM and NHG-guidelines, in- } \\
\text { cluding safety, effectiveness, } \\
\text { side effects, pharmacokinetic } \\
\text { properties, own experience, } \\
\text { convenience of dosage forms } \\
\text { and costs, patients' satisfac- } \\
\text { tion } \\
\end{array}$ \\
\hline
\end{tabular}


table 6.3.a. Items that do and do not influence prescribing behaviour; answers classified in order of agreement in interviews with the GPs in the R-group.

\begin{tabular}{|c|c|c|}
\hline $\begin{array}{l}\text { nr of } \\
\text { GPs }\end{array}$ & items with recognised influence & $\begin{array}{l}\text { items without recognised } \\
\text { influence }\end{array}$ \\
\hline 7 & effectiveness, safety, side effects, routine & \\
\hline 6 & $\begin{array}{l}\text { own experience, medical representative, } \\
\text { repeat prescriptions, dosage-forms: vari- } \\
\text { ety, ease, convenience, compliance, } \\
\text { combination-preparations. }\end{array}$ & \\
\hline 5 & $\begin{array}{l}\text { earlier success with patient on prescription } \\
\text { or as an OTC-product }\end{array}$ & $\begin{array}{l}\text { colleagues' experiences, } \\
\text { presents of industry }\end{array}$ \\
\hline 4 & $\begin{array}{l}\text { pharmacist in (PTAM), NHG-guidelines, } \\
\text { contra-indications }\end{array}$ & $\begin{array}{l}\text { professional education, costs, } \\
\text { NHG-guidelines, pharma- } \\
\text { cists }\end{array}$ \\
\hline 3 & $\begin{array}{l}\text { professional literature, costs, } \\
\text { pharmacokinetic properties }\end{array}$ & \\
\hline 2 & $\begin{array}{l}\text { wishes of the patient, presents of industry, } \\
\text { professional education }\end{array}$ & $\begin{array}{c}\text { PTAM(FTO), ease of dosage, } \\
\text { medical representative }\end{array}$ \\
\hline 1 & & $\begin{array}{l}\text { repeat prescriptions, wishes of } \\
\text { the patient }\end{array}$ \\
\hline
\end{tabular}

influences not recognised when asked for, but turned out elsewhere in the interview to be of influence

influences confirmed when asked for, but turned out elsewhere in the interview to be neglected patients' wishes, NHG-guidelines, literature, own opinion, industry presents, pharmaco-therapeutic literature

disappointing side effects (coughing) with fosinopril the disaduantage of fosinopril that it is incompatible with all diuretics, experience with dangerous side effects of a chemical entity (piroxam), yet prescribed in another newly introduced form 
table 6.3.b. Items that do and do not influence prescribing behaviour; answers classified in order of agreement in interviews with the GPs in the A-group.

\begin{tabular}{|c|c|c|}
\hline $\begin{array}{c}\text { nr of } \\
\text { GPs }\end{array}$ & items with recognised influence & $\begin{array}{c}\text { items without recognised } \\
\text { influence }\end{array}$ \\
\hline 7 & $\begin{array}{c}\text { effectiveness, safety, routine, own experience, } \\
\text { colleagues experiences, side effects, contra- } \\
\text { indications, }\end{array}$ & $\begin{array}{c}\text { Information and presents } \\
\text { from medical repre- } \\
\text { sentatives, }\end{array}$ \\
& $\begin{array}{c}\text { information by pharmacist, information in PTAM, } \\
\text { NHG-guidelines, prescriptions initialised by } \\
\text { hospital consultants, } \\
\text { convenience of dosage-forms, wishes of the } \\
\text { ation afterwards, } \\
\text { patients, costs. }\end{array}$ & literature \\
\hline
\end{tabular}

\begin{tabular}{|c|l|}
\hline $\begin{array}{c}\text { influences not recognised when asked for, but turned } \\
\text { out elsewhere in the interview to be of influence }\end{array}$ & none \\
\hline $\begin{array}{c}\text { influences confirmed when asked for, but turned out } \\
\text { elsewhere in the interview to be neglected }\end{array}$ & none \\
\hline
\end{tabular}


table 6.4 Comparative data concerning prescription behaviour during three and a half years in the Reference-group and in the Audit-group

(all prescriptions of drugs in six ATC-categories were included)

\begin{tabular}{|l|l|l|}
\hline & Audit-group & Reference-group \\
\hline nr. of GPs & 7 & 7 \\
\hline nr. registered patients & 13,899 & 19,087 \\
\hline regulated prescription & yes: common formulary & no: 'unbound' prescription \\
\hline nr. prescr.100 patients & 163 & 215 \\
\hline $\begin{array}{l}\text { variety in prescription: } \\
\text { total nr. of different drugs } \\
\text { prescribed in six ATC-cat. }\end{array}$ & $\begin{array}{l}42 \text { drugs selected out of } \\
\text { in total 77 drugs listed in } \\
\text { six ATC-categories }\end{array}$ & $\begin{array}{l}67 \text { drugs selected out of } \\
\text { in total 77 drugs listed in } \\
\text { six ATC-categories }\end{array}$ \\
\hline compliance & $\begin{array}{l}72 \% \text { compliance with } \\
\text { NHG-guidelines; } \\
79 \% \text { compliance with } \\
\text { A-group formulary }\end{array}$ & $\begin{array}{l}\text { f3\% compliance with } \\
\text { NHG-guidelines }\end{array}$ \\
\hline $\begin{array}{l}\text { nr. of items mentioned to } \\
\text { influence prescription } \\
\text { behaviour }\end{array}$ & only PTAM agreements & $\begin{array}{l}>13 \text { different items; } \\
\text { some negative influences: } \\
\text { bad experiences, } \\
\text { lack of therapeutic effect, } \\
\text { side effects, } \\
\text { patients complaints, } \\
\text { industrial promotion, } \\
\text { trial \& error, } \\
\text { attentions from industry, } \\
\text { confusing information, } \\
\text { no mutual consultations. }\end{array}$ \\
\hline
\end{tabular}


table 6.5 Function of pharmaco-therapeutic audit meetings in two districts

\begin{tabular}{|c|c|c|}
\hline & $\operatorname{district} A$ & district $R$ \\
\hline Number of participating PTA-groups & 34 & 58 \\
\hline - mean number of GPs per group & 9.0 & 8.9 \\
\hline - mean number of pharmacists per group & 2.9 & 2.5 \\
\hline $\begin{array}{l}\text { Organisation of PTAM in cooperation be- } \\
\text { tween GPs and pharmacists } \\
*\end{array}$ & $93.5 \%$ & $70.7 \%$ \\
\hline Objectives and aims clearly defined: & $58.1 \%$ & $48.3 \%$ \\
\hline - common formulary & $29.0 \%$ & $20.7 \%$ \\
\hline - reduction of number of prescriptions & $30.0 \%$ & $48.3 \%$ \\
\hline $\begin{array}{l}\text { - reduction of simultaneous prescription } \\
\text { of different drugs }\end{array}$ & $13.3 \%$ & $6.9 \%$ \\
\hline Use of electronic formulary in the district: & & \\
\hline$-\%$ of all GPs & $3.2 \%$ & $1.8 \%$ \\
\hline$-<50 \%$ of PTA-groups & $12.9 \%$ & $25.0 \%$ \\
\hline $\begin{array}{l}\text { Positive attitude towards use of electronic } \\
\text { formulary } \\
* *\end{array}$ & $48.0 \%$ & $39.6 \%$ \\
\hline $\begin{array}{l}\text { Numerical information on prescription data } \\
\text { used: }\end{array}$ & $76.7 \%$ & $60.7 \%$ \\
\hline $\begin{array}{l}\text { - purpose: information on own prescrip- } \\
\text { tion policy }\end{array}$ & $70.0 \%$ & $55.2 \%$ \\
\hline - purpose: comparison with colleagues & $60.0 \%$ & $41.4 \%$ \\
\hline
\end{tabular}

* percentage of PTA-groups

* percentage of GPs 
CHAPTER VII

INFLUENCE OF A PRESCRIPTION FORMULARY ON COST OF MEDICATION 
Introduction. The ever increasing expenditures on pharmacotherapy in the countries of the Western world are a cause of continuous concern for all parties involved. Not only the patients and the doctors but also medical societies, the pharmaceutical industries and last but not least the national governments are aware that perhaps the greatest health care challenge of the next decade is making the best use of limited available resources to attain the highest quality for the lowest cost (136). In the Netherlands, population 16 million, drug costs make up the greater part $(79 \%)$ of the total expenditure on pharmaceutical aid. The costs increased from $f 3369 / € 1530$ (millions) in 1990 to an estimated amount of $f 6335 / € 2880$ (millions) in 1999, a mean annual increase of almost $9 \%$ (132). Several efforts to reduce or at least stabilise the cost and consumption of drugs have been little successful and even in 1998 the expenditures on pharmaceutical aid by community pharmacies increased well over $11 \%$ as compared to the year before. It appeared that almost two thirds of the increment of costs could be attributed to three categories of drugs, i.e. cardiovascular drugs $26 \%$, drugs concerning the central nervous system $19 \%$ and drugs concerning the gastrointestinal tract $18 \%$. A similar increase had not been observed in the preceding ten years. In the period 1994-1998 the government managed to limit the annual growth of the expenditures on drugs to an average of $5.25 \%$. This was realised by means of forced price measures and by thinning out the statutorily insured drug package. Without these measures the growth would have ended up at the structural level of $10-12 \%$ per year. The possibilities to economise extra costs in the same way gradually run out. For the cost control on the longer term, the Ministry of Health aims particularly at the cooperation between prescribing physicians, pharmacists and health insurance companies. Two main factors could be held responsible for the increasing costs. First a change in consumption patterns to newly available often more expensive drugs was observed. Another not less important aspect is the ageing of the Dutch population. It is expected that the number of senior citizens in the Netherlands will have increased by $16 \%$ in the next ten years. Moreover, the consumption of drugs by Dutch people of 65 years and older is 2.9 times the average amount of drugs consumed in the entire population. The larger consumption of drugs by elderly persons leads to proportional higher expenditures on drugs (132).

In an earlier study (chapters $V$ and $V I$ ) we found that the prescription behaviour of general practitioners was influenced by the use of a formulary restricting the number of drugs available for prescription. We therefore decided to investigate differences in expenditures on pharmacotherapy between a group of GPs prescribing drugs in six ATC-categories from a limited formulary (Audit-group; 
A-group) and a reference group (R-group) prescribing from the complete ATClist. The following items were compared:

- number of prescriptions per 100 patients per ATC-category and overall

- variety between number of treatments by GPs in each group

- drug expenditures per 100 patients per ATC-category and overall

- influence of different age categories in A-group and R-group practices

\section{Methods}

Practice characteristics and prescription policy (table 7.1). The physicians in the A-group, seven GPs, agreed to prescribe along the guidelines of a common regional formulary containing a selection of 15 drugs from six ATC-categories. Together they served a total number of $8,395 \mathrm{NHS}$-registered patients. In the R-group, seven GPs serving in total 10,358 NHS-registered patients, no agreements on prescription had been made and drugs were selected from the full ATC-list of 77 drugs (cf. chapter V). The relation between the proportion of elderly patients and drug consumption and expenditures was investigated (table 7.2). This was taken into consideration because from national data (132) it could be calculated the population of patients over 64 years of age apparently use $69 \%$ of total national drug consumption with $71 \%$ of national expenditures.

Categories of drugs. Data on prescription and costs of drugs in six ATC-categories in the A-group were compared with corresponding data from the Rgroup. Prescriptions for NSAIDs, ACE-inhibitors, anti-depressive drugs, Bblocking agents, Ca-entry blocking agents and inhibitors of cholesterol synthesis were studied. In the A-group a regional formulary had been composed by the GPs in cooperation with the local pharmacists (table 7.3).

Data collection. For statutorily insured patients, data on numbers of presciptions and treatments and related costs are registered by the regional health insurance company since about ten years. These data originate from the computerised monthly declarations of community pharmacists and were kindly put at our disposal for which permission of the GPs was obtained. The declarations contain precise data of all prescriptions about, among others, the identity of the prescriber and the drug, costs, use and prescribed quantity of medication. These data can be trusted to be accurate and complete. In the community pharmacy these data are twice controlled, i.e. by both the pharmacy assistent and the pharmacist. These data form the basis of the computerised surveillance system of interactions, contraindications, dosages and stock of medication. The computer system of the health insurance company has greatly improved over the years and it has been made more and more suitable for giving feedback on prescription. Regrettably, for technical/clerical reasons, comparable figures 
concerning expenditures in former periods were not available which prevented a longitudinal study on cost development in both regions.

Data processing. Numbers of prescriptions and treatments per 100 registered patients as well as costs were calculated per ATC-category and overall. Linear correlation coefficients were calculated to determine the relation between the numbers of prescriptions and the proportion of elderly patients ( $>65$ years of age) in A-group and R-group practices (table 7.2). Moreover, using available statistical data on national drug consumption and expenditures (table 7.4), age adjustment through indirect standardisation of obtained results to virtual populations with national age distributions was performed in order to eliminate the influence of different age distributions of patient populations on comparison between the A-group and the R-group.

\section{Results}

Practice characteristics and prescription policy. The number of NHS-insured patients in the A-group was exceeded by $23 \%$ in the R-group. Moreover, a higher proportion of elderly patients $(20.9 \%)$ was registered in the latter group as well as a slightly higher percentage of work incapacitated patients (table 7.1).

The GPs in the A-group selected to a large extent drugs from the A-formulary (15 drugs; compliance $79 \%$ ) but other drugs from the ATC-list were also prescribed. The overall selection varied from 31-42 different chemical entities between physicians. A larger variety was observed between GPs in the Rgroup, selecting 48-67 different drugs from the complete ATC-list (table 7.1).

Correlation coefficients have been calculated for the relation between the proportion of elderly patients and drug consumption (number of prescriptions) and expenditures in each practice and overall for the A-group and R-group. It appeared that low correlations were generally found in the R-group. In the $A$ group good correlations were found overall $(0.94)$ and for consumption of ACEinhibitors $(0.65)$, anti-depressants $(0.88), \beta$-blocking agents $(0.93)$ and cholesterol-inhibitors (0.90). Similar patterns were found for expenditures (table 7.2).

Differences in drug consumption and drug treatment (table 7.5). The number of drug therapy treatments in the R-group (269.1 treatments $/ 700$ pat.) exceeded the number of treatments in the A-group (140.9 treatmants $/ 700$ pat.) by $91 \%$. Drug consumption defined as number of prescriptions per 100 patients in the R-group ( $499.9 / 700$ pat. $=71.4 / 100$ pat.) exceeded drug consumption in the A-group ( $291.7 / 700$ pat. $=41.7 / 100$ pat.) by $71 \%$. We observed that the number of prescriptions per treatment in the $\mathbb{R}$-group was smaller than in the Agroup for ACE-inhibitors, anti-depressants, Ca-entry blocking agents and $\beta$ - 
blocking agents. Equal numbers of prescriptions per treatment were prescribed for treatment with NSAIDs and with cholesterol-synthesis inhibitors.

After adjustment for different age categories the number of prescriptions per 100 patients in the R-group was reduced to 59.9 and in the A-group to 39.8 which shows that drug consumption in the R-region still exceeded consumption in the A-region by $51 \%$ (table 7.6 ).

Differences in drug expenditures. Along with a smaller drug consumption also the drug expenditures in all ATC-categories were less in the A-group than in the R-group (table 7.7). Not only the cost/prescription but also the total costs/100 patients in all ATC-categories was smaller in the A-group than in the R-group in spite of the fact that in four categories the number of prescriptions per treatment (table 7.5) was larger in the A-group.

Conversion of age categories to virtual populations based on national means eliminated the direct influence on cost figures but drug expenditures in the Rregion still exceeded expenditures in the A-region even by $104 \%$ (table 7.8 ).

Influence of practice groups. In multiple linear regression analysis it was confirmed that the influence of practice group $(A=1 ; R=0)$ was highly significant and independent from practice size and age distribution (table 7.10).

\section{Discussion.}

The use of formularies listing a limited number of drugs of choice is now an often used approach for improvement of cost-effective drug therapy $(66,133$, 136). Formularies have been developed both by national medical organisations and by regional or local groups of GPs (155). The general idea behind this policy was that limiting the number of different chemical entities for prescription would increase the experience and expertise of the prescribers leading to improved pharmacotherapy. In agreement with this we found a smaller number of prescriptions per 100 patients in the A-group (table 7.5) where the participating GPs selected drugs from a limited formulary which had been composed and maintained by themselves in cooperation with the local pharmacists. The latter fact may well have contributed to a good compliance (table 7.1) with the formulary $(118,152,155)$. We also observed a reduced number of treatments per 100 patients suggesting a better awareness when prescribing as has been mentioned by other investigators as well $(119,120)$. More conscious treatment could also be deduced from the fact that the GPs in the A-group wrote out more prescriptions per treatment in four ATC-categories (table 7.5). They explained this by the fact that the quantity of drugs per prescription was often deliberately kept low for which medical reasons were given. Moreover, it was considered that patients' compliance with prescribed drug therapy decreases with time and 
this leads to a not unimportant quantity of drugs being discarded by the patients. At least eliminating this waste of drugs contributes to cost reduction. Actually a reluctant prescription behaviour appeared to be in line with reduced costs for pharmaco-therapy (table 7.7). Furthermore a good correlation of the number of prescriptions with the proportion of elderly patients was observed in the A-group (table 7.2) which is in line with national statistical data (132). Remarkably, although the proportion of elderly patients in the R-group exceeded the proportion in the A-group, correlations of prescription with the said proportions were generally low. This could suggest a certain lack of prescription discipline leading to easy prescription also for the lower age categories.

It must be mentioned that each physician followed his own line of treatment which explained the sometimes large ranges in observed numbers of prescriptions (table 7.5). However, it has also been argued that variations in prescription costs between physicians in comparable situations essentially reflect patients" demands and the doctor's capability to handle these (48).

Nevertheless, care must be taken to keep up with progress in medicine. Introduction of newer and often more expensive drugs should be possible if needed. Progress in pharmaceutical science provided possibilities for treatment of hitherto untreatable disorders. The positive outcomes of the newer drugs must be translated into cost benefits if formularies are to be intelligently controlled (134). Appropriate medical education focusses on this aspect of progress in medicine. Information on new drugs is often and sometimes insistently disseminated by pharmaceutical sales representatives. The influence of GPs' attitudes toward and use of such information on prescribing costs in ambulatory practice has been evaluated (86). A significant positive correlation has been found between GPs' cost of prescribing and perceived credibility, availability, applicability and use of information provided by pharmaceutical representatives (86). Frequency of use of industrial information may be associated with increased primary care physician prescribing costs related to introduction of newly developed and available drugs. Physicians in academic or hospital-based practice settings had significantly lower prescribing costs (86). On the other hand, a more conservative prescription policy could work against the interest of patients and economy as was demonstrated in a review on the pattern of prescribing medicine in the UK. In comparison to major European markets, the conservative nature of the British prescription medicine market was indicated by three items. British doctors prescribed fewer items per patient per year and appeared to be less likely to prescribe a product containing a new chemical entity. An increasing resistance to the use of newer medicines was observed over the past decade. Finally, British physicians relied on a progressively smaller num- 
ber of active substances for a greater proportion of their prescriptions. As a result of these trends the pharmaceutical industry in Britain is becoming more dependent on the sales of older products and on the occasional 'blockbuster' to finance its research. Declining uptake of new medicines, coupled with increasing pressure on doctors to prescribe cheaper generics instead of branded medicines, reduced the ability of pharmaceutical companies to fund their investment in research into as yet unconquered diseases. This trend could work against the interests of both patients and industry $(98,99,115)$. From the mentioned studies it could be shown that a too restrictive policy towards the pharmaceutical industry, although perhaps saving money, might work against the progress of health care. In order to prevent this the GPs in the A-group in our study organised compulsory monthly pharmacotherapeutic audit meeting of GPs and pharmacists where information from the pharmaceutical industry was discussed and commented (155). From time to time pharmaceutical representatives have been invited to participate in the discussions.

Comparing expenditures for pharmacotherapy between the A-group and the Rgroup we observed a considerable reduction of costs in the A-group where a prescription formulary was followed. Both costs per 100 patients and costs per prescription were lower (table 7.7). That costs per prescription were lower in the A-region might be partly due to a limited quantity of drugs per prescription and a larger number of prescriptions per treatment in four categories which reflects treatment policy. However, overall costs still remained lower than in the Rgroup. Another not unimportant fact was that the practices in the R-region contained a proportional higher number of elderly patients (table 7.1) and in general drug consumption by senior citizens is increased $(104,132)$. A correction for age distribution differences was made by indirect standardisation of both populations in the A-region and in the R-region to virtual populations based on overall national age distributions. After standardisation drug expenditures in the R-region still exceeded the A-region by $104 \%$ (table 7.8). Apparently the use of a regional formulary and the concomitant obligatory pharmacotherapeutic audit meetings influenced prescription behaviour to a large extent.

Cost containment measures which include prescribing from a formulary are now widely encouraged $(136,152)$. Prescribing analysis and cost trends data generated from pharmacists collecting dispensed GPs' prescriptions are a valuable tool $(89,106)$. Centralised data processing could be used to identify areas where prescribing an expensive formulation has led to a dramatic increase in costs. The same data could be used by GPs when preparing a common formulary $(133,155)$. Although composition of formularies for drug therapy primarily 
aims at improved pharmacotherapy, many GPs recognised the need for cost reduction wherever possible. They were aware that rapidly inflating health care costs limit patient care and that costs of prescribed drugs constitute a major component of this expenditure. Physicians' knowledge of drugs costs, however, was often inadequate and costs were not readily accessible. A need was felt for better physician education and information on costs should be included in the formularies (66). Moreover, cost considerations should be an essential item in the decision which drugs are to be listed in the formulary (136). It goes without. saying that the medical aspects of the formulary have priority over the economic aspects. Care must be taken not to contribute too much importance to cost factors as this might undermine the credibility of the formulary as a recommended guideline for pharmacotherapy (142).

Finally we compared the rate of organised cooperation between GPs and pharmacists in the districts where the A-group and the R-group physicians are working. The A-group with seven practising GPs and the R-group, also seven GPs, are situated each in its own district in the southern part of the Netherlands. In both districts pharmacotherapeutic audit groups are active although not to the same extent. Comparative data are given in table 7.8. Despite methodological limitations as pointed out earlier (chapter $V$ ) it can be concluded that the degree of audit organisation and the inherent interest for structured pharmacotherapy was more pronounced in the A-district. Nevertheless, even in the A-district only $29 \%$ of the PTA-groups aimed at composition a common formulary against even less (20.7\%) interest in the R-district. On the contrary, in the latter district reduction of the number of prescriptions attracted more attention whilst the need for comparison of prescription behaviour with colleagues was more pronounced in the A-district. Moreover, in our study it was confirmed that the influence of practice group was highly significant and independent from practice size and age distribution.

From our results we conclude that regional cooperation between GPs and pharmacists through regular pharmacotherapeutic audit meetings and the development and maintenance of a common formulary for drug prescription can be a valuable tool to improve drug therapy and to reduce drug expenditures in general practice.

References: cf. general reference list (ch. II). 
table 7.1. Combined data on practices and prescription policy of GPs in the Audit-group and in the Reference-group.

\begin{tabular}{|c|c|c|}
\hline & A-group & R-group \\
\hline $\mathrm{nr}, \mathrm{GPs}$ & 7 & 7 \\
\hline total nr. patients & 13,899 & 19,087 \\
\hline nr. NHS-registered patients * & $\begin{array}{l}8,395 \\
(60 \% \text { of total })\end{array}$ & $\begin{array}{l}10,358 \\
\text { (55\% of total) }\end{array}$ \\
\hline $\begin{array}{l}\text { patients' age ranges } \\
\text { - } \quad 0-19 y \\
\text { - } \quad 20-39 y \\
\text { - } \quad 40-64 \mathrm{y} \\
\text { - } \quad>65 \mathrm{y} \\
\text { work incapacitated patients }\end{array}$ & $\begin{array}{l}22.4 \% \\
32.1 \% \\
30.1 \% \\
15.4 \% \\
7.3 \% \\
\end{array}$ & $\begin{array}{r}15.8 \% \\
31.4 \% \\
31.9 \% \\
20.9 \% \\
8.2 \% \\
\end{array}$ \\
\hline prescribed drugs selected from & $\begin{array}{l}\text { formulary (priority) } \\
\text { and ATC-list }\end{array}$ & $\begin{array}{l}\text { compiete ATC-list; } \\
\text { no formulary }\end{array}$ \\
\hline $\mathrm{nr}$. different drugs available & formulary 15 drugs & 77 drugs \\
\hline nr. different drugs prescribed & $31-42 * *$ & $48-67 *$ \\
\hline mean compliance with formulary & $79 \%$ & - \\
\hline mean compliance with NHG-guidelines & $72 \%$ & $63 \%$ \\
\hline
\end{tabular}

* number of statutorily NHS-registered patients

* variety between GPs 


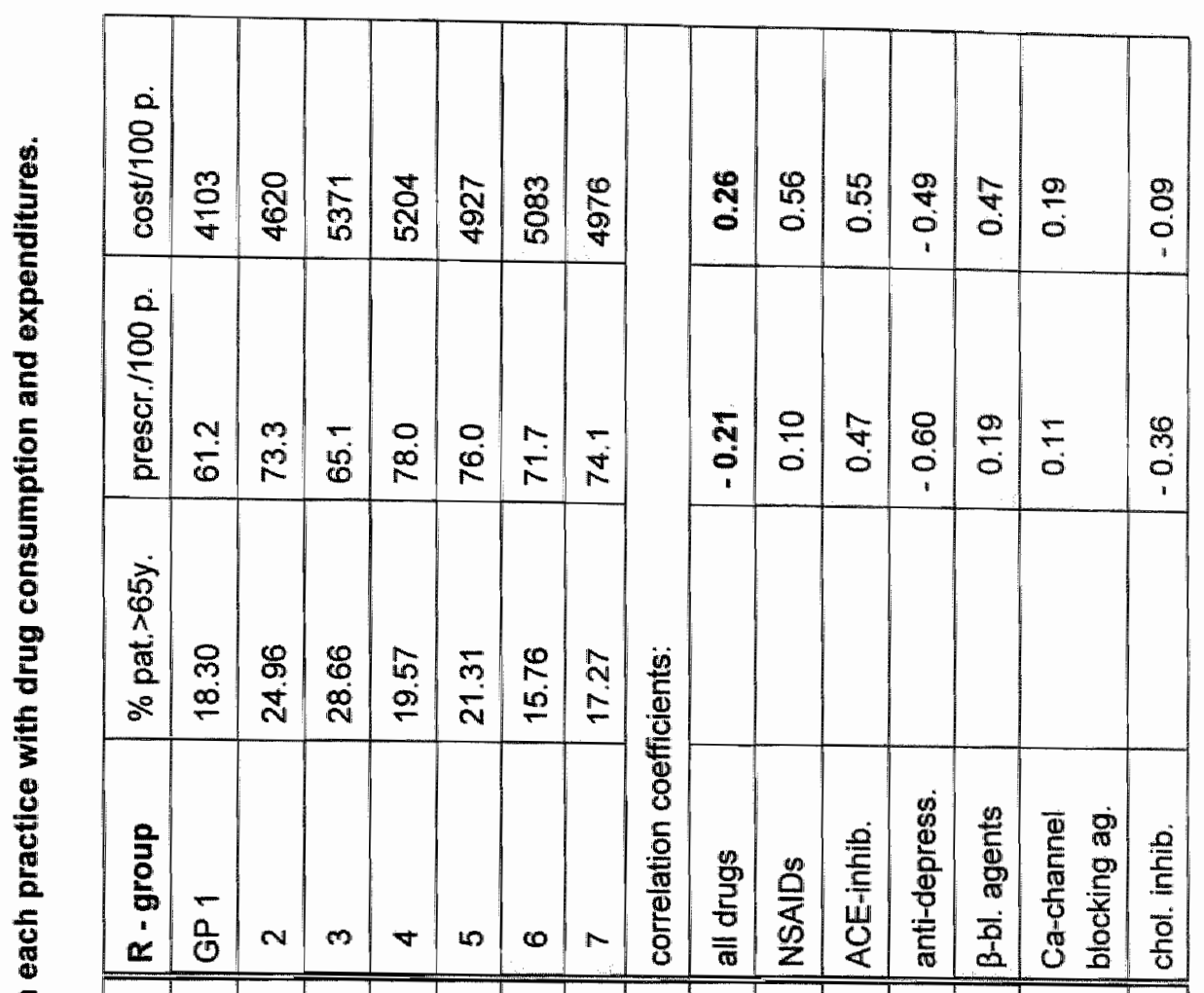

5

를

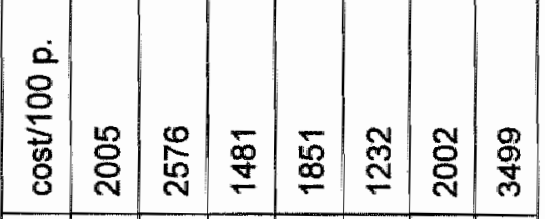

这

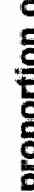

倦

$\frac{5}{\frac{10}{0}}$

$\vec{\infty}$

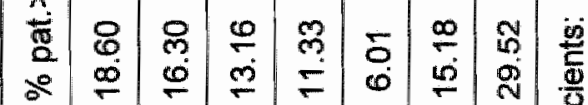

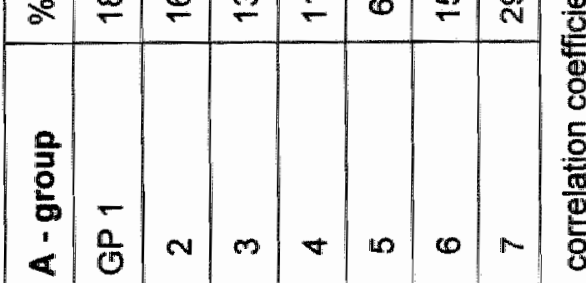


table 7.3. ATC-categories with indication of drugs listed in the A-formulary and in the NHG-guidelines.

\begin{tabular}{|c|c|c|c|c|c|}
\hline NSAIDs & $\begin{array}{l}\text { ACE- } \\
\text { inhibitors }\end{array}$ & $\begin{array}{l}\text { anti- } \\
\text { depressants }\end{array}$ & $\begin{array}{l}\text { beta-blocking } \\
\text { agents }\end{array}$ & $\begin{array}{l}\text { Ca-channel } \\
\text { block. agents }\end{array}$ & $\begin{array}{l}\text { chol. } \\
\text { inhibitors }\end{array}$ \\
\hline M01A & $\mathrm{COgA}$ & N06A & $\mathrm{COTA}$ & $\mathrm{COBC}$ & C10AA \\
\hline \multicolumn{6}{|l|}{ A-formulary } \\
\hline diclofenac & captopril & paroxetine & atenolol & nifedipine & simvastatin \\
\hline ibuprofen & enalapril & clomipramine & pindolol & amlodipine & pravastatin \\
\hline nabumetone & & moclobemide & & & fluvastatin \\
\hline \multicolumn{6}{|l|}{ NHG-guide- } \\
\hline diclofenac & captopril & amitriptyline & atenolol & nifedipine & simvastatin \\
\hline ibuprofen & enalapril & imipramine & metoprolol & nitrendipine & pravastatin \\
\hline naproxen & & fluvoxamine & & & \\
\hline \multicolumn{6}{|c|}{ complete ATC-list } \\
\hline aceclofenac & benazepril & amitriptyline & acebutolol & amlodipine & atorvastatin \\
\hline azapropazone & captopril & citalopram & alprenolol & fielodipine & cerivastatin \\
\hline diclof./misopr. & cilazapril & clomipramine & atenolal & irsadipine & fluvastatin \\
\hline diclofenac & enalapril & desipramine & betaxollol & lacidipine & pravastatin \\
\hline fenylbutazone & fosinopril & dosulepine & bisoprolol & lercanidipine & simvastatin \\
\hline flurbiprofen & lisinopril & doxepine & carvedilol & mibefradil & \\
\hline ibuprofen & perindopril & fluoxetine & celiprolol & nicardipine & \\
\hline indometacin & quinapril & fluvoxamine & labetalol & nifedipine & \\
\hline ketoprofen & ramipril & imipramine & metoprolal & nimodipine & \\
\hline meloxicam & trandolapril & maprotiline & nebivolal & nisoldipine & \\
\hline nabumetone & & mianserine & oxprenolol & nitrendipine & \\
\hline naproxen & & mirtazapine & pindolol & & \\
\hline piroxicam & & moclobemide & propanolol & & \\
\hline tenoxicam & & nefazodone & sotalol & & \\
\hline tiaprof.acid & & nortriptyline & tertatolol & & \\
\hline \multirow[t]{5}{*}{ tolfenamic acid } & & paroxetine & & & \\
\hline & & sertraline & & & \\
\hline & & trazodone & & & \\
\hline & & trimipramine & & & \\
\hline & & venlafaxine & & & \\
\hline & & & & & \\
\hline total nrs. 16 & 10 & 20 & 15 & 11 & \\
\hline
\end{tabular}

* withdrawn from the market on account of interactions 
table 7.4. Comparison of population and prescription data in A-region and R-region with overall national data.

Age categories in the A-region and in the R-region;

national age categories with drug consumption (number of prescriptions per year) and drug expenditure (guilders per year) per age group and mean values (1998).

\begin{tabular}{|c|c|c|c|c|c|c|}
\hline & A - region & R - region & \multicolumn{4}{|c|}{ national data * } \\
\hline age category & & & \multicolumn{2}{|c|}{ age category } & & \\
\hline $0-19 y$. & $22.4 \%$ & $15.8 \%$ & $0-19 y$. & $24.3 \%$ & 3.0 & 114 \\
\hline $20-39 y$ & $32.1 \%$ & $31.4 \%$ & $20-39 y$ & $31.4 \%$ & 5.0 & 234 \\
\hline $40-64 y$ & $30.1 \%$ & $31.9 \%$ & $40-64 y$ & $30.9 \%$ & 8.4 & 481 \\
\hline$>65 \mathrm{y}$ & $15.4 \%$ & $20.9 \%$ & $65-199 y$ & $13.4 \%$ & 22.7 & 1140 \\
\hline & $100 \%$ & $100 \%$ & & $100 \%$ & $\begin{array}{c}8.0 \\
\text { mean }\end{array}$ & $\begin{array}{c}404 \\
\text { mean }\end{array}$ \\
\hline
\end{tabular}

* reference: Heide H van der, Tinke J.L. Data en Feiten / Facts and Figures 1999; September 1999; Stichting Farmaceutische Kengetallen (Foundation for Pharmaceutical Statistics). Den Haag (NL) 


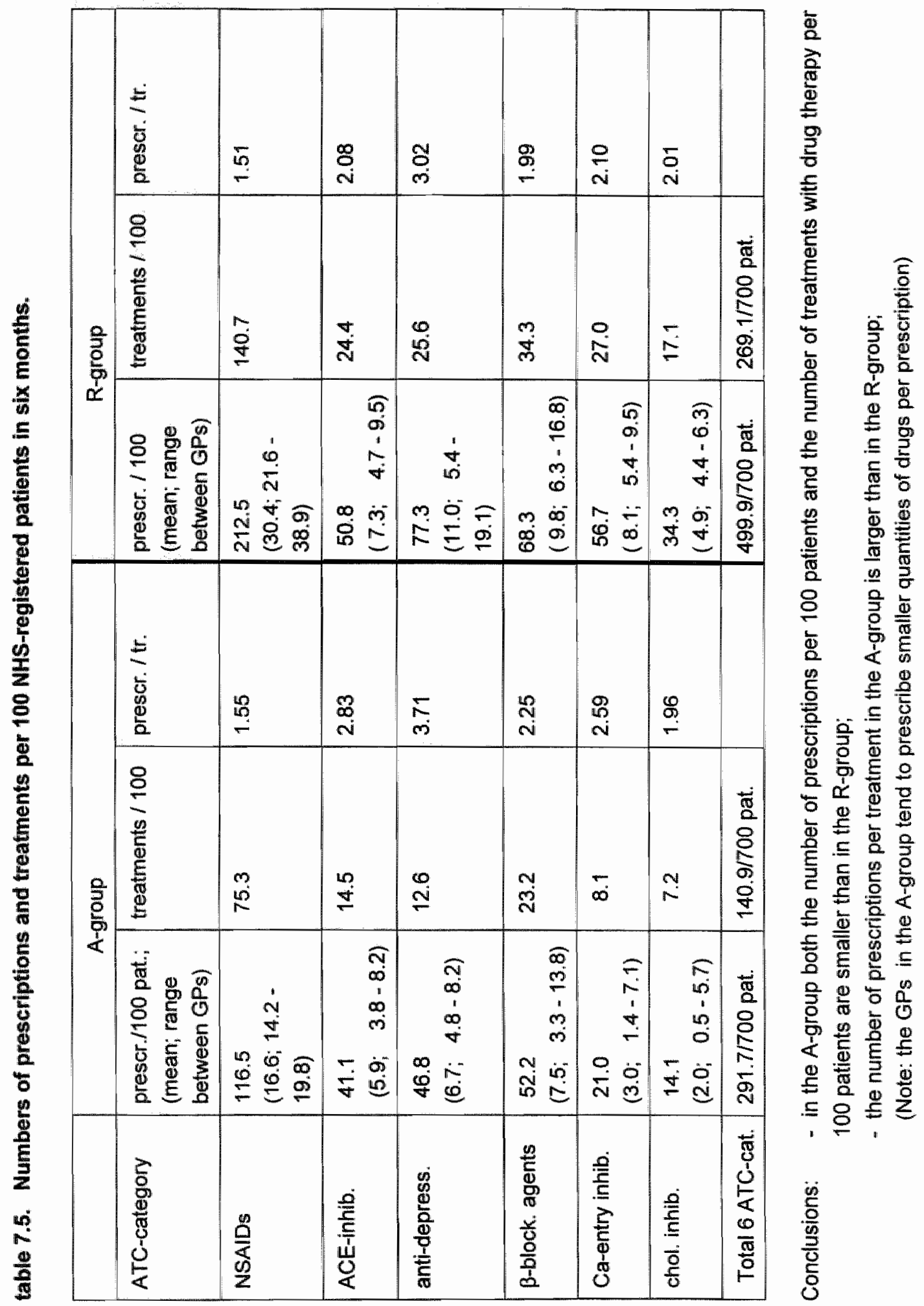



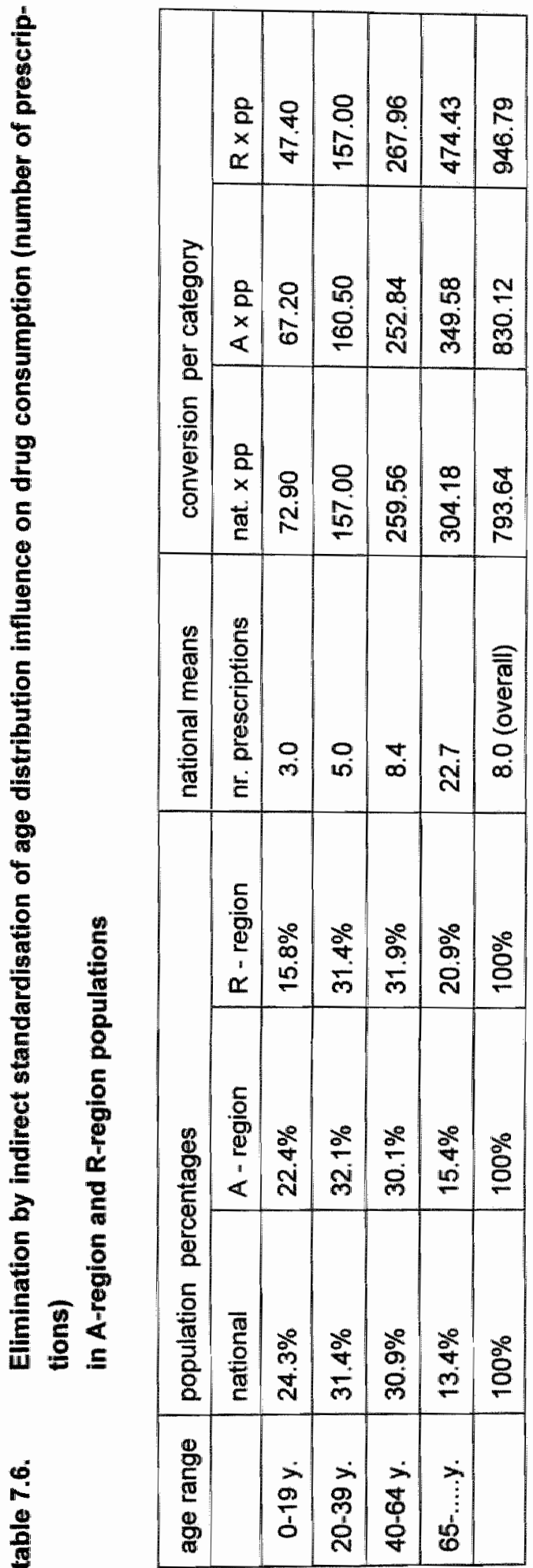

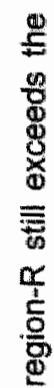

3

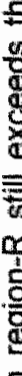

5

을

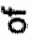

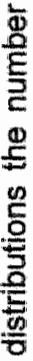

क. 옹

密

ㅇํㅇ 웅

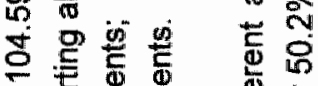

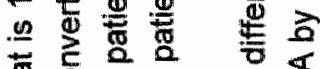

范

$<$ 효

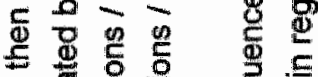

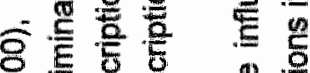

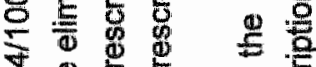

屯 흔

v 50 용

赵舟安

g N

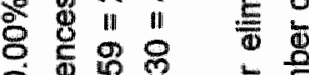

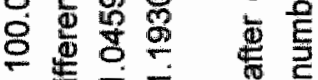

$\frac{\infty}{\pi}=\frac{5}{5}$

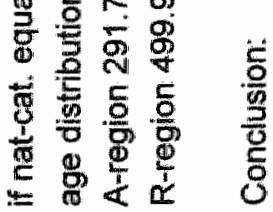




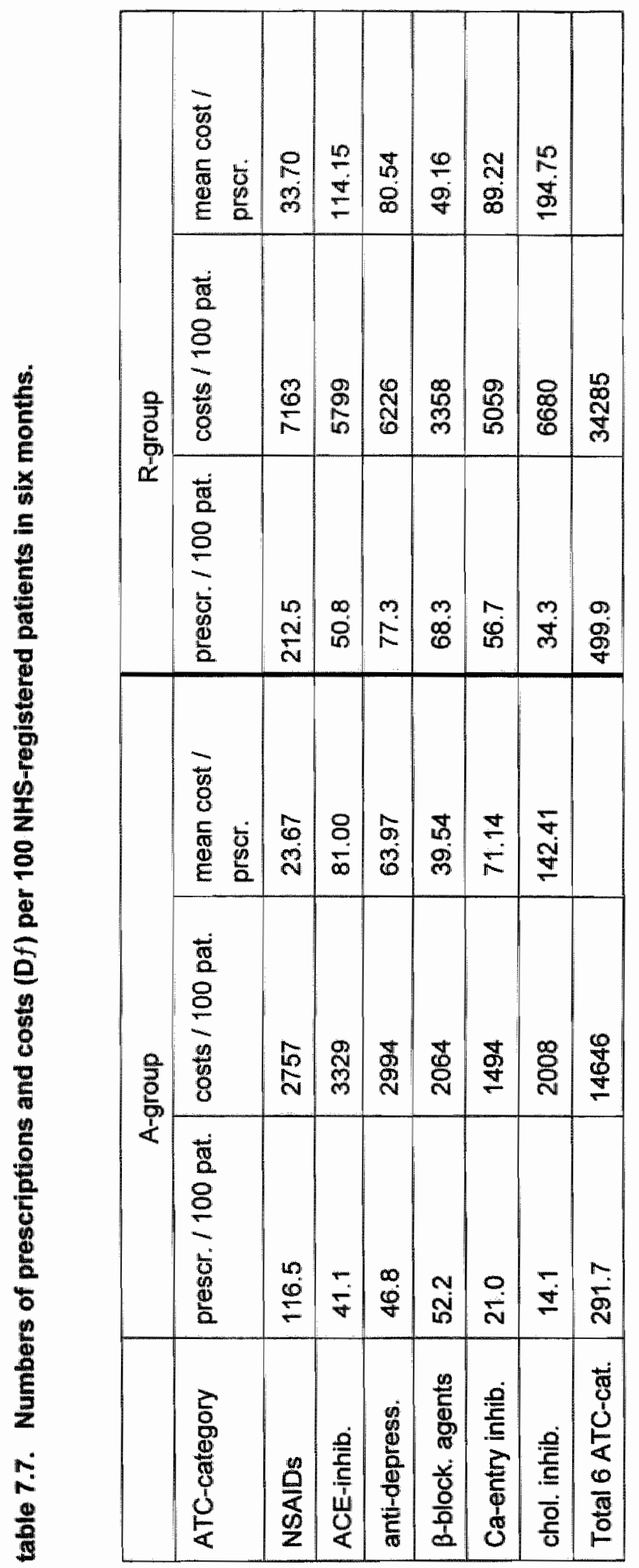




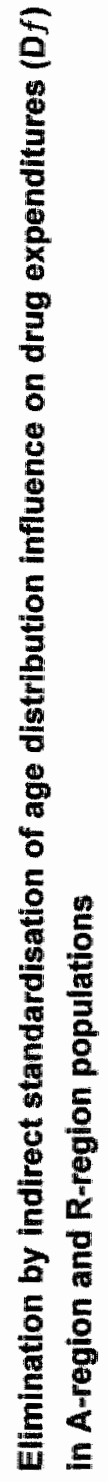

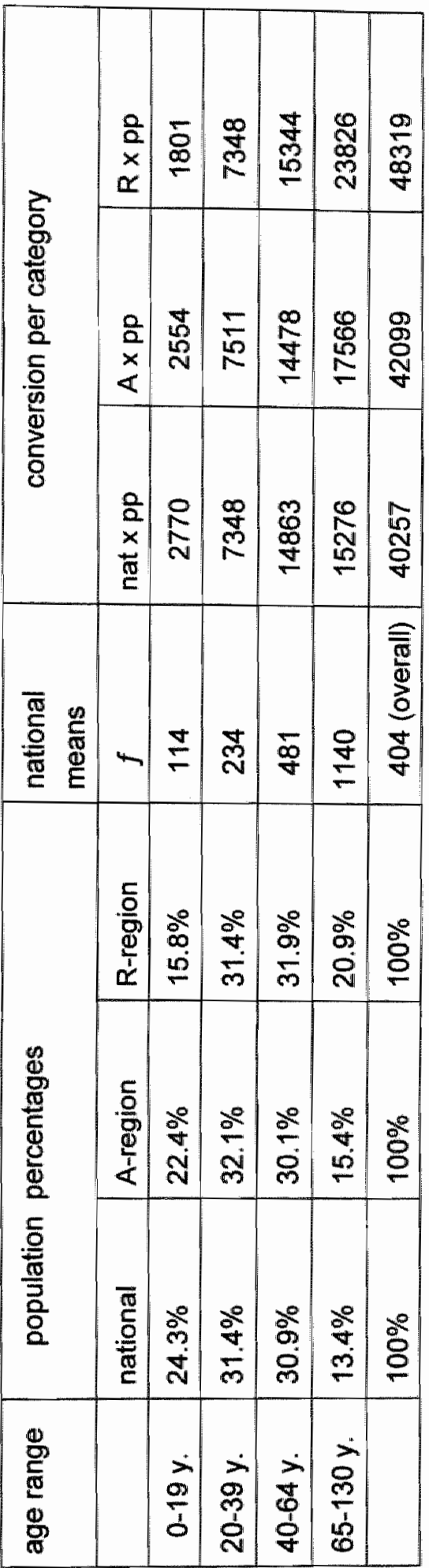

롱

용

$\stackrel{g}{5}$

造

\&

ช

言

옿

$\stackrel{\$}{\mathbb{8}}$

ᄃ

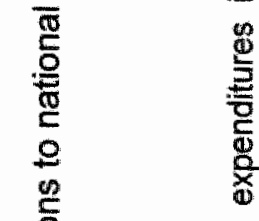

$\because \%$

ले

응

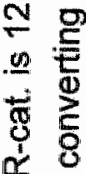

므

कृ

这恋

5. 드

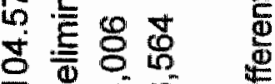

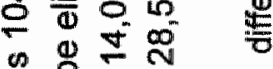

문

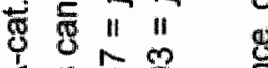

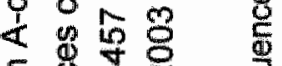

웡요

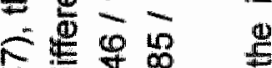

क वे

ชิ 5 ษे प्रे

需京

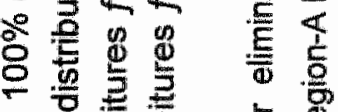

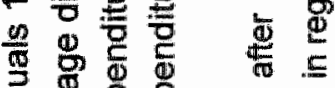

可此文文

苍过

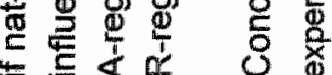


table 7.9. Function and influence of pharmaco-therapeutic audit meetings in two districts

\begin{tabular}{|c|c|c|}
\hline & district $A$ & district $R$ \\
\hline total number of population & 280,000 & 310,000 \\
\hline $\begin{array}{l}\text { Number of participating PTA-groups } \\
\text { - mean number of GPs per group } \\
\text { - mean number of pharmacists per group }\end{array}$ & $\begin{array}{l}34 \\
9 \\
2.9\end{array}$ & $\begin{array}{l}58 \\
8.9 \\
2.5\end{array}$ \\
\hline $\begin{array}{l}\text { Organisation of PTAM in cooperation between * } \\
\text { GPs and pharmacists }\end{array}$ & $93.5 \%$ & $70.7 \%$ \\
\hline $\begin{array}{l}\text { Objectives and aims clearly defined: } \\
\text { - common formulary } \\
\text { - reduction of number of prescriptions } \\
\text { - reduction of simultaneous prescription of dif- } \\
\text { ferent drugs }\end{array}$ & $\begin{array}{l}58.1 \% \\
29.0 \% \\
30.0 \% \\
13.3 \%\end{array}$ & $\begin{array}{l}48.3 \% \\
20.7 \% \\
48.3 \% \\
6.9 \%\end{array}$ \\
\hline $\begin{array}{l}\text { Use of electronic formulary in the district: } \\
\text { - percentage of all GPs } \\
\text { - }<50 \% \text { of PTA-groups } \\
\text { - positive attitude towards use of electronic } \\
\text { formulary }\end{array}$ & $\begin{array}{l}3.2 \% \\
12.9 \% \\
48.0 \%\end{array}$ & $\begin{array}{l}1.8 \% \\
25.0 \% \\
39.6 \%\end{array}$ \\
\hline $\begin{array}{l}\text { Numerical information on prescription data used: ** } \\
\text { - purpose: information on own prescription pol- } \\
\text { icy } \\
\text { - purpose: comparison with colleagues }\end{array}$ & $\begin{array}{l}76.7 \% \\
70.0 \% \\
60.0 \%\end{array}$ & $\begin{array}{l}60.7 \% \\
55.2 \% \\
41.4 \%\end{array}$ \\
\hline
\end{tabular}

* percentage of PTA-groups 
table 7.10. Multiple linear regression analysis with number of prescriptions per 100 subjects per half year period as dependent variable.

\begin{tabular}{|l|l|l|l|l|}
\hline & \multicolumn{2}{|c|}{ model 1 } & \multicolumn{2}{c|}{ model 2 } \\
\hline independent variable & coefficient & $\begin{array}{l}\text { standlard } \\
\text { error }\end{array}$ & coefficient & $\begin{array}{l}\text { standard } \\
\text { error }\end{array}$ \\
\hline GP group $(A=1 ; \mathrm{R}=0)$ & -25.2 & $4.2^{* *}$ & -25.9 & $3.7^{* *}$ \\
\hline $\begin{array}{l}\text { practice size (number of NHS reg- } \\
\text { istered subjects) }\end{array}$ & 0.003 & 0.001 & - & - \\
\hline$\%$ patients $>65$ years of age & 0.7 & $0.3^{*}$ & 0.7 & $0.3^{*}$ \\
\hline
\end{tabular}

$$
\begin{array}{rl}
* & p<0.05 \\
{ }^{* *} p & <0.01
\end{array}
$$


CHAPTER VIII

GENERAL DISCUSSION AND CONCLUSIONS 
Introduction. With the aim to contribute to the development of rational prescription of medicine in general practice we started an investigation into the prescribing behaviour of generall practitioners. In the Netherlands as all over the western world there is a large variety in prescription policy which is dependent on medical education, government measures, the doctor-patient relationship and local or national customs. Not only the diversity of drugs for prescription is substantial but also the attitude of GPs towards pharmacotherapy appears to be different from one region to another. Moreover, the selection process is complicated by the continuous stream of newly developed drugs which become available for prescription. Despite national regulations concerning admission of new drugs, a large variety for selection within many ATC-categories is still maintained. A good survey of all available drugs with adequate knowledge of therapeutic properties and also unwanted side effects appears to be a problem for many physicians. Nevertheless it is expected that they keep up with developments in medicine including pharmacotherapy which unevitably leads to gradually or sometimes even abruptly changing prescriptions.

Through an observational study in a group of seven GPs (designated Reference group) we contributed to a better insight in the prescription behaviour of physicians in general practice. The GPs had been selected for participation on the criterion that they were geographically situated near the central pharmacy and that the patients were for their prescriptions mainly oriented at the central pharmacy. All doctors had their practice in a middle size Dutch town and worked in their practice for many years. Four of them worked independently each in his own practice whilst three others participated in two group practices. Together they were serving a population of 19,000 people, each practice containing between 2500 and 3000 patients. Overall no significant differences between the practices have been observed and this group although consisting of only seven GPs might well be representative for many practices in the Netherlands. No mutual agreements whatsoever on prescription policy had ever been made despite the existence of guidelines for therapy which had been published by the Dutch College of General Practitioners (NHG). The study was performed by collecting and processing all prescriptions of the participating GPs through the computer system of the central pharmacy where all drugs were delivered. Considering the above mentioned issues it was hardly a surprise to find that a large variety of drugs was regularly prescribed. We also observed that consistent prescription behaviour and longitudinal changes in line with medical developments stayed behind modern insights in pharmacotherapy. Prescription under time pressure too often had become a matter of routine which was influ- 
enced by chance information. Experience with new drugs was dependent on 'trial and error" and information on new drugs was mostly obtained from medical representatives of pharmaceutical companies whose advice could be supposed to be influenced by economical motives. The need for objective education was generally felt but for lack of time and opportunity could seldom be fulfilled. Prescription in line with national guidelines (NHG) was only observed to a limited extent. It must be concluded that this too could be improved by better prescription discipline leading to increased rational prescription and avoidance of ill-founded longitudinal changes.

As we supposed that many of the described problems were at least partly due to lack of information and guidance in prescribing we compared the prescription behaviour of the reference group with another group (designated Audit-group) also consisting of seven GPs. In two group practices they provided medical care for a population of 14,000 patients in a semi-rural region. In general the patient population in the A-region was comparable to the R-region with the exception that the proportion of elderly patients in the R-region was slightly higher. A comparison was nevertheless possible as adjustment for age differences could be performed by indirect standardisation.

In contrast with the GPs in the R-group the GPs in the A-group aimed to keep their prescriptions within the scope of a limited common formulary, the A-formulary. This had been composed and is regularly updated in common monthly pharmaco-therapeutic audit meetings of all GPs and the local pharmacists. The A-formulary was based on the professional experience and expertise of all PTAM participants. The NHG-guidelines were included in the discussion and by general agreement partly incorporated in the A-formulary which was installed and ready for use in every GP's computerised practice administration. Although drugs from the formulary were preferably prescribed, necessary deviations were allowed. An important aspect was the commitment of all participants which was stimulated by the monthly feedback consultations in the PTAMs.

Another item in the A-group was the relation with the pharmaceutical industry. In order to effectuate independent prescription it was agreed that none of the GPs received visits from medical representatives but that all contacts were maintained by the pharmacists. The obtained information, filtered by the professional knowledge of the pharmacists, was commented and distributed during the monthly meetings. In this way trial and error policy of the GPs in the prescription of new drugs could be prevented and the prescription spectrum kept limited (155).

Objective comparison. Using easily accessible data from the computerised administration of the central pharmacy we compared the prescription behaviour 
of general practitioners who either prescribed by routine and/or intuition ( $R$ group) or in agreement with a self-composed limited formulary (A-group). It appeared that due to the self-imposed prescription discipline in the A-group the variety of prescribed drugs was substantially smaller than in the reference group. Moreover, the number of prescriptions per 100 patients per year was, even after age adjustment, $15.7 \%$ lower than in the R-group. It could easily be concluded that the compliance with the formulary was largely due to the fact that all GPs were convinced of the quality of the latter. In composing the formulary no industrial influence had been playing a role but the selection of drugs was entirely based on the knowledge of the pharmacists and physicians and the experience of the latter with the selected therapies. Permanent education in the A-group was common practice ans was achieved by compulsory monthly pharmaco-therapeutic audit meetings where all GPs and the local pharmacists participated. Experiences and new developments were then discussed. Information from the industry was passed on and commented by the pharmacists or on invitation by external experts. We observed that this policy gradually changed prescription behaviour towards a limited number of recommended drugs and that experience and expertise of the GPs increased to the benefit of doctors and patients both. Moreover, a not unimportant effect was that the costs for pharmacotherapy in the A-region were substantially lower than in the R-region.

Critical remarks. We are aware that this method of comparison has its limitations. It would be interesting not only to compare the prescription behaviour of the GPs but to include possibly occurring different morbidity patterns in both regions as well. It was regrettable that because of non-identical registration systems accurate data for comparison of morbidity in both regions could not be obtained. As a consequence diagnostic aspects could not be involved in our comparison. We assumed this to be in agreement with the supposition on which the NHG-guidelines for therapy are based, i.e. that all doctors make correct diagnoses to the same extent. Moreover, that no substantially different morbidity patterns were to be expected could be deduced from reasonably similar proportional prescription patterns between the six ATC-categories in both regions. Finally it is undeniable that the method we used to compare the prescription behaviour of (groups of) GPs was based on solid unambiguous data which have been collected over a long period of three and a half year and led to interesting conclusions which may prove their validity in general practice.

Awareness of prescription. Apart from the objective improvements towards more rational prescription policy, it was most interesting to evaluate their own prescription behaviour by interviews with all individual physicians. Looking back on their prescriptions from the passed three and a half year, the GPs in the 
reference group expressed only a limited awareness of their prescribing behaviour. Many influences were mentioned and also subconscious influences could be retrieved. In the audit-group, however, good awareness was observed with all physicians and influences on prescription policy could always be reduced to deliberate policies as agreed in the PTAMs.

Conclusions. From our studies we conclude that the essential principle for improving prescription behaviour towards more rational pharmacotherapy appeared to be the willingness of GPS and pharmacists to cooperate with respect for each others professionality. A limited commonly agreed formulary ready at hand at the doctor's desk is a valuable instrument. Important goals can be reached such as increased experience and expertise of GPs and pharmacists resulting in well defined longitudinal changes in prescription keeping up with modern developments.

After the completion of this thesis the problem still remained and it turned out that the debate will continue and work is there to be done. This thesis may inspire cooperating groups of general practitioners and community pharmacists to go on working together on more rational prescribing habits. As demonstrated this appears to be easily feasible with simple resources and aids. It also intends to contribute to a more suitable, efficient and pleasant cooperation for which adequately structured pharmaco-therapeutic audit meetings (PTAMs) offer ample opportunities. Last but not least this might give both groups, GPs and community pharmacists, more satisfaction in every day work warranting accuracy of prescription and promoting that the doctor's main attention can be returned to the patient where it belongs. 
SUMMARY 
Curiosity which so often lies at the roots of scientific investigations was also the incentive to start the present study on prescription in general practice. Twenty years of experience as a community pharmacist raised the author's fascination for the gap she thought to recognise between the omnipresent positive intention of doctors towards "good prescribing", the ever increasing efforts of the government to urge doctors towards "rational prescribing" and the obvious everyday reality of sub-optimal prescribing habits. As through computerised administration systems the possibility now exists the author decided to study and perhaps to elucidate some aspects of the prescribing of GPs that might be a few reasons for the mentioned gap (chapter I).

Reviewing the available literature many sometimes opposite results of previous studies were found (chapter II). Many items regarding prescription have been mentioned which could be classified in five main categories, i.e. the general behaviour of the physicians, pharmaceutical aspects, the influence of formularies, the influence of professional medical education and information and last but not least the influence of the patients on prescription. Many interventions with varying success have been reported mainly focussing on either improving drug treatment or reducing expenditures for pharmacotherapy. Aspects of improved prescription were increased safety of drugs, less or better known adverse drug reactions, reduced microbial resistance and increased experience and expertise of the prescribing physicians. Repeatedly the influence of prescribing in line with a formulary was reported to be of primary importance. A detailed study on the latter seemed to be justified.

We decided to compare the prescriptions of two groups of GPs (chapter III). A reference-group (R-group) of seven physicians was selected where no mutual agreements on prescription whatsoever existed. Their prescription behaviour was compared with the policy in an audit-group (A-group) of seven other physicians with a successful history of ten years of formulary agreements. In both groups the prescriptions for six ATC-categories (NSAIDs M01A, ACE-inhibitors C09A, antidepressants N06A, beta-blocking agents C07A, calcium channel blocking agents $\mathrm{C} 08 \mathrm{C}$ and cholesterol inhibitors $\mathrm{C} 10 \mathrm{AA}$ ) for the treatment of frequently encountered diseases were collected and studied. The ATC-categories offered in each category sufficient interchangeability of listed drugs to allow the GPs to make individual selections for prescription.

A longitudinal retrospective study over a period of three and a half year concerning prescriptions for drugs from the mentioned categories was planned to check if differences between the two groups in changes and stability over time could be 
made graphically visible. Moreover, the compliance with national guidelines and formulary agreements were judged. Prescriptions were to be collected from the community pharmacy computer, counted and classified. Retrospective interviews with the prescribing GPs in reply to the obtained results could then clarify the underlying (un)aware reasons for the compliance, changes and stability as shown. Again differences between the two groups would have to be compared and judged. Finally aspects of the cost of pharmaceutical aid in both groups would be determined and differences should be judged.

We started studying the longitudinal changes and stability in prescription numbers in an 'unbound prescription' group of general practitioners (chapter $M$. A reference group (R-group) consisting of seven GPs were found in a middle sized town in the Netherlands with an adequate number of prescriptions in each of the six ATC-categories. All prescriptions were processed by one central pharmacy. Retrospective counting and classifying the prescriptions per half year periods produced graphical representations and showed longitudinal changes and stability of prescribing of each GP during three and a half year. The graphical diagrams permitted a rapid and clear insight in the individual drug choice over the study period. It appeared that a wide variety of drugs were chosen by each GP. Numbers of different chemical entities selected for prescription varied from $48-65$ between GPs from a total of 77 available drugs in three and a half year. The mean compliance with the NHG-guidelines, 14 nationally recommended drugs within the ATC-categories in our study, showed large differences between the ATCcategories: from $28 \%$ for antidepressants up to $84 \%$ for cholesterol inhibitors. This means that $16 \%-72 \%$ of prescribed drugs were selected from outside the recommended NHG-guidelines. Moreover, large inter-doctor variations in compliance within the ATC-categaries were abserved eg. $16 \%-55 \%$ for the antidepressants and $25 \%-74 \%$ for the ACE-inhibitors. Coefficients of variation have been calculated for the consecutive half year data representing numerical values for the rate of longitudinal changes. The quality of prescribing, consistent prescription behaviour and/or deliberate changes of selected drugs, could only be assessed by combination of numerical and graphical data. The numerical data as such were helpful to track down "trial and error" prescribing.

In the second part of our study (chapter $V$ we counted and classified the prescriptions of the audit group (A-group) of seven GPs in a semi-rural area in the Netherlands, who had agreed to formulary-bound prescription. In close cooperation with the local pharmacists they had composed the A-formulary, a limited list of 15 drugs from the mentioned six ATC-categories (77 drugs) which they re- 
commended for prescription. The A-formulary contained a number of drugs which were recommended in the NHG-guidelines but some differences were also registered. It was ready at hand in the computer on each doctor's desk and the GPs aimed to prescribe preferably from their electronic A-formulary. A good mean compliance could be expected with the A-formulary and was observed ranging from $60 \%$ for beta-blocking agents to $97 \%$ for calcium channel blocking agents. The individual compliance showed some inter-doctor variation, e.g. $54 \%$ - $79 \%$ for antidepressants and $68 \%-100 \%$ for cholesterol inhibitors. Processing the collected prescription data as those from the R-group it appeared that although prescription of the 15 drugs from the formulary had preference, nevertheless all together 31 till 42 different chemical entities had at least once been selected for prescription during three and a half year. Graphical diagrams, however, displayed generally consistent prescription behaviour and some deliberate changes of drug selection. Rapidly changing selection pointing at 'trial and error' policy was not detected. Again, the combination of graphical diagrams with coefficients of variation provided insight in the quality of prescription.

Comparing the data from the A-group and the R-group we made the following observations:

- the variety of different chemical entities prescribed in six reviewed ATCcategories in our study period was greater in the R-group, than in the Agroup;

- the compliance with the agreed formulary in the A-group was better than the compliance with national guidelines in the R-group;

- the compliance with the agreed formulary in the A-group gradually increased during the period of our study whilst on the contrary the compliance of the R-group with national guidelines decreased;

- several rapidly increasing and afterwards decreasing numbers of prescriptions for nationally not recommended drugs pointing at impulsive prescription or "trial and error" policy were detected in the R-group, and not in the Agroup.

- coefficients of variation were generally larger in the $R$-group than in the $A$ group indicating a higher rate of changing prescription behaviour.

The next part of the study was certainly not the least interesting one (chapter VI). After having processed and evaluated the collected data, we confronted all GPs in both groups with the obtained results and showed them each the figures and the graphical presentations concerning their own prescriptions from the passed three and a half year. They were then asked to participate in a structured retrospective interview on their prescription behaviour to which they all agreed. The results of the 
interviews could be summarised as follows:

- All GPs appeared to be highly interested in the graphical presentations of their own prescription patterns;

- The GPS in the A-group were generally well aware of their prescribing patterns, whilst the GPs in the R-group showed much lack of awareness;

- The changes and stabilities in the prescription patterns of the GPs of the Agroup were generally meant to keep pace with the formulary agreements, while changes in the patterns of the GPs of the R-group generally represented 'trial and error' experiences, sometimes on request of pharmaceutical companies;

- The GPs of the R-group were familiar with the national guidelines but as a rule did not discuss them in their pams, while in the A-group the national guidelines were the basis of the monthly discussions in combination with updating the A-formulary;

- The GPs of the A-group were aware of most of the influences on their prescribing habits such as safety and effectiveness of the prescribed drugs, side effects, dosage forms, own experiences and routine discussions in their monthly pams. The GPs of the R-group felt they had to deal with these influences every time a prescription was written out and they could not rely on their own routine;

- The GPs in the A-group felt that they had reliable knowledge about the drugs and the reasons for listing these in the formulary which they could explain to patients and hospital consultants, even in the case of rare severe adverse reactions;

- The GPs in the R-group had to rely more on individual study of professional literature than the GPs in the A-group whilst the knowledge of the latter about (new) drugs was largely taken from the monthly PAM.; the GPs in the R-group consulted medical representatives from the industry on a regular basis, whilst in the A-group the pharmacists received the visits of MRs and passed their information on in the monthly PTAMs; the GPs or the A-group felt that the social part of the PTAMs was an important part of their professional activities; costs were never important items for discussion in both groups and all GPs were happy about that.

In order to compare expenditures (chapter VII) for pharmacotherapy between the R-region and the A-region, we studied numbers of prescriptions and treatments and related costs in the first six months of 1999 . The data were kindly provided by the regional health insurance companies for statutorily insured patients after 
obtained permission of the GPs in our study. Smaller numbers of prescriptions and treatments per 100 patients were registered in the A-group compared with the Rgroup. To some extent this might be due to a larger proportion of elderly patients in the R-region but also after adjustment for age differences smaller figures for the A-group remained. We suggest that the reluctant attitude towards prescribing as we found earlier in the A-group might have affected these numbers. However, the GPs in the A-group wrote out a larger number of prescriptions per treatment. This could be explained by the fact that they deliberately kept the quantity of tablets, suppositories, drops, etc. per prescription low for medical and waste-lowering reasons. In spite of increased pharmacy fees as a result of this conscious prescribing policy, the total expenditures in the A-group also after age adjustment remained substantially lower than in the R-group.

It could be concluded (chapter VIII) that the prescription patterns of general practitioners who worked without clearly defined guidelines for prescription of drugs (R-group) showed more and larger longitudinal changes than have been registered with prescription patterns following a limited formulary (A-group). Some of the changes in prescribing patterns in the R-group could be described as "trial and error' behaviour which was largely prevented by formulary agreements in the A-group.

The physicians in the R-group also reported little retrospective awareness of their own prescribing habits which sometimes seemed to be influenced by the capricious competition of numerous influences. In their monthly PTAMs the GPs in the A-group discussed and evaluated such influences which were also reduced by restricted prescription in line with their formulary.

For all GPs the compliance with national guidelines for prescription was relatively high in ATC-groups with generally clear diagnoses or in cases of evident efficacy or risks such as pain or hypertension of the selected drugs. A low compliance was registered when the diagnosis was less certain (e.g. depression) or when the introduction of new drugs caused difficulties in everyday practice (e.g. cholesterolinhibitors). This was true for the prescription behaviour of GPs in both groups.

Favourable influences of formulary-bound prescription policy have been observed such as a reduced number of prescriptions and lower costs for drug therapy but perhaps more important were the increased awareness of prescribing of doctors in the A-group and the concomitant increase of personal experience and expertise resulting in a reluctant and conscious attitude towards prescribing. Most valuable were the regular structured PTAMs. The GPs were very happy with the electronic formulary that caused prescription from a limited number of drugs as a result of the PTAMs. The ultimate common goal was to promote rational prescription behaviour 
and selection of recommended drugs. All participants in the A-group expressed their satisfaction with the PTAMs which were based on mutual respect and willingness to cooperate between local physicians and community pharmacists. This structure had deliberately been chosen and actively maintained and it had succesfully overcome the test of some strong social threats. 
SAMENVATTING 
Zoals zo vaak was ook voor dit onderzoek naar het voorschrijfgedrag in de huisartsenpraktijk nieuwsgierigheid de drijfveer. In de loop van twintig jaar werken als openbaar apotheker raakte de auteur van dit proefschrift geboeid door de kloof die ze meende te kunnen ontdekken tussen de alomtegenwoordige positieve houding van artsen ten opzichte van "goed voorschrijfgedrag", de steeds toenemende druk die van overheidswege werd uitgeoefend op artsen om doelmatig voor te schrijven en de praktijk van alle dag, waar uit het nakijken van de dagelijkse stapel recepten bleek, dat het voorschrijfgedrag ver van het ideaal stond. Door de mogelijkheden, die de hedendaagse geautomatiseerde receptverwerking biedt, besloot de auteur een aantal aspecten van het voorschrijven door huisartsen te bestuderen om zodoende misschien een paar redenen te ontdekken voor het bestaan van de genoemde kloof (hoofdstuk I).

In de literatuur vonden we vele, soms tegenstrijdige, resultaten van onderzoeken (hoofdstuk II). Er werden vele verschillende onderwerpen genoemd die het voorschrijven beïnvloeden. We konden ze in vijf categorieên indelen: algemene kenmerken van huisartsen als persoon, farmaceutische aspecten, de invloed van formularia, de invloed van (na)scholing van en informatie aan artsen en, niet minder belangrijk, de invloed van patiënten op het voorschrijfgedrag. Er zijn vele interventies gepleegd, met wisselend succes, waarbij de nadruk vaak werd gelegd op verbetering van de behandeling met behulp van geneesmiddelen of op een kostenverlaging van de farmaceutische hulp. Verbeteren van het voorschrijfged rag had vaak te maken met streven naar meer veiligheid bij geneesmiddelen, minder bijwerkingen of een grotere kennis ervan, het voorkomen van bacteriële resistentievorming en streven naar meer ervaring en deskundigheid van artsen op het gebied van voorschrijven. Veelvuldig werd er gerapporteerd over het belang van formulariumgebruik als middel om het voorschrijfgedrag te beïnvloeden. Een gedetailleerd onderzoek naar formulariumgebruik leek gerechtvaardigd.

We besloten de voorschriften van twee groepen huisartsen te vergelijken (hoofdstuk III). We zochten en vonden een referentiegroep (R-groep) van zeven huisartsen die nog nooit enige afspraak hadden gemaakt over voorschriffgedrag. Hun manier van voorschrijven hebben we vergeleken met die van een auditgroep (A-groep) van zeven andere huisartsen met formulariumafspraken die al tien jaar een succes bleken te zijn. In beide groepen hebben we de voorschriften voor 77 geneesmiddelen in zes klassen (ATC-klassen: NSAIDs M01A, ACE-remmers C09A, antidepressiva N06A, betablokkers C07A, calciumantagonisten C08C en cholesterolverlagers $C 10 A A$ ) voor de behandeling van aan aantal veel voorkomende ziekten geteld en bestudeerd. Binnen de verschillende ATC-klassen bestonden 
voldoende mogelijkheden am van de onderlinge uitwisselbaarheid van geneesmiddelen binnen een klasse gebruik te maken, zodat de huisartsen de mogelijkheid hadden om hun eigen selectie voor hun voorschriften te kiezen.

Een plan voor een longitudinaal retrospectief onderzoek over een periode van drie en een half jaar aangaande de voorschriften voor geneesmiddelen uit de genoemde klassen werd ontworpen om indien mogelijk de verschillen tussen de twee groepen huisartsen ${ }_{*}$ voor wat betreft de veranderingen en de stabiliteit in voorschrijven in het verloop van de tijd, in grafieken zichtbaar te kunnen maken. Verder wilden we de mate van overeenstemming van de voorschriften met de NHG-standaarden en de formularium-afspraken (compliantie) toetsen. We zouden de voorschriften uit de computer van de openbare apotheek verzamelen, tellen en indelen. Daarna zouden terugblikkende interviews met de huisartsen als commentaar op de gevonden grafieken de onderliggende (on)bewuste motieven voor de compliantie, de veranderingen en de stabiliteit kunnen ophelderen. De gegevens uit deze interviews zouden we ook onderzoeken en beoordelen op verschillen en overeenkomsten tussen de beide groepen. Tenslotte zouden we verschillen tussen de beide groepen in kosten voor de farmaceutische hulp binnen de gekozen ATC-klassen moeten vergelijken.

We begonnen met het onderzoek naar de longitudinale veranderingen en stabiliteit in de voorschrijfpatronen van een groep huisartsen die 'vrij' waren in het voorschrijven (hoofdstuk IM). We vonden een referentie groep (R-groep) bereid bestaande uit zeven huisartsen in een middelgrote stad in Nederland met een voldoende aantal voorschriften in elk van de ATC-klassen. Alle voorschriften werden verwerkt door een openbare apotheek. Het achteraf tellen en indelen van de voorschriften per half jaar leverde een grafische weergave op, die longitudinale veranderingen en stabiliteit liet zien van elke huisarts over drie en een half jaar. De grafieken verschaften snel een helder beeld van de individuele geneesmiddelenkeuze over de onderzoeksperiode. Het bleek, dat elke huisarts gebruik maakte van een groot aantal verschillende geneesmiddelen. Het aantal verschillende chemische entiteiten dat werd voorgeschreven varieerde tussen de huisartsen. In de periode van drie en een half jaar werden 48 tot 65 van een totaal van 77 beschikbare geneesmiddelen voorgeschreven. De gemiddelde compliantie met de NHG-standaarden, 14 landelijk aanbevolen geneesmiddelen binnen de ATCklassen in ons onderzoek, vertoonde grote verschillen tussen de ATC-klassen: van $28 \%$ voor de antidepressiva tot $84 \%$ voor de cholesterolremmers. Dit betekent, dat in $16 \%-72 \%$ de farmaco-therapeutische aanbevelingen van de staandaarden niet werden gevolgd. Verder werden er ook grote verschillen in compliantie tussen de 
huisartsen gevonden binnen de ATC-klassen, b.v. $16 \%$ - $55 \%$ voor de antidepressiva en $25 \%-74 \%$ voor de ACE-remmers. We hebben variatiecoefficienten berekend over de opeenvolgende halve jaren om een getalsmatige uitdrukking te vinden voor de mate van veranderingen in de tijd. De combinatie van de getallen en de grafieken gaf echter de beste mogelijkheden voor het beoordelen van de kwaliteit van voorschrijven, al dan niet consistent gedrag en/of welbewuste veranderingen in de keuze van de geneesmiddelen. De variatiecoëfficient bleek een goed hulpmiddel om voorbeelden van experimenteel voorschrijven op te sporen.

In het tweede deel van ons onderzoek (hoofdstuk $V$ ) hebben we de voorschriften van de audit groep (A-groep) geteld en ingedeeld. Deze groep bestond uit zeven huisartsen in een verstedelijkte plattelandsgemeente in Nederland. Zij hadden afspraken gemaakt over voorschrijven op basis van een formularium. In nauwe samenwerking met de plaatselijke openbare apothekers hadden ze het $\mathrm{A}$ formularium samengesteld. Binnen de ATC-klassen in ons onderzoek waren er 15 van de 77 geneesmiddelen aangewezen als eerst of tweede formularium-keuze. Een aantal formularium-keuzes waren in overeensternming met de keuzes in de NHG-standaarden, maar hier en daar verschilden de aanbevelingen. Het formularium was in electronische vorm direct te gebruiken in de computer op het bureau van de huisarts en de huisartsen hadden afgesproken om hun keuze voornamelijk te beperken tot de formularium-afspraken. De compliantie was, zoals te verwachten, behoorlijk groot en varieerde van $60 \%$ voor de betablokkers tot $97 \%$ voor de calciumantagonisten. De individuele compliantie vertoonde ook hier wat verschillen, b.v. $54 \%-79 \%$ voor de antidepressiva en $68 \%-100 \%$ voor de cholesterolremmers. Nadat de gegevens op dezelfde manier als voor de R-groep waren verwerkt, bleek, dat er ondanks de voorkeur voor 15 formularium-middelen toch 31-42 verschillende chemische entiteiten tenminste 1 keer waren voorgeschreven in de loop van de drie en een half jaar. De grafieken lieten echter een patroon zien, dat over het algemeen consistent genoemd kon worden met hier een daar een geleidelijke verandering in de richting van de formularium-middelen. Snelle veranderingen, zoals ze kenmerkend zijn voor het experimentele voorschrijven, werden in de grafieken van de A-groep niet aangetroffen. Ook hier gaven de grafieken in combinatie met de variatiecoëfficienten een goed beeld van de kwaliteit van voorschrijven.

Als we de gegevens van de A-groep en de R-groep vergelijken, constateren we het volgende:

- het aantal verschillende chemische entiteiten dat werd voorgeschreven in 
de zes ATC-klassen van ons onderzoek was groter in de R-groep dan in de A-groep;

- de compliantie met de formularium-afspraken in de A-groep was groter dan de compliantie van de R-groep met de NHG-standaarden;

- de compliantie met de formularium-afspraken in de A-groep nam over de onderzoeksperiode toe, terwijl daarentegen de compliantie van de R-groep met de NHG-standaarden afnam;

- meerdere keren zagen we in de R-groep, maar niet in de A-groep, een snelle toename, gevolgd door een snelle afname van het aantal voorschriften voor geneesmiddelen, die landelijk geen voorkeur genieten, wijzend op een impulsief experimenteel voorschrijfgedrag;

- de variatiecoëfficienten waren in de R-groep over het algemeen groter dan in de A-groep, hetgeen wijst op een hogere veranderingsgraad in de voorschrijfpatronen in de R-groep.

Het volgende deel van ons onderzoek was bes list niet het minst interessante deel (hoofdstuk VI). Nadat we de gegevens hadden verwerkt en geëvalueerd, confronteerden we de huisartsen met de getallen en de grafische afbeeldingen van hun eigen voorschrijfpatronen over de afgelopen drie en een half jaar. We vroegen hun medewerking aan een gestructureerd retrospectief gesprek over hun voorschrijfgedrag en allen werkten mee. De resultaten van de interviews kunnen we als volgt samenvatten:

- alle huisartsen waren erg geïnteresseerd in de grafieken van hun eigen voorschrijfpatronen;

- de huisartsen in de A-groep waren zich in het algemeen goed bewust van hun eigen voorschrijfgedrag, terwijl dat bij de huisartsen in de R-groep minder het geval was;

- de veranderingen en de stabiliteit in de voorschrijfpatronen van de A-groep waren over het algemeen opzettelijk nagestreefd om de formulariumafspraken te volgen, terwijl de veranderingen in de patronen van de $\mathrm{R}$ groep vaak experimenteel voorschrijven behelsden, soms op verzoek van de farmaceutische industrie:

- de huisartsen in de R-groep kenden het bestaan en soms de inhoud van de NHG-standaarden, maar in de regel werden deze niet in het FTO besproken, terwijl de NHG-standaarden bij elke formulariumwijziging in de A-groep het uitgangspunt van de discussie waren;

- de huisartsen in de A-groep waren zich bewust van de meeste verschillende onderwerpen die van invloed konden zijn op hun voorschrijfgedrag, b.v. veiligheid en effectiviteit van de voorgeschreven geneesmiddelen, 
bijwerkingen, doseervormen, eigen ervaringen en routine; dit waren onderwerpen die in de FTO's een vast onderdeel vormden van de discussie. De huisartsen van de R-groep moesten al deze aspecten in beschouwing nemen als ze bij het voorschrijven niet op hun eigen routine konden terugvallen;

- de huisartsen in de A-groep vonden, dat ze voldoende wisten over "hun" geneesmiddelen en de redenen waarom ze in het formularium waren opgenomen en dat ze dat goed konden uitleggen aan patiënten of specialisten, zelfs als zich bij uitzondering ernstige bijwerkingen voordeden; de huisartsen in de R-groep besteedden noodzakelijkerwijs meer tijd aan zelfstudie van de vakliteratuur dan de huisartsen in de A-groep, die hun geneesmiddelen-kennis voornamelijk aangereikt kregen door de apothekers op het FTO;

- de huisartsen in de R-groep ontvingen regelmatig artsenbezoekers van de farmaceutische industrie, terwijl in de A-groep de apothekers de artsenbezoekers ontvingen en hun informatie beoordeelden en doorgaven aan de huisartsen op het FTO;

- de huisartsen in de A-groep vonden, dat het sociale aspect van de FTOs belangrijk was voor hun beroepsuitoefening;

in beide groepen waren de kosten nooit een belangrijk onderwerp van gesprek in het FTO en allen waren daar blij mee.

We hebben de aantallen voorschriften, de aantallen behandelingen en de daaraan gekoppelde kosten in beide groepen bestudeerd om de uitgaven voor de farmaceutische hulp binnen de zes ATC-klassen te vergelijken over het eerste half jaar van 1999 (hoofdstuk VII). De regionale zorgverzekeraar was zo vriendelijk om ons, met toestemming van de betrokken huisartsen, de gegevens te sturen over de ziekenfondspatiènten van de praktijken in ons onderzoek. In vergelijking met de $R$-groep vonden we lagere aantallen voorschriften en behandelingen per 100 patiënten in de A-groep. Het in verhouding grotere aantal ouderen in de R-regio zou dat deels kunnen verklaren, maar ook na correctie voor de verschillen in leeftijdsopbouw, bleven de aantallen in de A-groep lager. We veronderstellen, dat de terughoudende houding ten opzichte van voorschrijven, zoals we die eerder in de A-groep aantoonden, van invloed is op deze aantallen. De huisartsen in de Agroep schreven echter wel een groter aantal recepten per behandeling uit. Dit zou verklaard kunnen worden door het feit, dat zij opzettelijk kleinere aantallen tabletten, zetpillen, druppels, enz. op het recept voorschrijven om medische redenen en om retour gebrachte geneesmiddelen zoveel mogelijk te voorkomen. Ondanks een groter aantal regelvergoedingen voor de apotheek, als gevolg van 
voorzichtig voorschrijven, waren de uitgaven in de A-groep, ook na correctie voor de leeftijdsopbouw van de patièntenpopulatie, aanzienlijk lager dan in de R-groep.

Tenslotte (hoofdstuk VII) hebben we kunnen zien, dat de prescriptiepatronen van huisartsen die werken zonder duidelijke richtlijnen voor het voorschrijven van geneesmiddelen (R-groep) meer en grotere longitudinale veranderingen laten zien dan de prescriptiepatronen van huisartsen die werken volgens formulariumafspraken (A-groep). Sommige veranderingen in de R-groep konden worden beschreven als experimenteel voorschrijfgedrag, hetgeen grotendeels werd vermeden door het formulariumgebruik in de A-groep.

De huisartsen in de R-groep gaven aan zich weinig bewust te zijn van hun eigen voorschrijfgedrag, waarin zich af en toe de grilligheid van de samenloop en de tegenstrijdigheden van de verschillende invloeden aftekende. Deze invloeden werden in de FTOs van de A-groep besproken en geëvalueerd en door het formularium grotendeels uitgeschakeld.

De compliantie met de NHG-standaarden was bij alle huisartsen relatief groot indien de bijbehorende diagnoses helder waren of als er overtuigende werkzaamheid van de geneesmiddelen of duidelijke risico's van de ziekte in het spel waren, zoals bij pijn of hoge bloeddruk. We vonden een kleine compliantie als de diagnose minder zeker was (b.v. depressie) of als er sprake was van dagelijkse verwarring door de introductie van nieuwe geneesmiddelen (b.v. de cholesterol-remmers). Dit bleek in beide groepen het gevall.

Formularium-gebonden voorschrijven heeft gunstige gevolgen zoals een lager aantal voorschriften en lagere kosten voor de behandeling met geneesmiddelen, maar, wat misschien nog belangrijker is, de huisartsen in de A-groep waren zich meer bewust van hun voorschrijfgedrag en tegelijkertijd verkregen ze meer inzicht in hun eigen ervaringen en vergrootten ze hun eigen deskundigheid, hetgeen weer een terughoudender en voorzichtiger houding ten opzichte van voorschrijven in het algemeen met zich mee bracht. Dit werd voornamelijk mogelijk door een regelmatig en gestructureerd FTO. De huisartsen in de A-groep waren erg gelukkig met hun electronisch formularium en het voorschrijven van een beperkt aantal geneesmiddelen als gevolg van het FTO. Het uiteindelijke doel was verstandig voorschrijven van een eerste of tweede keuze middel. Alle huisartsen van de Agroep uitten zonder uitzondering hun tevredenheid met het FTO, dat gebaseerd was op wederzijds respect en de bereidwilligheid van artsen en apothekers om samen te werken. Deze structuur was opzettelijk gekozen, werd actief onderhouden en bleek grote maatschappelijke bedreigingen met succes te kunnen doorstaan. 


\section{Dankwoord.}

Onderzoeken en schrijven doet men het beste niet alleen. Dat was bij dit proefschrift dan ook gelukkig niet het geval. Eerst was er André Knottnerus, die in de loop van 1996 door mij benaderd werd met de eerste Excel-grafiekjes over de NSAIDs. Zijn niet aflatend enthousiasme, razend snelle inzicht, opbouwende kritiek en efficiente begeleiding hebben vanaf de eerste ontmoeting het onderzoek in gang gehouden. Vervolgens kwam Paul Brombacher, die met zijn grote wetenschappelijke ervaring, enorme wijsheid "constante regelmaat en geduld het onderzoek en het schrijven een doorslaggevende impuls gaf. Met André en Paul heb ik een buitengewoon prettige tijd gehad, die zich kenmerkte door warmte in een open sfeer, waar elke gedachte geuit kon worden en ondanks de vreugde van de voltooiing van het proefschrift, voel ik spijt, dat deze tijd voorbij is.

Verder zijn er de huisartsen van de R-groep, die ik anoniem zal laten, maar niet ongenoemd. Ondanks het feit, dat ze er in dit boek "slecht" vanaf komen, ben ik er vast van overtuigd, dat zij uitstekende huisartsen zijn, die hun werk met overtuiging, kennis van zaken en grote toewijding doen. Naar mijn mening vertegenwoordigen zij met hun ijver, inzet en kennis de overgrote meerderheid van de Nederlandse huisartsen. Zonder hun openhartige medewerking zou het belang van dit onderzoek nihil zijn. Ik bedank hun allen hartelijk voor de moed en het vertrouwen waarmee ze met mij dit onderzoek zijn ingegaan.

Voor de huisartsen van de A-groep bleek er achteraf in dit boek een heldenrol te zijn weggelegd. Naast de gewonnen arbeidsvreugde is dit een welverdiend loon voor vele jaren van noeste arbeid in de rotsvaste overtuiging, dat de hiervoor beschreven manier van werken een juiste was. Het getuigt van visie en liefde voor het vak, dat de grondslagen van het Astense overleg al in 1980 werden gelegd, toen nog niemand van FTO had gehoord. Vooraf stond de rolverdeling binnen dit boek echter volstrekt niet vast en ook aan hun dus mijn hartelijke dank voor hun aller moed en vertrouwen.

De apothekers van de beide groepen hebben hun apotheken, hun computers en een deel van hun tijd aan mij beschikbaar gesteld. Gert Jan Hooyman, Evelyn Vencken en de anonieme apothekers, heel hartelijk bedankt voor jullie gastvrijheid en de bereidwilligheid om mij telkens weer te helpen met talloze vragen.

De cijfers van de regionale zorgverzekeraar $C Z$ werden mij ter beschikking gesteld door de medewerking van mevr. B.Severens en mevr. A.Loman. Hun beiden dank 
ik hartelijk voor hun nauwkeurigheid en ijver, en de vriendelijke beantwoording van mijn vragen.

Voor een vergelijking van de populaties van de beide patiëntengroepen heb ik de resultaten van enquêtes opgevraagd en gekregen van GGD-en in Limburg en Zuid-Oost Brabant. Samen kwamen wij tot de conclusie, dat vergelijking slechts beperkt mogelijk was, hetgeen leidde tot stelling nr. 3. Ik bedank hen voor hun bereidwilligheid tot inlichtingen, medewerking en uitleg.

De assistenten, bezorger en de collega-apothekers van Theriak Apotheek de Hesselle wil ik bedanken voor het feit, dat ze me de tijd hebben gelaten om me bezig te houden met dit onderzoek. In willekeurige volgorde: Karel Fox, Kitty Gril, Itie Josten, Gerrie Fouwels, Mirjam Benders, Annick Peccholt, Antoinette van Geenen, Hilda Heinen, Evert Donk, Pauline Leenaers, jullie allemaal wil ik heel hartelijk bedanken voor de fijne manier waarop we hebben samengewerkt en de hartelijke manier waarop jullie me in het begin van dit jaar hebben laten gaan.

Mijn familie en alle vrienden en vriendinnen bedank ik voor het geduld en de beleefdheid waarmee ze bij tijd en wijle mijn onattentheid, mijn gebrek aan belangstelling en mijn afwezigheid hebben verdragen. $k$ beloof plechtig beterschap.

Tenslotte rest mij de belangrijkste personen te bedanken die, allen op hun eigen manier en op hun eigen tijd door hun onmiddellijke nabijheid, met mijn leven vervlochten zijn. In de eerste plaats het gezin waar ik werd geboren: pappa( $\boldsymbol{\dagger})$, mamma, Martje en Janneke. Samen met jullie is alles begonnen en uiteraard is olko dag van mijn lovon, on duc aok hot wolelagon van dit onderzook, gokleurd on gedragen vanuit dat eerste begin, waar ik erg dankbaar voor ben.

In de tweede plaats het gezin waar ik ben terecht gekomen: Jo, Marieke, Paul en Joep. Ik ben heel erg blij met jullie liefde en de unieke vriendschap die er tussen ons bestaat.

Ik bedank heel speciaal Jo voor het respect dat hij heeft gehad voor mijn keuze om dit onderzoek te doen en het grote enthousiasme waarmee hij mijn nieuwe werkzaamheden heeft gesteund, en dat, terwijl we een jaar of twintig geleden met heel andere plannen waren begonnen.

Luc Peeters. 


\section{Currĭculum vitae.}

L.M. (Luc) Peeters-Udding werd op 23 mei 1952 geboren te Assen (Drenthe). $\mathrm{Na}$ het behalen van het eindexamen Gymnasium $\beta$ in 1971 aan de Winschoter Scholengemeenschap, begon zij haar studie Farmacie aan de Rijksuniversiteit te Groningen.

Vanaf 1973 was zij tevens gedurende drie jaar part time werkzaam als student(hoofd)-assistent voor het practicum Kwantitatieve Analytische Chemie II onder prof.dr.J.S.Faber.

In 1978 legde zij het doctoraal examen in de farmacie af en in 1979 behaalde zij het apothekers-diploma. In hetzelfde jaar werd zij tweede apotheker in Heerlen en Simpelveld. In 1980 werd zij gevestigd apotheker in Apotheek de Hesselle te Heerlen en bleef werkzaam in deze functie tot 1 april 2000. Gedurende (een deel van) deze periode was zij FTO-apotheker in drie verschillende FTO-groepen in Heerlen en Maastricht. In 1991 maakte ze deel uit van de groep van drie oprichters van een samenwerkingsverband van apothekers, Theriak.

Zij was gedurende zeven jaar lid van de Commissie van Redactie van het Pharmaceutisch Weekblad.

$\mathrm{Z}_{\mathrm{ij}}$ is als gast-docent verbonden aan de Huisartsen-opleiding Universiteit Maastricht voor de lessen aan HAIO's: Farmacotherapie als onderdeel van de basisvorming en Farmacotherapie bij ouderen. 